Portland State University

PDXScholar

$1-1-1976$

\title{
H. S. Chamberlain and the Bayreuth "Kulturkreis": a study in ideology
}

David George Otness

Portland State University

Follow this and additional works at: https://pdxscholar.library.pdx.edu/open_access_etds

\section{Let us know how access to this document benefits you.}

\section{Recommended Citation}

Otness, David George, "H. S. Chamberlain and the Bayreuth "Kulturkreis": a study in ideology" (1976). Dissertations and Theses. Paper 842.

https://doi.org/10.15760/etd.842

This Thesis is brought to you for free and open access. It has been accepted for inclusion in Dissertations and Theses by an authorized administrator of PDXScholar. Please contact us if we can make this document more accessible: pdxscholar@pdx.edu. 
H. S. CHAMBERLAIN AND THE BAYREUTH KUITIURKREIS: A STUDY IN TDEOLOGY by
DAVID GEORGE OTNESS

A thesis submitted in partial fulfillment of the requirements for the degree of

MASTER OF ARTS

in

HISTORY

Portland State University

1976 
AN ABSTRACT OF THE THESIS OF David George Otness for the Master of Arts In History presented November 24, 1976.

THtle: H. S. Chamberlain and the Bayreuth Kulturkreis: A Study in Ideology. APPROVED BY MENIBERS OF THE THESIS COMIITTTEE:
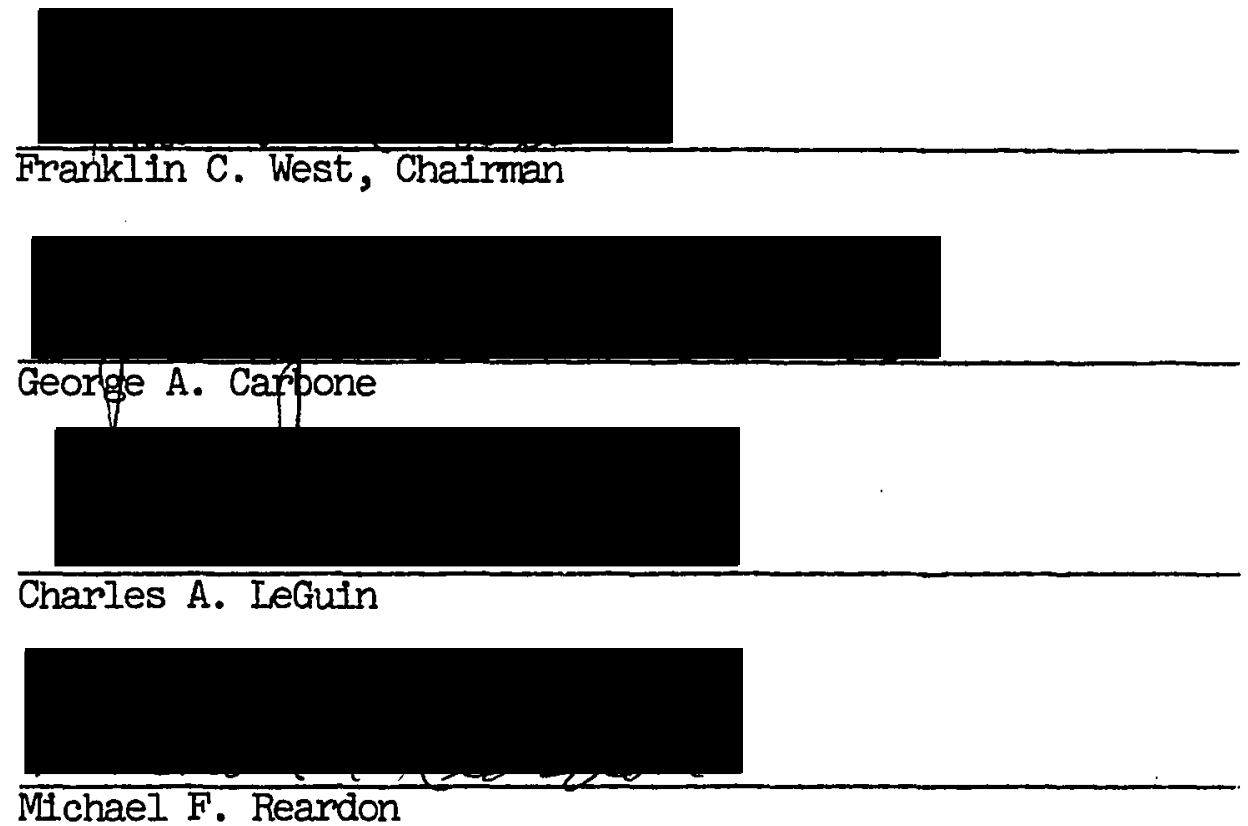

Houston Stewart Chamberlatn (1855-1927) was borm an Englishman but adopted Germany as his home. Chamberlain was a publicist for fin de siècle ideas about art and politics which were tempered by both late nineteenth century Imperialism and by World War One. As an old man he endorsed Adolf Hitler and has been credited as an Important synthesizer for the 1deology of National Soclalism.

This study examines Chamberlain's life in terms of his involvement with art and politics. It utilizes his work as a popularizer and his 
conversion into an exponent of Deutschtum to discuss broad social questions. While it is acknowledged that; Chamberlain was an important figure in the Germany of his day, this study attempts to place him and his idol, Richard Wagner, in the larger context of intellectual and cultural history. Insofar as Chamberlain was a "rootless" Intellectual, he was a paradigm. Accordingly, he is useful in considering the problems faced by intellectuals in the modem age of nationalism, technology, mass culture and alienation.

The works consulted were primarily Chamberlain's own publications and a variety of secondary accounts. Other research leads have been noted, but these would have to be pursued in Europe. Most of Chamberlain's life up to 1914 has been discussed by recent scholars. This study concludes that the period from World war one needs more research to account for the complex relationship between Chamberlain and the Bayreuth Kulturkreis, and National Socialism and modern society. 
TO THE OFFICE OF GRADUATE STUDIES AND RESEARCH:

The members of the Committee approve the thesis of David George Otness presented November 24, 1976.

Znauklin C. West

Franklin C. West, Chairman
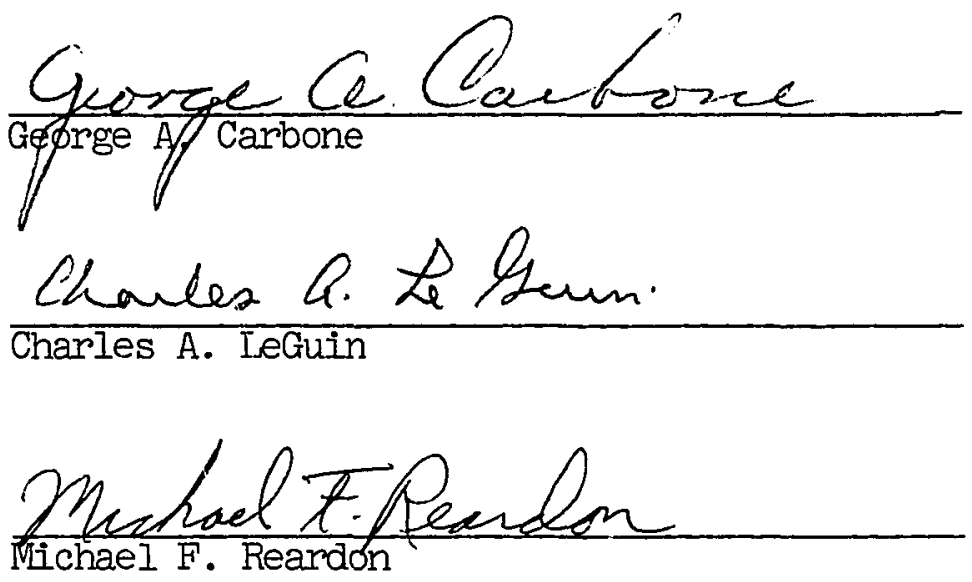

APPROVED:

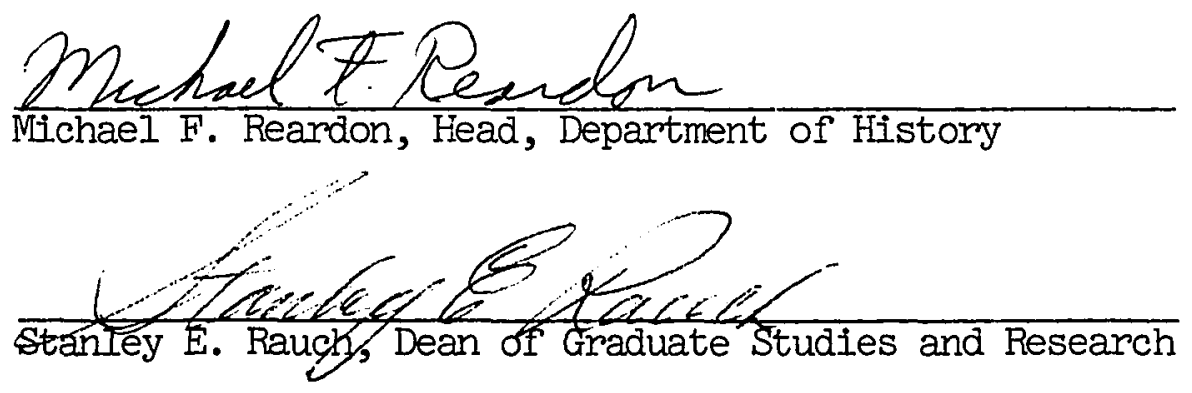


TABLE OF CONTENTS

CHAPTER

PAGE

I INTRODUCTION . . . . . . . . . . . . . 1

Overview .................... 1

Interpretations . . . . . . . . . 7

II THE NINETEENTH CENTURY BACKGROUND . . . . . . 14

Chamberlain's Intellectual Environment . . . 14

The Nineteenth Century German Evolution . . . 19

Popular Tradition and Anti-Semitism . . . . 27

III RICHARD WAGNER AND THE BAYREUTH KULTURKREIS . . . 34

Richard Wagner . . . . . . . . . 34

Cosima Wagner and the Inner Kreis . . . . 46

Wider Aspects of the Kreis. . . . . . . 52

IV CHAMBERLAIN'S YOUTH . . . . . . . . . 58

1855-1879: England and France ...... 58

From 1870: The Continent . . . . . . . 67

Music and Chamberlain's Jewish Friends . . . 77

V CHAMBERLAIN'S TRANSFORMATION .......... 86

1879-1884: Florence and Geneva . . . . 86

1885-1888: Dresiden : . . . . . . . 9?

From 1889: Vienna . . . . . . . . . 103 
CHAPTER

PAGE

VI CHAMBERLAIN'S VOCATION ............ 112

The "Writing Demon" and the Praeger Affair . . 112

Iebenslehre and the Foundations . . . . 120

VII DER FALJ CHAMBERLAIN . . . . . . . . 140

The Boer War and Kaiser Wilhelm II . . . . 140

Books, Divorce and Remarriage . . . . . 152

VIII THE TWENTIETH CENIURY WAR . . . . . . . . 167

World War one .......... 167

Chamberlain and the War Aims Movement . . 181

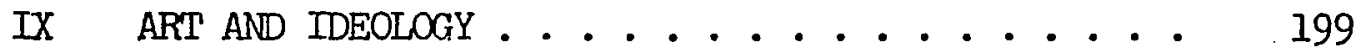

The Verrdterrepublik . . . . . . . . 199

Apotheosis ............... 208

X APOCALYPSE AND PHOENIX . . . . . . . . . 227

BIBLIOGRAPHY . . . . . . . . . . . . 237 


\section{CHAPTER I}

\section{INIRODUCTION}

\section{OVERVIEW}

Michael Foucault has argued that the "grid" of man's knowledge, so carefully buil.t in the medleval philosopher's systems, was overturned by the late eighteenth century. 1 This was signaled by the diversity of such creations as Diego Velasquez' painting "Maids in Waiting," by the writings of Cervantes and de Sade, and by the Iinguistic studies of Grim and Bopp. Foucault uses the late eighteenth century to illustrate the structural collapse of man's view of reality. For Foucault, the "grid" of representation, which through the medieval period had existed in a unitary form, became thin, brittle, and transparent; man with the late Enlightenment now found himself without the support of a coherent intellectual substructure from which to view reality, and began to hesitantly navigate over this uneven "table" of perceptions. In terms of Foucault's structuralism, the shift of man's perceptions between the eighteenth and the nineteenth centuries was composed of many factors. It was a social phenomenon, accompanied by and inseparable from the organizational ability of the mind. Allowed to drift on the disintegrating "table" of understanding, man since the late Enlightenment

IMichael Foucault, The Order of Things: An Archaeology of the Human Sciences (New York: Pantheon Books, 1970). 
has clutched at fragments left over from the earlier periods of intellectual coherence.

For Foucault, this distinctly modern problem only approaches resolution with our own day, and only through the formlation he himself presents. Clearly, this definition of modern "uncertainty" and the fragmentation of knowledge has parallels with other, older theories -the utility of Foucault's view is his reformulation of Weltanschauung, of paradigm, of intellect. He delineates change as occurring in transcultural, trans-historical and trans-ideational structures, or epistemes. These massive blocks of time are useful for the understanding of volatile questions extant since at least the eighteenth century. Most particularly Foucault's formulation can usefully be applied to the problem of ideologles. Thus, while retaining the historicity of, for example, Communism and Capitalism, it is possible to compare the shared structural concerns of these 1deologies. Discussions about Freedom as well have occurred on every side of ideologies. It is peculiarly significant that the actual expressions of Nationalism, Ultramontainism and Internationalism have allegedly shared concerns for such values as "Freedom." Since the eighteenth century there have been dialectical preferences visible in such potent mixtures as "Right" and "Left" political sentiments, particularism or universalism, logical or aesthetic constructions, religion or materialism, and authoritarian or "anarchic" values. The extraordinary variety of combination in this bewildering spectrum makes sport with such simplistic explanatory devices as "Conservative" or "Liberal," or "Right" or "Left." Since the Enlightenment social and Iinguistic theorists have 
debated such issues as the progress of man, ethical and social responsibility, Romanticism and Classicism, Sensualism and Spirituality, Materialism and Idealism, Naturalism and Surrealism. The comon element in this collection is a consistent attempt to expand the boundaries of human understanding beyond the pre-Enlightenment categories of knowledge. In the process of redefining man's realm, the eighteenth century emphasized material, physical and technological concems in men's lives, while, similarly, religious and historical assumptions were reformulated. This shift was indicated when Laplace and Condorcet viewed man in terms comprehensible to reason imespective of the blessIngs of Providence. Similarly, the natural science and linguistic inquiries of the late eighteenth century formulated explanatory models in terms of readily-understandable method: science and rationalism. The entire shift, then, to "moderm" considerations of social theory, to mechanism and to non-theological explanatory modes may be seen accompanying the political development initiating "modern history," the French Revolution.

The world since 1789, however, merely retrieved a collection of Weltanschauungen, a group of explanatory modes underlain by theories of contemporary and more ancient vintage. Some were as old as those of the Greeks, of St. Augustine, of Nicholas of Cusa or Meister Eckhart. Others were as recent as the nearly overlooked Giambattista Vico. While all areas of man's knowledge thus were influenced by pre-1789 thought, the salient fact is that ever since 1789 Western man has observed that no underlying unity chardcterized these earlier "intelligences." While religion appeared to be outmoded by the time revolutionary armies remade Europe af'ter 1789, religion remained significant 
in the lives of the vast majority of men. Similarly, while science explained more and more of what Darwin by mid-century would formulate as Evolution, the modes of viewing reality supposedly thrown off by this "science" (i.e., obscurantist religion, vapid metaphysics, common ignorance, etc.) still possessed a remarkable vitality.

Teleology was retained by scientific and political philosophies which in the nineteenth century claimed not to need the services of any such "antediluvian" trappings. Messianism likewise was retained by völkisch and national prophets who increasingly defined new forms for man's salvation. As Hayden white has noted, even in the craft of history the very explanatory modes of antiquity were revitalized and carried forth in various nineteenth century Tragic, Romantic and Comic roles. ${ }^{2}$ Men viewed their world from the late eighteenth century not necessarily in terms "objective" or "scientific," implying that time itself had begun with 1789. Indeed, time as a repository, a continuum, reigned supreme in the histories, aesthetics and moral systems of men as widely differing as Hegel, Blake and Bentham. The working-out of the intellectual questions left by the post-1789 "modern society" has thus perhaps not ended with our own time.

The issue at hand for this study is a series of questions directed toward the above problems. How is it that before World War Two men from nearly every society and social grouping found common ground in theories subsequently reified into the political "isms": Anarchism Communism, Fascism or National Socialism? Theodore Roosevelt, for

2Hayden White, Metahistory: The Historical Imagination in Nineteenth-century Europe (Baltimore \& Iondon: The Johns Hopkins University Press, 1973). 
instance, greatly revered vitality, will, and racial explanations. While Roosevelt's donestic politics showed a sensitivity to human suffering, on the international level he denied any logical carryingout of such "tender-mindedness." Instead, he saw the white race struggling against "barbarian" peoples. Perhaps a psycho-h1stortan would utilize such Freudian explanatory devices as "compensation" and "sublimation" in viewing this problem. The present study refers to men such as Theodore Roosevelt and Carl Becker-among other cultivated Westermens--who found much that was valuable in the "proto-fascist" writings of a H. S. Chamberlain before 1914 .

A rurther problem is that a list of men who found conmon ground with the "vitality" of fascist, even occasionally National Socialist movements, reads like a "Who's Who" of twentieth century intellectual, piilosophical and literary history. This list might include many prominent Germans such as Heidegger and Heisenbelg, but most importantly many non-Siermans were represented: Yeats, D. H. Lawrence, Ezra Pound, Evelyn Waugh, Wyndham Lewis and many "Vichy" Frenchmen still familiar today. Now, as in the 1930's, writers receive praise who aided Republican Spain, but the pro-Franco side was by no means composed of merely second-rate individuals. It would be-and has often been-- a serious misrepresentation of the Western sympathy for fascist viewpoints to ignore these supporters of egreglous ideologies. Not even Hitler had a crystal ball which could foretell the Second World War and its consequences. For in the inter-war decades, when the failure of capitalism to solve its own problems was manifest, when the Bolsheviks appeared to be raising Russia to modern status, the 1922 "March on Rome" by anarcho-syndicalist fascisti often was seen 
as a hopeful, not an apocalyptic, event.

To the contemporary American student of the late nineteenth and the early twentieth centuries, the figure of $\mathrm{H}$. S. Chamberlain presents an intriguing lumber of contradictions illustrating the above-described problems. Chamberlain was born an Englishman, but came t;o endorse Germany's Machtpolitik and Hitler himself. He was a well--read, cosmopolitan Christian who particularly praised St. Paul, Rousseau, Shakespeare, Kant and Goethe, but ultimately endorsed racial determinism. He upheld Liberal political goals early in his life, but came to support some of the most reactionary-revolutionary movements known to modem history. He was a diligent writer, a Kulturkri.tiker, but came to uncritically adopt an inflexible ideology. He was a lover of culture and sensitivity such as he found in Stearne, Rousseau and Wagner, yet he eventually re-:valuated nearly everything in terms of anti-Semitism and the Bayreuth Idea of Totalitarian Art.

Chamberlain is relatively unknown as a serious thinker anywhero today. His intellectual status is justly seen as second-class, superficial and gilded only with the jewels of pillaged libraries. He is appreciated orily as a bizarre fanatic who curiously entranced preWorld War Germany and proviled an intellectual link to Hitler. But Chamberlain was a cultured, articulate and fascinating man in his own right. He was nearly universally acclaimed by the press of his day as a provocative, often "seminal" writer. His reformulations of intellectual history and of the German traditions dear to nationalists were vastly popular. Chamberlain did not need Nazi support to become a great popularizer of völkisch views; there are even indications he would ultimately have been unhappy with such Nazi actions 
as the 1938 Kristallnacht. 3

I think, then, there exists much more room for work on the question of bourgeois society's political transformations, on the psychological, aesthetic, religious and philosophical issues raised in the case of H. S. Chamberlain. My own preference in the welter of raw data and often extremely biased sources is to weigh the "Kantian" aspects in the lives of both Chamberlain and his idol, Richard Wagner. That is, both of these men understood German idealism as seeking to unite aesthetics and reality. In a real sense their lives and the political movements of the twentieth century have similarly attempted to reunite man's shattered perception of himself. These men themselves, furthermore, changed over the course of their lives; they embodied rather than overcame contradiction. It is with this sense of irony at man's foibles that a study of the Bayreuth Idea and H. S. Chamberlain should be understood. In this problematic realm where artist, priest, thinker and soldier dissemble, even the ravings of National Socialists have some relation to the modern bourgeois world in which they lived, and the world they left behind.

\section{INTERPRETATIONS}

Students without access to the Bayreuth archival sources maintained by Eva Chamberlain, then by Winifred Wagner, and to the various government agencies in the town of Bayreuth, encounter grave research

3Robert Edwin Herzstein, "The Wagnerian Ethos in German History, 1848-1933: A Reinterpretation of Richard Wagner's Historical Signifance," (Ph.D. dissertation, New York University, 1964), p. 323. This was, at any rate, the comment of his widow, Eva Chamberlain. 
difficulties. Fortunately, these sources have been used by at least two contemporary scholans, Geoffrey Field from Columbia University, 4 and Winifred Schuler from the University of Munster. 5 Both have written extensively about Wagnerism and Chamberlain, but make little attempt to relate these topics to subsequent events, and the former work on Chamberlain ends with 1914. Schüler catalogues and interprets the quite extensive Kreis, and Field alludes to having prepared a larger study of Chamberlain. Future publications by these authorities should be extremely valuable. There are, as well as the Bayreuth Nachlässe, Chamberlain family records and letters from H. S. Chamberlain housed in the County Record Office at Gloucester, England. 6 Cosima Wagner's papers in Munich were scheduled to be opened to scholars in 1972, and are being prepared for publication by Piper Verlag, Munich. These sources should continue to provide important material for evaluating a wide selection of problems. However, in North America, Chamberlain publications are wldely scattered among libraries, available only incompletely, and with patience, through the services of University Inter-Library Loan.

It should be noted that a great deal of work has already been done in the area of Wagner and Wagnerism which is important for considering Chamberlain. The issue, I think, will increasingly be whether

4Geoffrey George Field, "Houston Stewart Chamberlain: Prophet of Bayreuth," (Ph.D. dissertation, Columbia University, 1972). This is available through University Microfilms, Ann Arbor, Michigan.

5Winifred Schüler, Der Bayreuther Kreis von seiner Entstehung bis zum Ausgang der Wilhelminischen Ara: Wagnerkult und Kulturreform im Geiste völkischer Weltanschauung (Münster: Aschendorff, 1971).

6 This is mentioned in Colin Holmes, "Houston Stewart Chamberlain in Great Britain," Wiener Library Bulletin 24 \#2 (1970): 31-36. 
scholars can discover linkages in aesthetic theory and political deed which alone would validate the earlier-century claims that wagner (not to mention Chamberlain) was a "proto-Nazi." I think the revelations by such scholars as Field, Schllier, Newman, Gutman and Herzstein 7 will demonstrate radical political movements have indeed been indissolubly united with aesthetic movements. The issue raised by these studies is the bourgeois conmon root of modern ideological mutations. This has been explored by many scholars, including Ernst Nolte, Lucien Goldmann, Herbert Marcuse and Martin Jay. ${ }^{8}$ These authors in particular focus on the comparative aspects of Communism, Fascism, Nationalism, and bourgeois society. An advantage in studying a figure such as Chamberlain, then, is his own voluminous publishing record and the well-documented association he maintalned with prominent contemporaries.

7Field and Schüler are cited above. The standard Wagner biography is the massive Ernest Newman, The Life of Richard Wagner, 4 vols. (New York: Alfred A. Knopf, 1933-1946). More recently a fine but rather blatantly anti-Wagner interpretation is Robert W. Gutman, Richard Wagner: The Man, His Mind, and His Music (New York: Harcourt, Brace \& World, Inc., 1968). Another recent work which, however, suffers from a pro-Wagner bias and apparently the use of only non-Bayreuth sources is Robert Edrin Herzstein, "The Wagnerian Ethos in German History, 1848-1933: A Reinterpretation of Richard Wagner's Historical Significance" (Ph.D. dissertation, New York University, 1964); Herzstein has also published a more recent article in which he modified his original thesis, but still, for example, insists on the racial antiSemitism of Nietzsche. Robert Edwin Herzstein, "Richard Wagner at the Crossroads of German Anti-Semitism 1848-1933. A Re-Interpretation." Zeitschrift für Die Geschichte der Juden Nr. 3/3 (IV Jahrgang, 1967): 119-140.

${ }^{8}$ See Ernst Nolte, Three Faces of Fascism: Action Francaise, Italian Fascism, National Soclalism, trans. Lella VennewItz (Whinich: Piper, 1963; New York: Mentor Books, 1969); Lucien Goldmann, Immanuel Kant, enlarged and revised ed. (Zürich: Europa-Verlag, 1945; London: NLB, 1971); Herbert Marcuse, Reason and Revolution: Hegel and the Rise of Social Theory, revised 2nd. ed. (New York: Oxford University Press, 1941; Boston: Beacon Press, 1960); Herbert Marcuse, One-Dimensional Man: Studies in the Ideology of Advanced Industrial Soclety (Boston: Beacon Press, 1964; and Martin Jay, The Dialectical Imagination: A 
As mentioned in this study, he knew the Kaiser, Count Harmam Keyserling, Adolf von Harnack, Julius Wiesner, Jacob von Uexküll, Count BrockdorffRantzau, Arthur Rosenberg and Adolf Hitler. The number of his correspondents is itself a bibliography of the day's influential Germans.

The American student of this problem, utilizing mainly secondary sources, will be best served by first examining the two dissertations mentioned and Chamberlain's oeuvre itself. This, however, totals 314 titles. His memoirs 9 were written as part of his War Aims Movement work during the First World War. The published volumes of Chamberlain letters are also very helpful. 10 Chamberlain's first wife published her own memoirs during the Weimar Republic, 11 and many other books written before the Nazi seizure of power discuss Chamberlain.12 The large number of purely Nazi works on Chamberlain appear to have been researched only from his publications and thus suffer from both Nazi

History of the Frankfurt School and the Institute of Social Research 1923-1950 (Boston: Little, Brown and Company, 1973).

9Houston Stewart Chamberlain, Iebenswege meines Denkens (Munich: Bruckmann, 1919).

10Houston Stewart Chamberlain, Houston Stewart Chamberlain Briefe - 1882-1925 und Briefwechsel mit Kaiser Wilhelm II, 2 vols. (Munich: Bruckmann, 1927). The companion letters are Cosima Wagner und Houston Stewart Chamberlain im Briefwechsel 1888-1908, Herausgegeben von Paul Pretzsch (Ieipzig: Reclam, 1934).

1IAnna Chamberlain (Horst), Meine Erinnerungen an Houston Stewart Chamberlain (Munich: Oskar Beck, 1923).

12 For example, Leopold von Schroeder, Houston Stewart Chamberlain: Ein Abriss seines Lebens, auf Gmond eigener Mitteilungen (Munich: ${ }^{\prime}$. F. Iehmann, 1918). 
and Chamberlain's own bias.13 With the exception of archival organizing after World War Two by Walter Einsle 14 it appears the original documents housed in Bayreuth were not used by scholars until the late 1960's.

During the First World War, Leo Spitzer made a particularly cogent examination of Chamberlain's propaganda. 15 However, publications increasingly tended to lump together Chamberlain's ideas under the nationalist and the anti-Semitic ideologies of the Third Reich period. Interesting exceptions to this trend did occur, as, for example, a Nazi journal article argued very early Chamberlain was important as a writer, but not a direct cause of the National Soclalist movement. 16

13Alfred Rosenberg, Houston Stewart Chamberlain als Verkünder und Begrun̈der einer deutschen Zukunft (Munich: Bruckmann, 1927); and Dskar Doring, Ein Deutscher namens Chamberlain: sein Lebensbild nach seinen elgenen Worten, Aus deutschen schriftum und deutscher kultur series, vol. 549 (Iangensalza: J. Beltz, 1937).

${ }^{14}$ Schüler intriguingly mentions this ran organized the Chamberlain archives after World War Two and wrote a 1955 article "H. S. Chamberlain und der Bayreuth Gedanke" in the Bayreuther Tagplatt "E. hat den umfangreichen Ch.-Nachl. nach dem Kriege geordnet und registriert." ] Der Bayreuther Kreis, p. 114. This is not cited by the later-appearing Field dissertation, which states his work is based on "the Bayreuth archives and rests on evidence which has, for the most part, never been previously used by historians." "Houston Stewart Chamberlain: Prophet of Bayreuth," Abstract, p. 3.

15Leo Spitzer, "Anti-Chamberlain: Betrachtungen eines Iinguisten Über Houston Stewart Chamberlains 'Kriegsaufsatze' und die Sprachbewer tung im allgemeinen." Während der Militardienstzeit, Aufsatze von Dz. Dr. Leo Spitzer (Leipzig: 0. R. Reisland, 1918).

16Fritz Peudert, "Chamberlain und Nietzsche," Nationalsozlalistische Monatshefte, vol. 49 (April 1934), pp. 11-17. 
This remains one of the soundest judgments made about Chamberlain and Nazism. The religious writer's Certrud Frischmuth 17 and Desiderius Breitenstein 18 as well criticized the reception given Chamberlain's hatreds in the new Reich.

Publications about Chamberlain in English before World War One were generally favorable. After 1915 they were unfavorable. According to Colin Holmes, an attempt was made to destroy the evidence of pre-war cooperation with Chamberlain in England after 1914.19 But, with the interwar period, such old friends as Lord Redesdale again made the "pilgrimage" to Bayreuth, the then-Nazi shrine. Information about such visitors should be valuable. Again, with the coming of the Second World War, books and articles were printed criticizing Chamberlain the "renegade," but scholarly works as well reopened the entire issue of Wagnerian Ideology. Particularly important in English was Peter Viereck who evidently "discovered" the intellectual problem of "protoNazis,"20 and Jacques Barzun who in considerably more scholarly f'ashion sketched the outlines of the problem.21 Since the Second World Wal

17Gertrud Frischmuth, Houston Stewart Chamberlain als Christ (Gutersloh: Bertelsmann, 1937).

18Desiderius Breitenstein, Houston Stewart Chamberlain: Ein Wepbereiter des Rassischen Weltbildes (Warendorf: J. Schnellsche, 1936). p. 34 .

${ }^{19}$ Colin Holmes, "Houston Stewart Chamberlain in Great Britain,"

20Peter Viereck, Metapolitics: The Roots of the Nazi Mind (New York: Alfred A. Knopf, Inc., 1941; revised and enlarged edition of [Metapolitics: From the Romantics to Hitler] New York: Capricorn Books, 1961).

${ }^{21}$ Jacques Barzun, Darwin, Marx, Wagner: Critique of a Heritage (New York: Anchor Books, 1941; reprint ed., New York: Anchor Books, 1958). 
only a few books and articles have appeared about Wagnerism, and fewer still on Chamberlain. Many memoirs and secondary works make mention of this issue, however, and their continued publication should provide more material for later work on the entire subject. 22

22Increasing numbers of books are becoming available. An example is Count Hermann Keyserling, Reise durch die Zeit (Innsbruck: Verlag. Der Palme, 1948). The recently-opened Cosima Wagner papers as well should provide research leads. Particularly good sources for a broad range nt' secondary works are Gutman, Richard Wagner: The Man, His Mind, and Hili.j Music; and Fleld, "Houston Stewart Chamberlain: Prophet of Bayreuth." 


\section{CHAPTER II}

\section{THE NINEIEENIH CENIURY BACKGROUND}

\section{CHAMBERLAIN'S INTELIECTUAL ENVIRONMENT}

H. S. Chamberlain grew up in a social and intellectual atmosphere of hatred, fear and apprehension about the future. From the upper class, he sought identification with political and social status quo. As did many cultured Europeans in mid-century, Chamberlain found challenges on all sides to his basic values. These enemies were tiberalism, Socialism, Nationalism and Materialism. Though Chamberlain himself eventually joined the pantheon of nationalist German heroes, his early years were most influenced not by Teutonic but by English and French cultural models. While making the judgment that he simply chose the worst models to emulate is tempting, it would not seem accurately to depict the realities of nineteenth century life.

In general, the great task of historically-minded intellectuals such as Chamberlain was to explain the transition found in the history of European civilization. It had begun with the Napoleonic assault on the state structure and by late century had seen the transformation of the old systems into a new imperialism. While the governmental structure of most of the nations affected during Napoleon's time had returned to apparently normal conditions, political hegemony was increasingly dependent not on agricultural interests but upon comercial classes. 
It had not been possible to recast reality into the pre-1789 mold. Instead, revolts had erupted on a large scale in France in 1830 and 1848, then throughout the rest of Europe. The social institutions forming bulwarks of government support--Church, the home, property rights, the material and intangible interests defended by threatened social classes-were faced by a voracious "modermity."

From the English viewpoint, the particular virulence of socialist ideas was not wholly prevented from crossing the English Channel. More perceptive English critics might--but in general did not--point out the social parallels of the sans culottes which had been found in England as well as in France before and during the 1789 Revolution. ${ }^{1}$ But all recognized the same issues which by terror (i.e., the Peterloo Massacre) and legislative means (i.e., the several Reform Bills) had changed England. The brief Crimean War revealed the gap between expectations of a relatively self-satisfied aristocracy and the inadequacy of its military effort. By late century, imperial demands increasingly emphasized technological as well as moral dominance of Europeans, forcing: a re-evaluation even of domestic life. With the extension of scientific achievement, social frustration was expressed in the trade union, popular religion, even revolutionary movements displaying a divisive substructure to society. Viewing this disparity, intellectuals in the nineteenth century often sought solutions based less in social than in philosophical analysis.

Chamberlain's generation sought to achieve social harmony. But;

$I_{\text {Gwyn A. Williams, Artisans and Sans-Culottes: Popular movements }}$ in France and Britain during the French Revolution, Foundations of Modern History Series (New York: W. W. Norton \& Company, Inc., 1969). 
the background many Victorians brought to such a consideration had roots in the Western traditions of the Enlightenment. The eighteenthcentury Enlightenment was an amorphous collection of cultural styles and disciplines which still operated for nineteenth century thinkers. It provided the framework for multiple intellectual views. For a Mill or a Bentham or a Blake interpretations of reality lay almost directly Juxtaposed. Even today the conceptual problem of the Enlightenment finds little consensus. One solution has been to brand as conservative or evolutionary, humanistic or totalitarian, the various schools of thought represented by Voltaire and Laplace, or by Kant and Rousseau. ${ }^{2}$ Even defining the scope of the Enlightenment appeared and still today appears more an exercise in political definition than a certain demarcation of agreed-upon values. But the Enlightenment was shattered from within, producing contrary rationals, finally ideologies. Leonard Krieger has suggested a tri-partite division of the Enlightenment which deals with this important intellectual development.

For Krieger, the late Enlightenment dialectically evolved into increasingly reified segments from what originally were merely artistic preferences or theoretical predilections. Between 1770 and 1789 he identified first a "radicalization" of Enlightenment rational prefer ences into rigid schools of atheism, determinism and progress, and cited as examples Hollbach, Laplace and Condorcet. Secondly, he noted the transformation of Enlightenment "individualizing, liberalizing and

$\Sigma_{\text {Iris }}$ controversy continues in the recent work of Judith $N$. Shklar, Men and Cltizens: A Study of Rousseau's Sorial Theory (Cambridge: At The University Press, 1969). 
dynamic principles into the utilitarian, sentimental, idealistic, naturalistic, and evolutionary creeds" seen, for example, in Bentham, Rousseau, Kant, Godwin and Lamarck.3 The third type of thought for Krieger was the actual revolt of the Enlightenment against itself. This was a rejection of the highest aspirations of the Philosophes, and in their stead positing individual, anarchic or even demonic powers. The latter could be seen in the movement of the Sturm und Drang, in the organicism of Burke, and in the mysticisms of Blake. Further, Krieger identified the nineteenth century political schools which emanated from this late eighteenth century division:

The detailed consideration of the three strands of this intellectual revolution will show the first forms taken by the typical revolutionary parties of modern times: the party that desires a radical execution of the systematic order promised by the old Regime; the party that desires a radical execution of the Freedom promised but compromised by the Old Regime; and the extreme party that wants no part of the Old Regime and would inaugurate an age categorically new. 4

Important for a study of reactionary intellectuals in the later nineteenth cer.ury, such as Chamberlain, is the vehemence of this latter "demonic" element, noted as well in such artists as the painter Gericault. 5 The inheritors of these three "strands" of the Enlighten-

3Leonard Krieger, Kings and Philosophers 1689-1789 (New York: W. W. Norton \& Company, Inc., 1970), pp. 209-210.

${ }^{4}$ Ibid., p. 210.

5 This is the judgement of the contemporary art critic Kenneth Clark, The Romantic Rebellion: Romantic versus Classic Art (New York: Harper \& Row, 1973), pp. 199-222. While art criticism remains a delicate field for historical analysis, Clark's treatment of Gèricalltt has the advantage of itself being solidly "conservative." The choice of Gericault, then, is illustrative of the 1deology which itself denounces "romanticism," ascribing to it "demonic" tendencies. 
ment all claimed their own interpretations to be the truest continuations of the finest Enlightenment traditions. While revolutionary parties such as socialists, anarchists, and communists thus represented a hope for man's future and freedom, the parties of the right similarly vowed that through their stewardship man's true interests would be salvaged. However, as a class phenomenon, the dominant vehicle for middle and upper-class Englishmen (as well as their cousins on the continent) characterizing their intellectual endowments, came from the political right wing. For reasons economic, religious and political, the aristocracy and their middle-class rival found comfort in Burkean conservatism, in Mill's liberalism, in the tutorial leadership of the Conservative and Liberal parties.

This characteristic amalgamation was "Victorian sensibility." It found neo-romanticism, feudalism, and paternalistic capitalism the answer for solving social problems, while it was simultaneously receptive to individualizing criticisms and organic philosophies. Generations in England were thus raised on intellectual diets not simply of Coleridge and Wordsworth, but Byron, Keats, Shelley and Scott and Carlyle. The spill-over of literary influences into historical criticism here-especially in the case of Carly le-became a veneration of organicism and heroicism parallel to that of the German and French historians. Often sensitive to nuance, to the destructiveness of capitalism, and to the inadequacies of the English system of political representation, these literary influences were felt by men as diverse as Bernard Shaw, William Morris-and H. S. Chamberlain. 
Thus the intellectual tensions of the late Enlightenment were simply deepened in the nineteenth century for the British intelligentsia in academic, literary, theological and political aspects. Chamberlain discovered the German society to the east by the time he was a young man, financially independent and conversant with English and French cultures. There he was to encounter philosophies and cultural influences which varied greatly from much of his former background. In his introduction to Germanic culture, he found massive changes had occurred in European society. One peculiar response to the new Imperialism, the new political mass parties, the new military technology, was the acceptance of a new popular faith which found fulfillment in the Germanies: political anti-Semitism. 6

THE NINEIEENTH CENIURY GERMAN EVOLUTION

The British in the nineteenth century can be seen as increasingly concerning themselves with the economic and moral responsibilities of Empire. The French can be viewed as attempting to adjust to their twin polarities of tradition and revolution. The intellectual forces of the West, however, simply did not penetrate the Rhine barrier in unaltered form. It seemed that cultural and linguistic borders, particularly the German frontier, transformed ideas. The contributions returning from Germany to the West since the Aufklärung retained a distinctiveness based on what has increasingly been entitled Weltanschauung.

$6_{\text {See, for example, Peter G. J. Pulzer, The Rise of Political }}$ Anti-Semitism in Germany and Austria (New York: John Wiley \& Sons, 1964). 
Certainly Germans in the very recent period (until the Second Republic) have been the anti-democrats, the anti-liberals, the "spoilers" of the West. However, a view of the absolute separateness of Germany tends to overlook many common features in the history of the European peoples, and fails to explain German developments shared by the West. An opposing view states that Germany has been only the at-times disastrous representative of many characteristic Western values; German demonstration of extremes in mysticism and militarism have simply permitted other nations to at least conceptually separate themselves from the German Problem. Between these two views--which have numerous connected arguments from Marxism to Totalitarianism-is a recognition that Germany can be neither separated from Europe, nor can it be entirely viewed independently of such political events as, for example, National Socialism.

In reacting to the French Enlightenment, Germans such as Treitschke have frequently found the basis for defining Deutschtum, even Deutsches Volk as a distinct social species. Uften harkening back to Nicolaus of Cusa and Meister Eckhart, many Germans have insisted Germans were nurtured on a Geist, special and somehow more worthy than mere English "pragmatism" or French "rationalism." The tradition of the German Siegfried unfairly treated by his jealous political and cultural neighbors has often given rise to views that, for example, Luther was the eternal German, 7 and that great German leaders and their mythologies

7See, for example, Gerhard Ritter, Luther, His Life and Work, trans. John Riches (London: Collins, 1963). 
united with a civilizing Drang nach Osten should justify pure aggrandizement.

However, in the early nineteenth century, considerable veracity may be ascribed to the arguments of German patriots. Until the last third of the nireteenth century, the continental power most feared was France. Intermationally, the Britj.sh Empire had secured hegemony, and the Napoleonic occupation of Europe had demonstrated powerlessness existed east of the Rhine. The concatenation of bureaucracy and autocracy $^{8}$ in the expanding eighteenth century Prussian kingdom was itself the "miracle" tale of European states. Ultimately, the invading French Revolutionary and Imperial armies nearly destroyed this smallest great, power, and it is from the story of Prussian regeneration that some of the most peculiar aspects of German culture grew. While the nineteenth century Austrian role in ruling the polyglot Habsburg Empire was increasingly attacked by its constituent peoples, actual power divided into blocks by religion, dialect, economy and self-estimation.

In Fredrich Meinecke's judgment, the real failure of the Wars of' Iiberation was the suppression of cosmopolitanism. The very possibilities of Bürger control were necessarily destroyed by the exertion of awakening the "German" spirit.9 Considerable disagreement exists as to whether the notions of even the most noted Prussian Reformers of the Reform Era were anything more than mere shadows, rather than sub-

$8_{\text {This is developed in Hans Rosenberg, Bureaucracy, Aristocracy }}$ and Autocracy, The Prussian Experience 1660-1815 (Boston: Beacon Press, 1958).

9Friedrich Meinecke, Cosmopolitanism and the National State, trans. Robert B. Kimber (Munich: Oldenbourg, 1963; Princeton: Princeton University Press, 1970). 
stantial representatives, of a Western European consciousness. It appears that the intentions of this generation were mixed, and easily subject to the political dominance of Hohenzollerm interests once Napolean was defeated. However, many of these reformers were dedicated, sincere upholders of humanity as evidenced by, for example, the case of William von Humboldt. 10 The fact of their defeat was not only a German tragedy but a European necessity. It was dictated by the national interests of the major Allied powers and France as well. 11 The period of reaction after this Prussian Reform Era was accordingly never the same as pre-1806 authoritarianism. All powers saw the real danger in Europe after 1789 as Nationalism: i.e., the consciousness of and loyalty to some "higher" power than transient temporal authority. In the German case, nationalism developed in opposition to French cosmopolitanism, Imperialism, and the principles of 1789. The legacy, however, of the French Revolution's universalizing tendencies was not entirely ignored, and helped the Germans explore their own cultural setting.

This cultural awakening of Germany had begun with the literary influence of the French Enlightenment, and was then inundated by the political events of the late eighteenth century. While the young philosopher-artists of the eighteenth century Sturm und Drang spoke

10For exarmle, see Wilhelm von Humboldt, Humanist Without Port folio: An Anthology of the Writings of Wilhelm von Humboldt, ed. Marianne Cowan (Detroit: Wayne State University Press, 1963).

11This is developed in Henry A. Kissinger's A World Restored: Metternich, Castlereagh and the Problems of Peace 1812-1822, and ed. (Boston: Houghton Mifflin Company, 1957). 
of Geist and Kultur as basically literary activities, by the time of the French Revolution the actual decay of the Ancien Régime in a political sense was unmistakable. Kant, the greatest figure of the Aufklärung, never ceased admiring the Revolution's positive aspects and retained his respect for Rousseau particularly. However, most of the early nineteenth century "Young Germans" were to become, with their fathers, repelled by revolutionary excesses, the turn toward selfdestruction and increasing authoritarianism. Actual events were transposed to the realm of theory; the principles of 1789 and the French policies were both rejected. Young enthusiasts, the Schlegels, Fichte, Schelling and even Hegel, all reacted by redefining their philosophies in terms of the concrete needs of defeated Europe. For the first time, nationalism became a viable force in the occupied nations of Europe. The German use of Freikorps and Burschenschaften date from this time, and the dissonant crudity of "Father Jahn" and the nationalistic rhetoric of Arndt and even the sermons of Schleiermacher served the very concrete needs of the nearly-obliterated Prussian state. While traces of antiSemitism were visible in this early nationalism, 12 the German War of Liberation embodied a genuine welling up of new-found identity. Clearly the French successes in great part had been due to German disunity, and just as clearly, the different peoples of the German-speaking world had goals which were increasingly removed from their former Kleinstaat aile-

$12 \mathrm{An}$ earlier commentator made much of there being a patriotic club at this time attended by many of the day's cultural leaders which excluded Jews. Peter Viereck, Metapolitics: The Roots of the Nazi Mind, revised and expanded (New York: Alfred A. Knopf, Inc., 1941; New York: Capricorn Books, 1961), introduction, p. xv. 
giances. Of paramount importance, then, was this ambivalent first use of nationalism in Germany, a necessary but distrusted tool for driving back France.

In the early nineteenth century the myriad of Germanies attempted to assert their independence. Despite the efforts of restoration govermments, it was not possible to recreate the stability of the pre-1789 Ancien Regime. Mid-century revolutions in France itself greatly affected the rest of Europe, and governmental forms fitfully adapted to at least the outlines of modern democracy: representative bodies, shared responsibility, and economic liberalism. Earlier German developments such as the Zollverein and the infusion of technology in the latter century contributed to a great industrial development. Workers' revolts and socialist iceas were regularly suppressed in Metternichean Europe, and the very Burger class pressing for social stability in the examples of England and France remained emasculated in Germany. After 1848, German Liberalism was harnessed to the dictates of Aussenpolitik, to established authority, buffeted by the increasing, challenges of modernity.

Leonard Krieger has pointed out that the corporatism of traditional German life was enclosed within the increasingly efficient Prussian state. 13 The last nineteenth century hope for a less authoritarian development was defeated soon after 1848-1849. The social result of this failure in Germany was a willingness to support established paternalism, elitist education, and class rigidity. With unification in the

13see, for example, Leonard Krieger, The German Idea of Freedom: History of a Political Tradition (Chicago: University of Chicago Press, 1957). 
years 1864-1871, the definition was broadened to include nationalism, now recognizing the new Kaiser as titular ruler of a federated state. But the Bismarckian construction of this state proved unwieldy in the less adroit, less sensitive hands of his successors. Withal, the position of individual German citizens was subordinated to the greater interests and knowledge of constituted authority. Cultural pursuits, Bildung, held sway as ideals for the educated classes, while the lower classes were often abandoned to popular religion, Volk ethics, and often characteristically crude prejudices.

In this context, German Idealism became less important in political terms, but more useful as a social myth maintaining existing authority. 14 Hegel was rejected in favor of alternative forms of inwardness, even anthroposophy, for example, in such cases as Schelling, Schleiermacher, and such Right Hegelians as D. F. Strauss. Germnan intellectual life became concentrated into increasingly rarified academic and derivative forms, exacerbated by the overproduction of academic degree-holders. Thus with a decline of the "Mandarin" class, 15 by late century, an increasingly academic proletariat of unemployed or underemployed educated men were available f'or popular culture, music, religion, non-university education and the press.

But easily enough, with the economic ascendency of the new Eumire

${ }^{14}$ See, for example, Hajo Holborn, "German Idealism in the Light of Social History," in Germany and Europe: Historical Essays by Hajo Holvorn (Garden City, New York: Doubleday \& Co., 1970; Garden CIty, N.Y.: Anchor Books, 1971), pp. 1-31.

15Fritz K. Ringer, The Decline of the Mandarins: The German Academic Community, 1890-1933 (Cambridge, Massachusetts: Harvard University Press, 1969). 
and the new late-century race for colonies, German social ethics relied heavily on increasingly specific notions of nationalism, popular religion, völkisch values, and the neo-Kantian separation of "pure" from "practical" reason. Rather than the democratic model of citizen initiative and responsibility fostered in England, the German Empire's aristocracy and leading economic groups ruled with an often unappreciated moral authority. Frequently it has been suggested that the insularity of this peculiar system was the reason a real dialogue did not exist in German society until at least the time of the Weimar Republic, 19191933.

For the present study, the combination of intellectual, economic, political and technological forces visible by about the 1870-1880's in Germany is of great importance. There was the general European last "rush for colonies," the prevalence of materialism, the hardening of' nationalisms and the awakening of numerous subsidiary social movements, not the least being Socialism. This period saw a shift of emphasis in society, literature, the plastic arts, and political deed. These changes-at least in retrospect--indicated the fateful conflicts which were to be acted out in the twentieth century. Mass politics, the appeal to both universalistic and nationalist aspirations, increasing uncertainty about utilizing the fruits of empirical science; all of these uneasy social features pressed upon the German governments. Within this fearful narrowing of pursuits in the face of broadening possibilities, characteristic political movements were--and are--visible, by the twentieth century emerging as an amorphous trans-political ideolofy: Fascism. In Germany known as National Socialism, this movement shared many perspectives, and itself was at least half aesthetic or religious 
in complexion. Its "roots" were European, but paradoxically focused within specific national boundaries. ${ }^{16}$ However, before fascism may be fully considered it is necessary to evaluate its frequent, but not invariable companion, race hatred, particularly hatred of the Jews.

\section{POPULAR TRADITTION AND ANITI-SEMITISSM}

Fear, envy and hatred of the Jews has been a nearly constant feature of European society, but it acquired its contemporary virulence only since the national transformations following the French Revolution. The quality of xenophobic fear before that time, occasionally rabid and violent, was less clearly defined and much less a source of major political consideration. The ancient problems of survival for the Jewish people seemed to be substantially solved by their Roman dispersal over the Mediterranean area. However, with the Christianization of the West, the Roman Catholic Church's attitude, as well as more customary Volk patterns representing the "stranger", helped keep alive antiSemitism.

The medieval period romanticised by nineteenth century cultural authorities was a time of uneven treatment of the Jews. While they were expelled from the Iberian peninsula and periodically were persecuted in many of the German central European cities, in Eastem Europe the Jews were frequently accepted as colonists. They helped to secure:

${ }^{16} \mathrm{Cf}$. , Nolte, Three Faces of Fascism: Action Francaise, Italian Fascism, National Socialism. 
the ruling group's interests against indigenous rural populations. Often skilled in financial and handicraft occupations, Jewish populations generally were useful to ruling secular and ecclesiastical powers, frequently serving as the agents of, or at least the mediators for, political control. Thus the double function of Jewish despised usefulness came to be accepted in much of Europe. In times of prosperity, perhaps Jewish populations were more readily able to adopt the customs of their "host" nations. Frequently, however, it was the Jews themselves who saw a need for securing group identity; often they were satisfied with segregation into Ghetto areas with special governing structures. Thus, Jewish consciousness as a special ethnic group had an historical basis and became a problem mainly in times of hardship when Jews could be singled out to expiate such calamities as wars, plagues or famines.

An extensive mythology about the "wandering Jew," the "Jewish money-instinct," etc., persisted in European society as did the special denigration of Jews as sexual deviates, as the persecutors of Christ, and as the possessors of demonic powers. While this sort of mythology persisted mainly in rural and eastern Europe, it was present as well in western Europe, and curiously paralleled by Enlightenment rationalism. Frequently the Enlightenment had viewed the Jews with a benign neglect born of scom for ethnic diversity. Often eighteenth century society was content to wait patiently for civilization to overcome such "remnants" as Jewish ethnicity. While Jews were thus characterized as retrograde cultural influences, some Europeans viewed Jews as rather more advanced than the "native" Europeans. Accordingly, such cults as Freemasonry cultivated Jewish "occult" wisdom, while of course 
restricting membership of Jews themselves. The commercial states Venice, England and Holland led the way in easing restrictions on the Jews, and by the mid-nineteenth century barriers to Jewish assimilation were generally eliminated in western Europe.

With the Napoleonic convocation of a Sanhedrin, however, the Jews had begun to gain identification within the needs of modern states. Often they were then seen as subversive agents of democratic and national ideas because of this French sponsorship. While Lessing had praised Jewish talent, nineteenth century Germany continued the Enlightenment double standard: Christian sects might be tolerated as eccentric but kindred aspirations toward the Ideal, but Jewish particularly was held to be unable to "transcend" itself. The anti-Semitism of even such men as Marx (himself of Jewish ancestry if "racial" notions are considered) may be traced to this curious view of particularity impeding universal progress.

For the Jews, the really important change early in the nineteenth century was not simply Napoleon's symbolic appropriation of the Sanhedrin, but the intellectual movements which furnished weapons for late-century anti-Semitism. The linguistic and philological studies of particular Germans such as Bopp, Schlegel and Grimm tended to redefine man iri terms of language, belief structure, and historical achievement. As Folucault pointed out, the increasing direction of these studies toward naticnalistic purposes in the nineteenth century opened up the possibility of a linguistic pre-history, eventually even the notion of Aryan linguistic, then geographic, and finally racial origin. In Foucault's terms, with these late Enlightenment theorizings, man's consciousness fell from a. 
coherent view into all manner of opposing and chaotic speculations. As linguistics considered the differing nature of etmic groups, so did science and philosophy work towards a formulation of evolutionary human history. This process became not simply a physical, but a moral process, in which man and his ethics gained a direction, an 1deology. The general view that race was an important characteristic of man had been current in Europe at least since Montesquieu. Race was associated with different cultural forms and levels, believed to be somehow related to differing qualitative and quantitative levels of civilization. However, through a variety of linguistic and scientific studies, 17 dogmas were created for the popular synthesis of latecentury racism. Two exemplary intellectual influences in this synthesis were Carlyle and Gobineau. However, their positions in themselves were meaningful only for the crude usages made of them, not because of any discoverable internal affinity. While Carlyle may be credited with a clear modern formulation of the role of Heroes and was important in völkisch attacks on modemity, he sought the unification of society through religious salvation and revolutionary action. Gobineau, on the other hand, sought the division of society, the casting-off of less valuable social elements. Daming "degeneration," he marshalled the century's scientific findings behind a total concept of race, but himself remained a pensive aristocrat, concerned most of

17Many books have delt with this topic. A good short surmary is Juan Comas, Racial Myths, The Race Question in Modern Science (Paris: UNESCO, 1951). Well organized and more recent is Louis L. Snyder, The Idea of Raclalism; Its Meaning and History (New York: Van Nostrand Fheinhold Company, 1962). A more detalled account, particularly of French racial thought, is Jacques Barzun, Race: A Study in Supeirstition, revised, with a new preface (1937; New York: Harper Torchbooks, Harper \& Row, 1965). 
all with art and graceful nobility. The influence of these two men's ideas was great, but often viewed through the late-century filters of mass political movements, seldom through scholarly research.18

In western Europe, the emancipation of the Jews spread apace with contemporary Liberalism, and few Jews were restricted in the medieval fashion as to household location, type of occupation, or political franchise. However, in the easterm "Pale of Settlement," the Jews were resented and accordingly remained more distinct as an ethnicracial group. Their skills were not allowed free development, their competition was viewed with growing hatred by the local populations under the direction of increasingly powerful nationalist spokesmen. Within the Habsburg Empire, the Jews--with the Hungarians and the German minority--were among the most Ioyal to the Empire. They owed their social position to continued Vienna hegemony, not to the rising aspirations of the many Empire peoples. In Russia, Poland and the Balkans the Jews, similarly to the case of the Phan erixt Greeks, were, and are, hated as foreign elements. Thus the centuries-long trend of the east providing a haven for dispossessed western Jews was reversed with the nineteenth century modernity and particularly nationalism. Magnified with the technological lag of eastern Europe compared with the west, persecutions in eastern Europe continued to increase until

18 There have been many articles and books written on this subject, but many fail to account fully for the popularization of these men's ideas. A good recent treatment is Alexander Bein, "Der Moderne Antisemitismus und seine Bedeutung für die Judenfrage: 'Antisemitismus' als Wort und Begriff," Vierteljahrshefte für Zeitgeschichte, 6 Jahrgang (1958): $340-360$. 
very modern times.

While Germany's Second Empire lifted the last formal restrictions on the Jews, popular anti-Semitism continued in the late nineteenth century. Examples such as the Passion Play at Oberammergau may be compared to Shakespearean works portraying a Jewish demonic character. However, in the face of the nineteenth century's technological and spiritual challenges, Jewish "destructiveness" became less a physical than a metaphysical issue. The literary convention of the evil Jew, the compupting Semitic influence, etc., often operated on a high level of abstraction. Hannah Arendt, among others, pointed out that by the mid-century, a demonic interest in the occult, in exotic peoples, had produced a vogue in the major European capitals of interest in Jews, homosexuals, and mediums. 19 In Foucault's terms, this may be likenerd to the increasing disarray of the modern mind, where an earlier decadent, de Sade, had searched for increasing instrumentality to overcome alienation. The mid-nineteenth century consideration of the pariahJew image thus paralleled on a literary level the nationally inpurtant developments of such Jewish banking families (as the Rothschilds) and such important Jewish individuals as Disraeli.

Thus, by the latter part of the nineteenth century, an increasingly disparate and exotic intellectual atmosphere existed in westem Europe. The actual conditions of life for Jewish populations, however, seemed comfortably esconced on the "escalator" of nineteenth century

19 Hannah Arendt, The Origins of Totalitarianism, enlarged 8th ed. (1951; New York: Meridian Books, Inc., 1960), pp. 81-88. Arendt explores this as well throughout this quite extensive book. 
progress: integration in ethnic and intellectual terms was manifest in the widening European mastery of the world. For the awakening of full, modern national consciousness on the part of the Jews and their neighbors, one must look to the period of the 1870's and 1880's, when truly modern economic cycles became visible. These tensions revealed the uncontrolled aspects of capitalism which have not been extinguished. Corporate expansion, impersonal business life, financial scandals and the mysterious prosperity-depression cycles themselves seemed to invite conspiratorial theorizing. Summarizing the centrality of anti-Semitism in the German case particularly, George Mosse stated:

German anti-Semitism is a part of German intellectual history. It does not stand outside it. Above all, it became involved with the peculiar turn which German thought took after the first decade of the nineteenth century. German thought became at once provincial, in its search for roots, and idealistic, in its rejection of mere outward progress, in its belief in the irrationality of culture. Here the Jew was the outsider, and if he could at times gatecrash by assimilation in the nineteenth century, that did not fundamentally alter the emerging image of the Jew. Culture was closed to him for he lacked the necessary spiritual foundations. 20

${ }^{20}$ Georie L. Mosse, Germans and Jews: The Right, The Left, and the

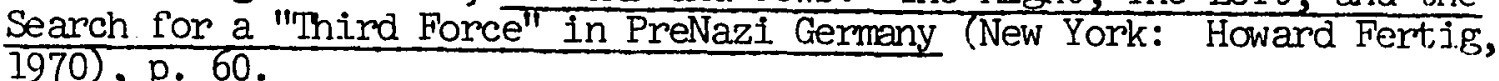


CHAPTER III

RICHARD WAGNER AND THE BAYREUTH KULTURKREIS

RICHARD WAGNER

The Iife of Richard Wagner (1813-1883) spanned the tumultuous mid-nineteenth century. 1 He attempted to create a new form of art, the "art work of the future," to foster a distinctive German art, and to thereby regenerate society. Wagner was early influenced by the Young Germany movement and because of his involvement in the Revolution of 1848 had to flee Germany for a dozen years. From the $1850^{\prime}$ s he was concerned increasingly with a series of educational and aesthetic prescriptions for his contemporaries in addition to writing his celebrated operatic works. While he never lost sight of the day's practical political developments, he worked for a spiritual transformation of man. 2 Winifred Schüler has pointed out that the great influences for developing the Wagner Kreis were the Festspiele idea and the concepts of cultural reform institutionalized by the Bayreuther Blätter and by Wagner's widow, Cosima, in the last part of the century. The combination of these events, however, originated with Richard Wagner's own

IWagner's life is the subject of a great ongoing controversy. Recent works on him and his art are mentioned in Chapter $I$ and in the bibliography.

2This has been convincingly argued by Robert Giddings, "Wagner. and the Revolutionaries," Music and Letters, vol. 45 \#4 (October, 1964), p. 356 . 
ideas, and developed under his careful supervision. The concern with fostering a cultural elite in Germany, with aiding the affairs of the orthodox Wagnerians, centered willingly about him, the Meister, the "charismatic Führerpersönlichkeit" and the Bayreuth Religionsleher. 3

But during mid-century Wagner had found himself paradoxically misunderstood as an artist. His most popular works were the early operas. His long-nurtured Der Ring des Nibelungen was not performed until a quarter-century after he had first sketched it. The technical problems involved in presenting Wagnerian operas in fact have only been resolved with the present day, often nearly a century after they were f'irst encountered. But Wagner's vision of art was shared by a growing coterie of many of the century's leading artists and intellectuals. This group included from the 1840's the musicians Robert Schumann, Franz Liszt, and the young conductor Hans von Bülow. Wagner's musical supporters engaged in bitter debates with critics over the integrity of his creations in an argument which has never ended.

From Wagner's early musical career and his revolutionary deeds there was an intriguing evolution of more abstract and comolex ideas, accompanied by his association with Cosima Lisat Blllow. Cosima was the daughter of Wagner's competitive but sympathetic fellow-composer, Franz Iiszt, educated specifically to inhabit avant garde musical society. From the late $1860^{\prime} \mathrm{s}$, Wagner and Cosima influenced one another, both changing their ideas about religion, art and nationalism. Cosima

3Winifred Schüler, Der Bayreuther Kreis von seiner Entstehung bis zum Ausgang der Wilhelminischen Ara: Wagnerkult und Kulturreform im Geiste volkischer Weltanschauung (Münster: Aschendorff, 1971), pp. 53-54. 
renounced her early allegiance to France and Catholicism; Wagner renounced his ' 48 "revolutionism" and atheism. It appeared that both gravitated increasingly to an at-times discomfitting acceptance of Germany's national role as well as to the new task of institutionalizing his art. For instance, the emphasis of the last-completed Ring operas Siegfried and Die Götterdämnerung appear to reflect an increasing preoccupation with Christian, even bourgeois morality-a circumstance much-remarked ever since. ${ }^{4}$

From 1864 Wagner found a patron in the eccentric young Bavarian king, Ludwig II. While their relationship was stormy, Ludwig never ceased underwriting Wagner's increasingly expensive projects. This was particularly important since Wagner desired to construct his own theater. He refused, however, to build in Ludwig's critical Munich, and instead chose the small Franconian town of Bayreuth, in central Germany. There he worked to construct a Festspielhaus to enshrine his art after the Greek model, leaving for posterity his artistic message. Despite local and Bavarian government aid, Wagner was refused help by the new federal government in Berlin. Instead he organized a series of private subscription campaigns to realize his artistic schemes. The immense financial problems of this endeavor in Bayreuth still plagued Wagner's last years and were the great burden of Wagnerians until at least 1933. Wagner himself was facing ill health, and from 1877 sought to write only one more work of art, an opera purely for display at

${ }^{4} \mathrm{~A}$ vigorous treatment of this problem is Bernard Shaw, The Perf'ect Wagnerite; A Commentary on the Niblung's Ring, reprint of the 4th ed. (1923; New York: Dover Publications, Inc., 1967). 
Bayreuth: Parsifal.

While the Ring was an assortment of music, myth, and interpretive inspiration, Parsifal for Wagner was clearly the summary expression of his art. In it the Germanic Grail Knights were regenerated, led to salvation, by the Christ-like Parsifal. It is critically difficult to separate this work from the last decade of the artist's life. While Wagner had found his art gaining in popularity, he noted this was due mainly to its being misunderstood by the contemporary Bildungsphilister. In a real sense, Wagner himself had been overtaken by the technological and Realpolitik events of the later century. His prized German regeneration appeared increasingly in concrete, not aesthetic terms, perhaps furnishing justification for the fears of a Tocqueville, a Burckhardt, even the young Nietzsche. 5

If, however, Nietzsche made enduring observations in this context of culture which can be separated from the more ordinary needs of late nineteenth century nationalism, a great array of important publicists were often less "elevated" in their criticisms. For example, Paul de Lagarde (1827-1891) vehemently damned the day's materialism and social Darwinism, particularly in his Deutsche Schriften (1886). Julius Langbehn (1851-1907) preached an optimism for the Germanic future if "Nordic" regeneration were to occur. In 1890 his Rembrandt als Erzieher

5 This quite complex problem awaits solution. A good recent treatment of the Wagner-Nietzsche relationship is Robert W. Gutman, Richard Wagner: The Man, His Mind, and His Music (New York: Harcourt, Brace \& World, Inc., 1968), pp. 358-359. 
von einem Deutschen was immensely popular. 6 There were many examples of such cultural criticism, part of which supported the German Christianity movement, and often the conglomeration of Heimatgedanke. In education, justifications for the Realisten against the traditional humanistic Gymasium were based frequently on the need for German technological world power. Lebensreform and Lebensphilosophie were both important in popularizing a new synthesis of social concern. Thus the combination of issue-oriented campaigns and more specifically aesthetic proposals became great causes in Germany.

The varied "causes" embraced by Wagnerians and the Meister himself shared in this vulgarization of philosophy, fostering movements often tinged with more than a modicum of irrationalism. In these latecentury concerns there were visible a few central points of shared value. Increasingly, anti-Semitism was such a touchstone of influence, as was nationalism, popular religion-and Wagner's art. Schüler points out such late nineteenth century ideologies all had a commonality of structure: each jealously guarded a closed ideological aspiration; each was concerned with healing spiritual disunity, reconciling modern man's divisiveness. The views thus centered about this growing "conservative revolutionary" wing of late Wilhelmine society were typically concemed with vitalism, the organic-biological, the mystically known.7

Schüler noted there were three stepping-stones leading to the

${ }^{6}$ The standard account of Kulturpessimismus, focusing on these writers, is Fritz Stern, The Politics of Cultural Despair: A Study in the Rise of the Germanic Ideology (New York: Anchor Books, Doubleday \& Company, Inc., 1965).

7 Der Bayreuther Kreis, pp. 127-148. 
Bayreuth synthesis of anti-Semitism. First was Wagner's publication of Judentum im Musik in 1850 and republication of it in 1869. Second there was Gobineau's formulation of racism and his brief but close association with Wagner at the end of both men's lives. And third was the synthesis epitomized by H. S. Chamberlain at the turn of the century. 8 This progression was anticipated by the actions of the older wagner, when he conceiveu of the Bayreuth institution and set its tone.9 He placed it in the German tradition opposing 1789, with the German Romantics who tended to see nationalism in cultural terms. He reformulated art and national revitalization through the Gemeinschaft of speech, art and morals.

In his Judentum im Musik, Wagner popularized anti-Semitism. He damed the Jews as constitutionally incapable of understanding, or even performing great music. The synthesis of völkisch sentiment popular in Germany owed much to this early formulation by the Meister. His linking ethnic prejudice to artistic and religious aspirations was probably a mid-century attempt to separate his ideal of art from his

$$
\text { 8 Ibid., p. } 231 .
$$

${ }^{9}$ A revisionist scholar of Wagnerism has made the point that Wagner should not have constructed his theater in Germany. He argued that but for this error, Wagnerian art might not have been contaminated by ideology during the German Second and Third Empires. However, this is the very issue at hand: Wagner himself initiated some-perhaps mostof the worst aspects of the ideology which bore his name. The revisionist scholar is Robert Edwin Herzstein, "The Wagnerian Ethos in German History, 1848-1933: A Reinterpretation of Richard Wagner.'s Historical Significance." 
hated critics, from modernity itself. Contrary interpretations of this early booklet abound, but its seminal importance cannot be denied. 10 Wagner claimed the Jews were a non-indigenous people in Europe, who lacked the characteristics of Herder's Volk. Consequently, their speech was always foreign and even Jewish actors were incapable of representing non-Jewish characters. Jews had to simply imitate speech, and therefore spoke with an "audible twang."ll As materialists they further lacked the finely-tuned sensibilities needed for artistic endeavor; their few successes in this realm thus resulted only from their dishonest accumulation of money, not through "personal labor." They recognized only the outward forms, not the inward motivating themes of art. 12 Wagner pointed to Mendelssohn, Meyerbeer, Schumann and Heine as proof's of this thesis. Most important, he stated that salvation for Jews would come only with their ceasing to be Jews. He wrote, "there is only one real form of deliverance from the curse which besets" Jews, "that of Ahasuerus-the 'Untergang!" "13 This word was wisely left untranslated in the English edition of Judentum im Misik. T.t was simply not clear in what sense Wagner meant Jews mist be destroyed or disappear; this could have meant conversion from the religion of Judaism or a physical destruction. Clearly, the only certain interpretation respecting this anomoly would be that at least in 1850 Wagner's

${ }^{10}$ This is cited, for example, in Adolf Hitler, Mein Karmpt, trans. Ralph Manheim (1927; Boston: Houghton Mifflin Company, 1971), pp. 212213.

11Richard Wagner, Judaism in Music, Being the Original Essay Together with the Later Supplement, trans. Edwin Evans (1850, republishted 1879; New York: Charles Scribner's Sons, 1910), p. 13.

$$
\text { 12tbid., p. } 18 \text {. 13 Ibid., pp. 49-50. }
$$


anti-Semitism was far from a biological racial formulation. This vituperative essay, then, despite its ambiguous wording, was an expression of cultural criticism, of nineteenth century anti-Semitism, before Gobineau and true racial determinism. 14

Wagner, to the horror of many of his admirers, republished this essay in 1869. He even added a supplement expanding his condemnation of the Jews, but significantly placed this in explicitly cultural terms. He justified this new edition by noting his critics had adopted the technique of "superior Judaism"; the "systematic libel and persecution" of his dramatic, musical and prose works, all "coupled with a total suppression of the obnoxious Jewish question."I5 Since Wagner himself" had and continued to have important Jewish friends, and since at midcentury the Jews were manifestly in no sense inhibiting the modernization of Europe, the interpretation seems reasonable that in this essay wagner was utilizing the Jews as a symbol.16 Above all what Wagner sought in

14 Der Bayreuther Kreis, p. 234.

15 Judai.sm in Music, pp. 54-55.

16 Herzstein is one of several revisionist authors who argue this point. While this is a difficult issue, I think such arguments allow for temperament and ambivalence more in keeping with Wagner's artistic evolution than does a contrary view of him embodying twentieth century fascism. Another writer somewhat extravagantly stated Wagner's anti-Semitism was:

a principle rather than a practice. By attributing those firces in contemporary Germany which he detested to some agent demonstrably non-German, he was able to keep intact his fetishist belief in the potentialities of the German

'folk.' He detested the meretricious, Frenchified, Italianized opera of Meyerbeer, a Jew; he detested the pseudo-Beethovenian, decadent instrmental music of Mendelssohn, a Jew; he detested the press, scabrous, corrupt, ignorantthe press was largely in the hands of the Jews.

Robert L. Jacobs, Wagner (1935; London: J. M. Dent \& Sons Ltd., 1961), p. 60 . 
this curious work, as confirmed in his numerous other prose works, was the reorientation of social consciousness in a Germany and a Europe which increasingly shared no sense of Gemeinschaft. He needed thus to not only secure his own artistic domination, but to create an audience capable of appreciating it. The difficulties Wagner saw in society led the artist to utilize such programatic mubrics as anti-Semitism-and it is in this nineteenth century context his original statements should be evaluated.17

In 1871 the first Wagner Verein was organized. Others were soon organized throughout Germany, neighboring countries, and in sucn nonEuropean areas as Cairo, Egypt. In 1872 Wagner laid the cornerstone for the Festspielhaus, and unified the various groups under the Allgemeine Bayreuther Patronatsverein, which helped finance the opening, of Bayreuth for the 1876 Ring cycle. However, financial problems plagred this first performance, in spite of the attendance by Europe's nobility and the acclamation of Wagner as the pre-eminent contemporary German operettist. A "Prince's Gallerry" was reserved for Kaiser Wilhelm I, 18 Dom Pedro II of Brazil and Ludwig II as well as for numerous lesser nobility. The musicians Liszt, Tchaikovsky and Saint-Saëns as well attended. Afterward there remained, however, a 120,000 mark debt, and

17 This, however, has obviously not always been the case in the examples of either Wagner or Chamberlain. Much of the entire debate over the nature of even National Socialism devolves about the definition of words and changes in connotation over the last century.

18 The elder wilhelm was, however, entirely unsympathetic to Wagner and stayed only for the first two Ring operas, leaving to attend military maneuvers. Robert Edwin Herzstein, "The Tragedy of Richard Wagner," Arts and Sciences, New York University (Winter 1965), p. 27. 
Wagner launched a Iondon concert tour to help defray these expenses. In 1877 he founded a second Verein, this time dedicated to the projected Parsifal. This was intended not simply to be an artistic celebration, but a religious ceremony, a Buhnerweinfestsplel. Also in 1877, the wealthy Prussian Hans von Wolzogen took up residence in Bayreuth as editor of Wagner's house organ, the Bayreuther Blätter.

It is this period from 1877 to Wagner's death in 1883 that curious and far-reaching developments occurred in Wagnerism. As mentioned, Wagner began his last and most mysterious dramatic work, redoubled his financing efforts, and began publishing his Bayreuther Blätter. Apparently Wagner knew his heart was weakening; it was with a sense of urgency he worked during these last half-dozen years. He had built a sumptuous mansion in Bayreuth from which his artistic affairs were to be directed, Villa Wahnfried. Those select initiates who gained an audience with Wagner and his wife were the inner members of his Kreis. They often referred to not simply Bayreuth as the center of artistic endeavor in Germany, but to Wahnfried, designating the highly personalized influence of the Meister and the Meisterin.

During this time Wagner wrote a series of increasingly violent articles for the Bayreuther Blätter. The very titles indicate the directions in which his thoughts were moving. In 1879 he wrote "Wollen wir Hoffen?" and "Über die Vivesektion," in 1880 "Religion und Kunst" and "Erkenne dich selbst," and in 1881, "Heldentum und Christentum."19

${ }^{19} \mathrm{All}$ of these articles were tinged with more than usual wagnerite venom. They centered about the need for "regeneration," but the actual linkage of their goal and their social presciptions was often far removed from common understanding. They culminated in the essay "Heldentum und Christentum" in the period when Wagner was most affected 
These articles damned the democratic movements of the century, the philistinism of the educated classes, the inadequacies of popular morality. In these articles he endorsed as antidotes vegetarianism, anti-vivisectionism, and the more transcendental influence of his own art. To free man from the Jewish, liberal and material curses of the day Wagner saw his own apotheosis in Bayreuth of prime importance, the supreme effort in the struggle for man's salvation. In this concern it is hardly possible to extricate the personal, egotistical motives from the idealisn of the artist's overall objective. However, to his contemporaries, the Meister's words--often incoherent, ill-chosen, even later repudiated -were frequently interpreted literally.

In this late period of the artist's life, he met Arthur de Gobineau, with whom he had the greatest personal affinities zased on both men's respect for aristocratic will and their contemporary hatreds. However, Wagner's above-mentioned racism was already formulated by 1850; Gobineau's Essay sur I'Inégalité des races humaines only saw publication between 1853 and 1855. The two had met briefly through a mutual friend in Rome in 1876, but became interested in one another mainly in a later, extended visit in Venice, and at Wahnfried. In May, 1881, the Count

by Gobineau and his own creation, Parsifal. In this essay Wagner cited the racist count and compared art to racial factors. He observed that Heracles and Siegfried were central to the formation of morality; one may not think evil of them, since they epitomized truly free man. He emphasized that racial mixtures could not be permitted. The only race which he believed able to produce genius was the white race, and if the Christian martyr spirit were to be added, man might achieve a pure, ult imate salvation. The surmary focal point for Wagner was the "warrrhaftige aesthetische Kunstblüthe" which all great artists he believed had possessed; this pinnacle of struggle, pain and success, he stated, would be realized in his work at Bayreuth. Richard Wagner, "'Aus führungen zu Religion und Kunst.' Heldenthum und Christenthum, "Bayreuther Blatter,' Neuntes Sttck (September 1881), pp. 252-258. 
was Wagner's guest for several weeks, and later in the spring of that year he again visited with the Wagners. Gobineau and Wagner appear not to have explored the sensitive question of creativity since their philosophies remained far apart in this area. 20 But the "heroic pessimism" Gobineau insisted upon appears to have been reflected in the abovementioned series of Bayreuther Blatter articles Wagner wrote during this time. It appears the two could agree on the tenor of their cultural criticisms, even if their theoretical substructures remained quite opposed. 21

The Count's death in 1882 was a great shock to Wagner, and soon after the premier performance of his long-awaited Parsifal, Wagner also died, early in 1883. Now the pattern of dogmatization continued within Wagnerian ranks. While Cosima herself was distraught, even attempting suicide, she set a cultic tone much-remarked in the late century. A great ceremony was made of shipping Wagner's body from Venice to Bayreuth, greater than that accorded most monarchs, and numerous artists assisted in this last pilgrimage to Bayreuth. Cosima cut off her hair and placed

${ }^{20}$ The following rather light handling of this situation illustrates the problem which the two appear not to have broached. As an amateur artist, Gobineau made busts of Valkyries and added to the lustre of Bayreuth. Gobineau assumed creativity could only come from a mixture of the Europeans with primitive "races." Barzun noted, "The vision of Wagner and Gobineau implicitly agreeing in the Villa Wahnfried that Wagner must be more Negro than Nordic gives the story of their friendship a much-needed touch of comedy." Jacques Barzun, Darwin, Marx, Wagner: Critique of a Heritage (New York: Anchor Books, 1941), p. 2.79.

$2 I_{\text {It }}$ is hardly surprising that the creator of the Ring could be attracted to the Count's all-encompassing explanation of degeneration. The devotees of Bayreuth certainly saw the kinship between the two artists, and sought to further its development. 
it on the corpse. She wore mouming black, usually complete with a veil, for the remainder of her life. When the first wreath to arrive at Wahnfried was found to be from Johannes Brahms, Cosima said, "We shall not acknowledge it" because "he did not love the master's music."22 For the next 47 years she was central in shaping and guarding the Bayreuth tradition, which perhaps ended up--in Shavian terms--being more Wagnerian than Wagner himself. Huneker termed her "Cosima I" of Bayreuth, and her stern, humorless rule extended from the overall conduct of performances down to strict patterns of enunciation and gesture for the singers.

COSIMA AND THE INNER KREIS

Cosima herself was a remarkable woman. A powerful personality, she retained a mystic identification with religious ritual, art, and the day's myriad social issues. In Richard Wagner she had found a new and higher law; as the Meisterin she accepted his thought and his apotheosis as the Meister of the entire world. It is particularly due to her inf'luence that the characteristic mixture of Christian-Aryan mystical ritual was united with Schopenhauerean Mitleidsphilosophie in Parsifal. It his been theorized she indulged the sybaritic tendencies of Wagner; certainly from 1865 she was seen by Wagner's friends as the "delphic Oracle."23

22Wallace Brockway and Herbert Weinstock, Men of Music: Their Lives, Times, and Achievements (1939; New York: Simon Shuster, 1950).

${ }^{23}$ Cosima replaced as medium the singer Malwina Schnorr, who had previously served in this capacity for the Meister. Richard Wagner: The Man, His Mind, arıd His Music, p. 273. 
While asleep she had spouted Wagner's social criticisms, and when awakened, remembered nothing. It has been inferred she bargained for powers over Wagner through his psychological weaknesses. 24 In her person was to be united the mythic character of Richard Wagner, more than mortal, only less than divine. While she shared, perhaps even exceeded, Wagner's passionate hatreds, she had a more highly developed sense of bourgeois propriety. For instance, she did not doubt the truth of his Judentum im Musik, but considered its republication in 1869 "an indiscretion."25 Also, the antics of Wagnerian artists who helped stage the 1876 Ring shocked her sensibilities as well as those of the staid Bayreuth citizens. The leadership she gave after 1883 allowed no such levity to infringe upon the seriousness of Wagnerian art. 26

Cosima had a central role in recruiting such supporters of Wagnerism as Friedrich Nietzsche (1844-1900). When Nietzsche was a frequent visitor with the Wagners (1869-1874), he saw himself as an enthusiast of the Meister as well as a tutor for her. The Wagners had hopes of using such academic men as Nietzsche to further their own aims in Germany; the break with Nietzsche was, accordingly, a painful and

${ }^{24}$ Toid., pp. 254 and 273.

${ }^{25}$ Ibid. , p. 301.

26 These "Chancery Boys" included Felix Mott1, Hermann Zumpe, Anton Seidl, and Joseph Rubenstein. They not only helped perform the 1876 Ring but as well supported the declining Wagner. They soon learned, however, to stay away from social evenings at Wahnfried because of Cosima's animosity. She made changes in the operatic performances at Bayreuth, and was only prevented from making more changes by Wagner's own presence. Tbid., pp. 337-342. 
convoluted problem for both the Wagners and for Nietzsche to explain. Particularly, Cosima had hoped to gain Nietzsche as editor for the Bayreuther Blatter. With Nietzsche's apostasy, however, the search for important adherents to the cause continued. It was finally resolved only with H. S. Chamberlain's role and the twentieth century. 27

Another promising academic was tragically lost to Wahnfried, the young Karl Heinrich Freiherr von Stein (1857-1887). The pattern evident here becomes important in considering the story of Chamberlain's Wendung zum Deutschtum. Attempts to enlist academic supporters of Wagnerism were seldom successful by the inner Kreis, although many respected German academics belonged to the various Vereinen and otherwise supported Bayreuth. Stein was a theology student at Heidelberg who became attracted to both the idealism of Schopenhauer and the materialism of Eugen Dühring. 28 He met wagner in 1879 through a mutual friend, and encountered grave difficulties in completing his dissertation and his Habilitationsschrift since increasingly he supported the Wagnerian

27 After Nietzsche's break with Wagner, his sister, married to the notorious anti-Semite Bernhard Förster, remained an intimate of Wahnfried well into the Nazi era. After 1920 she wrote Cosima Wagner "how wonderful [it is] that two women stand at the head of, and to a certain extent represent, the two intellectual tendencies muling the modern world." Ibid., fn. p. 358. The editings of both Nietzsche's and Wagner's writings were problems well into the present day. Only recently have conditions become such that textual revisions may be made and a more balanced view of both men emerge.

28Chamberlain had great difficulty when he helped to write a memorial biography of Stein, since Stein's endorsement of Dühring; and materialism conflicted with his own values. Only with Stein's actual membership in the inner Kreis and subsequent demise was the possibilit.y for this rapprochement secured. Houston Stewart Chamberlain and lriedrich Poske, Heinrich von Stein und seine Weltanschauung; Nebst Heinrich von Steins "Vermachtnis," and ed. (Munich: Georg Muller, 1905). 
ethos. He tutored Wagner's son Siegfried, and fell increasingly under the spell of the Meister's personal magnetism, much as had Nietzsche earlier. Recalled to academic pursuits by his anxious father, Stein attempted to navigate between the attractions of Wagner's romanticism and Dühring's materialism.29 A friend wrote that the hostile, nonWagnerian atmosphere of Berlin "poisoned him." Stein contracted an undetermined illness and died.30 The loss was greatly felt by Wahnfried, and was considered an object lesson of the day's dangerous competing. forces. It was thought philistinism could almost literally kill sensitive adherents to aesthetic causes.

In the meantime, in 1877, the wealthy Prussian Hans von Wolzogen had been selected to edit the Wahnfried publication, the Bayreuther Blätter. Wolzogen (1848-1938) had studied philology, mythology and history at the University of Berlin, and through a further interest in Schopenhauer, embraced Wagner. His fanatical and naive faith was central to his love for the Meister. He sought to create the mystical fundament upon which Wagnerism would prosper. For over half a century he sel fll.essly devoted himself to this task. Guided by Cosima, he sought to further an orthodox Protestantism with the emerging Bayreuth Idea. He was an outstanding example of continuity between the original Wagner supporter's and the Third Reich.31 It was Wolzogen who made such important "discover'ies"

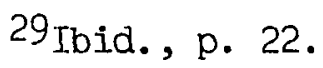

30 Ibid., pp. 52-54.

31 However, just as Hitler found fault with Chamberlain's formulattions of Christianity and race, the Fithrer thought Wolzogen's interpre-tation of Parsifal in terms of Christian-Schopenhaverean philosophy inadequate. He thought Wolzogen was "a blockhead." Der Bayrenther Kreis, p. 216. 
in Wagnerian art as the controversial Leitmotive in addition to his helping blend Deutschtum, Christianity, Regeneration and Art in the Bayreuth Volkspielen.

Another loyal close associate of Wahnfried was Karl Friedrich Glasenapp (1847-1915), a Baltic German, who had studied philology in the Reich. He wrote the standard 6 volume biography of Wagner and worked as well on the Wagner-Lexikon and the Wagner-Enzyklopädie. He was a dedicated worker for the cause, writing articles for the Bayreuther Blätter, even painting a portrait of Wagner for the Riga Verein. In 1902 an attempt was made to secure the Nobel Prize for his biography of Wagner. 32

Ludwig Schemann (1852-1938) was an important supporter of Bayreuth, who--at Richard and Cosima's suggestion-began writing about Count Gobineau. He was to remain close to the spirit of Bayreuth, but became increasingly alienated by Cosima's imperious rule, and by Chamberlain's depreciations of Gobineau. 33 He shared greatly in the late century irrationalism characterized by his friends Lagarde and Konstantin Frantz, and he influenced Noeller van den Bruck (1876-1925). He was a correspondent with Bernhard and Paul Förster, with many anti-Semitic groups, with the Alldeutsche Verband, and himself founded the Gobineau Vereinigung in 1894. Schemarn was thus, with Wolzogen, a link to the later Nazi period. However, even more than Wolzogen, Schemann was a rather traditional Cerman conservative instead of a genuine adherent to National Socialism.

32Ibid., pp. 99-101.

33The outcome of this is described in Chapter VI. 
At his death he, like so many erstwhile "revolutionary conservatives," was sorrowful at the Nazi development of Deutschtum. Schemann thus remained an integrative middle point between the personalities and the influence of Cosima Wagner and Wolzogen.34

Henry Thode (1857-1920) is the last member of the inner Kries to be discussed before the figure of Chamberlain. Thode studied cultural history and worked all his life as an academic scholar. He married Cosima's daughter Daniela von Bülow in 1886, and devoted his efforts to the Wagner family and Wagnerism. His professional career accordingly was made somewhat difficult, but he held a succession of teaching and administrative positions before retiring to write in 1911. This juncture coincided with his separation and divorce from Daniela, thence from Wahnfried, but his contribution to Renaissance scholarship and to aiding the Bayreuth Idea remained. Thode criticized modem decadence, the traditions of naturalism and symbolism and individual egotism. He depicted cultural cycles in history, which included Kant and Schopenhauer, Goethe and Schiller, Beethoven and Wagner. Schuler terms his scholarship a mixture of good research and weltanschaulich dogmatism, of facile organization with rigid theoretical schema. He and Chamberlain never were compatible personalities, and after $1900 \mathrm{fell}$ into increasing hostility. 35

${ }^{34}$ Der Bayleuther Kreis, pp. 101-107.

35Ibid., pp. 107-112. 
WIDER ASPECIS OF THE KREIS

A great many Wahnfried friends were members of the nobility. As mentioned, Ludwig II of Bavaria (1846-1886) was an important figure, as was to be Kaiser Wilhelm II (1859-1941). Prince Max von Baden (18671929), diplomat and Chancellor in the last days of the World War, was also a good friend of Wahnfried, as were many of the lesser Cerman nobility. Czar Ferdinand of Bulgaria (1861-1948) as well as many foreign nobles and aristocrats supported Wagnerism. Many people helped Wagnerian art, often working in the many Vereinen and publishing in the various Wagnerian journals. These men included the Viennese Engelbert Pemerstorfer (d. 1922) publicist influential in that city's cultural life 36 and the brothers Bernhard Förster (1843-1889) and Paul Förster (1844-1925) who worked with anti-Semitic movements including the antiSemitic Petition of 1880 and many educational reform movements. 37

India scholar Ieopold von Schroeder (1851-1921) gained many of his ideas from his mentor Chamberlain, and was important in publicising the Bayreuth synthesis. 38 Another India scholar close to Wahnfried was

36 A sensitive explanation of the circumstances and the ratiorale of the Austrian Wagner following is given in William J. McGrath, Dionysian Art and Populist Politics in Austria (New Haven: Yale University Press, 1974).

37Bernhard Förster, Nietzsche's brother-in-law, was greatly influenced by the later Wagner articles. He went to Paraguay to found a new German utopia. His brother Paul was important in educational circles and in the anti-Vivisectionist movement. Der Bayreuther Kreis, p. 142.

38 His main book expounding the pre-war vogue of Wagnerism, described below in Chapter VIII, was Leopold von Schroeder, Die Vollendung des arischen Mysteriums iri Bayreuth (Munich: J. F. Lehmann, 1911). 
Paul Deussen (1845-1919). Many supporters of Bayreuth were educators, editors, and scholars and as such exercised enormous influence in Wilhelmine Germany. Also, a great number of theologians were Wagnerites, including such men important in the German Christianity and Nazi movements as Friedrich Anderson (1860-1940) and Adolf Bartels (1862-1945). 39

However, most of the men cited above did not live to see the Nazi revolution. Schüler made the sociological observation that the earliest and the third generation of Wagnerites were often the most dedicated and far-reaching in their worship of the Meister. The intervening generation--up to the World War-was less "fanatic"; the enthusiasm of the earlier generation was rekindled with their grandchildren, the Nazi-era Wagnerites. 40 But in the 19th century, the "pilgrimage to Bayreuth" was nearly a paradigm for cultured Western men, not simply Germans. The best examples of foreign adherents came from Spain, Italy, Scandinavia, Russia, France and England, for which the case of Chamberlain is illustrative. In France, such well-known artists as Charles Baudelaire, Stéphane Mellarmé, Paul Verlaine and Maurice Maeterlinck supported the Meister, as did the publicist Eduard Dujardin (1861-1949). 41 In Frgiand, the London Verein, the United Richard Wagner Society, had as president the Earl of Dysart and later the music critic and director, Edward Dannreuther. Arthur Balfour (1848-1930), later Prime Minister and

39Der Bayreuther Kreis, p. 158.

40The middle generation up to the World war was the most representative of the Cerman scientific and cultural comminities. The enthusiasm of the earliest generation was reborn with a quite contemporary vengeance with the war experience, and is discussed in Chapter IX. Der Bayreuther Kreis, p. 167.

41 Ioid., pp. 170-172. 
English Foreign Minister, was as well a friend of Cosima and guest at Wahnfried. 42 The music critic Ashton Ellis was a Wagnerite, and Bernhard Shaw (1856-1950) as well was an adherent, albeit with increasing reservations, who published a still-important book on Wagnerism. 43

The organizations supporting Bayreuth were continued after the Meister's death. In 1883 the overall direction was streamlined to confront the financial tasks which lay ahead. By 1891 the central group was comprised of 100 German branches and 50 associations outside the Reich, totaling 8,000 members. As well, there were many Akademische Wagner Vereine and kindred organizations. In 1909, for example, a Richard Wagner-Verband deutscher Frauen was founded in Leipzig, which gave scholarships and raised money for Bayreuth. By 1913 it had 44 local groups, thousands of members, and had contributed about 150,000 marks to Wagnerian causes. 44

There was visible a hardening of Wagnerian dogma by the years 1890-1896. Wolzogen wrote that with the end of these years the literary period of Wagnerism was closed; what remained was simply the popularization of the Bayreuth Idea. 45 This Weltanschauung synthesized of art, religion and Deutschtum increasingly was a useful tool in the Second

${ }^{42} \mathrm{Balf}$ our, while enthusiastic about Wagner, never learned enough German to study the Meister's works. Accordingly, he was disparaged by such representative Wagnerites as Cosima and Chamberlain. "Houston Stewart Chamberlain: Prophet of Bayreuth," p. 489.

${ }^{43}$ The Perfect Wagnerite.

${ }^{44}$ Der Bayreuther Kreis, pp. 61-62.

${ }^{45}$ J.bid., p. 73. 
Empire's struggles against the modern forces of liberalism, "Judaism" and "materialism." It particularly came to endorse corporativist notions of social organization, the reorganization of business, farm and craft worker relationships, eventually even a political Führerprinzip parallel to the "totalitarian art" of Wagner. But a variety of lesser reifications were also associated with this drive for German regeneration. These came to include opposition to student dueling, "American materialism," alcoholism, excessive luxury, bullfighting, fox-hunting, cockfighting, excessive eating, degenerative dancing, even protective medical imunization and "Roman law." The list of causes which Wagnerites supported included "hygenic" reforms such as gymnastics, tax reform, colorial expansion, school reform, and campaigns to "purify" the German language. 46 The tendency to concretize dissaffection visible in these myriad "causes" was no mere invention of Wolzogen and Cosima, however, Wagner himself, since at least his brief stay in Paris in the 1840's, had combined contemporary measures with his aesthetic program. fror instance, in Paris he had protested what he saw as the commercialization of the theatre, the "empty" virtuosity of individual artists, and the amusements desired by the public. Indeed, the Wagner oeuvre was itself the source from which great amounts of "unreflektierte ideologische Schlagworte" could be drawn. 47

In 1884 a Bayreuther Blätter article, "Die Musik als Ausdruck," by a Graz enthusiast, Friedrich von Hausegger (1837-1899) advocated broadening the notion of art to include Schopenhauerean insights in

46.This is a partial list given in Der Bayreuther Kreis, pp. 189-190.

47 Ibid., pp. 191-192. 
"expression." He thus developed the theme much-discussed to the end of the century, of ideological art. While the actual Bayreuth performances remained fairly standard under Cosima, in line with her conservative and formal aesthetic ideas, the interpretations made of them increasingly embraced Hausegger's rather banal "Ausdrucksästhetik." From this identification of art with Geist, "it was only a small step to the v8lkischNationalist mystification and the domination of Weltanschauung" of the Third Reich period. 48

The Wahnfried task was very difficult before the World War. Financial problems were never entirely resolved, and without the contributions of the Richard Wagner Touring Company, franchised to the empressario Angelo Neumann, Bayreuth might easily have ceased being an artistic center. 49 Undoubtedly it was Cosima's careful management of' every facet of the Bayreuth enterprise which kept temperamental artists and financial matters functioning at all. As might have been expected, she relied wholly on the claim she knew the Meister's intent better than anyone else. Her directions were, therefore, inflexible. She tended to stultify the performances, to create an image of Wagner the uncompromising and unalterable Total Artist. She even unsuccessfully attempted to influence the Reich Government to gain special protection for Parsifal. But with the expiration of the 30 year copyright on this opera in 1913, even a petition effort including 18,000 names failed to bend the Reichstag to favor Bayreuth. 50 Cosima herself had a breakdown in 1906 ,

${ }^{48}$ Ibid., pp. 193-198.

49 Men of Music, p. 444. 50 Der Bayreuther Kreis, p. 75. 
from which time she was increasingly debilitated. Her son, Siegfried, took over the direction of Bayreuth, and for the last decade of her life she was virtually separated from the world. She died, 93 years old, in 1930, only 6 months before her son Siegfried, on the very threshold of the third generation of the Bayreuth Kulturkreis. 


\section{CHAPTER IV}

\section{CHAMBERLAIN'S YOUTH}

\section{5-1879: ENGLAND AND FRANCE}

Houston Stewart Chamberlain was born on September 9, 1855, at Southsea, England. His parents were of upper class English society, who had large real estate holdings, railway and manufactuming investments and generally saw their sons pursue careers in the military. The Chamberlain family had furnished a distinguished line of English patriots, a circumstance never forgotter by Houston. While Houston was the youngest of three boys, and inherited perhaps less than did his brothers Henry or Basil Hall Chamberlain (1850-1935), he never was forced to work for a living. Free to engage in the cultural and intellectual pursuits of the "better classes," Houston was to become fluent in the major European languages. He was conversant with French Symbolist literature, and was at least aware of the major contemporary artistic, literary and philosophical movements in European society.

His mother, Elizabeth Jane Chamberlain, died within a year of his birth. She was to be a subject of great interest for him. He became convinced she was distantly related to not only Scottish and French families, but also to Germans in Lübeck and to Danes.1 She spokc German,

In 1902 Chamberlain related that while sitting for the portraitist, Franz Lenbach in Munich, Lenbach became "certain" Chamberlain issued from at least Scandinavian, not English stock. In particular, to verify his 
and (thus in line with Houston's racial theories) provided for Houston some of the reasons for his mastery of German and his claim that eventually it was nearly impossible for him to enunciate the English "th" or " $w$ " sounds, making them instead "t" and "v." Later Houston was to claim he had entirely lost his faculty for speaking English.2

The Chamberlain family was indeed distinguished, and, as Houston stated, they were not simply English, but Norman, Anglo-Saxon, Celtic, "and other nordic variations of race."3 The matemal grandfather was Captain Basil Hall (1788-1844) who published narratives about the Lütschu Islands off the southern coast of Japan and numerous travel narratives about Europe and North America. He was mentioned with favor by his correspondent, Thomas Carlyle, and by Sir Walter Scott, with whom he was friends. 4 Captain Basil Hall's father, Sir James Hall, Baronet (1761-1832), was a friend and fellow student with James Hutton. He wrote

visual impression, Lenbach produced a portrait of the famous Norwegian explorer Nansen, and then proclaimed, "There is your relative!" Houston Stewart Chamberlain, Lebenswege meines Denkens (Munich: Bruckmann, 1919), p. 22. One of Chamber'lain's biographers reported mailing a photograph of the author to a devoted reader who then responded, "The man is certainly not an English type! If I am not mistaken he issues from the Scandinavian type." Ieopold von Schröder, Houston Stewart Chamberlain: Ein Abriss seines Lebens, auf Grund eigener. Mittel lungen (Munich: J. F. Lehmann, 1918), p. 37.

2Chamberlain to Lord Redesdale, December 16, 1908, from letters at the County Record Office, Gloucester, in Colin Holmes, "Houston Stewart Chamberlain in Great Britain," the Weiner Library Bulletirl, 24, number 2(1970): 32.

3Lebenswege, p. 11.

4"Houston Stewart Chamberlain: Prophet of Bayreuth," p. 2. 
with some authority about architecture and geology and was even known to the young Napoleon Bonaparte during a stay at the Brienne military academy .5

The paternal side of the Chamberlain family was also distinguished. Houston's grandfather, Henry Orlando Chamberlain (1773-1829) was a bastard son of the Earl of Westmorland, related thus to Richard III and the Plantagenet line. ${ }^{6}$ Henry Orlando Chamberlain's activities included working for the Portuguese government, and serving as ConsulGeneral to South America in Rio de Janeiro. In 1826, when civil war occurred in Portugal, he was the main advisor to the English government and was influential in the Canning interventionist policy. 7 He had varied interests in astronomy and botany, and was a particularly valuable source of inspiration for Houston, "a fascinating outline of personality." 8 He had been awarded a baronetcy in 1828 and the title passed to Houston's father, Charles William Chamberlain (1818-1878). Field described him as "a well-intentioned but limited man"9 who spent his life in the navy as ship commander, Admiral, $C$ ommander of the port. of Chatham and later of the port at Devonport. He was in the Crimear War when Houston was born, and sought to direct his sons' lives towark

5Sir James' son later met Napoleon at St. Helena in 1817 and Napoleon recalled James Hall as being a good mathematician, and a person who lived "unforgettably" in his memory as the first Englicishman he had seen. Basil Hall, introduction by Sophy Hall, "The First Englishman Napoleon Ever Saw," The Nineteenth Century (October, 1912), pp. 718-731.

6Lebenswege, pp. 15-16.

7"Houston Stewart Chamberlain: Prophet of Bayreuth," p. 3.

$8_{\text {Lebenswege, p. } 18 .}$

9"Houston Stewart Chamberlain: Prophet of Bayreuth," p. 4. 
military careers in keeping with the family tradition. Admiral

Chamberlain had the examples at hand of his own four brothers who had distinguished themselves in the army. One was a Colonel, one a Lieutenant-General, another a General, and one a Field-Marshal. The lastmentioned was particularly close to Houston; Sir Neville Bowles Chamberlain (1820-1902) distinguished himself in India and was honored in England during his retirement. His death severed nearly the last family link Houston valued to his homeland. 10

The plans of Admiral Chamberlain for his sons' careers were in each case ruined. Only Henry served briefly in the navy, but was invalided home and went into business. Basil and Houston were adventurous rebels against the family traditions. Basil was considered the bookworm and the f'amily intellectual, at least until Houston went to the Iniversity in 1879. Basil studied at the Sorbonne and Oxford and journeyed to Japan. He became Professor of Japanese literature in Tokyo, wrote travel-guide books and edited many editions of Japanese and other oriental literatures. Basil was a cosmopolitan literary critic; he supported Houston's own publishing efforts, returned to retirement in Europe in 1911, and died in Switzerland in 1935.11

${ }^{10} \mathrm{An}$ interesting account of this man is G. W. Forrest, Fie].dMarshal Sir Neville Chamberlain (Edinburgh and London: William Blackwood and Sons, 1909) which confirms Houston's own account of this famous uncle. It does not, however, refer to the Field-Marshal's criticism of British policy in the Boer War, as suggested vehemently by Houston.

IlBasil Hall Chamberlain was an informed "good European" in contrast to his brother Houston. An agnostic in his early years, he still defended the role of the Catholic Church in European historm and ultimately joined, then left the church. He delighted in reading. such authors excoriated by his brother as Heine and Tolstoy, and he 
When the Chamberlain boys' mother died in 1856, Henry and Basil were older and already becoming adjusted to English life. They spent more time in England than did Houston, and never suffered the estrangement from their native country that he did. The boys were sent first to live with a paternal grandmother in Versailles, Lady Anne Chamberlain (d. 1869) who was Sir Henry Orlando Chamberlain's widow. Lady Anne's urmarried daughter Harmiet Chamberlain (d. 1899), also lived at the Versailles house, and she became a second mother, particularly to the young Houston. The pattern of attention to the youngest boy by the well-meaning female relatives probably had an adverse long-term effect upon him. He was later to refer to his paternal grandmother as too inclined to not discipline him ${ }^{12}$ and Field suggests the Versailles household did not promote maturity in the young Houston. 13

While Henry was enrolled at a military school in England and Basil attended the Iycee Imperial in Versailles, for the better part of the first ten years of his life Houston stayed in the household. Attempts to enroll him full-time in the Lycee failed as his health was poor. He was encouraged by the doctors to take long walks for the purpose of

decried racism. He was critical of nationalism, believed revolutions and militarism alike were despicalle, and prized the cultural contributions of Germans. However, during the First World War, Basil remained a supporter of the Entente, and as well sought to placate his brother Houston. Published volumes of correspondence are Basil Hall Chamberlain and Lafcadio Heam, Letters from Basil Hall Chamberlain to Lafcadio Hearn, compiled by Dazuo Koizumi (Tokyo: The Hokuseido Press, 1936) and Basil Hall Chamberlain and Lafcadio Hearn, More Letters from Basil Hall. Chamberlain to Lafcadio Hearm, compiled by Dazuo Koizumi (Tokyo: The Hokuseido Press, 1937).

${ }^{12}$ Lebenswege, p. 164.

13"Houston Stewart Chamberlain: Prophet of Bayreuth," pp. 9-10. 
strengthening his body, but suffered recurrent illness all his life. However, at critical points in Houston's life it appeared that the nature of his disability was predominantly psychosomatic. Field, for example, takes the sensible position that indeed Houston's health was a constant concern, bringing him close to death several times, but it was aggravated by the failure to correctly diagnose and treat his real probilem: a nervous condition. Increasingly debilitated in later life, Chamberlain was prevented from working. However, he was seldom slowed from a demanding writing and social schedule, and never diminished his preoccupation with the world of the performing arts.

In 1866 Admiral Chamberlain attempted to direct Houston in the desired professional path by insisting his son be enrolled in an English boarding school. Houston suffered from the contrast between his life at Versailles and the activities of rowdy peers in the English environment; he was very homesick for France. Houston never forgot the shock of this: experience; his works contain references to the barbarism of a school established only to make money, full of raw knaves who delighted in mistreating younger students. He stated a teacher was charged with indecently assaulting a student, and compared the school to accounts in Dickens' Oliver 'Twist. 14 His anguished letters to his father by the next summer eamed his transfer to the larger and more prestigious Cheltenham College. This school stressed the Anglican influence paraIlel to the Rugby reforms made by Thomas Arnold. The moral tone of the day's English Public School has been characterized as a time when "one undergraduate had to prepare another for the news that a third ${ }^{14}$ Lebenswege, pp. $37-38$. 
undergraduate had doubts about the blessed Trinity."15 At Cheltenham College Houston found wider opportunities for introspection and was encouraged in pursuits apart from his fellow students. These early influences were important to the later development of his aesthetic, philosophical and political views. He wrote,

I remember the period of ardent and absolute faith in the religion I had been taught. How unspeakable was the joy of recollecting when I woke in the morning, that Christ was there, near my bed, and that he loved me. How delightful the evening prayers in the college chapel, the prostration before God in the half-darkness, broken only by some few, flickering gas-flames, and whilst the monotonous chant of the responses rose up on alternate sides. Perhaps I was not very orthodox, even then,-for I rarely listened to the service; ny child's mind was filled by the actual presence of God, and I used to continue repeating between my lips: Oh Jesus, I love thee, I love thee, I love thee! And then I would pray to Him to love me; and when I had the conviction that He did, then I was more happy than words can say, and at night my friends the stars, glittered more brightly than ever. But gloom always soon came over this image; the remembrance of the daily miseries of school life, on the ever-fretting dependence of a child on the will of others. 16

Houston disliked Cheltenham, but was forced to tolerate it. Also, with the death of his grandmother Anne in 1869 the Versailles house was sold, and now the boys spent their holidays with nearly-unknown relatives in England. It appears that he suffered from the different linguisticcultural environments as well, and was generally thought of as a f'oreigner. He stated that he was rebuked in England for his French handwriting, and the reverse occurred in France regarding his English affectations. He claimed the conflicting educational policies of the two nations limited

15G. M. Young, Victorian England. Portrait of an Age (London: The Oxford University Press, 1936) quoted in "Houston Stewart Chamberiain: Iraphet of Bayreuth," p. 12 .

16Houston Stewart Chamberlain, Nachlass (Bayreuth), quoted in "Houston Stewart Chamberlain: Prophet of Bayreuth," pp. 12-13. 
his outlook; he learned separate histories, geographies, and paragons of culture. Later he stated with no sense of irony that as a result he had not a European, but a world view of history. 17 Also, he claimed he had an especially obnoxious English teacher who denied him music instruction, and when he pressed his father to ask about this omission his father was told "What is music for a Man!" Instead, it was suggested either soccer or cricket would be more beneficial. 18

At Cheltenham College the young boy studied Shakespeare intently and would gaze at the stars from a small window in his room. He early formed a predeliction for what may be termed aesthetic-religious values, and pursued these interests rather than the companionship of his peers. For example, having imbibed the liberal political views of his family, Houston at one point found himself wearing Gladstone colors while his fellows championed Disraeli. He was beaten by the others. ${ }^{19}$

His health declined, and in 1870 doctors decided a change in climate would be helpful. They prescribed visits to continental health spas, thus beginning the wanderings of Houston and his Aunt Harriet over Europe. The sojourn developed into a nearly total break with England; from Houston's 15th to his 24th years he journeyed from one Kur to another. In his memoirs Houston maintained the pain of these early years never ended. He said he was kept from enjoying the genuine life

17 Lebenswege, p. 44.

18 Ibid., p. 173.

${ }^{19}$ In an article supporting the German cause in World War one Chamberlain cited this occasion as illustrative of the real caliber of English Democracy: while lip-service might be paid to fair play, such treatment of dissenters exposed the real values of aggressive schoolboys and their parents. In J. M. Robertson, "Herr Chamberlain and the War," Contemporary Review, vol. 108 (1915), pp. 296-308. 
accessible only to true natives of a single country. Even as late as 1916 he reported not being entirely at one with the full potential of life as were life-long inhabitants of Germany. 20 while his brother Basil also spent most of his life away from the British Empire, Basil was always able to draw upon memories of happy life in England, and characterized himself as being a native to "no country but an amused guest in all."21 But Houston, even at the age of 15, saw himself alienated from his family and peers. When he did visit England with his family he was called "the distinguished foreigner" and by contrast he noted that during, the same period, England, for example, was called home by thousands of German immigrants. 22

While Chamberlain loved the French language and held fond memories of his life at Versailles, here too was a source of alienation. His family, while living in France, associated only with Protestants, often professional men and particularly bankers; always they referred to lirance as inferior in greatness to the British Empire. Even upon occasjons of French success and British failure in foreign policy, discussion treated these as exceptions to the rule. For Houston, imbued with PalmerstonianGladstonian Liberalism, the fate of lands such as Ireland and India seemed enviable; at least their inhabitants were secured the blessinn:, of English rule. Resolution of this conflict of English political.

20 Lebenswege, p. 29.

21 Basil Hall Chamberlain and Lafcadio Hearm, More Letter's from Basil Hall Chamberlain to Lafcadio Hearn, compiled by Kazuo Koizuni. (Tokyo: The Hokuseido Press, 1937), p. 109.

22 Lebenswege, p. 30. 
traditions with his emotional reservations about English values was, however, to await the maturity of the young Chamberlain on the Continent. 23

FROM 1870: THE CONTINENT

During the nine years of Chamberlain's wanderings doctors were unable to establish the real cause of his suffering. Only a few brief trips were made back to Fngland where the climate was thought unfavorable. Chamberlain's arrival at Bad Ems in June of 1870 was particularly fortuitous because, as he was later to write, he had seen the events related to the famous "Ems Dispatch." Perhaps he saw the last conversation between the French Ambassador Beneditti and the Kaiser. At any rate, he became fascinated with troop movements of the Franco-Prussian War. The family was not allowed to return to France throughout the early stages of the conflict, and the young Chamberlain was treated to the sight of entraining German troops and the contrasting disarray of captured French troops. He heard the distant bombardment of strasbourg, and when the family was later able to visit occupied Versailles, Chamberlain recalled the impressive parades of Prussian troops; the impact of all this was important in forming his own character. ${ }^{24}$

23"Houstun Stewart Chamberlain: Prophet of Bayreuth," p. 15. There also is a great deal of discussion of family attitudes in Chamberlain's Lebenswege, pp. 35 and 42.

${ }^{24}$ Lebenswege, p. 54. Also, many subsequently printed articles and books referred to this period, e.g., Oskar Doring, Ein Deutscher namens Chamberlain: sein I.ebensbild nach seinen eigenen Worten (Langensalza: J. Beltz, 1937). 
Houston's health, however, had become so serious a matter that family members such as Sir Neville were summoned. But, with his recovery, Houston visited the battle sites and listened to knowledgeable comments by his uncle about the terrain and possibilities of tactical maneuvers. 25

The pattern of his life becane one of moving throughout Europe according to the seasons. He spent the summers in the south of France, usually Cannes, and the winters in Switzerland. He was able to pursue his interests in natural science, observing vegetation and topography, contrasting as they did with his former English and northern French surroundings. These years rich in impressions of nature also afforded contacts with diverse leisured individuals. During the first winter at Montreux, Chamberlain was secured a tutor, the 29-year old Prussjan theological candidate, Otto Kuntze, Kuntze had been sent south for reasons of health, and was giving lectures and private instruction to support himself'. The Chamberlain family had located him via a small note he had pasted on a book shop window, and soon found him an agreeable companion for Houston. Frlarging his instruction from merely the German language to full-time tutorial duties, Kuntze imparted his understanding of Protestant Prussian values to the recuperating young, Chamberlain. They became fast friends, playing chess together and arguing politics. Kuntze aroused Houston's interests in science, history, and philosophy. 'They read political tracts such as Gladstonle's speeches on the Irish question, and 'iranville's telegram communications with Bismarck during, the recent war. Evidently their mutual iriterests:s

25This is recounted, verifying Chamberlain's own accounts, in Field-Marshal Sir Neville Chamberlain, pp. $452-455$. 
in English liberal politics, dislikes of Disraeli's Imperialist policies, and war "experiences" encouraged Chamberlain to seek more information about newly-unified cermany.

Under Kuntze Chamberlain read the French classics, as well as such "Whig" histories as Prescott's Conquest of Mexico and Motley's Rise of the Dutch Republic. 26 The prescribed excursions into the countryside provided him with much information about the flora and fauna of the alpine areas of Europe. Moreover, he was beginning to read the contemporary late-Victorian poets, and religious sources such as St. Faul, Luther, Meister Eckhart and the Brahmans. Chamberlain later wrote that this was an important time as well for his understanding of Shakespeare and that eventually it would be this synthesis of aesthetic studies which--with the addition of Beethoven--would lead him to an understanding of Richard Wagner.

In 1870, Chamberlain had briefly visited Bayreuth, but as yet he had no awareness of the musical tradition he was later to embrace. He recalled seeing during this period the former Wagner house, 'Iriebschen, in Switzerland.27 But his late awakening to the full impact of Richard Wagner was due to his chaotic upbringing--an observation Chamverlain was to make about many aspects of his life. As a child he could read only about French and English music, unaware of "the wonderful (ierman Märchenwelt." Since the one aunt who had any musical training in the f'amily was deaf, Chamberlain related that their attempts to play duets were hopeless. Only when an uncle visiting from India took Houston to see Mozart's Don Giovanni was a feeing for music aroused in him. 28

26 Leberiswege, pp. 315-321. 27 Tbid., p. 179. ${ }^{28}$ Ibid., p. 168. 
Now, however, with Kuntze, music became important for the young Englishman's education and for his perception of German culture. While Field has established that Chamberlain did not really begin to study the prose of Wagner's librettos at this early date (this began in eamest only in the late $1870^{\prime} \mathrm{s}$ ), in his memoirs Chamberlain dates the beginning of his appreciation of the Meister's art from this period with Kuntze.29 The central role of Kuntze seems abundantly clear; though the Chamberlain family had been pro-French at the beginning of the 18701871 war, and Houston determined to master the German language only later, in 1874, the mediating, decisive influence was this tutor personifying Prussian values. 30 While later Chamberlain claimed many lines of influence from his studies of Beethoven, French and Finglish prose and poetry were important for his "inner direction" toward German culture, this seems less important than the immediate, personalized conditions of his life in the 1870's. 31

A motif that appeared throughout all of Chamberlain's later published works that may be explained only within his developinf racial dynamic was his statement that the "eye" mystically perceives relationships and affinities invisible to mere empiricism and "mechanirm." At Cheltenham College, for example, Chamberlain had found his "eye" leading:

29 Ibid., p. 188.

30Ibid., p. 189.

31This opinion was also stated by biographers who desired to show Chamberlain's affinity not for the materialist, parliamentary or "philistine" Germany but for the "Heroic Germany" as in, e.g., Mart, in Dippel, Houston Stewart Chamberlain, in the Reihe Kïnder und Kärmfer series (Munich: Deutscher Volksverlag, 1938), p. 7 . 
him to discover the nightly display of the heavens, sights which were demonstrably purer than the rowdy conduct of his fellow students. With studying Shakespeare and natural science, Chamberlain developed an explanatory mode of the greatest importance for his subsequent development: intuition. Even at this early time he believed he was finding underlying logical patterns in scientific research, in form and purpose, in the variety of nature. Iater united with his growing, affinity for commpted German Idealism, this literary-scientific predilection was used to construct his notion of underlying racist Lebensphilosophie. ${ }^{32}$ Perceiving as he did an underlying continuity between the natural and the Gebildete realms, Cnamberlain later came to interpret philosophy as well in these ideological terms.

However, in May, 1873, Admiral Chamberlain again attempted to direct his youngest son's life toward a career, and therefore recalled him to England. Having abandoned his earlier plan of a military career for his offspring, Admiral Chamberlain now suggested Houston attend an ayricultural college and then begin farming in Canada or India. 33 However, it was evident that Houston's health simply would not permit life in England, let alone in the dominions. Houston was allowed to return to the continent to pursue his own interests and made financially independent. 34

32 Lebenswege, p. 80.

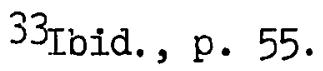

${ }^{34}$ Schroeder, Houston Stewart Chamberlain: Ein Abriss seines Lebens, auf' Grund eigener Mitteilungen, p. 51. 
During Houston's visit to England Kuntze had secured a position as pastor to a German Evangelical community in southern France, and for the following months could only give Houston part-time instruction. But Chamberlain's later studies were still inspired, even reviewed by Kuntze, furthering and deepening his Bildung. 35 When in the fall of 1874 Kuntze returned to Germany to finish his own studies, Chamberlain was well on his way toward mastering German and toward developing his own views of society. Kuntze and Chamberlain were to correspond throughout their lives, and Kuntze read and criticized Chamberlain's manuscripts. 36 Later, when Kuntze had been retired from his duties as a Gymnasium instructor in his home town of Straslund, Chamberlain was to praise him in letters to German newspapers, characterizing him as "a truly Prussian man," self-sacrificing, with many-sided interests. 37

In 1874 Chamberlain met the daughter of a minor Prussian judge, Anna Horst. Older by 10 years, Anna was supporting herself tutoring, Cerman children in Cannes. Through the common interests in natural science and things German the two became acquainted, then infatuated with each other. In her memoirs published during the Weimar Repubiic, Anna described their life together. 38 They first met when the German

35Lebenswege, p. 43.

36 Schroeder, Houston Stewart Chamberlain: Ein Abriss seines Lebens, auf Grund eigener Mitteilungen, p. 51.

37 Lebenswege, p. 56.

38 Though the two were divorced after a long marital crisis and legal negotiations, Anna never ceased admiring Chamberlain. Her book was an attempt to clarify her own role in his success, and was, therefore, a valuable addition to his own memoirs as a blographical source, particularly in revealing their quite expansive life style. 
conmunity in Cannes held a bazaar; Anna recalled being told the handsome young Englishman wearing a huge floppy hat was living with his aunt in a local pension. Securing an introduction, Anna that evening discussed "plants, rocks, and animals" with Chamberlain. 39 Residents of pensions and temporary citizens of vacation places in the scenic coastal and alpine areas adjacent to the Mediterranean then, as today, were swept up in an active social life. Anna described many outings, for example, tours of ruins, dramatic geological expeditions, etc., and the evenings were taken up with the pair joining Aunt Harriet in playing cards or attending concerts. When Aunt Harriet visited England briefly in 1875, Chamberlain was advised by doctors to remain in Europe; he and Anna traveled through southern France and Switzerland. When she took a position tutoring in Switzerland in 1876, Chamberlain decided to involve himself in the Cerman community at Interlaken.

'There was considerable opposition to their marriage in the Chamberlain family. Houston was believed to be marrying below his station since Anna's family had little social standing and no dowry to offer. Anna, however, provided an attentive and imaginative audience. for Houston, and shared his interests. The couple's dispositions were similar, and it has been inferred their neuroses reinforced one another. 40 Despite the age dif'ference and family opposition, with

39Anna Chamberlain, Meine Erinnerungen an Houston Stewart Chamberlain (Munich: C. H. Beck, 1923), p. 2.

40 Michael D. Biddis, "Houston Stewart Chamberlain, Prophet of Teutonism," History Today (January 1969), p. 11. The same comient has; been made by another writer, who also states the quite-remarkable fact that Anna was half Jewish. Neue Deutsche Biographie (Berlin: Durnckrr. \& Humblot, 1957), 3rd. vol.; "Chamberlain, Houston Stewart, Schriftsteller," by Otto iraf zu Stolberg-Wernigerode, p. 458. 
the death of Admiral Chamberlain, Houston was free to marry and did so, three months later, in May, 1878.

Chamberlain was writing prose and poetry even at this age, and Anna is one of the few corroborative sources for much of this otherwiselost material. She reprinted excerpts, and after their divorce in 1908 had many of his early writings retumed to him. He wrote, for example, Iong narratives inspired by Sir Walter Scott; one of these, "Dochárt," dealt with feuding Scottish clans. 41 The majority of these early writings were influenced by the late Romantics and were often melodramatic bombasts as well as adolescent visions of rapture and despair. 42 Chamberlain was not without promise as a writer, and when he sent manuscripts to the Swiss poet Gottfried Kinkel he received useful criticism. 43

In late spring and early surmer 1876 Chamberlain visited Spain with a Dutch friend, Herr Grünewald. His friend was recuperating from illness contracted in the East Indies, but relapsed and died, leaving:

4lDescribed and translated in "Houston Stewart Chamberlain: Prophet of Bayreuth," pp. 33-34.

${ }^{42}$ Characteristic of his efforts during this time was a poem to Anna in Meine Erinnerungen an Houston Stewart Chamberlain, p. 18 ending:

And thou, my sweet one, thou willst with me come, No longer will we dream of Poetry, But Spirit-Poetry ourselves become!

43Meine Erimerumgen an Houston Stewart Chamberlain, p. 17. 
Chamberlain to make the funeral arrangements. This event also affected Chamberlain's health, confirming his family's fears for his health should he be required to return to England or take up a profession. While in Spain, Chamberlain had also written letters to Anna and to Harr.iet which to an amazing extent demonstrated his fondness for things German. Despite the delightful excursion through eastern and southern Spain, the homesick Chamberlain wrote of his love for a Germany he had only briefly visited. As noted by Field, this letter is surprising because it was written by the twenty year-old French and English correspondent, admittedly not yet fluent in German. It did not reappear in Chamberlain's writings in this extreme nationalist form until the time of the Boer War. Indeed, the letter was only published during the first World War, and reflects the sort of contemporary social criticism being made by men such as Lagarde and Wagner, with whom Chamberlain was not yet f'aniliar. It reveals a depth of aesthetic and chauvinist feeling which only in the twentieth century came to fruition. 44

During parts of 1876 and 1877 Chamberlain lived at a German pension in Interlaken, intent upon becoming as familiar with this environment as passible. He described himself as having taken walks, eaten meals, and read newspapers as a veritable convert to German culture. His letters

44 The following letter was written by the 21 yearmold Chamberlain while vacationing in Spain in 1876. It was widely reprinted dur.ing. and after the World War in Germany, drenched as it is with chauvinism:

I cannot tell you how much my reverence, my passionate love for Germany and my faith in her, increases. The more I learn of other nations, the more I mix with people of all classes-educated and uneducated-from all the countries of Europe, the more I love Germany and the Germans. My belief that the whole 
to Aunt Harriet reflected the depth of his continuing transformation, unsure as he was about his future vocation, but highly interested in science, culture and Germany: "God! How I take courage at the absence of English formality: after ten minutes I feel at home with theșe people!" And several days later, in another letter to Aunt Harriet, he revealed his three wishes: to not have to emigrate as a farmer to the colonies, to live instead far from England, and finally to settle in Germany. 45 However, because of medical advice, he continued his seasonal migrations between the French Riviera and Switzerland. He felt so alienated from England that the slightest thought of "Fngland and Englanders makes me unhappy." 46

Financially secure, well-mannered, possessed of the tastes for leisure and culture of the better educated classes, Chamberlain was

future of Europe - i.e., the civilization of the world - rests in the hands of Germany, has now grown to a firm conviction. The German's existence is quite different from that of other men - in hin self-awareness and the feeling of his own worth have reached their high-point. He is both artist and practical organizer, thinker and activist, a man of peace par excellence and the best soldier, a skeptic and the only man who is really capable of belief. But, as always, the greater the natural gifts, the greater the responsibilities which go with them. Germany's role is a tremendously difficult one and if she is to fulfill it, the whole nation must recognize the task and strive together as one for its accomplishment. Not only does Germany have so much to perform and develop, but in the meantime, she must preserve herself against the animosity and misjudgements of all Europe.

Printed in Anna Chamberlain, Meine Erinnerungen an Houston Stewart Chamberlain (Munich: Oscar Beck, 1923), pp. 28-30. "Translated in "Houston Stewart Charrberlain: Prophet of Bayreuth," pp. 26-27.

${ }^{45}$ Lebenswege, pp. 58-59.

${ }^{46_{\text {Tbid. , p. }} 190 .}$ 
an intense but stimulating personality for others he encountered similarly situated in the vacation sites of Europe. He enjoyed friendly contacts with a wide selection of distinguished and artistic men. For instance, a Professor Kussmaul from the University of Freiburg was impressed with Chamberlain's knowledge of natural science, and encouraged him to attend that German university. Obeying medical advice, however, Chamberlain declined the invitation. to leave the Mediterranean for Germany proper. 47 He met as well a retired Prussian general, von Twardowski, at the Interlaken Kur musical performances, from whom Chamberlain gained insights into Prussian life and attitudes. From the general's son, a lieutenant, Chamberlain heard first-hand accounts of the Franco-Prussian War. Another notable was a Dr. Oskar Borchardt from Berlin, an expert in international politics and trade laws who had been in the diplomatic service. Chamberlain accompanied this man on an excursion to the Riviera and back to Interlaken, an experience he credited with helping him perfect his German. 48

\section{MUSIC AND CHAMBERLATN'S JEWISH FRTENDS}

Chamberlain, like Richard Wagner, was able to master the contradiction of advocating general prohibitions against Jews while making exceptions among his own friends. During the early 1870's, Chamberlain found, as did Wagner, important and influential men with whom he becarne fast friends in spite-or because--of their "Jewish backgrounds." Chamberlain seems not to have explained whether his own views had hardened. One can only speculate as to the reasons for these frienrl-

$$
\begin{aligned}
& 47 \text { Ibid., p. } 84 . \\
& \text { 48 Ibid., pp. 190-19.1. }
\end{aligned}
$$


ships, but cosmopolitanism was the apparent result during Chamberlain's earlier years. Living in the Interlaken pension he had befriended a St. Peterburg Jew, Herr Löwenthal, who was an adherent of the Greek Orthodox Church. Löwenthal was by education a German, and had lived as a German language teacher in Paris at the Lycee Louis le Grand. Chamberlain wrote they were close friends, and the death of Löwenthal a few years later was a great loss to him. Chamberlain believed-at least by the time he published his memoirs--him to be of the "Oriental" variety of Jew, i.e., an example of that "mysterious" Sephardic "race" dispersed throughout the eastern Mediterranean area. Chamberlain was later to be particularly fascinated with this stock of the Jewish "race" both in his writings and in friendships. 49 He praised Löwenthal as a f'ine man and a superbly educated example of the Sephardic Jew. The two men shared a common interest: music. Lơwenthal was an accomplished pianist and played many instruments and selections of composers from memory, from Chopin to Gypsy tunes, Schubert Lieder, Weber, and a littile Wagner and Beethoven.50 Chamberlain acknowledged Löwenthal as the marn who enriched his own understanding of music.

Another Jew whom Chamberlain met in Interlaken was a certain Iorr. Bl.umenfeld who lived in Vienna. Chamberlain credited Blumenfeld with imparting to him his first real insights about Wagner. Interesting. I,

${ }^{49}$ Chamberlain develops the theme of mysterious genius in regard to such persecuted peoples as the Sephardim throughout his later. writings, an affinity which has been nuted boarders as well on his concept of the Aryan. Iater, in Vienna, Chamberlain became friends with Otto Weiringer, whose tragic suicide left him distraught in letters to Cosima Wagner. The irony of this will be developed in Chapter VI.

${ }^{50}$ Iebenswege, pp. 15 and 192. 
while Blumenfeld rejected the contemporary Wagnerite praise for the Meister, he acknowledged him as an important artist of music and poetry as well as the dominant figure in music for the latter nineteenth century. 51 The two discussed the first performance of the Ring at Bayreuth in 1876 (a Festspiel Blumenfeld attended) and in his memoirs Chamberlain related--perhaps apocryphally-that he learned of the actual opening of the Festspielhaus in 1876 only through reading the London Times. That newspaper, Chamberlain related, stated Wagner's new theater was being built in Beyrut, Syria, where the "fanatics" of his art would make yearly "pilgrimages." 52

At Interlaken Chamberlain heard Blumenfeld give a lecture on Wagner's music, and wanted to attend the 1876 Festspiel. However, even with his allowance, the price of the journey to Bayreuth, accomnodations, and the high admission price for the Ring performances were more than he could afford. When he appealed to his father for more aid, his father had arswered, "I was crazy," so Chamberlain wrote a letter to the Meister himself at Bayreuth. In keeping with the avowed intention of Wapner to make it possible for impoverished artists to attend his new performances, Chamberlain asked to be admitted to the Festspiel without paying the admission price, promising he would someday make up for this special. consideration. By return mail, however, Chamberlain received only the schedule and price list for the second and third 1876 Ring perfor mances 53

Writing a popular article, "Mein Weg Nach Bayreuth" in 1896, Iater

51 Ibid., pp. 193-194. $\quad 52$ Tbid., pp. 16 and 194. ${ }^{53}$ Ioid., p. 3.34. 
included in his memoirs, Chamberlain began with a quotation from Goethe, "Da wo wit lieben ist Vaterland:"54 This sentiment by itself is noble and in the better (or at least the more favorable) interpretations of Chamberlain redounds to his credit as well; as an Englishman Chamberlain chose another country for reasons of the "heart" or culture. However, as became increasingly apparent during the late nineteenth century, his participation in social movements became confined to determinist and mechanist ideologies, as well as anti-Semitism. His affirmation of aesthetic values was increasingly undercut--though never acknowledged-by a deepening comitment to Deutschtum and racial hysteria. Still, Chamberlain maintained the main impetus toward his adopted country came from the "inward" path through the French and English late Romantics, through Shakespeare, and culminating in the art of Richard Wagner. For Chamberlain, Wagner "can not err"; Wagner, as "The sun of my life" never sets. 55 Chamberlain saw this progression to Wagner not as Romanticism--most particularly not as the feeble sort of Weltschmerz he came to dam in his Vienna years--but as the Architektonik of insight visible to astute observers in, for example, Beethoven's piano sonatas and in Shakespeare's works.56 Chamberlain saw a continuity

${ }^{54}$ Tbid., p. 162.

55 Ibid., p. 162.

56 Ibid., p. 178. Chamberlain saw a continuity between, for. example, the D minor op. 31 and op. 32 and the F minor op. 57 as evidence of the Influence on Beethoven by Shakespeare; he referred the reader to contemporary writers on this subject; for example, Joseph Fembaur, Ludwig Beethovens Sonaten (Munich: 1913). But all of this in Chamberlain's case only made sense when his Lebensphilosophie of racial dynamics was considered. 
between the dramatic Wagnerian "artwork of the future" and Beethoven's last symphony. This Ninth Symphony, with its controversial fourth choral movement, is, of course, the focal point of a continuing debate among musicologists, but the Wagnerian usage of parallel and development with Beethoven does have considerable validity. Even today Bayreuth opens each year's Festspiel season with a performance of Beethoven's Ninth Symphony.

In contrast to many intellectuals of the late nineteenth century who came to Wagner through his librettos, 57 Chamberlain was a young man during this time and first heard bits of music from the early wagner works while sojourning in Switzerland. Particularly, concerts at Interlaken awakened his interests in the Meister, but did not permit him to hear the works in their entirety. It must indeed have been "elektrisierend" for the young man to piece together his impressions of music using the complex Wagnerian librettos, struggling amid the chaos of contemporary musical criticism. With Löwenthal, he worked at recreating for himself what he sensed was the "artwork of the future."58 Chamberlain rented an organ by the hour in Gstlegwyler, a

57 It is now difficult to understand the appeal the librettos had especially for French intellectuals; Wagner's premise of unifyirg myth and music simply caught on with nineteenth century culture and promised a great deal which technically could not be realized, it is often pointed out, until nearly our own day. The influence of Wagnerian style is enormous, detalled in, for example, Elliott Zuckerman, The First Hundred Years of Wagner's Tristan (New York: Columbia University Press, 1964) and Jacques Barzun, Darwin, Marx, Wagner: Critique of a Heritage (New York: Anchor Books, 1941; reprinted 1958) and bibliography below.

58 Iebenswege, pp. 196-197. 
town near Interlaken, and experimented with Wagner's motifs. For example, he remembered later having endlessly played the "Sword-Motif." He was to continue practicing music in Cannes, in Italy, and later in Ceneva, and believed-as with so many of his other interests in science and religion--that had his childhood allowed him an early start in instruction, surely he could have become an accomplished musician. 59

Having built up his expectations about the Wagnerian works, it is understandable that Chamberlain might have been disappointed with his first viewing of a work produced on the stage, and so it was. In 1878, in Munich, he saw a poorly executed Tannhäuser. Awkward staging, bad acoustics, and uninspired directing characterized many of the early Wagner productions, and contributed much to the hostile reception Wagner experienced. The next year, when Chamberlain went to an inferior performance of Lohengrin, he actually walked out in the middle of the second act. But, his faith in Wagner was redeemed when, a few weeks later, he and Anna attended a Munich performance of the Ring.

After his father's death earlier in 1878, Chamberlain and Anna had married, and now possessed financial independence sufficient to pursue their artistic interests. After enjoying the Ring performance, in November, 1878, Chamberlain joined the Patronatsverein, which had been founded to finance the future Festspiele at Bayreuth. Chamberlain had, however, at this time only the barest notion of what the social and political implications of the Bayreuth Idea actually were. His enthusiasm was enormous, comparable to Nietzsche's discovery of Wagner.

59 Ibid., p. 222. 
As pointed out by Field, however, whereas Nietzsche was to become disillusioned with the first Bayreuth Ring Festspiel, Chamberlain would with increasing proximity to the "temple" of Wahnfried, become more devoted to the Meister; it was only with portions of the dogmatism of the inner Kreis that Chamberlain was to experience doubt at all.60

Now a member of the Patronatsverein, he received the Bayreuther Blätter, which had begun disseminating the Meister's views from 1877 . However, Chamberlain had definite ideas himself about interpreting Wagner, and during the winter of 1878-1879 when he and Anna moved to Florence, he wrote an article he hoped the Bayreuther. Blätter would publish. This essay in fact is an ironic sort of correspondence to find Chamberlain later publishing since it criticized the very ideology he later adopted. In his memoirs he discussed it and printed excerpts from it which only make sense when compared to his role as a Bayreuth publicist after 1886. In this early article he challenged the tendency of the Bayreuth publicists to insist upon particular interpretations in not simply the artistic, but the social and political realms as well. He advanced the sort of criticism which he himself was to face later working for Wahnfried. Evidently it was with surprise Chamberlain found how far he was from the increasingly militant Bayreuth Idea. Ey 1889 his aesthetic, political and social views had changed enormous ly from those of this 1879 essay:

It is a completely false and most reprehensible procedure to extract a specific philosophical teaching from art-work. In considering an artist's creations we need not enter into his personal views. His works breathe a higher spirit, and there is scarcely a more unfortunate and harmful notion to the cause

60 "Houston Stewart Chamberlain: Prophet of Bayreuth," p. 75. 
the (Wagner) Verein represents than the idea of exposing philosophical views of the Master by means of his works. Outside pure enjoyment of beauty the effect of an Art-work is and can only be an aesthetic and - indirectly - an ethical one . . . . . . . . . . . . . . . . . . . . . . Art affects us directly, and its advantage morally is that it, to some extent, elevates man above himself and purifies his spirit without his having to retrace the many stages of ratiocination. For an intelligent man the consequences will naturally be that he is induced to think a lot. But Art a product of genius which reflects general and absolute Beauty and Truth - can never act as the vehicle for a par ticular and specific teaching. 61

Particularly Chamberlain inveighed against Wolzogen's formulation of the regeneration produced by mixing Germanic and Christian values. As Field notes, this 1879 heresy by the youthful Chamberlain vitiates the very essence of the Bayreuth intermingling of art, religion and Deutschtum. 62 Taking the position that Kant had delegated separates existences to the realms of art (or noumena), and the external world (or phenomena), Chamberlain here attacked the infusion of Schopenhauer that Wagner and his publicists were using in constructing German redemption. Such works as Schopenhauer's The World as Will and Representation (1819) were in vogue, and believed by Chamberlain to vitiate, not support, the Konigsberg philosopher. All his life Chamberlain was to remain critical of such post-Kantian alterations, and rejected any notion of pessimism emanating from such writers. But Chamberlain's own synthesis--in his view-was beyond the realm of such manipulation. 63

${ }^{61}$ Chamberlain Nachlass quoted in "Houston Stewart Chamberlain: Prophet of Bayreuth, "p. 78 .

62"Houston Stewart Chamberlain: Prophet of Bayreuth," p. 79. ${ }^{63}$ Ibid., pp. 80-81. 
Chamberlain was amazed at the vehemence of the Bayreuthians: in the next issue of the Bayreuther Blatter not only did Wolzogen fail to print Chamberlain's letter, but he printed a passing reference to it, damning it as exactly the sort of misinformed opinion against which the defenders of Wagner had to contend. Wolzogen stated that it proved that only Germans could truly understand the totality of Wagner's art.64 This event temporarily restrained Chamberlain's enthusiasm for Bayreuth, but, as he maintained later, he never was untrue to Wagner; instead, he plunged himself into scientific work in Florence, and later in Geneva. It was not until 1882, when he attended the Bayreuth opening of Parsifal, that he became active in support of the Meister.

64 Iebenswege, p. 218. 


\section{CHAPTER V}

\section{CHAMBERLAIN'S TRANSFORVATION}

\section{9-1884: FIORENCE AND GENEVA}

Now, at age 23, financially independent and without the encumbrance of his father's directions, the choice of Florence as a residence was intended to combine Chamberlain's medical needs with his artistic and scientific interests. He desired to begin biological studies, but found himself instead attracted to the great architectural and cultural offerings of the Italian city. Like many nineteenth century aesthetes, he found himself fascinated with the greatness of the classical tradition, the vitality of Mediterranean spectacle, and he read the greatness of the Renaissance through the views of Ruskin and the Pre-Raphaelites. Perhaps this "feast" of culture as well assauged the Chamberlain so recently castigated by the Bayreuth publicists; certainly the impact of Giotto, Donatello and Fra Angelico took Chamberlain by "Rausch." Previously unaware of the entire period of the Renaissance, in 1879 his days wert: to be devoted to touring the plazas and galleries of the great city. ${ }^{1}$ Chamberlain was also busy making new acquaintances and enjoying, the musical offerings of the city. He knew musicians in the Florence orchestra, the Germans Karl Hildebrand and the art historian

\footnotetext{
${ }^{1}$ Lebenswege, pp. 223-224.
} 
Bayersdorfer. He avidly read Burckhardt. ${ }^{2}$ Thus his involvement was great in things Florentine, but by spring 1879, he began to suffer misgivings about his achievements in the splendid city. He felt he needed the discipline of the "Northern Iife," the restraint of "Duty," etc., so lacking in the sunny south of Europe. The fear which took hold of him simply was that he might be becoming another dilletante who would never master any particular skill. 3 Because of the proximity of Switzerland, and because of the prestige of the University of Geneva, Chamberlain decided to move to that city and begin to apply himself seriously to science. He found the semester had already begun, and his own preparation uneven; he therefore plunged into studies to qualify for admission to the University. By the fall of 1879 he had passed these examinations, and began a demanding series of studies at the University. He studied biology, botany, and attended some geography, astronomy, and anatomy classes. He criticised the narrow-mindedness of many of his fellow students who did not take such forays into other disciplines, and prided himself on his catholicity during this period. Instead of spreading out his Bacclaurate examinations over several terms, Chamberlain took them al.1 in the fall of 1881 , and earned first

$$
\text { Ibid., p. } 85 \text {. }
$$

3 This was one of several such occasions Chamberlain later described in his books. He appeared to have had, or to have later belleved he had, the moment of decision presented quite dramatically: he was in a nearly religious trance, struck with the revealed truth of his destiny. The type of certainty imparted by this sort of conversion fitted well with his emerging Lebensphilosophie of racism, intuition and determinism. It may be likened to similar occasions when, for example, men like Hitler were "convinced" of the rightness of their actions by the emotional intensity of their decisions: the individual appeared as the result, not the initiator, of the choice made. 
place in the University examinations. Assured by Dr. Graebe that on the basis of his performance he could expect to earn his doctorate in one additional year of study, Chamberlain chose to continue his studies. However, not happy with Graebe's choice of a thesis topic, he soon became ill. The exertion of rigorous studying had again exhausted Chamberlain, and under doctor's orders he postponed his doctoral research.

Through further reading and reflecting about this situation, Chamberlain came to favor a different approach than the biochemistry pursued by Graebe. This new project was one which Chamberlain undertook independently, setting up a laboratory in his Geneva apartment. He installed an array of steam fittings and gauges to test sap responses of plants under different pressure conditions. Toward this end he kept a rigorous schedule of observations on his project, which allowed him little rest. 4

The basis of his new idea was derived from reading Goethe and his own long-fermenting synthesis of the "eye" and intuition. While previous research on the subject of sap movement, plant respiration and root pressure had indicated some relationship did exist, Chamberlain found himself bogged down in a mass of detail which he wais unable to interpret. The anticipated short and successful conclusion to his studies thus became less probable, and later he was to write that the pressure of this research was responsible for his breakdowr in $1884 .^{5}$ He sought a variety of pastimes during this period; in

4 Lebenswege, pp.102-103.

${ }^{5}$ Chamberlain was to claim the real cause of his breakdown in 1304 
particular he resumed studying the violincello and attended concerts by the Jew Anton Rubenstein. ${ }^{6}$ In September, 1882, he and Anna moved from their small apartment in Geneva to a rambling villa on the outskirts of the city, and he began studying the piano and reading Nietzsche, His wide-ranging interests in the literature of England, France and Germany still led him to espouse a vague liberalism, not yet metamorphosed with residence in Germany. ${ }^{7}$

While Chamberlain was ostensibly recuperating from overwork these were happy times for the couple. He kept abreast of international everts, and his private correspondence continued to reflect a Gladstonian liberalism. He was, however, willing to use the thencommon deprecations of Jews, often refering to Capitalism, for example, as synonymous with Judaism, and he particularly resented what he thought was Disraeli's "coarsening" influence upon both foreign and domestic English politics, He viewed such actions as the filibustering efforts of Parliamentary groups as corrosive indications of

was his revolutionary attempt to link Goethe and Kant in his researches. However, in Geneva he sought a mechanical solution to the problem, not the vitalism he later considered, after 1885, in Dresden. Field points. out the other pursuits of these days contributed at, least as much tn his breakdown. and these difficulties (discussed below) were kept by Chamberlain strictly away from the public's view. See Lebenswege, p.107 and "Houston Stewart Chamberlain: Prophet of Bayreuth," pp. 44 and 59-70.

${ }^{6}$ Rubenstein (1847-1884) was to suffer the contradiction of Wagnerian Ideology and anti-Semitism. He resolved this only with his own suicide. In a manner which anticipated many Nazi-era convoluted reasonings, Chamberlain wrote that Rubenstein was not really a Jew at all; rather he was "a mixture of Mongol and Aryan." Lebenswege, pp. 228-230.

. 7"Houston Stewart Chamberlain: Prophet of Bayreuth," pf. 45-46. 
degeneration, and saw English policy in South Africa as oppressive. Also at Geneva, Chamberlain was aware of radical and anarchist groups and he shared vague affinities with them - without, however, supporting their specific measures, Similar to many nineteenth century aesthetes, Chamberlain was particularly receptive to Proudhonist thought and its variants. ${ }^{8}$ While he remained aristocratic in temperament, in his cultural criticism he insisted on stressing the values of personality, independence and Gemeinschaft.

In 1882 the couple was able to visit Bayreuth for the premier performances of Parsifal. The experience was important, embodying much more than simply an artistic experience. Now Chamberlain sampled the milieu of Bayreuth. The couple journeyed to Bayreuth by train in company with "real Wagnerians," an experience demonstrating to Chamberlain the impressive social and intellectual credentials of that group. He saw them as representatives of the continent's best suciety. Enchanted with the religiosity of Bayreuth, with the notion of the Grail community, and with the redemption theme, Chamberlain found himself once again eager to aid the "artwork of the future." After seeing Parsifal six times, ${ }^{10}$ he wrote to Harriet, "I fear you will think us very Wagner-mad when we come back. My position in regard to Wagnerjsm, my appreciation of the fundamental idea of the Music Drama have greatly

${ }^{8}$ Ibid., pp. $46-59$.

9 Lebenswege, pp. 234-235.

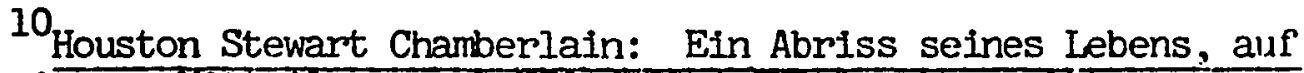
Grund eigener Mittellungen, p. 59. 
changed in the course of the last week. "11 Chamberlain saw the Meister himself several times during the Patronatsverein ceremonies, an experience he compared to viewing that other world-historical figure-Wilhelm I-at Bad Ems in 1870.12

Early in 1883, Wagner died, and his supporters had grave reservations about the very survival of the dream of Bayreuth. Cosima failed to show leadership amid the quarreling Wagnerites, and the inner Kreis sought to tighten-up the bonds of orthodoxy. Feuds resulted and the simultaneous challenge and responsibility of helping the cause drew Chamberlain to offer himself to the cause. He attended frequent meetings of the Patronatsverein in 1883, and wrote Harriet that he now considered himself among "the small cohort of real Wagnerians. "13 $\mathrm{In}$ 1884 he was permitted an audience with Cosima's oldest daughter at Wahnfried, and because of his new business connections in Paris, was chosen to represent the Allgemeine Richard Wagner-Verein in that city. ${ }^{1.4}$ In 1883 Chamberlain took up residence in Paris and dabbled in the financial world. This phase of his life was shielded from later publi.c view, and has only been exhumed with Field's Bayreuth researches. While Chamberlain was to later excoriate the soiled hands of financiers, and while at the time he and Anna had no pressing financial needs, evidently in 1883 he felt the frustration again of the dilettant's lifte.

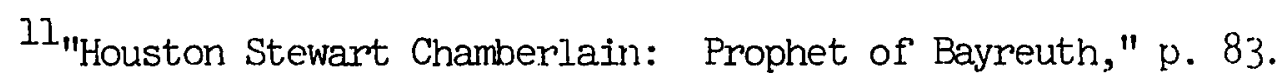
12 Lebenswege, pp. 242-243.

13"Houston Stewart Chamberlain: Prophet of Bayreuth," pp. 84-85. ${ }^{14}$ Houston Stewart Chamberlain: Ein Abriss seines Lebens, auf Grund eigener Mitteilungen, p. 62. 
He had been unsuccessful in achieving his doctorate, and was occupied only with the defense of Wagnerism. In view of the decade's financial instability, it is possible he saw the interest on his investments declining; perhaps he disliked having to spend his principal to maintain his life-style. Chamberlain appears to have thus attempted to reap large profits quickly in the Paris ventures, which would have allowed him then to return to the academic field. However, his partnership failed, and a subsequent attempt on his own likewise went under. For reasons not accounted for in the available sources, the enterprise then absorbed not only his own capital, but also that which he had borrowed from relatives in England, 15

Distraught with the turn of events, Chamberlain fell ill, and in late 1884 Anna was forced to close up his business affairs in Paris. Interested in recuperating in a less expensive, yet artistically stimulating atmosphere, the couple selected Dresden. Field noted that now Chamberlain was dependent upon relatives, and during the long recovery and refurbishing of his world-views he lost the habit of financial independence. Though his future publishing career would be increasingly remunerative, from 1884 Chamberlain never ceased Living off the largess of both his relatives and several wealthy admirers. ${ }^{16}$

15"Houston Stewart Chamberlain: Prophet of Bayreuth," pp. 59-6\%. ${ }^{16}$ Ibid., pp. 67-70. 


\section{5-1889: DRESDEN}

Houston and Anna Chamberlain arrived in Dresden late in 1885. From this time on Chamberlain was to live in German lands, with very few visits to relatives in England. His recovery from the "Nervenleiden" was painful and slow, and he was "tormented by thoughts of suicide."17 Doctors affirmed that his condition would never permit concentrated work again. Chamberlain had the greatest difficulty in even reading for periods longer than a few minutes through 1886; but with Anna's attention and careful selection of activities, his critical faculties returned, and allowed him to resume his wide-ranging, intellectual pursuits. A certain Dr. Kraepelin in Dresden approved of Chamberlain's activities, cautioning he should, in particular, abandon scientific research. ${ }^{18}$ The couple travelled occasionally to Norway, Berlin, Munich and Bayreuth. In these Dresden years Chamberlain gained an acquaintance with the performing arts which had been previously limited. He later stated without modesty that in abstract reasoning he found less discomfort than in the rigors of empirical research. 19 His reading habits at first turned to the favorites of his youth, and Chamberlain related how he "rebuilt" his perceptions anew in this beautiful city. He reread many of the Scott novels and various

${ }^{17}$ Gerd-Klaus Kaltenbruner, "Houston Stewart Chamberlain--the Most Germanic of Germans," the Wiener Library Bulletin (Winter 1967/ 1968): p.8.

$$
18
$$
Lebenswege, p.111. ${ }^{19}$ Ibid., p.111. 
adventure stories. But soon he began in earnest to study authors who provided him with material he would draw upon for the rest of his creative life: Stendahl, Baudelaire, Taine, Renan, Victor Hugo, Theophile Gautier, Vacquerie, and Zola together with more of Plato, Kant, Leibniz, Lichtenberg, Gibbon and Sterne. ${ }^{20}$ He justly termed these authors in the best tradition for contemporary cosmopolitan Europeans. But he also was increasingly interested in more exotic offerings, enjoying for instance the Upanishads. In his reading he traced the development of philosophy from Plato to Kant, and begarn to study seriously the pantheon of Wagnerian works and sources.

While at first Chamberlain's nervous exhaustion ${ }^{21}$ provided the domestic ingredients for a closeness between Houston and Anna similar to their pre-Geneva days, as Chamberlain became drawn into the orbit of Wagnerism, Anna was increasingly left behind. She had problems of her own, was nervous and sickly, and was 10 years older than Houston. Friends of the couple were usually tied to the Wagner influence; for example, the painter Ernest Kietz (1816-1892) and his brother the photographer Gustav Kietz (1826-1908) were frequent company for the Chamberlains. These brothers were clder members of the Wagner Kreis,

${ }^{20}$ Ibid., pp. 315-318.

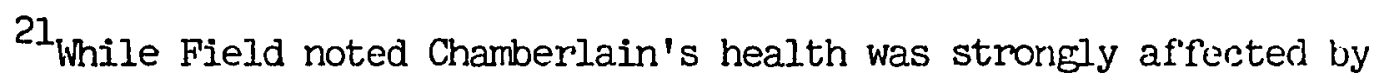
nervous factors, his doctors believed he ultimately died of a form of Parkinson's disease, and one wititer believed he was afflicted with multiple sclerosis: Hans Ziegler, Adolf Hitler: aus dem Erleben dargestellt (G8ttingen, 1965), quoted in "Houston Stewart Chamberlain: Frophet of Bayreuth," fn. pp. 87-88. A more bizarre and also unsubstantiated theory was that held by Winifred Wagner's daughter, Friedelind. She believed that Chamberlain's debilitating illness wat: really syphilis. "The Wagnerian Ethos in German History," p. 328. 
and it was Gustav who introduced Houston to Cosima Wagner in 1888. The Chamberlains attended the first Bayreuth performances of Tristan und Isolde and Die Meistersinger, and corresponded with the inner Kreis. In Dresden Chamberlain witnessed the workings of the Gerran Second Empire. He saw the corrosive effects of Bismarck's policies of "negative integration," especially the failure of the anti-Socialist Laws. The late-century mood of many Germans--and Europeans generally-of unease with materialism and the liberal ideology of Progress found partial release in anti-Semitism and anti-Capitalism. Particularly in the German-speaking lands bordering on the Slavic East and South-East, Germanic, Slavic and anti-Semitic tensions rose and were significant long before they were similar problems in the heart of Germany. ${ }^{22}$ Also, the provincialism of the Saxon capital reinforced doubts about the wisdom of the Prussian political leadership in Germany. 23

Because of his facility in French and his contacts in the French capital, Chamberlain became an important French language publicist for Bayreuth. He worked with such writers as Eduard Dujardin and Theodo de Wyzewa in supporting the embattled Revue Wagnèrienne. Field described how Chamberlain's difficult task of interpreting the Bayreuth Irlea to France broadened his own understanding of contemporary issues as well

${ }^{22}$ Erik R. von Kuehnelt-Leddihn, "The Bohemian Background of German National Socialism: The D. A. P., D. N. S. A. P., and N. S. D. A. P.," Journal of the History of Ideas, IX $n r$. I (January, 19/18), pp. 339-371. Kuehnelt-Leddihn tended to attribute Nazism and "collectivian" in general to Protestantism. However, he cogently observed that in many ways Hitler's collectivism was the culmination of post-1789 Democratic tendencies in Europe.

23"Houston Stewart Chamberlain: Prophet of Bayreuth," pp. 89-3n. 
as his theories about Wagner. The Revue Wagnèrienne from 1885 adviocated the reorganization of modern aesthetics and the disparate strands of contemporary literature, and Chamberlain attempted to mediate between the avant garde French Wagnerites and the more traditional financial supporters of the Revue Wagnèrienne. 24 With the last publication of the journal in 1887 amid battles of ideology unknown in German Wagnerian circles, Chamberlain sensibly supported the temporizing faction, which with Dujardin rallied around the Revue Independente. 25

While writing for the brief-lived but influential Revue Wagnèrienne, Chamberlain interpreted Wagner for the French Symbolists as a prose and poetic genius who utilized music to invoke psychological resonance. He appeared, then, to be still quite close to his earlier, 1879, interpretation. Wyzewa, however, led a mystical wing concerned increasingly with "mysteries." At the other extreme, Wolzogen with the Bayreuther Blätter insisted on Wagner's absorption of Schopenhauerean redemption. Thus, at this period, Chamberlain still retained a Yartilian respect for autonomy. For example, the disputes over Parsifal were succinctly depreciated by Chamberlain in those years: "There is no more Christianity in Parsifal than there is paganism in the Ring and . Tristan. "26

24 Ibid, , pp. 91-94.

25].bid., pp. 95-99.

26Houston Stewart Chamberlain, "Notes sur. Parsifal," Revue Wagnèrienne, August, 1886, quoted in "Houston Stewart Chamberlain: Prophet of Bayreuth," pp. 100-101. 
Real success, however, came for Chamberlain's ambitions in Germany with his first German-language article: a discussion of the relationship of speech and music in Tristan in the Allgemeine MusikZeitung of Berlin. 27 Also, Chamberlain wrote an essay pleasing, to Cosima Wagner on the relationship of her father Franz Liszt and her late husband Richard Wagner, Since the Bayreuth publicist Heinrich von Stein had died suddenly the previous year, Cosima was seeking new supporters; recognition of Chamberlain in the German press paved the way for the two enthusiasts' meeting at the house of Gustav Kietz in Dresden in 1888 . Chamberlain began the conversation by saluting Cosina with his proclamation he was "no Wagnerian, rather a Bayreuthian. "28 Cosima wrote her daughter Eva (from 1908 Chamberlain's second wife) that she had been introduced to a true and symoathetic man, "an aristocrat through and through, in the best sense of the word!" 28 These words set the tone of the Chamberlain-Cosima relationship, which always retained its formality, even when disagreements were very evident between the two difficult personalities. This meant that their published correspondence deceptively portrayed blissful harmony: Field and Schller, however, have uncovered the underlying problems in the nearly mother-son relationship.

27 Houston Stewart Chamberlain to Cosima Wagner, letter of October 12, 1888, in Cosima Wagner and Houston Stewart Chamberlain, Cosima Wagner und Houston Stewart Chamberlain im Briefwechsel 18881908 (Leipzig: Philipp Reclam, 1934), p. 25.

$$
28
$$
Briefwechsel introduction. p. 7. ${ }^{29}$ Ibid., p. 8. 
The importance, then, of the year 1888, symbolized by the meeting of Houston and Cosima, was great as well for Chamberlain's emerging Weltanschauung. Chamberlain began to make the swing toward ideological Wagnerism. Through studying the Wagnerite writings of Stein, Wolzogen, Glassnap and the early Nietzsche, as well as the mythologies used by the Meister, and living in the rococo German city, confronting "alien" eastern peoples, Chamberlain became more an advocate of that peculiar substance at best described as German Idealism and at 1ts worst naned Nazism. ${ }^{30}$ Later Chamberlain recalled a growing sense of continuity in the Dresden years, a unity of religion, aesthetics, literature, art and history. He wished he could see the world through Plato's eyes; he understood this as being the restructuring of sense. impressions, the discarding of any merely "pedantic" method. The result would be perception through a God-given medium, the transformation of consciousness as sought in Brahman teachings. 31 This search for "das

$30 \mathrm{~A}$ useful discussion of this wide spectrum of political/aesthetic hues appears in an exchange between two writers in the Journal of the History of Ideas, V nr. 2 (January, 1944): 191-210, between Arthur O. Lovejoy and Leo Spitzer. The discussion centers about the validity of such terms as Romanticism when historical differences intervene and is central to the historiography of figures such as Houston Stewart Chamberlain. Spitzer stated that it was only the corruption of the romantic notions of Ganzheit, Streben and Eigentlumlichkeit which made: possible a linking of Nazis with Romantics. Educated Germans did rot support the Nazis, who (in Thomas Mann's words) were "truants from school". This statement, however, needs the qualification that antiSemitism was endemic among Germans before the First World War, not simply among fringe and lower social groups. Geoffrey G. Field, "Antisemitism and WeItpolitik," Yearbook XVII: Publications of the Len Baeck Inst,itute (London: Secker \& Warburg, 1973), pp. 65-91.

${ }^{31}$ Lebenswege, p. 338. 
$\underline{\text { elgentliche Buch" }}{ }^{32}$ would proceed beyond mere Schopenhauerean popularizations, back to the understanding of Kant. illuminated by Chamberlain's own formulation of Christianity. Thus, for Chamberlain, the "core" of mysticism resided in the search for this elusive ideal, the incompletely realized quest only indicated by "ein Frllingsprossen des Geistes". 33 The German striving for die blaue Blume thus was updated for service to a contemporary ideology: the Bayreuth Idea.

Previous to his meeting with Cosima, Chamberlain had espoused a generally liberal and tolerant set of views. But, in Dresden, he moved from his Kantian respect for non-ideological art to something along the lines of Wagnerian redemption through art. Studying Renan, Schleiermacher, Novalis, Friedrich Schlegel, and E. T. A. Hoffman, Chamberlain considered more the collective or v8lkisch natures which he believed underlay reality. The slow conversion of his Liberalism into a reactionary amalgam of anti-Jewish, anti-Capitalist mysticism was indicated by his increasing perception of Wagner's art as not simply aesthetically potent, but in fact redemptive. 34

Particularly, Chamberlain saw Schiller's Ietters on the Aesthetic Education of Man leading from his former more strict Kantian separation of artistic and worldly realms to a new-found unity. This work, popular among many as well as Bayreuth enthusiasts, stressed aesthetic: humanism as the means modern man might use to regain the harmony ristzed

32 Ibid., p. 282.

33 Ibid., p. 282.

34 "Houston Stewart Chamberlain: Prophet of Bayreuth," pp. 104105. 
by the classical Greeks. Increasingly Chamberlain saw the social issues of late Wilhelmine Germany filtered through the Wagnerian notions of Idealism and Deutschtum; by 1889 his acceptance of the Ring as allegorical truth, of Parsifal as religious devotion, and of Die Meistersinger as paen to nationalism was confirmed. 35

He stated that in Dresden he laid the foundations for his creative works of the next 20 years. ${ }^{36}$ He thus participated in the ideal of Bildung so popular in nineteenth century Germany. Chamberlain did, however, assiduously apply himself to this task, reading French and English as well as German dramatists, lyricists and mythologies. Especially he studied the Greek heritage dear to Germans ${ }^{37}$ and found affinities with that earlier admirer of things German, Thomas Carlyle. He seriously studied Kant, then Goethe and (in line with his growing society with the Wahnfried Kreis) re-evaluated Schopenhauer. He continued to decry the "factitious and exaggerated enthusiasm for Schopenhauer" extant in the nineteenth century. ${ }^{38}$ Chamberlain's

${ }^{35}$ Ibid., pp. 105-107.

36 Lebenswege, p. 342.

37 The obsession of Germans since the Sturm und Drang with the Greece of Winckelmann, typified by the lives of HB̈lderlin, Nietzsche and Stefan George, was traced by E. M. Butler, The Tyranny of Greece. Over Germany (1926; reprinted ed., New York: Howard Fertig, 1968), and is illuminating since the Bayreuth Kreis fell heir to this tradition.

${ }^{38}$ Chamberlain was enthusiastic when he discovered this statement in Friedrich Albert Lange, History of Materialism, trans. Ernest Chester Thomas (1865; reprint ed., Iondon: Routledge \& Kegan Paul I.ted, 1950), p. 154 as quoted in "Houston Stewart Chamberlain: Prophet of" Bayreuth," p. 109. The history of the movement of which Lange's bork was a part was traced in Thomas Edmund Willey, "Back to Kant: The Revival of Kantian Idealism in Germany, 1870-1914" (Ph.D. disscrtaticr, Yale University, 1965). 
discomfort with post-Kantian philosophy was itself the subject of a monograph. 39 He wrote to Cosima how Schopenhauer's preoccupation with affect and the analysis of pleasure violated rational sensibilities. Similarly, Schopenhauer for Chamberlain was at once dogmatic and, mystical; however, Chamberlain did credit Schopenhauer in what he called the realm of the purely transcendental. ${ }^{40}$ But the composition of this "plastic" realm became very malleable in Chamberlain's harids. 41

Studying Schopenhauer, Chamberlain then became interested in the eastern mystics, and read both popular and scholarly works. Remaining close to this contemporary Orientkomplex, ${ }^{42}$ later in Vienna and in Bayreuth, Chamberlain enjoyed association with the oriental scholars Paul Deussen and Leopold von Schroeder. In his reading he was wideranging and rapid; the combination provided the numerous citations which studed his publications and his correspondence. It was not, however, generally a serious reading, habit in which the reader attempts to comprehend an author's ideas. Chamberlain browsed through an averafee

39 Egon B. Curtiner, Chamberlain gegen Schopenhauer: Eine Urtersuchung der von Houston Stewart Chamberlain in seinem 'Immanuel Kint' an Schopenhauer gellbten Kritik (Dulsseldorf: Schmitz \& Olbertz, 1910). 55.

${ }^{40}$ Chamberlain to Cosima, January 22, 1889, Briefwechsel, pp. $48-$

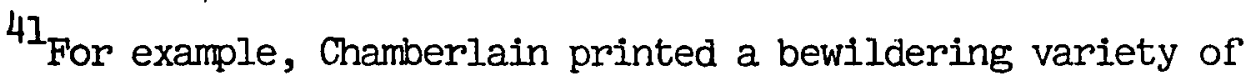
graphs intended to convey his typology based upon intuited relationships in his Immanuel Kant: A Study And A Comparison With Goethe, Leonardo Da Vinci, Bruno, Plato and Descartes, trans. by Lord Redesdale, 2 vols. Tunich: F. Bruckmann, 1904; English edition London: John Lane The Bodley Head, MCMXIV) vol. I, pp. 351-352 and 359; vol. II, pp. 111, 177 and 320-323.

42 This term is used in "Houston Stewart Chamberlain: Prophet of Bayreuth," p. 110. 
of twelve books a day, ${ }^{43}$ A close acquaintance, Hermann Keyserling, related that Chamberlain was characteristically perched on a ladder in his library, rifling through volumes in search of citations to support his views. 44 In Burckhardt's words, Chamberlain might be termed one of modern society's terrible simplificateurs, 45

In this shallow and incomplete pattern of research, Chamberlain was, however, a nearly perfect example of the "intellectual" compromise accluimed by the late-century bourgeoisie. As did the increasingly nervous German late-century middle class, Chamberlain himself found in Wagner's synthesis of art and politics a sort of "rainbow bridge" over which Idealism could make sense of Bismarck's "blood and Iron" reality. The racial fears and assorted fetishes-as, for example, vegetarianism and anti-vivisectionism--of the Wagnerites were sampled by a fearful Blirger class: postulating trans-political solutions appealed to fears of a rising proletariat, of industrial competition, and of cultural diversity. 46 It is significantly apparent that while such an astute observer of society as Nietzsche could first join the Wagnerite movernent, with its extension, deepening and popularization he would abandon it. . Chamberlain made the reverse intellectual movement. ${ }^{4}$.

${ }^{43}$ Ib1d., p. 323.

44 Hermann Graf Keyserling, Reise Durch Die Zeit (Innsbruck: Verlag Der Palme, 1948) pp. 134-135.

${ }^{45}$ Quoted in "Houston Stewart Chamberlain: Prophet of Bayreuth," p. 253.

46 This complex of attitudes was detailed in Herman Lebovics, Social Conservatism and the Middle Classes in Germany 1914-33 (Princetor:: Princeton University Press, 1969).

47"Houston Stewart Chamberlain: Prophet of Bayreuth," pp. 111-113. 
In Dresden Chamberlain became particularly susceptible to the blandishments of Cosima, to the later Wagner essays (especially those written between 1878 and 1882) and to the issues of the Bayreuther Blytter. Cosima wrote Chamberlain during this period how ironic it was Bayreuth now was dependent upon the very sort of people for whom Wagnerian art was not intended-their contribution, however, allowed the survival of the Festspiele. 48 It was exactly "the viscious and unco.promising tone of Richard Wagner's last essays" which Chamberlain cherished, and most particularly, the programmatic of Parsifal. ${ }^{49}$ But, like Wagner, Chamberlain was unsympathetic to mere parliamentary solutions. "Chamberlain's fears transcended the Jews; his hatred was the expression of broader psychological class and cultural anxieties."50 In this deep level of concern he thus mirrored the fears of the late nineteenth century German bourgeoisie.

\section{FROM 1889: VIENNA}

The Dresden years were to be the last happy ones for Anna Chamberlain. She felt closer to Germany in this city, preferring the:

${ }^{48}$ Cosima to Chamberlain, September 17,1888 , Briefwechsel, p.r.3. It is ironic to find Cosima Wagner, the ex-Catholic Frenchwoman whose father, Franz Liszt, was gravitating increasingly toward "Rome" writing. to the English Chamberlain, speculating about how such a great discovery as that of the New World by Columbus had furthered "the establishment of Catholic Tyranny." Cosima to Chamberlain, October 27, 1888, Briefwechsel, p.35.

49"Houston Stewart Chamberlain; Prophet of Bayreuth," pp. 113-116. 50 Ibid., pp. 113-116. 
sights, customs and friends the couple had here to those of Vienna, where they moved in 1889. 51 In Dresden, the couple's interests in culture could be shared, and they had the leisure to indulge themselves with travel, concerts and discussion. However, by the spring of 1889, Chamberlain had recovered from his breakdown, and again thought of completing his academic work. Perhaps his motives were tiea to financial dependence upon relatives, or perhaps he saw in Vienna a chance to defend the Bayreuth Idea in an environment glittering, with both friendly and hostile talents. ${ }^{52}$ One biographer suggests Chamberlain was depressed in Iresden $;^{53}$ certainly Cosima disliked the "melancholy" city, writing Chamberlain the Dresdeners were entirely "unreinmenschlich". 54 In "magic" Vienna, the beautiful countryside arid the accessibility to Alpine vistas appealed to Chamberlain. Perhaps Chamberlain foresaw there would be not simply Austrian but German social and political problems encountered in the Habsburg Empire. ${ }^{55}$ Whatever

51 Meine Erinnerungen an Houston Stewart Chamberlain, p. 100. ${ }^{52}$ A great number of "Proto-Nazis" lived in Vienna at this time, for example, Georg von Schbnerer and Jorg Lanz (von Liebensfels). Adolf' Hitler was born in the same year Chamberlain moved to Vienna, 1839.

53 Ein Deutscher namens Chamberlain: sein Lebensbild nach seinen elgenen Worten, p. 17.

${ }^{54}$ Cosima to Chamberlain, October 23, 1888, Briefwechsel, p. 30. Perhaps her animus was in part traceable to the events of 1848 in that city in which Richard Wagner took part; as mentioned below, the Kreis took the greatest pains to publicise a moderate view of the Meister.'s "revolutionism" in those mid-century days.

${ }^{55}$ One writer intriguingly noted the atmosphere of Kakania pervading the Habsburg Empire [this term comes from Robert Musil's Marn ohne Eigenschaften (Hamburg: Rowohlt Verlag, 1952] and asks, "Was Vienna merely a friendly refuge for Chamberlain, as he himseif saysi" or did complex emotions bind this (Germanophile to a patchwork land?" Gerd-Klaus Kaltenbrunner, "Houston Stewart Chamberlain--the Most Germutnic 
his reasons, the Vienna years were Chamberlain's most creative years. He later wrote about making this choice, "My instinct has never led me astray. 156

Vienna also offered the renowned biologist-and Jew-Julius Wiesner, with whom Chamberlain hoped he could work to complete his dissertation. Wiesner was an author of accepted texts in biology, a lecturer and later rector of the University of Vienna. Chamberlian began re-evaluating his own Geneva researches and read extensively the scientific writings of Huxley, Darwin and Goethe. He attended classes in philology, theology, physics, astronomy, physiology, electricity, and met a wide number of faculty and students from the University. His published statements indicated that due to his Nervenleiden he could only attend lectures, not work at research. 57 Field, however, has established that Chamberlain began seriously working to complete his researches in one year, became disillusioned, and then resumed the wide reading enjoyed in his Dresden years. Additionally, he became involved with a busy social life. In the course of these activities he relapsed into illness. 58

of Germans," p. 8. This is, I think, still an open question, one which perhaps Fleld has answered, but not yet published, in his "larger study" of Chamberlain. Further intriguing discussion of the Viennese environment is given in Allan Janik and Stephen Toulmin, Wittgenstein's Vienna (New York: Simon And Schuster, 1973), and in William J. McGrath, Dionysian Art and Populist Politics in Austria (New Haven: Yale University Press, 1974).

${ }^{56}$ Lebenswege, p. 113.

${ }^{57}$ Ibid., pp. 114-118.

58 "Houston. Stewart Chamherlain: Prophet of Bayreuth," pp. 122.-123. 
His social obligations were concerned primarily with the Vienna Wagnerites. He was known as "der berthmte Herr von Tschamberlan. "59 They welcomed him to their cause; they helped find him accommodations, and occupied his evenings with meetings; discussion groups, ard gala events. Soon Chamberlain devoted most of his time to promoting the Bayreuth cause. ${ }^{60}$ Among close friends were Kaspar Friedrich Wolff, Leopold von Schroeder, and Hermann Keyserling. ${ }^{61}$ Keyserling had studjed at the University of Berlin, but since he was not accepted there as an academic philosopher, had had to be content with being mereiy a "Schriftsteller höherer Ordnung," although Chamberlain noted that in countries such as France, men like Keyserling would be accorded the status of "philosopher." ${ }^{62}$ With Adolphe Appia and such relative; of Bayreuthians as Custav Kietz' daughter, Else, the Chamberlain household was a small society in itself. ${ }^{63}$ Also, as members of the Vienna tourist society, the Chamberlains frequently made outings in the

${ }^{59}$ Chamberlairı to Cosima, November 7, 1889, Briefwechsel, 1). 129. 60 "Houston Stewart Chamberlain: Prophet of Bayreuth," p. 123. ${ }^{61_{\text {Lebenswege, }}}$ pp. 122-123.

${ }^{62}$ Houston Stewart Chamberlain: Ein Abriss seines Lebens, auf Grund eigener Mitteilungen (Munich: J. F. Lehmann, 1918) p. 80 . This "outsider" criticism by the members of the Kreis was a recurrent theme in the examples of Heinrich von Stein and Chamberlain; "insiders," however, were also welcomed by the Kreis if they supported the orthodox tenets, as in the case of the art historian who married Cosima's daughter, Daniela, Henry Thode (1857-1.920).

63 Meine Erinnerungen an Houston Stewart Chamberlain, p. 103. 
surrounding mountains. They journeyed twice far into Bosnia-Herzegovina, and regularly attended the Bayreuth Festspiele. ${ }^{64}$

In Vienna Chamberlain witnessed the conversion of Liberal political dominance to mass political rule by Lueger's Christian Social party. Under the impact of Nationalism, Marxism, and Social Catholicism, the older idealized notion of Habsburg rule seemed decisively crushed. While Chamberlain supported the Pan-Germans led by Georg von Sch8nerer, the compromise of the Ausgleich furthered polyglot diversity in the interests of the Empire as a whole rather than a "German" solution. This situation was seen by many such "Germans" as Chamberlain as a defeat for the cherished anti-Jewish and Los von Rom movements. The defeat was a warning to Germany itself: Chamberlain's work thus in Viennese Wagnerian and German organizations reflected his desire to aid a German regeneration in both Austria and Germany. While he was sympathetic toward v8lkisch values ${ }^{65}$ and increasingly was alienated by English

64 After his journeys into these contested areas, Chamberlain was interviewed by the Austrian Finance Minister, von Kallay. Chamberlain was therefore thought to be a government agent; it is indicative of his; affection for England, however, at this time, that he denied these charges. He stated he "would under no circumstances yield up his English citizenship to seek a position in the Austrian government." Chamberlain to Cosima, March 8, 1891, Briefwechsel, p. 211. Chamberlain greatily admired the rustic peasant life observable in the newly-annexed territories. He retained a naive conception of peasant conditions common to romantics and v8lkisch thinkers. He contrasted bucolic delights to "civilized" urbanity. The American farmers, for example, for him were simply "locomotive drivers" fast becoming-like their western European counterparts-mere "factory workers." He saw the Bosnia-Herzegovina peasantry as "die glllicklichste Volk der ganzen Erde." Chamberlain letter to Herr Alichei, November 5, 1895, in Houston Stewart Chamberlain Briefe 1882-1925 und Briefwechsel mit Kaiser Wilhelm I], vols. (Munich: Bruckmann, 1927), vol. I, pp. 32-22.

${ }^{65}$ Chamberlain wrote, for example, a romantic short story about the peasantry, "Der Weinbauer," in Drei silhnendichtungen (Munich: Bruckmann, 1902) and became interested in Henry Goerge's "single tax" 
forelon policy, he found himself most of all concerned with such internal threats to Deutschtum as he dafly saw revealed on the streets of Vienna. The influx of eastern. Jews in the late century rankled his sensibilities; the danger of Misching with every sort of "Inferior" race appeared to him a danger to Germany itself. 66

Chamberlain's efforts between 1890 and 1896 resulted in articles published in Vienna newspapers and magazines. He spoke before the philosophical faculty at Vienna University about Wagner's philosophy, and before various student and nationalist groups. 67 The 1890's in Vienna saw a great infatuation with Wagner, and this "Wagner sickness" was significant for Chamberlain's own developing Weltanschauung. 68 But the animosity of men such as Chamberlain continued unabated at the often-remarked disproportionate representation of Jews in the city's cultural life. A partial list of Jew: includes Arthur Schnitzler, Gustav Mahler, Henry Frledjung, Sigmund Freud and Arnold Schönberg. 69

idea as it was promoted in Germany, discussed in Chapter VII, below. George L. Mosse, The Crisis of German Ideology: Intellectual Origins of the Third Reich (New York: Grosset \& Dunlap, 1964), p. 109.

66 On one occaston in 1897, Chamberlain actually joined student demonstrators against the Badeni ordinance of that year equalizing the German and Czech languages in Bohemia; his dislike of Slavs was so great he refulsed to read Dostoevsky. "Houston Stewart Chamberlain: Prophet of Bayreuth," p. 202.

67 Meine Erinnerungen an Houston Stewart Chamberlain, p. 110. 68 "Houston Stewart Chamberlain: Prophet of Bayreuth," p. 206. ${ }^{69}$ In addition to the books cited, illuminating articles on the Vienna Zeitgelst have been recently written by Carl Schorske, for example, his "Politics is a New Key: An Austrian Triptych," Journal of Modern History, 39 \#4 (1967): 343-386. 
During the 20 years of his residence in Vienna, Chamberlain grew ever closer to Cosima Wagner, as their published correspondence shows. He complained to her, for instance, about the Akademische Wagner Verein meetings which often degenerated into mere Damenabend; it seemed to him many Viennese merely indulged their passions of eating, drinking, smoking and a little piano-playing rather than attending to serious consideration of the Meister's art. ${ }^{70}$ Chamberlain's own preferences were for the more radical Neuer Wagner Verein which stressed antiSemitism and Pan-Germanism. ${ }^{71}$ To Cosima he confided his two most hatcd human failings: "flippancy and farmiliarity". For example, he decried the manner in which mere casual theatergoers would mention the name of Winckelmann. ${ }^{72}$ Cosima responded, agreeing with Chamberlain about his pet hatreds, noting that "what one often in Germany terms 'Gemlltichke.t. really should be classed as 'influenza."173 It seems the two shared common predilections--most particularly, mutual dislikes--, common goals, and reinforced each other's dilettantism. Often their warm letters discussed Cosima's dreams, and such matters as local crimes in the trown of Bayreuth. They hardly referred to the "outside world," i.e., the 207.

70 Chamberlain to Cosima, Februatry 20, 1891, Briefwechsel, pp. 2.06-

71"Houston Stewart Chamberlain: Prophet of Bayreuth," p. 203. n discussion of the split among these Wagnerian groups is found in Mccroctch, Dionysian Art and Populist Politics in Austria.

${ }^{72}$ In line with the argument Winckelmann's tradition led to Batyroldth, Chamberlain wrote to Cosima of Winckelmann's "Bayreuther Sache," March 3, 1895, Briefwechsel, p. 396.

73 Chamberlain to Cosima, March 3, 1891, Briefwechsel, p. 21.4. 
realm of Europe outside their own personal and artistic lives. One reference about the latest international worker's conference in Paris concerned with stopping militarism, for example, the two summarily rejected. They found it a childish activity which the facts of. history might be expected to ignore. ${ }^{74}$

In 1893 Chamberlain gave a speech to the Wagner Verein at Graz. It was a difficult task, which had to first be cleared through the local police since the intermixture of politics with such meetings was a threat to the unity of the Habsburg Empire. A summary he sent to the police beforehand was accepted, and his speech--his first real opportunity to speak at a public artistic assembly without what he termed a mere social atmosphere-was a great success. He talked for over an hour, and was only moderately damed by what he termed the local "Jewish" press. 75 He continued to speak on behalf of the Wagner cause in Austria, mentioning to Cosima, for example, speeches before the Jugendbund, and to Vienna University's Germania on the subject of regeneration through art. ${ }^{76}$

Particularly interesting during this period was the Conservative electoral triumph, 1892-1893, which brought Court Chaplain Adolf stibcker. (1835-1909) again to national attention in Germany. Influential with the Conservative party leadership, this important figure for the

${ }^{74}$ Cosima to Chamberlain, April 3, 1891, Briefwechsel, p. 215.

75 Exchange of letters between the two: Cosima to Chamberlain, February 8, 1893; Chamberlain to Cosima. February 16, 1893; Chamberlain to Cosima, February 22, 1893, Briefwechsel, pp. 317-319.

${ }^{76}$ Chamberlain to Cosima, May 15, 1896, Briefwechsel, p. 467. 
development of popular anti-Semitism wrote many journal articles. Cosima Wagner was sufficiently interested in him to have dinner with him in Berlin. She was concerned with his politics and with his discussion of the theme, "absolute monarchy yet free people" which was central as well to the ongoing debate about Richard Wagner's 1848 role. Chamberlain and Cosima discussed Stbcker in their correspondence, and agreed that while his concern with parliamentarianism and political unity were tolerable, even partially desirable, the main issue facing Wagnerians was the unity "der Geister". 77 stbcker, Cosima decided, was thus on the right course in some respects, but on the whole had an uninspired, mere "naiven Kohlerglauben" at the root of his streetlevel political style; she preferred the illumination of faith that comes only with Wagnerian art. 78 Chamberlain, however, defended the "naive faith" of. St8cker. As he wrote her, when one had to go "barefooted" among the evil Jews, the contemporary "ruling faithlessness of politics" mandated a measure of naiveté to accomplish anything at all. For Chamberlain, the "naive faith" of a Stbcker merely stood in need of Wagnerian art to become truly effective. 'To convince Cosima of this, and to salvage her opirion of a politician such as Stbcker, he cited Richard Wagner's "Heldentum und Christentum" (1881) that the true foundation of religion must be a Christianity purged of "Churches, Priests, yes the entire superficial appearance of Christianity in history. "79 Thus, did the two writers increasingly f'ind contemporary application for the Bayreuth Idea.

${ }^{77}$ Cosima to Chamberlain, February 19, 1893, Briefwechsel, p. 3.19. 78 Cosima to Clamberlain, March 3, 1893, Briefwechsel, p. 322. ${ }^{79}$ Chamberlain to Cosima, March 23, 1893, Briefwechsel, pp. 324-3?5. 
CHAPTER VI.

CHANBERLAIN'S VOCATION

THE "WRITING DEMON" AND THE PRAEGER AFFAIR

It was with a dramatic f'lourish that in his thirty-seventh year Chamberlain found his true vocation: writing. He related how the "writing demon took possession" of his soul, and how he never afterward was abandoned by this "fever." Fascinated by what he described as the "Architektonisch" aspect of books, and fearing that in his preoccupation with writing he might unknowingyly "cry out aloud" and startle his friends, Chamberlain saw that in order to work he needed to isolate himself from society. ${ }^{1}$ He therefore described in terms suggestive of the intervention of Providence's hand how, on the morning of Januray 19, 1890, he made the momentuous decision. He built himself a high desk at which he could stand to write, and locked the doors to a set of rooms in the couple's apartment. He than began to write down everything that came to him. After many false starts he was satisfied his true vocation was writing. ${ }^{2}$ As Field Commented,

He imagined himself the tool of higher forces and was intoxicated by a sense of mission. This delusion of higher inspiration breathing through his life and work grew stronger in later years, after his literary success, and he tended to read the same supernatural will into the whole story of his life. 3

${ }^{1}$ Lebenswege, $\mathrm{p} .124$.

Ibid., p. 125.

3ouston Stewart Chamberlain: Prophet of Bayreuth," p. 125. 
Similarly to the mystical symmetry of the two thirty-five year halves of Richard Wagner's life, it was thus noted Chamberlain's own life could be so divided. ${ }^{4}$ During the early decade of the $1890^{\text {is }}$ he thus began to write prodigiously for Bayreuth. Having achieved a reputation as a Wagner publicist close to the inner Wahnfried Kreis, Chamberlain was encouraged to plan a major work on Wagner by a Swiss friend, Agenoir Boissier, and Chamberlain's former associates of the Revue Wagnèrienne in Paris. The suggestive planned title was L' Initiation Wagnèrienne, but was dropped when Chamberlain switched to writing the book in German, believing by this time German would be the most suitable language for conveying the Wagnerian values. ${ }^{5}$ The first section was published as Das Drama Richard Wagners in 1892; the rest wais ultimately used in the later large illustrated biography, Richard Wagner, published in $1896 .^{6}$ Between the years 1892 and 1896 the large number of lectures, articles and books made Chamberlain "probably the most important publicist of the Bayreuth cult, defending the 'orthodox' view of Wagner, eulogizing Cosima and urging the redemptive significance of Wagner's art." 7

Themes which reappear throughout Chamberlain's subsequent books are evident in Das Drama Richard Wagners and Richard Wagner. Most,

${ }^{4}$ Houston Stewart Chamberlain; Ein Abriss seires Lebens, auf Grund eigener Mitteilungen; p. 74 .

5 "Houston Stewart Chamberlain; Prophet of Bayreuth," p. 125.

${ }^{6}$ Cosima to Chamberlain, June 13, 1894, Briefwechsel, pp. 378-379.

7 "Houston Stewart Chamberlain: Prophet of Bayreuth," p. 126. 
particularly, he disclaimed any attempt to pedantically record irrelevent details; his purpose was to sketch the outlines of a great personality and its creations. Appreciation of spirit and spirituality would require an empathetic reader as well as a sensitive author. Chamberlain accordingly presented "outlines" of ideas. ${ }^{8}$ The reader was referred to the standard biographies of men of the Kreis for detail. ${ }^{9}$ The same presentation in his later Kant (1905) and Goethe (1912) leave the reader with the impression Chamberlain himself had mastered these other' sources. Particularly important for Chamberlain was his selective use of Goethe's idea of "Contradiction within Unity" to describe the many facets of the Meister's life. ${ }^{10}$

For Chamberlain the significance of Wagner's art was similar to the 1813 hattle of Leipzig, a second Vylkerschlacht. ${ }^{11}$ Artistic and political events were equally significant. Such vexing problems as the Revolution of' 1848 he saw rooted in Wagner's disaffection with his critics and the Irtendant of the Dresden Theater; the revolt itself and the issuance of the warrant for Wagner's arrest were only the occasion--not the causc-of his flight to Switzerland. ${ }^{12}$ With no recognition of the contradiction,

$8_{\text {rhis sensitive biographic style was also followed by Charnderlitin }}$ in two articles written for the Ladies Home Journal on Wagner ((jctob) $r$ and November, 1898) for which Cosima recommended him.

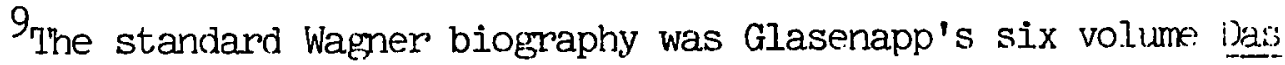
Leben Richard Wagners.

${ }^{10}$ Houston Stewart Chamberlain, Richard Wagner, trans. Airislic: Hight (Minnich: Bruckmann, 1896; English edition, Munich: Bruckmann, 1897), p. 87.

11 Ibid., p. 29.
12 Ibid., p. 51. 
however, a few pages earlier, Chamberlain had admitted Wagner was indeed a 48 "revolutionist," 13 but one merely swept along by developments: "he and his adversaries were temporarily deceived by a semblance." 14 Wagner was the great artist and great man, the "winged Pegasus" and crusader who inspired future generations, 15

The characteristic mark of Wagner's thought is its astounding unity, a unity of things far removed in time, and a gathering together of the heterogeneous under a single point of view. In general, too, this is perhaps the most prominent quality of artistic thought founded on observation and intuition. Of any dialectical process (in the sense of Hegel), every conception evolving necessarily into its opposite, the two then combining to a new synthetical conception, and so on, there is her no trace; it is all organic growth-growth by 'intussection' in which the new elements do not destroy the old ones, but penetrate and expand them. In this way does the oak grow from a seed-germ to the 'Monarch of the forest'; in this way grew Wagner's thought. 16

In explaining Wagner's 1848 Vaterlandsverein speech in which the composer advocated a German colonial empire but domestic rule by a

${ }^{13}$ It has been established Wagner's role in the Dresden uprising was substantial and that perhaps his subsequent concerns with education and art were attempts to further his frustrated political ambitions. Robert Giddings, "Wagner and the Revolutionaries," Music and Letters, 45 \#4 (October 1964): 348-358.

${ }^{14}$ Chamberlain's Richard Wagner, p. 45.

${ }^{15}$ Ibid., p. 92.

16 Ibid., p. 121. One writer noted while Chamberlain blasted Hegel, he appeared to accept Hegel's evolutionary hypothesis of history and the identity of opposites, as evidenced here with Chamberlain's reference to Wagner. Chamberlain was, for example, to claim in his Foundations of the Nineteenth Century (1899) Greek art and Roman law came in the nineteenth century to a synthesis in German culture. "To individuals are sald to be of one blood because of their anti-podal temperaments" was the acidic comment of M. Whitcomb Hess, "Houston Stewart Chamberlain: Prophet of Nazism," Commonweal, May 5, 1939, pp. 37-39. 
federation of kingdoms in which monarchs would rule only as the "first and freest" citizens of a nation of free men. ${ }^{17}$ Chamberlain argued for an apolitical freedom. He linked this with such men as Schiller, Chateaubriand, Carlyle and Proudhon in contradistinction to the "positivist" oriented Lassalle, J. S. Mill, August Comte or Karl Marx. ${ }^{18}$

Chamberlain was particularly delighted that Wagner had forsaken Feuerbach for Schopenhauer for--ultimately--Christ. Feuerbach "not withstanding his desperate endeavors to strike root in healthy experiences . . remained above in the dry air of abstract philisophy, a poor parasite on the withered tree of Hegelianism."19 Later, however, Cosima was to chide Chamberlain for even this acknowledgment of Feuerbach's influence on Richard Wagner. Cosima closely watched and attempted to direct him throughout his publishing career. ${ }^{20}$

Art and religion in Wagrerian terms mutually conditioned one another. Together they promoted the inward resolution of man in the "artwork of the future." Supreme human efforts were required to real ine the purest form of art, and "only in the highest art can the coljective: world consciously apprehend itself; only collective art is highost art." The music drama was "the work and the property of the greatest Germar poets and of the loftiest German musicians: in their name, and at the ir command did Wagner speak and create." ${ }^{2.1}$ It achieved the direct

17 Quoted in Chamberlain's: Richard Wagner, p. 390.

${ }^{18}$ Ibid., pp. 140-142. ${ }^{19}$ Ibid., p. 151.

${ }^{20}$ Cosima to Chamberlain, March 26, 189\%, Srieiwechsel, .1500.

${ }^{21}$ Chamberlain's Richard Wagner, p. 195. 
communication of the truths of Wagner with the "inner man" in the viewer: intellect and emotion were accessible through the means of poetry and music and their amalgamation resulted in a total coordination of man and art. As proof of the power and expressiveness of music, Chamberlain stated we have "the living testimony of our own feelings". 22 Alienation itself was to be overcome in this formulation of art. For those who perhaps had trepidation at the massive structure of the Bayreuth Idea, Chamberlain stated, "the more one penetrates into the real art-work, the more difficult is it not to harm that which is its very essence by the unpliable language of logic." 23 with disarming honesty he further stated that at the heart of the issue was, . . . an overwhelming conviction that a certain music reveals another world to me, that it establishes an immediate contact between my own invisible ego, i.e., that part of man which lies beyond reasoning logic, with the invisible, indefinable, innermost soul of the whole universe, no one can logically prove that I do not feel this; but it is just as impossible for me to prove to him that this music reveals anything to me.24

The grounding of Wagner's art, then, is conterminous with religion itself, an ur-reality which transcends ideology and party in the majesty of aryan man. This most sacred inner reality accessible to humanity through art is the "deeper lying foundation in which all religions have their root, whence they spring forth, to be surrounded with dogma and symbolism only when they enter the visible world." 25

If this prostration before the Wagner cult was not sufficient,

${ }^{22}$ Houston Stewart Chamberlain, The Wagnerian Drama: An Attempt, rik. Inspire A Better Appreciation of Wagner As A Dramatic Poet, tris 1at ti by the Author (Munich: Bruckmann, 1892; English edition, Londor: Jot:1 Lane The Bodley Head, 1915), p. 29.

$$
{ }^{23} \text { Ibid., p. } 110 . \quad{ }^{24} \text { Ibid., pp. 115-176. }{ }^{25} \text { Ibid., F. } 223 .
$$


Field credited Chamberlain's actions in one particular incident as having secured him the dominant role among Wahnfried spokesmen: the Praeger Affair. Ferdinand Praeger had been a German pianist living in London who worked with Wagner during Wagner's 1855 London tour and kept up a subsequent correspondence with him. He had begun writing a book about his relationship with Wagner, and upon his death in 1891 his uncompleted manuscript was reworked and published in London. It was an embarrassment to the orthodox Bayreuthians since it depicted a sybaritic, anti-Semitic Wagner, referred to him as having been a revolutionary in 1848, and described his treatment of his first wile, Minna. During the 7892 Festspiele Chamberlain talked with Ashton Ellis, editor of a multi-volume series in English of Wagner's prose. The two agreed the Praeger book was fraught with inaccuracies, and that orily is examination of the original letters from Wagner to Praeger could scttle the issues raised. 26

Chamberlain then wrote an article for the Bayreuther Blatter which fairly well discredited Praeger's often inaccurate statements--at least among Wagnerites and the musical public. However, there remained yet the troublesome widespread popular reception given the Praeger book. Accordingly, in 1893, while visiting England, Chamberlain by subterfuge secured access to the private archives housing the original Praeger let.ters, and made copies of them. Then, later in Vienna, he wrote more magazine articles, and published in them his copies of the origina Praeger letters. The result was widely accepted as having discreditind

26 The account of this affair is given in "Houston Stewart Chamberlain: Prophet of Bayreuth," pp. 144-151. 
the Praeger book, though hardly enhancing Chamberlain's respectability among non-Wagnerites. With this success, he was able to secure the German publisher's efforts in recalling the book. Advertisements were taken out in the large German newspapers urging buyers to return their copies. But, as Anna noted, since Chamberlain's name by this time was thoroughly identified with the partisan opposition to "Hanslick und Genossen," it was not possible to completely suppress the Praeger book. ${ }^{27}$ Therefore, Chamberlain's own articles and his copies of the Praeger letters were published in a book, Echte Briefe an Ferdinand Praeger (1894). Bayreuthians were satisfied they had done the most possible to maintain orthodoxy, and finally this demonstration of devotion secured Chamberlain his place as the formost champion of the Meisterin, Cosima Wagner. 28

Chamberlain wrote Cosima how Carlyle had praised the obedience a truly great person renders to an even greater idea or individual, the "Loyal obedience to the Heroic." The analogy of himself and even of her toward the Meister was unmistakable. ${ }^{29}$ Thus, the Wagnerian world in the

27 Meine Erinnerungen an Houston Stewart Chamberlain, p. 111.

28 Anna described his work for the Kreis and credited herself as having suggested he begin writing articles on behalf of Bayreuth. She also stated Hugo Bruckmann of the publishing firm in Munich first read Chamberlain in the Bayreuther Blytter, then asked the famous Jewish conductor of Wagnerian operas, Herman Levi (1839-1900) if Chamberlain would be a suitable author for a Wagner biography. While Anna perhaps over-represented her role in her husband's career, she was a faithful co-worker, who apparently even proof read his manuscripts during the years of their estrangement. Ibid., pp. 110-11l. Additionally, she played a substantial role in the English appearance of his books, discussed in Chapter VII.

${ }^{29}$ Chamberlain to Cosima, November 28, 1894, Briefwechsel, p. 391. 
mid-1890's appeared to be prospering, due in no small measure to Chamberlain's own efforts. In 1892, Cosima had established a Bayreuth music school, a much-touted, but short-lived attempt to impart her interpretation of style for the performance of Wagnerian works, based on her recollections and her personal authority as the Meister's widow. For a time it seemed the Festspiele would prosper financially, and in 1896 Cosima staged the Ring for the first time since the first, the 1876, Ring. 30 It appeared Bayreuth had less need of its sturdy band of publicists, and after 1896 Chamberlain attempted to strike out on his own, to establish himself as an authority in his own right, apart from the identification with Wahnfried.

\section{IEBENSLLHRE AND THE FOUNDATIONS}

In December, 1895, Chamberlain decided to resume work on his doctoral dissertation. This was again a sudden decision, but one probably motivated by dissatisfactions similar to those associated with his great decisions in Florence, in Dresden and in Vienna. His unpublished correspondence reveals his sense of limitation in his work publicising Wagner, and friends such as the Swiss Adolf Boissier (18411913) urged him to take a different tack as a writer. 31 During early 1896 he rewrote the results of his Geneva research and published it the next year at Neuchâtel as Recherches sur la sève ascendante. Huwever, he found that the University of' Geneva would still require him to undergo an oral examination before granting him a doctoral degree. The indiglity

\footnotetext{
30 "Houston Stewart Chamberlain: Prophet of Bayreuth," p. 187. ${ }^{31}$ Ibid., pp. 225-226.
} 
of such an ordeal was unacceptable to Chamberlain. He ruefully noted he would henceforth be known not as "Herr Doktor", but simply as "Herr Chamberlain". 32 While this reaction was characteristic of many "outsider" critics in the Second Empire, for Chamberlain it provided the additional advantage of shielding him from a measure of strictly academic criticism. Also, the Bayreuth Kreis had particular reasons for resenting academia: the apostate Nietzsche and the brief academic career of Heinrich von Stein.

The thrust of his dissertation was not the mechanical explanation he had sought with the biologist Graebe in Geneva for sap movement, but vitalism. With the end of the century, many manifestations of dissatisfaction with mechanism and positivist science were popular; these were visible in Chamberlain's views of the movement of sap in plants. He presented his earlier researches and noted the inability of existing mechanical explanatory modes to account for the movement of sap under different pressure conditions. His thinking in this regard was influenced by the reaction to mechanism of many of the century's German scientists, and particularly by his own reading of Lange's The History of Materialism. 33 In vitalist speculations he found confirmation of Goethe's earlier scientific theories, and he proclaimed his own researches were a "negative proof of the existence of the life force." 34

32 Lebenswege, p. 108.

33 This book was seminal for the development of neo-Kantianicm. Frederick Albert Lange, The History of Materialism: And Criticism of its Present Importance, trans. Ermest Chester Thomas, intr. Bertrand Russell, 3rd. ed., in one volume (Iondon: Routledge \& Kegan Paul Ltd, 1865; reprint ed., 1950).

34 "Houston Stewart Chamberlain: Prophet of Bayreuth," pp. 226-r27. 
The inability of science to fully account for phenomena he believed evidence for his own interpretations.

Chamberlain was very proud of his scientific work and was sensitive to criticisms of it. He defended himself in the press against charges he was unscientific, and he utilized his insights on sap movement in constructing his Lebenslehre. 35 Late in 1896 this new area for Chamberlain's thought coincided with an offer from the Bruckmann firm to write a popular history explaining the century to the German public. 36

In six days he sketched out a complete outline for the project, the first part of which he was to follow meticulously. His plan called for three massive volumes, but he was only able to complete the first before he was overtaken by exhaustion. The offer to write came at a time when he was formulating his most important "metaphysical" construct--the Lebenslehre--and he welcomed the challenge of attacking; contemporary problems from the cultural rather than the scientific viewpoint. In the unfinished latter two sections of the projected work Chamberlain hoped to show civilization culminating in the art of wagner. Particularly, he found the encouragement of Cosima Wagner gratifying: When she subsequently found he intended to be his own publishing master, there was a controversy of some moment in the Kreis.

Bruckmann's idea was to sum up the century in a popular edition for distribution by the symbolic year 1900. What academicians previously

${ }^{35}$ Ibid., p. 232 .

${ }^{36}$ In recognition of the influence Wahnfried had in securing the offer, he wrote to Cosima asking her opinion of his ideas for the project. Chamberlain to Cosima, January 18, 1896, Briefwechsel, pp.441-445. 
asked had been found either too reserved or too Ioquacious; Chamberlain offered the required blend of erudition and confidence. The work was expected to take three years, and Chamberlain began research at once. In his memoirs he listed many titles of the books he read during this time, proudly stating that in addition he wrote eight hours a day or more, and kept ideas and references in his journal. On a typical day he consumed, for example, Gibbon's Decline and Fall of the Roman Empire, Drumont's Le Testament d'un Antisemite, Plato's Republic, Natorp's Platos Ideenlehre, etc. He noted down as well any questions he had. He insisted he always followed up any such questions, and through his life read progressively from science and history to theology, as indicated by his publications from the Foundations to Mensch und Gott--with, of' course, the intervening exception of World War One. ${ }^{37}$

Chamberlain was very excited with the great task he had uridertaken; he was to devote the next fifteen years to completing it. He f'ound himself simply outgrowing the narrow bonds imposed by academic specialization, so that the concept, for example, History led hirn to legal history, to church history, to the history of science, to philosophy, and to the sociology of ideas. ${ }^{38}$ But he also managed to keep pace with the couple's busy social schedule, and in this connection, in October, 1896, Chamberlain found himself on a train for Venice, passing through Switzerland. Suddenly overtaken with the inport of his evolving ideas, he got off at the nearest town, Gardone, Italy. There, he worked feverishly for a few days, and drafted a considerab]!

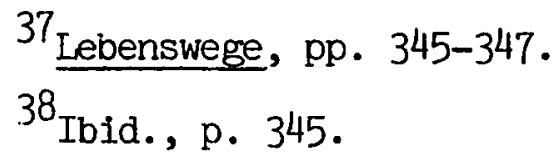


number of sketches. 39 Out of these came important sections for his later Kant, the Lebenslehre, the Foundations and his theological books. Particularly important was the section entitled, "A New Weltanschauung," in which he developed the theme that natural science theory is incomplete without the offerings of metaphysics, aesthetics, religion, philosophy and art. ${ }^{40}$ He blasted contemporary errors of causal thinking, of syllogisms particularly, and stated,

We must secure more freedom for the Anschauung . . . Logic is not the queen of truth, rather its servant; the eye is the king, the ear is the queen, the sense of touch is the wise councilor; through these three mediators we stand in the middle of our environment. 41

His Lebenslehre, thus developed conterminously with the Bruckmann work, never was finished, though he worked on it between 1896 and 1900 . Fragments of it were published posthumously with an introduction by his friend, the biologist Jacob von Uexklli as Natur und Ieben (1928). 42 Particularly enraged at the popularization of Darwinism, Chamberlain saw himself leading the vanguard of a new, post-Darwinian science. He referred to this science throughout his books, yet during his own lifetime only described its actual workings indirectly. It emerged as a division of organic and inorganic sciences in which the empirical and mechanical modes were left with simply inorganic studies. For the remaining areas concerning life, Chamberlain claimed three parts could

39 Meine Erinnerungen an Houston Stewart Chamberlain, p. 115. 40 Lebenswege, p. 127.

${ }^{41}$ Ibid., p. 128 .

42"Houston Stewart Chamberlain: Prophet of Bayreuth," p. 2.34. 
be distinguished. The first area concerned the Gestalt or morphology of life, and utilized a mathmatical reasoning. The second area concerned the functioning of living things and was to be explainable without reference to mechanical parallels or "rudimentary" causal theories. Third was the subject of the Lebenslehre itself; "the science of the Life of Life: the problem of intuiting the fact of life." 43 The result was to become a holistic view of man and nature which combined the material, the scientific and the artistic. The prototype was Goethe's Metamorphosis of Plants and his Theory of Colors. Chamberlain recognized this had been shown to be of no use for nineteenth century science, but with his own reformulation as the Lebenslehre he hoped it would provide the basis for a reconstruction of man's understanding. ${ }^{44}$ The merely "peripheral" concerns of empirical science in Goethe's notion of ideas would be incorporated as raw data, and thus be "fulfilled as they are assimilated under a spirit of humanity. " 45

43 Houston Stewart Chamberlain, Natur und Leben, ed. J. von Jexklll (Munich: Bruckmann, 1928) part 1, p. 34, as quoted in "Houston Stewart Chamberlain: Prophet of Bayreuth," p. 240.

$$
44 \text { Field's conclusion was, }
$$

Chamberlain's mystical attempt, in the light of ideas, to see through nature like a kind of transparancy, and grasp the essence of things, exerted a considerable influence upon the Germanic "scientists" of the Nazi epoch. He called his method "diaphysics" to give it a scientific aura and to di s.tinguish it from "unscientific" metaphysics.

Houston Stewart Chamberlain, "Goethe, Linné und die exakte Wissenschaft der Natur," written for a Wiesner Festschrift in 1907, repr. in Rasse und Personlichkeit (Munich: Bruckmann, 1925), quoted in "Houston Stewart Chamberlain: Prophet of Bayreuth," p. 241.

${ }^{45}$ Lebenswege, p. 150. 
His principal dictum was "Leben ist Gestalt." 46 The invisible, spiritual essence of life was revealed in his Lebenslehre, and this organizing principle of life was Zweckmbsssigkeit or Planm For Chamberlain, understandings beyond mere empiricism could be perceived through intuition. The outward sign of this inward spirituality was race, 48 and influenced accordingly such Nazis as Alfred Rosenberg.

Instead of Darwinian evolution, Chamberlain defined life change as occuring only within the linits of Gestalt, i.e., the definitional framework of life-species. Within the bounds of, for example, hair color, limb structure and mental capability, species life could charge slightly-as long as the "correlation" of the parts to the whole was preserved. The difficulty was that race mixture particularly upset, such a balance. The result was visible to Chamberlain as scientific confusion "as well as ethnic diversity in Vienna's streets:' formless Chaos. " 49

He took from physics the principle of conservation of energy and postulated it as the key to life: "conservation of form" must be retained; no Darwinian evolution was possible. Destruction would be the only result if the basic integrity of organic wholes was not protectced.

$$
\begin{aligned}
& 46 \text { Natur und Leben, p. } 150 . \\
& 47 \text { Tbid., p. } 101 . \\
& 48 \text { The portraitist, Dr. Bllirger-Villingen, was an admirer of }
\end{aligned}
$$
Chamberlain, and in 1912 was inspired to construct a "plastometer, which purported to measure the geography of a human face and thus the cast of a person's soul." George Mosse, The Crisis of German Ideology: Intellectual Origins of the Third Reich (New York: Grosset \& Durilop, 1964), p. 95.

49"Houston Stewart Chamberlain: Prophet of Bayreuth," pp. $243-244$. 
The sustenance of existing life forms was all-important, for in their "symbiosis" they maintained one another's definitional structure. Particularly important was the place in this schema of genius, defined as the higher potential of personality; only through Chamberlain's concept of the "symbiotic" mechanism could true understanding be achieved. 50 From this amalgam of Goethean speculation and contemporary racial theorizing Chamberlain built his cultural critique. ${ }^{51}$

The actual writing of the Foundations, however, took only half the expected time: he began writing in April, 1897, and completed the first draft in August, 1898. The book appeared in 1899 and soon became a huge success. The couple rented a neighboring apartment to enlarge his working area in Vienna, and Chamberlain recorded meticulously every

50

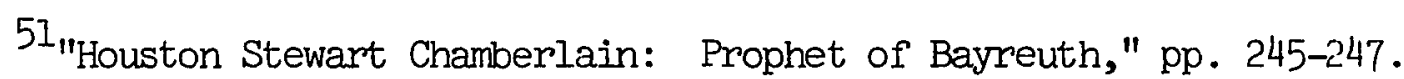
Field gave this sumary of Chamberlain's scientific and cultural notions:

His attacks on scientism and Darwinismus coincided with a world-wide reaction against the abuses of a narrowly scientific outlook. The names of Dilthey, Freud, James, Butler, Nietzsche, Bergson, and Poincare attest to the breadth and profundity of this; movement. But Chamberlain had little in common with these thinker's, although he read many of them and even claimed to find in their works some confirmation of his own attitudes. His thought was an untidy melange of romantic nature mysticism and pan-psychicism, notions borrowed from Schopenhauer and Buddhist thought, others from early evolution theorists and Goethe's scientific works. He began with the Kantian critique of knowledge but soon turned to an irrational, racial vitalism as the basis of his thought. Chamberlain never understood that his Lebensphilosophie represented a revolt against Kantian idealism in that it reunited the world of being and the world of values which Kant had rigorously separated. Chamberlain was the supreme eclectic, taking a little of every cultural tradition for his own purposes. Always more mystically than scientifically inclined, he was quick to abandon science for an intuitive cult of the life force.

"Houston Stewart Chamberlain: Prophet of Bayreuth," pp. 249-250. 
detail of his labors. He found time besides his busy daily schedule of research and writing to correspond with his wide circle of friends. Anna helped copy and correct the manuscripts, and kept the public away from him during his working hours. ${ }^{52}$ In a letter to Hans von Wolzogen he apologized for his absence from the struggle publicising Wagner, but offered the assurance that his work on the nineteenth century would bear fruit: in husbanding his strength for this great project he hoped "this will be a Bayreuther Tat." ${ }^{53}$ He also continued to keep up with contemporary affairs, writing to Cosima about the dangerous growth in Negro and Chinese populations which caused him to re-evaluate Gobineau-important since Cosima remained more sympathetic to the Count than did the optimistic Chamberlain. He noted the Wagner theme expressed in "Heldentum und Christentum" could become (with racial preponderance by such lesser peoples as Negroes or Chinese) a "Mogendymmerung". However, he cautioned that dwelling upon this gruesome end would in itself be pointless, for pessimism is only a function of the brain. For Chamberlain, instead of mere pessimism, what was needed was the Germar colurage to see and the willingness to act. ${ }^{54}$

In the Foundations, Chamberlain traced the major influences he saw acting on his century's culture. He listed Hellenic art and philosophy, Roman law and organization, the Christian evolution, the race mixture resulting from the Roman Empire, the "destructive" Jewish element, and

52 Meine Erinnerungen an Houston Stewart Chamberlain, pp. 119-12\%. ${ }^{53}$ Chamberlain to Wolzogen, December 1, 1896, Briefe I, pp. 44-455. ${ }^{54}$ Chamberlain to Cosima, December 22, 1896, Briefwechsel, p. 494. 
the dominance of the Teutons. The first volume of the book concerned the development of Christian and Greco-Roman cultures to the year 1200. The second volume concerned mainly the Teuton's history to 1800 . Chamberlain claimed to be a "modest historian, who can neither influence the course of events nor who possess ed the power of looking clearly into the future." 55 In examining the "roots" of European culture he traced the polarity of Teutonic genius and Jewish-Catholic "destructiveness." He praised the cultural contributions of the Greeks, but relegated all Greek rationalism beginning with Aristotle to the slagheap of materialism. Similarly selective with the Romans, he praised their tendency toward organization, but decried the "sterile" sociological role played by the late Empire.

In order to deal with Christ he first established the intriguingly complex nature of the Jews. For Chamberlain, the Jews possessed a variegated number of qualities which both determined and were determined by the Jews. These characteristics were: (1) a materialist philosophy (defined as a view of the historical--not the ideal--as the prime mover in life), (2) the secular justice of "legal and moral justification by works" (not through a spiritual seeking or a. metaphysical definition), (3) a limited imagination, (4) no freedom of thought, (5) an intolerance of other religions, and (6) a "red-hot fanaticism". 56 This mixture for Chamberlain was the result of the Jew's singular history. According to him, they had issued from the unnatural miscegenation of Bedouins, Hittites, Syrians and Aryan Amorites. The "original" Semitic profile he saw still perservering with his day's Mohammedans. The Jews had corrupted these peoples, from whose
$55_{\text {Foundations I, p. } 577 .}$
${ }^{56}$ Ibid., p. 440. 
consciousness was thus banished every contemplative wonder, of feeling or superhuman history, creative fancy, and all of the requirements for the nourishing of a religion, save that "minimum" of religion: materialism. He stated, "Where the will has enslaved the questioning understanding and the imagination, there can be no other view of life and no other philosophy than the materialistic." 57

For Chamberlain, normally the Semitic influence would have nurtured a strong race, one he speculated would have been preferable to the mixtures of Bedouins and Syrians, or of Spanish and South American Indians. ${ }^{58}$ However, he sought to show that the Jews became separated from the "Israelite family" by the processes of history. 59 From 701 B. C. to 586 B. C. the idea of racial individuality grew among them, especially when Sennacherib's army broke off its siege of Jerusalem. Further, during the sixty years of the Babylonian Captivity, the last values nurturing the Jews from the old land of Israel were cut off, leaving only a "seething revengefulness" in the Jewish heart. ${ }^{60}$ When Aryan tolerance motivated the Babylonians to allow the Jews to return to Israel, the city of Jerusalem was rebuilt and a state for the Jews was reconstructed. However, a truly independent Jewish state was henceforth denied these people, which circumstance preserved the demented Jewish character.

Under the guidance of a priestly caste the Torah was written, which enabled the survival of the race. This book was a symbol of "the
57 Ibid., pp. 419-420
${ }^{58}$ Ibid., p. 390.
${ }^{59}$ Tbid., p. 359.
${ }^{60}$ Ibid., p. 457. 
ultimate victory of will over understanding and every effort of creative imagination." 61

. . . for to this day, as three thousand years ago, Jehovah is not the God of the cosmic universe but the God to the Jews; he has only destroyed the other Gods, consumed them, as he will one day consume other nations, with the exception of those who shall serve the Jews as slaves. That really is not monotheism but . . unvarnished monolatry. 62

For Chamberlain, Christ was a Jew in religion and education, but not in race. ${ }^{63}$ He gave a lengthy explanation of Jesus' descent from

61

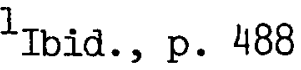
${ }^{62}$ Ibid., p. 425.

63 Chamberlain did not specifically mention that Christ was an Aryan, but suggested as much. For this, Mormsen attacked him and Cosima as well. Letter Chamberlain to Cosima, November 27, 1899, Briefwechsel, pp. 589-590. For this unwillingness to decisively endorse an Aryan Christ, she rebuked him, saying he had begun his chapter on this problem well, and should have continued in the same vein. Letter Cosima to Chamberlain, May 7, 1899, Briefwechsel, p. 564. Chamberlain replied with a very revealing explanation: his real intention was to win greater support for this racist notion, but without alienating those readers who were not yet confirmed anti-Semites:

You would not believe how much-yes, how much renunciation a man in my position must suffer. Were I vain and full of selfpride, then I would write for all eternity. If I wanted more than to have an effect on people and then be floated away in the ocean of forgotten atoms--then I would not do much that I do, arid would do many things that I leave undone. You may object that the right principle is to be 'uncompromising' . . . . But I ask you not to judge too quickly. For if you view my work as a whole you will observe it is an extremely 'uncompromising' work ... . But a concession here and there in small details works wonders and secures admission where one would otherwise be bannedso may the good seed of ideas flourish little by little and the husk (namely the book of the noble HSC with all its imperfections) be left behind.

Letter Chamberlain to Cosima, May 22, 1899, Briefwechsel, pp. 567-568, quoted in "Houston Stewart Chamberlain: Prophet of Bayreuth," pp. 274275. This disarmingly honest revelation bares Chamberlain's careful propagandistic technique of selecting arguments for their effect rather than for any development of ideas themselves: it was a consistent pattern in his mature works which helps to explain many of his quite contradictory references and assertions. 
one of the lost tribes of Israel. This separation from the Semitic branch of Jews is of paramount importance for Chamberlain's links with his day's radical anti-Semites. 64 Chamberlain credited the Jews with discovering the belief in free will and preserving it for the use of later (Aryan) peoples. In contrast to Gobineau's formulation of inevitable degeneration issuing from Jewish and all lesser racial mixtures, Chamberlain ascribed a religious faith and an element of strength and endurance to the Jews. ${ }^{65}$ The malleable concept of race Chamberlain developed in the Foundations allowed him to postulate a new race could emerge at any time through future race mixture:

Every outstanding Teuton is virtually the starting point of a new tribe, a new dialect, a new view of life's problems. There could have been many Teutonic races in Europe had history allowed their development. 66

But Chamberlain as well depicted the regressions possible with the Jewish race:

A man can very soon become a Jew without being an Israelite; often it needs only to have frequent intercourse with Jews, to read Jewish newspapers, to accustom himself to Jewish philosophy, literature and art. 67

For Chamberlain in the Foundations, the Romans had been the first great people to suffer at the hands of the Jews. They had damned their own civilization by extending the rights of citizenship to the varietjes of conquered peoples. The result was a "Chaos of Peoples" which to the present century remained a threat to the Teutons and mankind. When the Teutons conquered Rome, then, they really were attempting to save Ronk.

${ }^{64}$ Chamberlain had an important disagreernent with Adolf von Harrack over this issue, discussed in Chapter VII.

${ }^{65}$ Foundations I, p. $420{ }^{66}$ Foundations II, p.199. ${ }^{67}$ Ibid., p. 491. 
In this attempt they sacrificed their own individuality. Bringing as the Teutons did tolerance and reverence for religion, their reward was simply mongrelization. The Teuton was turned against himself, he who, - . entered history not as a barbarian but as a child-as a child that falls into the hands of old experienced libertines. Hence it is that we find un-Germanic qualities nestling in the heart of the best Teutons . . .68

To the useful Greek value of individualism and the equally valuable Roman organizational genius, the Teuton brought the concept Treue. For Chamberlain, as for many vblkisch thinkers, this concept was vital: even "the negro and the dog serve their masters", but it is the singular characteristic of the Teuton that he alone "chooses his master and his loyalty is therefore loyalty to himself: that is the man who is horn free." 69 This

- . Germanic loyalty is the girdle that gives immortal beauty to the ephemeral individual, it is the sun without which no knowledge can ripen to wisdom, the charm which alone bestows upon the free individual's passionate action the blessings of permanent achievement.70

While, for example, the Greeks had seen the "realm of impulses as a theoretical idea" which only explained existant natures, for Chamberlain the Teutons widened and deepened the ideal, making it a "practical idea to bring about by our active and passive attitudes that which is not, but yet may be." 71

The Teutonic peoples for Chamberlain comprised originally the "northern European races" of Teutons, Celts and Slavs. 72 The Germanic Slav was the "Elder Brother to the East" visible, for example, when ir the tenth century King Michael of Bulgaria secured Byzantine inslead of'

$$
\begin{aligned}
& { }^{68} \text { Ibid., p. 535. } \quad{ }^{69} \text { Ibid., p. 547. } \quad{ }^{70} \text { Ibid., p. 5\%0. } \\
& { }^{71} \text { Ibid., p. } 551 . \quad 72 \text { Ibid., p. } 527 .
\end{aligned}
$$


Roman recognition for his church: this assertion of individuality protected the Bulgarians from the Roman Imperium which (at this late date) "was born of the Chaos, and represented the anti-national, antiindividual leveling principle."73 In the late nineteenth century Chamberlain saw, for example, a continuous formation of religious sects in "Little Russia" indicative of the active inner religious life of Teutonic peoples. He did not see a similar process in Latin nations. Particularly important to his historical process was the role of the Roman church. Parallel to the racial degeneration which came with Empire, the Church descended from the inwward, ideal-seeking values of Jesus to the materialistic philosophy of the Jews. Chamberlain's hero was St. Paul, who was not really a Jew, but a diaspora Greek who had "an un-Jewish soul with pinions fettered to a Jewish thinking machire." 74 With his death, only the Jewish elements remained in his writings, the "dogmatically chronistic pharisaical theology of the one Paul", whereas the Aryan Paul with "a transcendental faith behind the mysterious mi rage of. ermirical appearance" was lost. ${ }^{75}$ To Chamberlain even Augustine wais simply shocked by the events of his time: he opted therefore for an authoritarian church. This aided the history of bloodletting paradoxically stemming from the Roman Empire's having accepted Christianity: "the union of the Aryan spirit with the Jewish and that, of both with the madness of the chaos that knew neither nation nor faith. ${ }^{76}$ In order to hold the faith of the Chaos peoples, the church "lowered itself to the level on which it stood in Judea": to the status

$$
\begin{aligned}
& { }^{73} \text { Ibid., p. } 509 . \\
& { }^{76} \text { Ibid. , p. } 70 .
\end{aligned}
$$


of a materialistic religion. 77

Before the final victory of the Roman Church, Chamberlain saw Charlemagne as struggling to preserve Teutonic values. Charlemagne was a practical politician and well-meaning Aryan; during his reign he limited the Pope's influence in his lands, and was comparable to Goethe in that "Both rode a tilt against the powers of Chaos; both were artists: but both were unable to stem the tides of anti-Teutonic power. ${ }^{78}$ Chamberlain saw the reason for the Church's success resulting from its appeal to the masses, requiring "neither greatness of character nor independent thought" but simply obedience. 79 From the Jews the Roman Church borrowed mystical speculation (however bereft of its "plastic significance" for Chamberlain) and from the Germanic peoples it took earnestness and mystical rapture. 80

With the Renaissance and the Reformation Chamberlain saw the Teutonic Spirit again asserting itself in European history. This was marked by a proliferation of religious sects similar to those he saw in his own day: both periods promised a future age of awakening. Accordingly, Dante and Loyola were opposed representatives of the Aryan and the mysterious Basque semitic race. The Reformation was thus not, an ecclesiastical event, but a "revolt of our whole nature against alien rule, of the Germanic soul against un-Germanic spiritual tyranny." 81 Increasingly in the Foundations Chamberlain pointed to his day's owr Reichsdeutsche as the best representatives (but not the only ones) of" this Teutonic and Aryan evolution. He equated Aryan "inner values," of $\begin{array}{ll}77_{\text {Ibid., p. }} 51 . & { }^{78} \text { Foundations I, p. 327. } \\ { }^{80} \text { Ibid., p. } 122 . & { }^{81} \text { Tbid., p. } 81 .\end{array}$ 
freedom within outward restraint, with Kant and Goethe, and opposed them to the philosophies of Aquinas and Hegel. Similarly in science he envisioned the possibility of overcoming "mechanism." He predicted a glorious future for science when it "discarded the last remnant of the Semitic delusion of understanding, and passes on to pure, intensive intuitive perception, united to free, consciously human shaping." 82 Halfway through his second volume of the Foundations, Chamberlain shifted from discussing the "historical" underpinnings of his T'eutonic vision and increasingly looked toward the culmination of his labors: the contemporary Aryans. He apologized for any misunderstandings engendered during his ascent from the earlier periods of history, and directed the reader to reread earlier passages of the book for clarification. He did "not propose to enter into details. . . for it. has not been my intention to chronicle the past, but to illumine the present." 83

He grouped notable recent Europeans into four categories: theologians, mystics, humanists, and natural scientists--the latter. including philosophers. He claimed this division had the virtue of' allowing him an impartial view of individual contributions. Thus, he himself had "urlimited tolerance toward every sincere, genuinely Teutonic view" not inquiring "about the what of a particular philosophy, but about the how; free or not free? personal or not personal?" 84 By this schema, Teutonic theologians were Duns Scotus, Occam and luther. while St. Francis and Jesus were both theologians and mystics. The function of mystics was to "render the subjectively given material of"

$$
{ }^{82} \text { Ibid., p. 329. } \quad 83 \text { Ibid., p. } 282 . \quad 84 \text { Ibid., p. } 403 .
$$


this world into something objective" while the humanist simply collected and tested "all the different human evidence." 85

Just as in his own life, Chamberlain thus saw in history the need for philosophers to balance their formulations with scientific studies. He stated when philosophers have discarded the "methodology of" Aristotle," they may "disinterestedly perceive truth." 86 His model in modern history was Kant: he portrayed Kant as the fulfillment of the Foundations:

Teutonic philosophy is transcendent, and Teutonic religion ideal; both, therefore remain unexpressed, incommunicable, invisible to most eyes, unconvincing to most hearts, unless art with her freely creative moulding powers-i.e., the art of genius--should intervene as a mediator. 87

What Chamberlain presented as the future possibility was clearly either Aryan or Semitic triumph. However, his definitions were vague, and particularly those concerning "race" vacillated between racial Diktat and environmental process, between determinism and volunteerism. The Foundations was designed to stake out his own claims as a thinker'; only later did he evolve the exclusively reichsdeutsche definition which characterised the extreme v8lkisch group of Germans. In the Foundations, for example, he criticised the biological determinism of Gobineau who "bores like a mole in the dark ground and fancies that from the soil he can explain the flowers, though rose and thistle grow side: by side." 88 And unlike the racial determinism of many late-century Germans, Chamberlain's notions permitted non-biological changes in

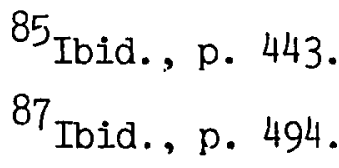
${ }^{86}$ Ibid. , p. 438. ${ }^{88}$ Ibid., p. 206. 
racial status. ${ }^{89}$ Perhaps his inconsistency of this important point was influenced by Richard Wagner's similar uncertainty; both Chamberlain (for his entire life) and Wagner (at least in his earlier and later periods) shared an optimistic view of man. But both utilized pessimistic racial constructs with no great consistency: both devoted themselves above all to the aesthetic realm and to the "potency" of genius and personality.

However, at the time Chamberlain wrote his Foundations, he was certain that regardless of his theoretical framework, he himself had no difficulty identifying Jewish attributes. Basically, Aryans were handsome and Jews were not. Accordingly, "various sources" had established that even small children too young to have been instructed about race would begin to cry if approached by a Jew. ${ }^{90}$ Chamberlain described the typical Aryan, by contrast, as an ideal, a stereotype:

- . the great radiant heavenly eyes, the golden hair, the gigantic stature, the symmetrical muscular development, the lengthened skull (which an ever-active brain, tortured by longing, had changed from the round lines of animal contentedness and extended toward the front) the lofty countenance, required by an elevated spiritual life as the seat of its expression . . . 91

This was, however, only the Aryan prototype. Chamberlain allowed that, this person could have been also dark and short, and even his skull size could vary. The use of cranial measurements-so important for nineteenth century anthropological and mystical siudies--only established

89 This point is cogently made in Herzstein, "The Wagnerian Ethos ir German History, 1848-1933: A Reinterpretation of Richard Wagner's Historical Significance," and in his later "Richard Wagner at the Crossroads of German Anti-Semitism 1848-1933. A Reinterpretation," Zeitschrift fllr die Geschichte der Juden, IV Jahrgang, \# 2/3 (1967): 119-140.

${ }^{90}$ Ibid., p. 537 .

${ }^{91}$ Foundations I, p. 535 . 
"arbitrary" standards. Chamberlain stated measurements only obscured a clear view of race itself. He wrote "Nothing is so convincing as the consciousness of the possession of race." 92

Race is not a mere word, but an organic living thing, it follows as a matter of course that it never remains stationary; it is ennobled or it degenerates; it develops in this or that direction and lets this or that quality decay.93

Chamberlain valued above all the religious and aesthetic spheres; he saw the Teutonic peoples standing in need of a great religion which would unite them in technology and idealism, in individuality and in universalism. He saw "the greatest danger for the future of the Teuton" because "we are not more moral than other people, but much more religious." 94 The Foundations was to be a signpost on the path to future racial greatness. And, ironically, he prided himself as not having constructed a mere monocausationist history, since

... nothing is more dangerous than the attempt to construct history from a single principle; nature is infinitely complex; what we call race is within certain limits a plastic phenomenon, and, just as the physical can affect the individual, so too the intellectual may affect the physical.95

It was this vacillation about race which Ludwig Schemann, felluw publicist for Deutschtum and early friend of Bayreuth, could not abide. Having--at the suggestion of Richard and Cosima Wagner-introduced Germany to Gobineau and f'ounded the Gobineau Verein, Schemann remained an adherant of' the Count 'is pessimistic determinism. Thus, inspite of his many interests in common with Chamberlain, even Schemann wrote bittorrly,

Chamberlain became. the leader of all those who need for their quickening a stronger dose of illusion without which nothing on earth can be accomplished. 96

$$
\begin{aligned}
& \text { 92 Ibid., p. } 429 \quad 93 \text { Ibid., p. } 297 . \quad 94 \text { Fourdations [1. p. 2.5\%. } \\
& 95 \text { Ibid., p. 373. } \quad 96 \text { Der Bayreuther Kreis, p. } 122 .
\end{aligned}
$$


CHAPTER VII

DER FALL CHAMBERLAIN

THE BOER WAR AND KAISER WILHELM II

Finished with writing the Foundations in the late summer of '1898, Chamberlain was exhausted. He vacationed in Salzburg, realized he would not be able to undertake two more such books, and decided to change the name of bis book. He telegraphed Bruckmann, who was preparing the maruscript for publication, that instead of being titled The Nineteenth Century: Part 1, it should be The Foundations of the Nineteenth Century. This new title expressed the comprehensiveness of his efforts without requiring him to actually deal with the nineteenth century itself. ${ }^{1}$ Upon publication of the book, Chamberlain found himself a public figure. It sold over 100,000 German copies by $1914,^{2}$ was translated into Crech, English and French, and totaled over 30 edition. It made him the paramount synthesizer of the Bayreuth ideas of art, religion and Deutschtum, recognized for his own formulations, beyond the conf'ines of' the Bayreuth Kreis. 3

The day was psculiarly receptive to such an amalgam of illogical

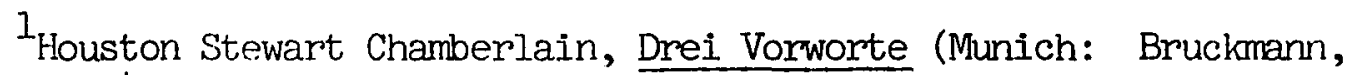
1923), p. 24.

${ }^{2}$ Michael D. Biddiss, "Houston Stewart Chamberlain: Prophet of Teutonism," History Today, January 1969, p. 16.

3 Der Bayreuther Kreis, p. 125. 
reasonings but erudite quotations as was the Foundations. By the late century, the v8lkische, romantic and nationalist traditions in Germany had nurtured a distinctive nationalism. Chamberlain epitomized the alienated late-century aesthete, preaching irrationalism as he did within a seemingly-reasonable cloak of respectability. He contributed to the preparation of a "streamlined Romanticism." 4 While most respectable academicians in Germany ignored or disparaged his book, some f'avored it, and the popular press rapturously welcomed it. 5 Even the foreign reception was not greatly unfavorable--at least before the World War. ${ }^{6}$ The Foundations appeared when the German drive toward world power was colliding with British naval superiority, when the Navy League and the Pan German League were pressuring stridently for a more assertive German role in the world. ${ }^{7}$ The book contributed greatly as well to the fin de siëcle European revival of anti-Semitism: "No book then perhaps had the wide influence of anti-Jewish teaching as did this

4

This phrase comes from Viereck, Metapolitics, which is valuable for insights into the issue of "Proto-Nazis" but is unreliable for facts.

5 Field devoted Chapter VIII, pp. 357-420, to a discussion of the Central European reaction to the books' publication.

6 In America, for instance, the historian Carl Becker complimented this "man who has something more than opinions that are 'well documented!" "Review," The Dial, 50 (16 Nay, 1911), p. 387. Theodore Roosevelt. also praised the "brilliance and suggestiveness" of the Foundations, but noted Chamberlain's doctrines were based upon foolish hatreds, continually contradictory, the whole revealing Chamberlain as a man "whose brilliant lapses into sanity are fixed in a matrix of fairly bedlamite-passion and non-sanity." Theodore Roosevelt and Lyman Abbott, review of "The Foundations of the Nineteenth Century by H. S. Chamberlain." The Outlook, (29 July, 1911), p. 729.

7 Mildred S. Wertheimer, The Pan-German League, 1890-1914 (New York: Columbia University Press, 1924), p. 92. 
book with its harmless cultural-philosophical title."8

Students of the "politics of cultural despair" have recognized a commonality of the writers Iangbehn, Gobineau, Chamberlain, Spengler, Moeller van den Bruck, and Alfred Rosenberg. These writers shared a common usage of Gibbon's model, the "decline" of Rome. They differed as to interpreting this "lesson" of history. It was Chamberlain's optimistic praise of the Aryan in the Foundations which endorsed Prussian leadership of the Reich; his confidence in the German future implied the day's internal and external problems could be surmounted. To ensure this Aryan future, Chamberlain continued to labor with his writings for the next decade and a half. His faith in Germany remained distinctively firm.

However, busy as he was with writing, contemporary affairs did not pass him by. While writing the Foundations, he and Cosima had discussed, for example, the recent death of a Wahnfried friend, Clement Harris, in the Greek-Turkish war. They shared the opinion this man's demise was comparable to Byron's: while tragic, at least it had been in the service of' a great idea. This they contrasted with the contemporary British policies in southern Africa. ${ }^{10}$ In the case of south Africa, he and Cosima saw linked the policies of "Papist" Rome, materialistic Fingland, 8 Bein, "Der. Moderne Antisemitismus und seine Bedeutung fur die
Judenfrage,"

9This phrase comes from the title to Fritz Stern's The Politics of Cultural Despair: A Study in the Rise of the Germanic Ideology. It is expressive of the attitudes of this diverse number of cultural critics. Field was one of Stern's students.

${ }^{10}$ Chamberlain to Cosima, May 19, 1897, Briefwechsel, pp. 511-51?. 
and the Jews. ${ }^{11}$ She noted the contrast of these crass deeds with Chamberlain's noble book, a book which she said had "a particular meaning, especially to us [at Wahnfried]."12 Soon he was pleased to relate to her that in Berlin his Foundations was on the reading table of every educated person and was significant in important discussions. The despised British policy in south Africa around the time of the Boer War (1899-1902) provided many Germans with "proof" of the assertions Chamberlain had made in the cultural context of his writings. But the war as well added difficulties for the author himself, causing him to disassociate himself from his homeland's war policy: it drove him to stricter definitions of Aryanism. By the next decade he was to confirm that only reichsdeutsche were to be truly included within the concept Teuton. Cosima, among others, nurtured his narrowing viewpoint. ${ }^{13}$ She suggested to him that the Boer War was really the work of the "Jew" Rhodes and "Rothschild and company" rather than of genuine Englishmen. ${ }^{14}$ This anticipated Chamberlain's eventual affirmation that England, not he, had changed. ${ }^{15}$ He replied to her that the Conservative leader, Lord

${ }^{11}$ Cosima to Chamberlain, May 25, 1899, Briefwechsel, pp. 569-570. ${ }^{12}$ Cosima to Chamberlain, October 8, 1899, Briefwechsel, p. 579.

${ }^{13}$ Cosima was considerably more outspoken and extreme than was he. She urged him to make more definite conclusions on many matters, for example writing, "I believe you do not know how really right you are: a German marries a Jewess, a Mischling comes into the world; the Mischling marries a Mischling, and a pure Jew results! So it goes!" Letter, Cosima to Chamberlain, November 30, 1902, Briefwechsel, p. 654.

${ }^{14}$ Cosima to Chamberlain, March 1, 1900, Briefwechsel, p. 589. ${ }^{15}$ Chamberlain to Cosima, November 29, 1899, Briefwechsel, p. 581. 
Salisbury, had been corrupted in his youth by Jews, and was increasingly surrounded by well-born and cultivated "Parvenus". 16 With similar reasoning, when the Foundations was banned by the censors in Russia, Chamberlain decided this restriction was the result of his frequent quotations of Goethe, Kant and Eckhart, not because of his anti-Slav orientation. 17

When he visited England in 1900, he termed it the "Iand of the Boer-eaters" which was the result of several centuries of Jewish politics and the dominance of Jewish industrial and political interests. 18 Cosima responded to him regarding this "illegal" Boer War and the English victory: "This destruction of a worthy German tribe is so grisly that I cannot compare it with any event in my lifetime."19 Chamberlain even ascribed a lessening of interest on his remaining, English capital to the war: when soliciting money he claimed this explained why he had no money in the house and could not even attend the Bayreuth Festspiele. ${ }^{20}$ A poem he wrote interpreting the Boer War included this second verse:

War I view as unholy When the German in blind delusion Unfurls the flag against Germans. The poisoned metal, maliciously hurled Recoils murderously against his own heart; He who i robbed of the godly spark, Falls not alone; with him fall

${ }^{16}$ Chamberlain to Cosima, December 12, 1899, Briefwechsel, p. 581. ${ }^{17}$ Chamberlain to Cosima, December 23, 1899, Briefwechsel, p. 585. ${ }^{18}$ Chamberlain to Cosima, September 16, 1900, Briefwechsel, p. 605. ${ }^{19}$ Cosima to Chamberlain, September 20, 1900, Briefwechsel, p. 605. ${ }^{20}$ Chamberlain was exaggerating in this letter to solicit sympathy 
All his sons in the womb of time, Future builders of eternity;

He who dies, has had some effect, but those unborn

Remain forever lost to few noble ones!

When German battles German:

Whoever wins; God is defeated. 21

Now, not content to simply bask in his new-found public favor, Chamberlain resumed work on a project he had begun earlier in Vienna, a Goethe register, which he used later when he wrote his own book on Goethe. But in 1900 he decided to resume writing, instead, along the lines he had anticipated three years earlier in Gardone, Italy. Again, he explained that an incident seemed to direct him toward his new task. On April 27, at 3:30 in the afternoon, he was walking near an optical. factory in Vienna, and was overwhelmed by the vision of writing a book about Kant. He became so excited that he ran home and began to write at a furious pace. ${ }^{22}$ He posted a sign on the door of the couple's apartment, "Mr. H. S. Chamberlain accepts communication only by letter or by introduction with Mrs. Chamberlain." Later he added (in English, to heighten the effect) "My Home is My Castle."23

and funds. Field discovered Chamberlain actually was increasingly the recipient of both gifts (for example, this visit to England in 1900 was paid for by relatives) and royalties from his publications. However, in this letter, he even blamed his brother, Basil Hall Chamberlain, in Japan for utilizing monies which otherwise he might have enjoyed. Letter Chamberlain to Bult von Steyerm, March 10, 1900, Briefe I, p. 87.

${ }^{21}$ Published in Hardens' Die Zukunft, Berlin (February 17, 1900), p. 291, and in the Ostdeutsche Rundschau, Vienna (F'ebruary 18, 1900), quoted in "Houston Stewart Chamberlain: Prophet of Bayreuth," p. 486.

22 Lebenswege, pp. 132-133 and pp. 292-294.

23 Meine Erinnerungen an Houston Stewart Chamberlain, p. 124. 
While working on this Kant book, Chamberlain continued to publish a wide variety of magazine articles and other books as well. In 1900 his Parsifal Marchen was published, written at the inspiration of Cosima Wagner, and he wrote an article about the Rumanian Jews. ${ }^{4}$ In 1902 he published a collection of religious citations, Worte Christi, at the suggestion of two aristocratic friends: Countess Marie Zichy, wife of the Hungarian ambassador to Vienna, and Baroness Marie WallersteinOetingen, a prominent socialite. ${ }^{25}$ Chamberlain's theological speculations were further developed in Mensch und Gott (1921) which found great favor with another student of theology, the then ex-Kaiser, Wilhelm. Likewise, in 1902 Chamberlain sought to establish his reputation as a creative writer with some short plays, Drei Bthnendichtungen.

In these later Vienna years, after the publication of his Foundations, there developed a Chamberlain "Kreis". His many admirers would gather for "reading evenings" and discussion. Guests were Leopold von Schroeder, Count Brockdorff-Rantzau, Count U1rich von Bllow, brother of Germany's Chancellor, many other Wagnerites, and the

24 "Ueber die Judenfrage in Rumgnien," published in Nuova Revista Romana, Bukharest, vol. 10 (1900). This article was printed in Germeny only with great reluctance in 1901 because Chamberlain's publisher, Bruckmann, believed book sales would be harmed. Letter, Chamberlain to WiIhelm II, February 20, 1902, Briefe II, p. 164. The article was solicited by the Rumanian journal of foreign writers to consider whether civil and political equality should be restored for the Rumanian Jews. Chamberlain believed himself a "moderate" on the sub,joct, and his article pleased anti-Semites in 1900, as it did when it we:s republished during the First World War as part of his propaganda work, aescribed in Chapter VII.

${ }^{25}$ Meine Erinnerungen an Houston Stewart Chamberlain, p. 126. 
new young friends Hermann Keyserling and Rudolf Kassner. ${ }^{26}$ Keyserling eventually broke away from Chamberlain's influence, achieving a reputation as a mystic philosopher after the World War. Keyserling's first book, Gefluge der Welt, was heavily indebted to Chamberlain's magnetism and his formulation of philosophy. ${ }^{27}$ Kassner was a music critic, also influenced by Chamberlain in his own book, Die Moral in der Musik. But by 1908, he too became more involved with mysticism and drifted out of the extremely personalized atmosphere of the Chamberlain acquaintances. Field described these friendships as crippled by Chamberlain's nearly maternal ingratiating helpfulness toward youngern friends and his dogmatic refusal to tolerate dissent from his own structure of beliefs. ${ }^{28}$

Thus the first years of the new century in German speaking countries saw a "Chamberlain Case": his Foundations sold well in spite of its expensive early editions, and continued to receive wide praise

26 Discussed, for example, in Meine Erinnerungen an Houston Stewart Chamberlain, pp. 126 and 149. A friendship unexplained, however, was that with a young Jew, Otto Weininger. Weininger was a masochist homosexual who received his Ph.D. and published Geschlecht und Charakter in 1903. He synthesized the remarkable opposition of Jewish, feminine England to heroic Germany. He sought a new messiah who would redeem the world from the guilt of womenishness, the Jews, Anarchism, Communism and the materialistic interpretation of history. Under Chamberlain's influence, the 22 year old Weininger formulated and followed the dictum, "Free the world from Jews," killing himself later in 1903. Quoted in Friedrich Heer, Gottes erste Liebe: 2000 Jahre Judentum und Christoritum genesis des Osterreichischen Katholiken Adolf Hitler (Munich: Becht].e, 1967), pp. 334-335. Chamberlain was distraught at the suicide.

27 Evidently Houston's second wife, Eva, later destroyed the Keyserling correspondence. "Houston Stewart Chamberlain: Prophet of Bayreuth," fin. p. 508.

$$
{ }^{28} \text { Ibid., pp. 385-387. }
$$


in Europe. 29 Cosima and Chamberlain agreed the failure of his subsequent books to sell quite as well was due not to the increasingly specialized subjects they dealt with, but to a conspiracy organized principally by Jews. She wrote, "A book such as the Foundations must be attacked by a concerted drive: Jews and Jesuits and Socialists and Professors and Atheists, etc., etc., etc." 30

The greatest of many (ferman admirers of the book was the Emperor of Germany. The Kaiser had become an enthusiast of Bayreuth in his youth, in 1884 having taken the Richard Wagner Verein in Prussia under his personal protection as Crown Prince. ${ }^{31}$ He had read with great interest Chamberlain's essays (particularly his "The Prussian Race" in 1900) and the two Wagner books. In 1901 he read the Foundations and wass enthusiastic. Count Philipp Eulenburg, German ambassador to Vjenna and close confidant of the Kaiser, wrote to Chamberlain, and invited him to the embassy for a discussion and later to meet the Kaiser at his hunting, lodge in East Prussia. On this occasion, Chamberlain also met the Chancellor, Count Bermhard von Bllow (1849-1929), and the member's of the royal entourage. The Kaiser thanked Chamberlain "for everything you have done for Germany." 32 Further, he invited him to come with the royal

${ }^{29}$ For the first few years of the new century the book was a bent seller of dimensions comparable to Spengler's later Decline of the West. Hans Kohn, The Mind of Germany; The Education of a Nation (New York: Charles Scribner's Sons. 1960), p. 268.

${ }^{30}$ Cosima to Chamberlain, March 23, 1901, Briefwechsel, p. 615. 31 Der Bayreuther Kreis, p. 140.

32 Meine Erinnerungen an Houston Stewart Chamberlain, p. 135 . 
party to meet the Kaiserin at Potsdam the following day. On this occasion the Kaiser made a great point of assembling the entourage with Chamberlain in a large hall where he pointed to a table and proclaimed, "That is the historic table at which I read your Foundations to a small group of listeners." 33 Chamberlain gave some proofs of Worte Christi. he had brought to the Kaiserin, who perused them that evening. Meanwhile, the men smoked and drank wine until midnight, discussing their common interests. The Kaiser solicited Chamberlain's opinions and displayed a photo album of his current favorite project, the Baghdad railway. When one of the group questioned Chamberlain closely about the Foundations, the Kaiser interrupted, and asked if the man had read the book. When the answer was in the negative, the Kaiser said with authority, "First read the book, then speak more to us about it." 34

There was, thus, a great deal of shared belief between Chamberlain and Germany's erratic ruler. Wilhelm sent him a copper engraving which depicted an incident in the recent Boxer Rebellion, when a regiment of badly needed German sailors had arrived, and the commanding English General ordered, "Germans to the front!"35 'Thejy. correspondence was formal and laudatory, sent usually by personal courier, and lasted for the next twenty-six years. It appears Chamberlain encouraged some of the most virulent Deutschtum and Macht:

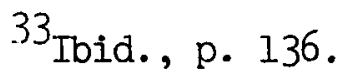
${ }^{34}$ Ibid., p. 136.

35 The 1900 Boxer Rebellion began with a massacre of Christians and the murder of the German representative in Peking. The European response of nationalistic-minded men such as the Kaiser was aptly charaterized in the engraving he gave Chamberlain. It was described in Meine Erinnerungen an Houston Stewart Chamberlain, pp. 133-134. 
notions the Kaiser so extravagantly displayed. As did many patriotic. Germans, Chamberlain lauded the moral superiority of Germany. In 1901 he wrote to the Kaiser that the "positive Realpolitik" of the Second Empire was different from that of other nations, since it was organized not from the common mistaken notions of mere statecraft, but from the "standpoint of a moral world order." Further, Chamberlain maintained this necessitated a struggle against the divisive poisons of Jewishness, Ultramontanism, materialism, Slavic superstition, etc., on behalf of the German "reine Kraft of faith." In this context, for Chamberlain, the Second Reich challenged the pervasive influence of a "yankeeisierten Angelsachsentums" as well as of a "totalisierten Slawentums. "36 The Kaiser responded with equal praise, thanking Chamberlain for his suggestions on reading material, stating Chamberlain's "pure struggle bringing order into a world of confusion, light into darkness" was most appreciated. The Kaiser saw Chamberlain's letters as a "costly jewel," useful in the struggle to awaken the "German Michel." He depicted himself as wielding the sword while Chamberlain used the pen: both men engaged in a common struggle. 37

The two enthusiasts agreed their relationship was comparable to Voltaire's correspondence with Friedrich the Great, and wide publicity of this analogy was given in Germany. Chamberlain recommended many books and articles to Wilhelm, for example, his own "England and Germany" (1.903) which he described to the Kaiser as outlining a program for (Germany as the "heart of mankind." In this article, Chamberlain stat,od

${ }^{36}$ Chamberlain to Wilhelm II, January 18, 1901, Briefe II, p. $1 \%$.

37 Wilhelm II to Chamberlain, December 31, 1901, Briefe II, pp. $157-158$. 
the future lay with German concentration and organization, since while the Anglo-Saxons could use political atomism to unify their national efforts, they had no true inner freedom; the Germans, however, had Geistesbildung and freedom, but were sufficiently contaminated with Slavic blood as to require a more organic national framework than did England. Most particularly, Chamberlain and the Kaiser agreed on the formulation of German freedom, which they saw manifest in heroes such as Friedrich the Great. This concept was of "unlimited freedom of thought, religion and science, but not the freedom to harm oneself: 'Outwardly limited, inwardly unlimited'". 38

Wilhelm II noted how he gave copies of the Foundations to his friends, and said that particularly many young military officers were attracted by its powerful synthesis. 39 Chamberlain told the Kaiser, in his turn, that the "dollar orientation" of England and the United States wold d come to nothing in comparison with German superiority; in 50 years the English nobility would be simply a purely "money oligarchy" with no racial solidarity or organic relation to the throne. 40 Strongly emphasizing Germanic religion, Chamberlain told the Kaiser how he opnosed

${ }^{38}$ Chamberlain to Wilhelm II, February 20, 1902, Briefe II, pp. 157-158.

39 Because of the publicity given to the close friendship of the two, many contemporaries believed the Kaiser underwrote the book. However, it was a south German industrialist, August Ludowice, who donated 15,000 marks for distributing the book to libraries and schools. Letter, Wilhelm II to Chamberlain, December 21, 1902, Briefe II, p. 66. For. example, the French writer Ernest Sellilere's Houston-Stewart Chamberlain: Te plus récent philosophe du Pangermanisme mystique (Paris: La Renaissance du Libre, 1917), p. 157, stated the Kaiser financed the book.

${ }^{40}$ Chamberlain to wilhelm II, February 4, 1903, Briefe II, p. 169. 
any culture which did not completely accept his definition of Christ. He wrote that the enemies of Christ were his enemies, whom he would not suffer to educate children, be models for the youth, or to run the government. ${ }^{41}$ Chamberlain continually praised the role of the Kaiser in Germany, damning the contemporary influences both men found divisive. ${ }^{42}$ Their relationship was sincerely based on common passions, hopes and fears. 43

BOOKS, DIVORCE AND REMARRTAGE

Chamberlain was the writer after 1900 for the "orthodox" school of German nationalists. He was not overtly to move to the extremes of such "outsiders" as Lagarde, Langbehn and the Schn४rers. He was not as viscious in his outbursts as Eugene Dllhrung, not a paganist like Ludwif Klages, nor was he a mystery-fanatic like Alfred Schuler. ${ }^{44}$ He

${ }^{41}$ Chamberlain to Wilhelm II, March 27, 1903, Briefe II, p. 210.

${ }^{42}$ Chamberlain cited a visit his brother Basil had had in America with President Roosevelt in 1908. The President asked Basil (who had just returned from Japan) how it was the Japanese were able to so swiftly and effectively utilize their national might. Basil answered, "because they have got ideals, Sir." Houston used this remark as an illustration of how Germany stood in the line of idealistic greatness from Greece: with the Wagner heritage and the direction of the Kaiser, the Germans would themselves "have ideals" and achieve their full potential in the world. Letter, Chamberlain to Wilhelm II, September 25, 1908, Briefe II, p. 229.

${ }^{43}$ Field discussed their relationship as well in terms of their contrasting temperaments; the emperor admired Chamberlain's English background while Chamberlain admired the German heritage. "Houston Stewart Chamberlain: Prophet of Bayreuth," pp. 392-406.

44 George Mosse has discussed the influence of a variety of strange groups and men before the World War who brought to the public visions of mystic possibilities. The concatenation of race, religion, voluriteerism, organicism, anti-historicism, etc., became the volkische union. Itss popularity was a measure of the disaffection of the times. The 
continued to publish works which depicted a spiritualization of Germany, transforming his heroes. Tacitus' ancient Germans, Eckhart, Luther, Kant, Goethe, the War of Liberation Heroes, and Wagner became his models of Deutschtum. However, the difficulties were enormous. The Wilhelmine reality he attempted to mold with his writings was in feict materialist, positivist, torn by Liberalism and Socialism, and was even tiring of the Bayreuth cult. "Wagnermuligkeit" denoted the satiation of many fin de siècle Germans who hoped for some real, concrete greatness-not merely of the aesthetic variety. This "proud Tower" 45 was at once fed and attacked by Chamberlain's cultural criticism. 46

His literary activity continued to be great in the first decade of the new century. He published new introductions to later editions of his Foundations in 1901, 1903 and 1912 which deepened his identification

publisher Eugen Diedrichs encouraged a broad spectrum of theosophical and vblkische writings which considered popular theories of "electric current" emanating from the "cosmic aether," etc., where "the will signifiec that personal dynamic which was the cement of the volkische faith. Such considerations reflected a Kantian influence, on the one hand, and a Nietzschean re-emphasis, on the other." Commenting about the "Sera Circle" around the publisher Diedrichs, Mosse observed, "It, is surely significant that ideas, cults, and theories which in the rest of Europe were simply passing fads became associated in Germarly with serious world views." Mosse, The Crisis of German Ideology, pr. 58-65.

45 This is the title of Barbara Tuchman, The Proud Tower: $\Lambda$ Portrait of the World Before the War 1890-1914 (New York: The Macmillan Company, 1962). She explained this phrase from Poe was illustrative of a fin de siècle attitude preferring the risk of war'"s modern hazards to domestic unrest or the post-1815 European peace.

46 Chamberlain stood especially high in the pantheon of mainstream and radical German youth groups. With Langbehn, Lagarde, Gobineau and Adolf Bartels he was a link to the more centrist nationalists, for example, Boeckes, St8cker and Otto Anmon. Mosse, The Crisis of German Ideology, pp. 24-25. 
with things German. Also in 1903, with Friedrich Poske, he published Heinrich von Stein und seine Weltanschauung. His Immanuel Kant. Die Persönlichkeit als Einfuhrung in das Werk ${ }^{47}$ appeared in 1905, as did a small book about Indian religion, Arische Weltanschauung. He continued to produce a great quantity of magazine articles on the same themes, and in 1912 completed his Goethe. ${ }^{48}$ He maintained he was an independent writer, willing to state his relationship to Bayeruth in private correspondence but not in his most popular book, the Foundations. ${ }^{49} \mathrm{He}$ enjoyed his new-found position immensely as "Houston Stewart Chamberlain der Deutsche. $"$ "50

${ }^{47}$ Herzstein credits Chamberlain's Kant as "a brilliantly successful study of the meaning of Kant's philosophy which is still [1964] valuable to the serious student of German thought." Herzstein, "The Wagnerian Ethos in German History," p. 297. This view is somewhat exaggerated. The Kant book is loaded with the same ideological constructions as were Chamberlain's previous books, and while it illustrates his own notions, it is not critically accepted by most serious writers. As Herzstein says, it indeed may be usefur as a "document" on German thought of the period.

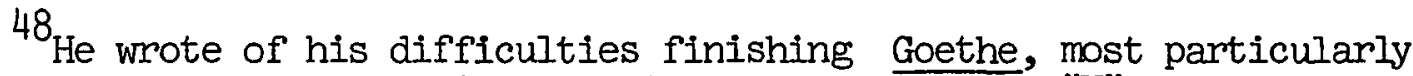
that he wrote more easily without being in the Viennese "Vylkerchaoskapital," and that Cosima was particularly interested in seeing the book completed and published. Chamberlain to Hugo Bruckmann, March 29, 1912, Briefe I, pp. 201-206.

${ }^{49}$ He wrote to Cosima he was certain "that I belong to Bayreuth, as long as I breathe-that I can do no otherwise, as long as I yet have life." Chamberlain to Cosima, May 12, 1901, Briefwechsel, p. 617.

${ }^{50}$ Chamberlain had a faultless reading voice and excellent pronunciation in English, German and French. He was an engaging conversationalist and had a sense of humor. For example, in his memoirs he related an incident when he had met a certain professor Krumbacher who had unfavorably reviewed the Foundations. Initially there was a strained silence between the two men, but then the house they were in was plunged into darkness. The only recently-introduced electricity was as yet a novelty: Chamberlain was the only one present who had any understanding of the problem. He promptly changed the fuses, restoring power to the lights. At this, the professor was greatly impressed, and 
His letters with Cosima remained formal and worshipful, and the two could agree about such happy events as the Bayreuth visit of Isadora Duncan ${ }^{51}$ as well as about such "injustices" as the New York performance of Parsifal in 1903.52 But what Chamberlain could not see was obvious to the Kreis: his greatest inspiration was Richard Wagner and the Bayreuth Idea. Accordingly, Henry Thode (1857-1920), cultural historian who had married Daniella von Bllow in 1886 and was devoted to

asked how it was Chamberlain knew of such things as electricity. Chamberlain responded that this was among his talents as well as was his achievement of writing the Foundations. With this, he and the scholar became fast friends, and Chamberlain concluded the "moral" of the story was that he was not simply a "bookworm," but many other things (i.e., an electrician and man of the world) as well. Lebenswege, pp. 318-319.

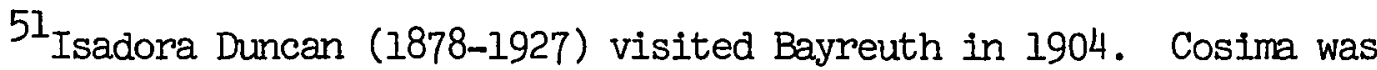
delighted with her, calling her "an exemplary member of the Anglo-Saxon race" who enjoyed particularly the gracefulness of Tannhduser, and was very interested in the Bayreuth stagings. It was ironic that Cosima would recount this to Chamberlain since the very scenes in the opera Miss Duncan praised were "typical" opera-not the Gesamtkunstwerk which Bayreuth was so seriously promoting. Cosima to Chamberlain, June 4, 1904, Briefwechsel, p. 671. Another insight into Cosima and Chamberlain's deepening views on the Meister's art was their opinion of such comic opera as Mozart's Cosi fan tutte. Chamberlain wrote her he had just seen a performance of this opera in Munich, and he was appalled: it was an offense against music, an "unaufhbrliche Dusche", consisting of simply one aria strung together after another, using every sort of instrumentation, assembled without any organic inspiration whatsoever. He complained their own day saw many such creations, and indicated he had begun a sketch for a history of music along the lines of a Bayreutrer Grundlage, with the title in mind, "Die Klassiker der deutschen Tondichtung: Bach, Mozart, Beethoven, Wagner." Chamberlain to Cosima, August 8, 1897, Briefwechsel, pp. 517-518. Cosima responded that she wholeheartedly agreed with him, and even extended the darmation of Mozart's light works: as well as Cosi fan tutte, Don Juan and Figaro were as bad as the Italian operas--simply termible. Cosima to Chamberlain, September 9, 1897, Briefwechsel, p. 520.

52 This work had been intended by Richard Wagner for Bayreuth alone, a religious work of art, the Blthnenweihfestspiel. Also, this husbanding of the summary Wagnerian work was sought for financial reasons. Chamberlain wrote Cosima that "In spite of all laws and legal books, in spite of the many famous legal experts and juridical congresses, in spite 
Wagnerism, published an attack on Chamberlain in $1900 .^{53}$ Thode praised the Foundations, but noted it really was simply an extension of Wagnerian ideas. Chamberlain took up the challenge, and in his new foreward to the 1909 edition of the book replied sharply, denying any "plagiarism," stating Richard Wagner had no copyright on the themes he had used. The peculiar fact was Cosima had not only. read Thode's criticism before it was published, but had suggested various changes in it: it bore her unmistakable authorization. ${ }^{54}$ While both sides did little to continue the public exploration of this issue ${ }^{55}$ their basic positions remained unchanged, even through the 1908-1927 exceedingly close relationship of Chamberlain and Cosima. 56

of Parliament, Senates, endless researches, the Rights of Man and whatever else was associated with such things, the work "des Geistes" is left without right and protection." It was "stoneage men" who performed Parsifal without the Meisterin's permission. Among those so damned were the previously loyal Mottl and Seidl, who assisted in the Metropolitan Opera productions. Chamberlain to Cosima, December 25, 1903, Briefwechsel, pp. 663-664.

53 This appeared in the Literarisches Zentralblatt fur Deutschland, March 10, 1900, cited in Der Bayreuther Kreis, p. 116.

54 Thode and Chamberlain, close members of the Kreis, were competitive personalities anyway, and during this period kept up only the pretenses of tolerance for each other. Thode ceased addressing Chamberlain as "Mein Freund" or "Lieber Freund," in letters in favor of "Sehr geehrter Heer." Chamberlain responded his book was his own creation he would not suffer to be unjustly accused of illegitimate par entage. Field and Schtler discuss this peculiar incident and report it had as well other implications in Chamberlain's social life. Der Bayreuther Kreis, pp. 118-122.

${ }^{55}$ Chamberlain wrote he was not a member or partisan of any distinguishable group: he remained simply an independent writer and critic. Chamberlain to J. F. Lehmann, March 8, 1904, Briefe I, pp. 132-133.

${ }^{56}$ In 1905 Chamberlain wrote Cosima insisting he really was independent of her tutalage. In writing Das Drama Richard Wagners, for example, he had needed to secure plates from her for his publisher, 
Obviously there was truth and falsity on both sides of the argument. It is just as illustrative of Chamberlain's dearth of selfcriticism that he refused to credit his Wagnerian debt as it is revealing that the Wahnfried Kreis was unable to understand how allencompassing their ideology had become. The identification of reality with Geist prevailed in both camps. 57

During the years in Vienna to 1908, Chamberlain wrote under great emotional stress. He was depressed and considered suicide in 1900, and his relationship with Anna deteriorated. She also had a "Nervenlelden" and a rheumatic condition. Domestic quarrels dominated their occasional conversations in Vienna. She took frequent trips to Kurs while Chamberlain remained absorbed in his Vienna writing and social activities, and in January of 1905 she was advised by her doctors to leave Vienna for an extended rest. ${ }^{58}$ He took this opportunity to ask for a separation, and--after a prolonged series of legal negotiationssecured a divorce in December, 1908. Characteristically, in 1905 he wrote her, "I have the apprehension of another crisis: now or never. I

simply because of the opposition of a cantankerous museum cureator in Munich. Also, with regard to statements he had "studied under your direction," he insisted "I have never at any time studied under your direction. The sources for my works are sources which any other person may use." Chamberlain to Cosima, January 13, 1905, Briefwechsel, p. 681 .

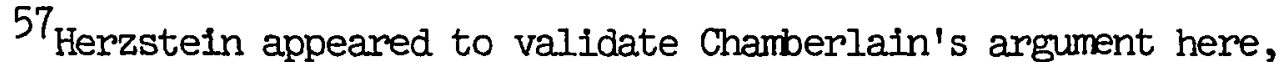
stating that only about one-fifth of Chamberlain's writings were concerned with Richard Wagner. However, Herzstein gives no elaboration as to how he measured this literature, and even if this was the case as regards publications Chamberlain explicitly identified with the Meister, it does not address the broader issue. The point is how much Wagnerian ideas had to do with Chamberlain's Weltanschauung. Herzstein, "The Wagnerian Ethos in German History, "fh., p. 290.

58 Meine Erinnerungen an Houston Stewart Chamberlain, p. 154. 
will and mist have myself; I must or I will be destroyed." 59 Henceforth, negotiations were carried on by their lawyers, although she followed Chamberlain's literary career with great devotion. In London, for instance, she represented herself as still legally his wife in negotiations for an English translation of the Foundations. After a series of hospitalizations she recovered somewhat, did translation work for German newspapers, briefly flung herself into Munich suffragette causes, and died in 1924, still worshipful of Chamberlain. 60

During this creative period, Chamberlain continued to state his fundamental concern: the regeneration of modern society. For him, the real home of Aryan, German man was simply not of this earth. The significance of this fact was not fully grasped by himself or by most of his readers. While Bayreuth for him was an "emblem of battle" 61 around which the Aryans could muster in the battle for Weltanschauung, it was important to stress the ongoing quest for purer motives, purer aesthetic experience, purer life. The expression of this ultimate mystic vision was the Kingdom of God become the Kingdom of Man. Chamberlain, however, living in the real world of nationalism, "comupted" science, and

$$
{ }^{59} \text { Ibid., p. } 156 .
$$

${ }^{60}$ She secured the first translator of the Foundations, John Lees, and only after Chamberlain himself learned of her role did he become dissatisfied with It and attempt to enlist Lord Redesdale as supervisor for the translation. As well, Chamberlain found Redesdale a useful publicist among important circles in England, which aided his pressing for Redesdale's supervision of the English edition of the book. This fascinating story is developed partially in Colin Holmes, "Houston Stewart Chamberlain in Great Britain," the Wiener Library Bulletin, 24 \#2 (1970): pp. 31-36.

${ }^{61}$ Chamberlain, Richard Wagner, p. 379. 
competing "races" found-as did his friend the Kaiser-fullest reception for his ideas in the extremist groups of his day. It was the Pan Germans, the German Youth Movement and the disaffected v8lkische radicals who best understood the import of his proclamations. Thus it was ironic that while he had a spiritual, affective side which in conception he shared with men of leftist as well as rightist political orientation, socialists as well as "proto-fascists," he remained unable to bring his neo-Kantianism to fulfillment except through the mystic futurism of an extremely determinist Aryan ideology. Contemporary reality was simply uncongenial to his highly personal insistence on pure personality, genius and Geist.

A typical experience he fondly recalled in his memoirs occurred in August, 1904, when he set out mountain climbing in the Swiss Alps and found himself overcome by the majesty of the view, and was inspired to write a book about Goethe. ${ }^{62}$ His three major books, the Foundations, Kant and Goethe, were to form a single unity of conception. His formulation of the Aryan spirit growing and asserting itself again in the modern period was the attempt to shape "Aryan" consciousness both as a contemporary fact and as a future possibility. Underlying this with the Lebenslehre was his oft-stated intuitive "eye": with his scientific training this formed the basis for a revitalizing Weltanschauung.

Chamberlain was deprived of his last strong family link to England with the death of his famous uncle, Field Marshal Sir Neville Chamberlain in 1902. Having not read English newspapers during the 62 This was another "electrifying" experience. Lebenswege, p. 142. 
following two years, he later, in 1904, noted these publications had grown-if possible-more egregious. Particularly, they seemed to be lying about political events, criticising Austrian policy, laying "black on white." They too-briefly surveyed facts, a circumstance he declared was not possible in the German-speaking world. ${ }^{63}$ And during this period, deprived of his marriage partner of twenty-five years, himself being fourty-seven years old, Chamberlain appears to have indulged in an exemplary proof of man's foibles: a spate of love affirs. ${ }^{64}$ Field reported Chamberlain threw himself into several liasons which were the subject of later legal proceedings, and of careful scrutiny by Wahnfried. However, he was, as he explained to Cosima, merely indulging in a last "Venusberg" fling of passion; on December 26, 1908, he married Eva, "the daughter des Meisters aller Meister" 65 and moved to Bayreuth. Contemporaries noted how satisfying Chamberlain's final move into the very household of the Kreis appeared. He seemed almost docile in the company of Eva and Cosima; the evenings were taken up with readings at Wahnfrled and no sign of the intellectual assertiveness of the previous years marred their happiness. ${ }^{66}$ Cosima, herself soon increasingly beset

${ }^{63}$ Chamberlain to Graf Wallis, April 2, 1904, Briefe I, p. 139.

64 "Houston Stewart Chamberlain: Prophet of Bayreuth," pp. 509512 and p. 544. Because of Chamberlain's totalitarian views on culture, society and man, and his unwillingness to be be seen as less than a paragon of Victorian morality, Nietzsche's "Human, All Too Human" would be an apt comment on this period in his life. Exactly this sort of unreflective hubris yet "respectability" was what enraged Nietzsche.

${ }^{65}$ Chamberlain to Eva Wagner, October 15, 1908, Chamberlain Nachlass, quoted in "Houston Stewart Chamberlain; Prophet of Bayreuth," p. 529.

${ }^{66}$ As he wrote to Wilhelm II, at last "my life-ship has glided into friendly waters." Chamberlain to the Kaiser, December 11, 1908, Briefe II, p. 231. 
with periods of senile disorientation, was overjoyed at her daughter's husband. He bought a large house next to Wahnfried in which he had built a large telescope to pursue his astronomical observations, and spent much of his time at Wahnfried itself, a senior member of the Kreis. He maintained the best of relations with the other "inner" members, particularly with Siegfried Wagner, a composer in his own right who at last had been permitted to take over the direction of the Festspiele. 67

Chamberlain continued to produce the quantity of articles which were to be so useful to his War Aims Movement work and to the Nazis. But his creative period was waning, his health becoming an increasing matter of concern. His later books were generally composed of earlier essays, notes and ideas. One book he wanted to write but did not was "Germany in the Twentieth Century." The first chapter would have been an historical overview from the Reformation to the 1860 's. The second would have been concerned with the "inner political condition": the conflict of federalism and the central government, the post-Bismarckian growth of bureaucracy and social ills, the evils of Democracy, Demogogues, "Judensozialismus," and the threat of parliamentary government. The fourth chapter would have concerned international developments, of the hostility of the rest of Europe to Germany, and the seriousness of this challenge to Germany (with the overriding need for concentrated German moral, intellectual and artistic weaponry in the service of the nation). The sixth chapter would have dealt with a

${ }^{67}$ He wrote to WilheIm II that Siegfried's creative efforts were particularly welcome since otherwise the art world was being dominated by Jews. Chamberlain to the Kaiser, December 26, 1909, Briefe II, p. 235. 
comparative study of the press, the stock market, the suffragette movement, the Jews, pornography, etc. And the last chapter would have been titled, significantly, "Die Wiedergeburt." The solution that he prescribed included all Germans becoming Protestants, all Germans worshiping at the shrine of Wagner's art, and all Germans helping to construct "Naturanschauung: im Gefolge Goethes." 68

The thoughts to be contained in this book, however, were well presented in Chamberlain's oeuvre. He, in addition to his publicist work, kept up a great correspondence until his last years, defending Germany. ${ }^{69}$ Praised by the Deutsche Dichter-Geddchtnisstiftung, for example, for his contributions to regenerating German literature, he replied to them warmly in a 1912 letter. He lauded their struggle against undesirable literature, "trash" and pornography, and their support of a pure, strong patriotic literature. He stated the degeneration of contemporary literature would lead the Volk to ruin; it would be a thousand times better if people read nothing at all than the scribblings detested by Chamberlain. But, faced with the existing deluge, Chamberlain believed man might sink under the level even of the animal: he hailed the efforts of this nationalist group to stave of $\mathrm{f}^{\prime}$

${ }^{68}$ Chamberlain to "Graf L," March 8, 1910, Briefe I, pp. 186-192. The identity of Chamberlain's acquaintance was not given. Chamberlain refered to his wish for anonymity and gave no clues as to the person's name. Investigation of this sort of problem would have to utilize the Chamberlain Nachlass.

${ }^{69}$ Some of Chamberlain's pejorative terms were remarkably constructed. For example, he called one critic of Wagnerism an "interesting, but sick, hateful, pin-sticking dialectician,"["diesen interessanten, aber krankhasten Stecknakelspitzendialektiker"]. Chamberlain to Postrat Prezsch, August 30, 1911, Briefe II, p. 198. 
this catastrophe. ${ }^{70}$

Chamberlain was greatly influential as a religious authority, and became important in the German Protestant. movement. He formulated, as mentioned, specific doctrines on the Aryan origin of Christ, as well as adding to the anti-Catholic literature of the day. He used the symbol of "Rome" as the all-encompassing repository of corruption in attacking the wide variety of contemporary challenges to "German" greatness. He characterized the scriptural and legal history of the Roman Church as antithetical to freedom, particularly to his notion of "German freedom." However, he had as well a more general influence on Protestantism: he helped to prepare radical formulations which only reached fulfillment, in post-1933 Germany. ${ }^{71}$

${ }^{70}$ Chamberlain to the editor of the Deutsche Dichter-GedHchtnisStiftung, December 26, 1912, Briefe II, pp. 199-201. Field observed,

Underlying Chamberlain's vague and idealistic Kulturkritik therefore was an apocalyptic vision. He warned of the imminent destruction of European civilization and constantly reiterated that mankind had reached the most critical stage of its history. His anxiety sometimes generated deep pessimism, but not, as with Gobineau, a feeling of hopeless fatalism. A militancy and activism reverberated through Chamberlain's work: the Germans could advance or decline but not stand still ... . [Convinced of the racial struggle underlying life, Chamberlain's]. . . paranoid mode of thought manifested marked syncretic tendencies, subjecting everything to a racial dogma and reducing all opposition to a single monolithic Semitic conspiracy.

"Houston Stewart Chamberlain: Prophet of Bayreuth," pp. 501-502.

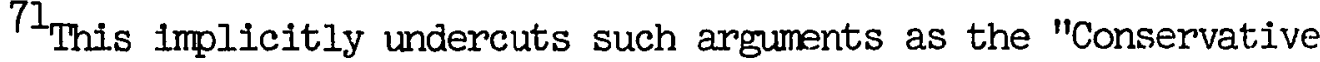
Revolutionary" thesis of Amim Mohler which attempts to isolate radical notions of religion and particularly racism before the interwar period from mainstream German society. Arnim Mohler, Die Konservative Revolution. in Deutschland 1918-1932: Ein Handbuch, 2nd, revised ed. (Darmstadt: Wissenschaftilche Buchgesellschaft, 1972). 
Anti-Semitism was already very wide spread among the populations of German-speaking lands (to say nothing of the rest of Europe, indeed the West in general) before the World War. ${ }^{72}$ Illustrative of this situation before 1914 was the role of Chamberlain himself: he consistently maintained he was not anti-Semitic. He protested his views were based on a correct perception of reality, not prejudice. He wrote he was "a loyal believer in the Church fathers", and that on this account "I hate the anti-Christians." This camp he opposed he said included "Herm Denifle u. comp." 73 as well as the Jews."

Chamberlain sought to maintain links with such eminent theologians as Adolf von Harnack, but found this a difficult task. While he could explain to Cosima Wagner why he minimized his underlying racism for propagandistic purposes and be understood, this tactic did not suceed with a scholar such as Harnack. Chamberlain defended his Goethe to Harnack, maintaining even if it was not entirely accurate, it brought a new world to the view of his readers. He acknowledged various factual errors Harnack had pointed out, but denied he could revise his judgment of the Jews expressed in the book-which were the same as those of his earlier writings. He stated he would not change his views, and cited as evidence his understanding of Kant and the Church Fathers. When

72 "Houston Stewart Chamberlain: Prophet of Bayreuth," p. 464 and Field's "Antisemitism and Weltpolitik," pp. 65-9l.

73 This Catholic scholar's work on Luther was particularly infuriating to many Protestants. HeInrich Joseph Denifle (1844-1905) published, eg., a two volume Luther biography, Luther und Luthertum, im der ersten Entwicklung quellenmassig dargesteIlt (1904-1909).

74 Chamberlain to Hugo Bruckmann, March 29, 1912, Briefe II, p. 207. 
Harnack insisted hatred of the Jews was simply antithetical to true Christlan Love, Chamberlain could only cry he hated Jewry "with all the power" of his souz. 75

While Chamberlain blended the three characterizations of the Jews common to the day's anti-Semites (i.e., of them being revolutionaries, capitalists and liberals) his own practical solutions were vague: he was unsure how to really solve the Jewish "problem." He did, however, jot down many ideas, some of which were later utilized to support Nazi measures. ${ }^{76}$ Anti-Semitism such as Chamberlain's was particularly important in this late Wilhelmine period. Besides pandering to popular taste, it helped the embattled aristocracy persevere in the face of the hated challenges which had become increasingly worrisome since Bismarck's departure: modernism, technology and parliamentarianism. ${ }^{77}$

\section{${ }^{75}$ Chamberlain wrote passionately,}

. . mit allen Kryften meiner Seele hasse ich es und hasse es und hasse es! Und wie dieser Hass aus meiner leidenschaft lichen Liebe entspriesst, ebenso krdyftigt sich und wälchst meine Liebe aus diesem Hass. Gubbe ich einmal den Hass auf, ich bliebe bettelarm an Liebe.

Chamberlain to Harnack, December 9, 1912, Briefe II, p. 218.

${ }^{76}$ Chamberlain suggested many means, from mildly allowing the Jews to voluntarily renounce their religion, to finally limiting their franchise, and even expropriating Jewish property. Particularly the article on the Rumanian Jews was a radical statement. Field discussed Chamberlain's anti-Semitic measures, "Houston Stewart Chamberlairn: Prophet of Bayreuth," p. 441.

77 "Anti-Semitism facilitated the ideological consensus of landed and industrial classes behind a program of conservative modernization." Ibid., p. 461. 
Thus Chamberlain in the years before the World War synthesized his important political and intellectual positions. They were broadcast and only slightly strengthened during the war itself, and they reshaped his reputation outside Germany. After completing his Goethe in 1912 he resumed work on his Lebenslehre and on theology. He hoped to complete the books that ultimately were only published in the Weimar Republic perriod, Mensch und Gott (1.921) and the posthumous Natur und Leben (1928). However, international events were swiftly pressing toward a confroritation between his homeland and his adopted nation. His own loyalty in the face of the coming war was, however, not at question. Chamberlain was in spirit, though not yet in citizenship, Reichsdeutsch. 
CHAPTER VIII

THE TWENTIEIH CENTURY WAR

WORLD WAR ONE

Chamberlain influenced another Wahnfried friend, the India scholar Leopold von Schroeder. While a professor at the University of Viema, and a member of the Imperial Academy of Sciences, Schroeder had delivered a series of lectures during 1910 and 1911. He had linked Wagnerism and imperialism in the Aryan synthesis. He acknowledged that his inspiration on this subject had been Chamberlain, and he continued to speak out on the Bayreuth issues in the coming years. ${ }^{I}$ His Arische Religion and Die Vollendung des arischen Mysteriums in Bayreuth further credited Chamberlain's influence in spreading the Gospel of Wagnerism.2 Schroeder wrote of the genius of Wagner unifying mythic themes and racial heritages for presentation at Bayreuth. He heavily quoted Chamberlain and sought a wide public for himself as well. 3 His was a

IHerzstein, "The Wagnerian Ethos in German History, " p. 277.

2Die Vollendun des arischen Mysteriums in Bayreuth (Munich: J. F. Lehmann, 1911); Arische Religion, 2 vols. (Munich: J. F. Lehmann, 1914-1916.

3Leon Poliakov stated that in spite of the mixture of patriotism and artistic themes, Schroeder's books did not become popular before the World War. There was, Interestingly, a rebuke to Schroeder from Chamberlain, who wrote Schroeder that it was not wise to have alluded favorably to Jewish mysticism in his book des arischen Mysteriums. For Chamberlain, praise such as this had to be considered carefully; it was permissible only in private, since in public it could betray the Aryan 
spectacular synthesis of Aryan mythology, portraying Bayreuth as the Grail repository, the center of Aryan inner strength, demonstrated in the Festspielen. ${ }^{4}$ Continuing his close relationship with Bayreuth, in 1914 Schroeder wrote in the Bayreuther B1 Htter, "Yes, we Germans must strongly realize that our Volk leads in music before all others in the world. ${ }^{5}$

By the era of World War, the Bayeruth Idea thus was well established in German society. ${ }^{6}$ In 1909 the Richard Wagner League of German Women had been founded, and was to persevere through the difficult war years. ${ }^{7}$ In 1912 its chairwoman delivered an address in which she stated, "Germanness was the foundation of Wagner's being, art and life, the source of his works, the source of Bayreuth." 8 Thus, much of Germany's youth was taken up by the Wagner ideology. This third generation, or "v8lkische Jugend" group of Wagnerites, was closely identified with notions of radical nationalism. They had most in common with their grandfathers of the first Wagner generation, rather

cause. Letter, Chamberlain to Schroeder, December 26, 1907, Briefe I, pp. 169-170, quoted in Leon Poliakov, The Aryan Myth: A History of Racist And Nationalist Ideas In Europe, trans. Edmund Howard (New York: Basic Books, Inc., Publishers, 1974), p. 313.

${ }^{4}$ Der Bayreuther Kreis, p. 61. ${ }^{5}$ Ibid., p. 200.

6 In the pre-war period, the interest in a German "artwork of the future" went well beyond simply Wagnerian terms. It was characteristic as well of the Youth Movement, and of many very centrist groups. An example which was attractive to the Nazis for its natural setting and its potential for cultic ritual was at Zoppot in East Prussia. Termed the "Bayreuth of the North," from 1909 Zoppot staged the Meister's works. George L. Mosse, The Nationalization of the Masses: Political Symbolism and Mass Movements In Germany from the Napoleonic Wars Through the ThIrd Relch (New York: Howard Fertig, 1975), p. 112.

7 Der Bayreuther Kreis, p. 61. 8 Margarete Strauss, Richard Wagners Deutschtum (Magdeburg: 1912), 
then their more restrained, or, at least, more "establishment" fathers. Just as the wide Kreis of the first generation was heavily represented with "dilletantische Schw/̈rmer," so was this generation. 9 Sharing in the radicalization of the complex German Youth Movement, Wagnerites. were as well quite prominent in higher education. Though the v8likische Youth Movement was represented by many ideologies, from Zionist, to revolutionary to purely artistic, the German Wagner enthusiasts were characteristically proto-Nazi. Indeed, some of their number became leaders in the Third Reich. Kurt von Westernhagen, for exarmle, was a young member of the Berlin Academic Wagnerverein, a fervent National Socialist, and a leader of the Hitler Jugend. A doctor, he survived World War Two and continued to publish quite extreme Wagnerite literature in Switzerland. ${ }^{10}$ otto Daube (b. 1900) was influential in his Bayreuther Bund der Deutschen Jugend. He wrote the book, Mythos der Frontgeneration. Many writers such as Paul Blllow and Oskar Doring, were young men during the First World War. In 1916, for example, the young Guthter Holstein (1892-1931), later a law professor, wrote to Wolzogen how enthusiastically he agreed that the inner regeneration of the Volk would fuse Christianity and Deutschtum through the example of the great Wagnerian Vorkdmpfer. He was referring to the Meister and Meisterin and the inner Kreis. ${ }^{\text {Il }}$ Karl Richard Ganzer (1909-1943) published a standard Nazi interpretation of the Meister. ${ }^{12}$ He worked

address delivered in Magdeburg before the League of German Women, Pansa 1912; cited in Herzstein, "The Wagnerian Ethos in German History," p. 251.

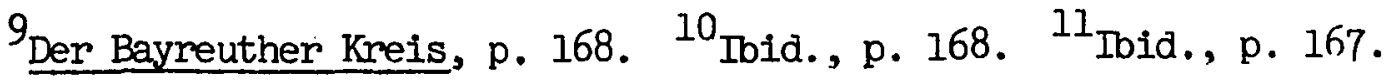
${ }^{12}$ Karl Richard Ganzer, Richard Wagner der Revolutiondr gegen das 19. Jahrhundert (Munich: 1934). 
with Walther Frank and the Reichsinstitut for the history of the new, Nazi, Germany. His Wagner essay praised a struggle by the Meister against the Jewish, liberalistic nineteenth century. ${ }^{13}$

This third generation, twentieth century Wagnerism, ended only with the apocalypse of 1945 . Its formative period was the era of World War One, when nearly all Germans believed struggle was necessary, even preferable to suffering second-rate international status. The expression of this desire for world power had begun in the late 1890's with the construction of Tirpitz' High Seas Battle Fleet. Though successive increases in military and technological effort had indeed greatly enhanced Germany's position as a world power, many Germans still felt British international dominance obstructed their destiny's path. The convoluted German policies of the day were closely associated with a series of war scares. Repeatedly the major powers came close to war, particularly in the 1905-1906 First Morocco Crisis, the 1911 Second Morocco Crisis, and during the 1912 and 1913 Balkan Crisis. ${ }^{14}$ The stresses of the day were immense, seemingly pressing toward only a military confrontation. For governments such as that of Wilhelmine Germany, the choice was increasingly whether a war or a domestic revolution should be dared: war was the less-feared option.

During the war scare of 1912 Chamberlain had written to the Kaiser

${ }^{13}$ Cited in Herzstein, "The Wagnerian Ethos in German History," pp. 358-359.

14 The standard English text for general German history is Hajo Holborn, A History of Modern Germany, vol. 3: 1840-1945 (New York: Alfred A. Knopf, 1969): 1905-1906 First Morocco Crisis, pp. 327-328; 1908-1909 Bosnia Crisis, pp. 329-330; 1911 Second Morocco Crisis, pp. 337-338; and 1912-1913 Balkan Wars, pp, 340-341. More specialized is 
that the times demanded every heart choose which nation it must support: England or Germany. He thus felt honored to be able to write to Wilhelm II, the "helmsman" of his adopted country. He was happy to report to the Kaiser that he had received an enthusiastic letter from a young officer who expressed boundless confidence in the Kaiser's leadership, and jubilantly anticipated "der Tag" when the name of Wilhelm II and of Germany would be properly known and honored throughout the entire world. Chamberlain assured the Kaiser that recent remarks made by a member of the Reichstag to the effect that Wilhelm was throwing dynamite in the air without looking where it might land were without foundation. Chamberlain said he himself was a patriotic Englishman, but believed England should recognize that the German fleet was intended not to compete with, but to co-operate with England. 15

In 1913, Chamberlain relayed the best wishes of Lord Redesdale, the English translator of his Foundations and Kant to the Kaiser. This Englishman, Chamberlain wrote, was at the time an approving observer of the Kaiser's "youthful policies." Chamberlain expressed the hope this assurance from an influential Fnglish aristocrat would clear up some of the then-current "malevolent 'German Ocean' fog."16 Lord Redesdale later, in January, 1914, wrote an extremely pro-Chamberlain article for

Fritz Fischer, Germany's Aims In The First World War (New York: W. W. Norton \& Company, 1967).

${ }^{15}$ Chamberlain to the Kaiser, January I, 1912, Briefe II, p. 239. ${ }^{16}$ Chamberlain to the Kaiser, December 18, 1913, Briefe II, p. 242. Chamberlain further assured Wilhelm that current German and English criticism was merely the work of Jews and the press. Chamberlain to the Kaiser, January 21, 1914, Briefe II, p. 243. 
the Edinburgh Review, in which he praised the publishing activities of the Wahnfried disciple, chiding only Chamberlain's racism. Redesdale believed that had Chamberlain lived around the "most distinguished Jews" such as were to be found in the English upper class, he would have changed his opinion of these people. As it was, Redesdale believed Chamberlain had taken for a model merely the "low Polish Jew, whom we see in the sweated tailor of the East End." ${ }^{17}$ Redesdale even at this late date in the animosity of Germany and England stated his approval of Chamberlain's Aryan since the world that species had entered "was an Augean Stable; its cleansing, the work of a Hercules." Further, Redesdale hoped a translator would be found for Chamberlain's recent Goethe, a "inasterpiece drawn, to use an expression of Goethe's own, 'from the depths of humanity. $" 18$

Such literary activities did not, however, prevent the outbreak of World War in August, 1914. Chamberlain had long dreaded this development; he had hoped his choice would not have to be between Germany and the "verbundeten RHuberv"lker." 19 It placed him in an emotional crucible. He feared the war of his former, "materialistic" homeland against his idealized adopted country. This was a great hardship for the sensitive aesthete, who wrote he would have preferred death to witnessing the launching of war on Germany by England. ${ }^{20}$ His

${ }^{17}$ Lord Redesdale, "Houston Stewart Chamberlain's Foundations of the Nineteenth Century," Edinburgh Review, vol. 219 (January, 1914), p. 81 .

${ }^{18}$ Ibid., pp. 83-90.

${ }^{19}$ Lebenswege, p. 153.

${ }^{20}$ Chamberlain to Justizrat Troll, Briefe I, p. 231. 
decision to aid Germany was made quite soon after the outbreak of war, but with great pain. After Germany he still loved England best, and he did not immediately seek to change his citizenship.

The late summer of 1914 was a time of physiological as well as psychological stress for the erstwhile Englishman. He suffered a relapse of his long-standing disease, and became progressively stricken with a painful paralysis of his limbs. Despite his illness, from which he was freed only by death thirteen years later, Chamberlain began writing for the German cause. ${ }^{21}$ He wrote a great number of essays, the Kriegsaufsutze, which were collected and republished in cheap trench editions in 1914, 1915 and 1916, as well as a number of other booklets. Chamberlain also kept up a great correspondence during this time, with not simply his usual select aristocratic and literary friends, but with military men of all ranks, and with young students and bereaved parents. He carried on editorial duties which later represented the goals of the annexationist War Aims Movement, and he continued to read, research and prepare material for his postwar books. This truly remarkable labor was probably one reason for the worsening of his physical condition. By war's end he was virtually crippled. Schller noted this effort was perhaps comparable to that dramatic suffering endured by Wagner's operatic characters striving toward regeneration. ${ }^{22}$

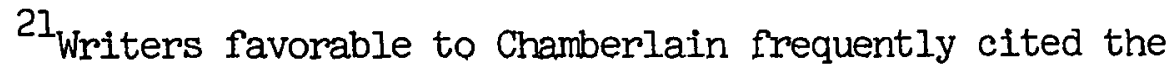
combination of events surrounding the outbreak of World War One as being a particularly destructive series of events for the author. For whatever reasons, the political events did coincide with a breakdown in his own health as cited, for example, in Doring, Ein Deutscher namens ChamberIain, p. 33.

22 Der Bayreuther Kreis, p. 266. 
Soon after the outbreak of war, Chamberlain was prodded by friends such as Jacob Uexkllil to write articles against the Entente. Chamberlain believed the English were indeed "die Lllge," who were not yet ready to hear the truth. First they needed to experience "vernichtende Schlldge"; then they would be ready to understand how far they were from the righteous Germans. He closed a letter with a statement he often made during the war, "How this affects the inner self you can only imagine." 23 Chamberlain could sleep only fitfully since the beginning of war, and he sought distraction gazing at the stars through his telescope. But even this pastime aroused the curiosity of his German neighbors, since some thought he might be an English agent. Nevertheless, when a French airplane was thought headed for Bayreuth, Chamberlain was proud to note the homeguard asked him to look out for it with his telescope. 24

The rumor he was a spy infuriated the author. Perhaps his domestic enemies utilized this occasion to ensnare him in a succession of bureaucratic difficulties. He was unwilling to immediately apply for German citizenship, and noted that consequently he was accosted by an officer from Nuremberg. ${ }^{25}$ However, soon he realized the war would not end Immediately, and complained at the bureaucracy's slowness in processing his citizenship papers. During the early period of the war he was so sensitive to criticism he abandoned going into the town of

${ }^{23}$ Chamberlain to Uexkll1, August 23, 1914, Briefe I, p. 235. 24 Lebenswejge, p. 154. ${ }^{25}$ Chamberlain to Uexkllil, AUgust 23, 1914, Briefe I, p. 237. 
Bayreuth for fear he would be asked if he secretly radioed information to the Entente. 26

Chamberlain believed the pre-war years had seen the English press prepare for the present conflict. He said the newspapers and journals had talked of nothing but hate for Germany and the inevitability of war. They had systematically disseminated this poison. But he recalled fondly Victorian England, before the rule of Edward VII (1901-1910). He claimed to have observed a particularly galling "rawness" displayed in the behavior of Englishmen, on English streets, and among even the young members of the English aristocracy. He reread Burke's "Impeachment of Warren Hastings" as an illustration of the degredation possible in a parliamentary system. But in contemporary Germany, Chamberlain was convinced no such Anglo-Saxon perversion would be possible: "Deutschland Uber alles, ob siegend oder besiegt! "27

In the euphoria of the early war, the "mood of August, 1914," so pronounded in Entente as well as Central Power nations, Chamberlain even permitted himself some pride in the behavior of Germany's Reichstag. He noted the Kameradschaft so visible among the rulers and the people, the officers and soldiers of the Reich, even among the delegates to the Reichstag, united as they had been in voting war credits. ${ }^{28}$ Sharing the high expectations of most Germans during the early months of war, he

${ }^{26}$ Ibid., p. 239.

27 Chamberlain to Count Carl Pllckler, September 18, 1914, Brief'e I, pp. 245-246.

${ }^{28}$ Chamberlain to Prince Max von Baden, September 22, 1914, Briefe I, pp. 248-249. 
believed the English would soon experience the crushing defeat of France in 1870; soon England would then be ready for tutelage by a dominant Germany. 29

Chamberlain's first war essays "by the heart-broken, but grimly determined 'Englander, ' Houston Stewart Chamberlain." 30 He found them popular in Germany, particularly among the ruling councils of the Reich. In November, 1914, Wilhelm II sent him a telegram from his residence at the Supreme Headquarters stating he had read a recent Chamberlain article "with pounding heart and elevated soul," and had found it "meisterhaft." 31 These essays were collected as the first volume of Kriegsaufsatze in 1914, and Chamberlain continued to publish articles which considered not merely the circumstances of the war's outbreak, but increasingly emphasized the cultural-philosophical justifications for German's entire war effort. Some of the programatic titles were "Deutschland als fllhrender Weltstaat," "Die deutsche Sprache," "Deutsche Friedensliebe," and "Englische Geleherte." 32 These essays were generally well received in Germany, as it was felt Chamberlain's international reputation would be effective in the battle to enlist neutral sympathy for Germany. Toward that end, in 1915 a booklet, "Who is to blame for the War," was published in English in Stockholm. In it, ${ }^{29}$ Ibid., p. 250.

30 Reproduced in Briefe I, p. 244.

${ }^{3 I_{W}}$ Ihelm II telegram to Chamberlain, November 25, 1914, Briefe II, p. 244.

32 The best bibliography of Chamberlain publications is Field's, "Houston Stewart Chamberlain: Prophet of Bayreuth," listed on p. 565. 
Chamberlain repeated the German nationalist claim that Germany was the victim of a horrible conspiracy, and he utilized arguments now rather difficult to understand. Perhaps he believed he was speaking to people as sympathetic to him as were his German friends; his arguements were, in any case, hardly likely to influence readers not already pro-German. He stated that Germany simply could not have entered into an unjustified war. This was becauses in Germany a "tribunal of princes" advised the Kaiser in the confederation form of government; deliberation and education in the best traditions therefore guided the Kaiser as Supreme War Lord. Further, to illustarate the contrast of this policy with that of his homeland, Chamberlain stated the English could be easily guided along nefarious paths simply by the machinations of parliamentary ministers. 33 In England he was soon called a renegade.

The war cut off his main non-German source of funds, his bequests from a series of recently-deceased family members. 34 This meant a real. decline in his living standard, since he and the Wagners were not personally wealthy. The war also reduced the dividends and royalties from his continental interests and his book sales. But the arrangement he made with Bruckmann to print massive quantities of his essays in popular editions at least kept the Chamberlain household financially

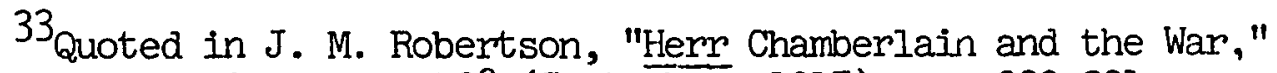
Contemporary Review, vol. 108 (September, 1915), pp. 299-301.

34 Field gave an appendix on Chamberlain's finances which showed Chamberlain had in fact been more wealthy than anyone had imagined at the time. It is inferred his family may have acted swiftly to protect some of his holdings in. England at the outbreak of war in 1914. "Houston Stewart Chamberlain: Prophet of Bayreuth," pp. 534-551. 
solvent. Chamberlain insisted he himself did not make money from these books, rather he donated monies to an organization he believed capable of distributing "charity" wisely, the German Army. 35 His publisher, Bruckmann, however, did profit greatly by this work, which was the source of later recriminations. 36

In the fall of 1914, after months of inquiry and work by his lawyers, Chamberlain found that he had been kept under military observation because he had indeed been denounced as a spy. He wrote, characteristically, this was the work of "eine Dame hebrlischer Konfession." 37 This, with the knowledge he had the use of a powerful

${ }^{35}$ Chamberlain to Brockdorff-Rantzau, September 23, 1914, Briefe II, p. 255. He explained that he and Eva had agreed to secretly donate the proceeds to the army because the Red Cross simply did not cover all cases of need. As well, he preferred to deal with individuals, and thought the best managers in this situation would be the military authorities. Chamberlain to Major General Hagen, December 30, 1914, Briefe II, p. 275.

36 There were also other problems for Wahnfried in 1914. Finally the family jealousies of decades came to public view in a sensational trial held to determine the inheritance of the Wagner's eldest child, Daniela. At issue was whether she was the child of Blllow or of Wagner. Cosima had insisted she was Blliow's child, but this was not accepted by Daniela. Though the Bayreuth performances themselves were cancelled with the outbreak of war, and though Bayreuth would not reopen until 1924, the issue was whether Daniela was entitled to participate in the management of the Festspiele. The result of the trial was quite messy, but indecisive. Cosima's testimony she had been faithful to her husband Blliow in the summer of 1864 was refuted by a surprise witness, the housekeeper from those Munich days, Anna Mrazek, who told the court how Cosima had been shared by the two musicians. Chamberlain and his wife Eva (Daniela's sister) evidently were significant in helping Cosima prosecute this matter, which was altogether highly embarrasing for Wahnfried. Gutman, Richard Wagner: The Man, His Mind, and His Music, p. 235. pp. 252-253.

${ }^{37}$ Chamberlain to Brockdorff-Rantzau, September 23, 1914, Briefe I, 
telescope, had been sufficient to raise the authorities' interest. Apparently the entire problem of his national status became involved here; for financial as well as patriotic reasons Chamberlain applied for naturalization. He explained that the local official who had to rule on such cases before they could be passed on to the government in Munich was a certain Oberbügermeister Dr. Taffelmann, a well-known Bayreuth National Liberal leader. Accordingly, this added to the problems faced because of his enemies and because of his quite English name. He believed it would have been easier for him to gain citizenship as a Jew than as a perfectly "genuine" Aryan. 38

Late in 1914, he received a letter from his brother Basil informing him that in England he was being called a name beginning with the letter " $R$ " for renegade. 39 In his reply Houston asked Basil to forward English magazines and newspapers to him and also appealed for his brother to understand, even if he would not agree, with his politics. He recalled how Basil had helped him in publishing and in criticising his manuscripts, and was sure that because of Basil's deep culture and fine education, he would understand how Hobbe's maxim "insuperable might is right" had become true for their homeland, England. He appealed as well to Basil as a fellow writer to understand how terrible it was to have only the writing table as a weapon against "ein verdammes zivilistisches Kunstprodukt" such as the Entente. ${ }^{40}$ Houston also made a 38 Ibid., p. 254. 39 Houston to Basil Chamberlain, October 30, 1914, Briefe I, p. 261. ${ }^{40}$ Ibid., p. 261. 
claim which must be understood in the context of his own intense desire to solicit his brother's support: he claimed to have secret information about European politics which went well beyond that available to the mere newspaper reader. Whether Basil belleved this, or if Houston himself did, it does not appear Houston was successful in persuading non-German sympathizers that he spoke with the authority of the government. 41

The first mention of less-confident expectations for the war's speedy conclusion was in a letter Chamberlain sent to Ieopold von Schroeder in November, 1914. Chamberlain was again taking daily walks in Bayreuth, and he now noted that the labor situation had been disrupted. For the fall harvest there were fewer young male workers, and in the towns there were only soldiers. He noted the serving man at Wahnfried now was certainly no "cavalier," rather he was a forty-two year old man unfit for military duty. Chamberlain related he had seen his first wounded men, that there were more arriving all the time, and that now the military age had been extended to include middle aged men. ${ }^{42}$

${ }^{4} I_{\text {This }}$ curious statement was,

Ich besass schon frither Beziehungen zu Fillisten und zu einzelnen Diplomaten, dank welchen ich doch manches richtiger erblickte als der gewb̆hnliche Zeitungsleser; seit meinem Eintritt in die Wahnfrieder Familie sind aber diese Beziehungen noch zahlreicher. geworden; man weiss eigentlich spottwenig von der Politik Europas, wenn man nicht eigentlich ein wenig hinter die Kulissen (arras) zu schauen vermag.

Perhaps this should be considered as well in the light of his aesthetic ortentation and his closeness to publicist and chauvinist groups: he intensely desired to convince his brother Germany was correct. Houston to Basil Chamberlain, October 30, 1914, Briefe I, p. 263.

${ }^{42}$ Chamberlain to Schroeder, November 1, 1914, Briefe I, p. 266. Later in November he noted the widening trench and submarine warfare, 
CHAMBERLAIN AND THE WAR ATMS MOVEMENT

The much-remarked unity of August, 1914, ha: been the result of many complex factors in Germany. In particular, the technological position of Germany as a world trading power was perceived to be second only to that of Great Britain. Germany had a burgeoning population, having gained thirty millions since 1871. Most importantly, the creaking machinery of the Second Empire's parliamentary government was challenged from within by the largest party, the Socialists. The unity, the sense of relief at having overcome internal divisiveness visible in August, 1914, was a commodity purchased at the price of an eminent German military victory. Only then would it have been possible to satisfy the conflicting interests in the Empire and yet keep the power structure intact. When this victory receded into the realm of first improbability, then impossibility, increasing segments of German society questioned the government's leadership. With very few exceptions, 43 Germans were disillusioned not by the competing German imperialistic motives; but by the simple failure to win a battlefield victory and to maintain domestic conditions at the pre-war levels of sustenance. In

and expressed his often-stated desire to be at the front, with the "German heroes," where he could sacrifice his life. Chamberlain to Adolph Appia, November 4, 1914, Briefe I, p. 269.

43 The main exception was the Socialists. A small group broke first with the party's leadership, formed an independent group, and finally split again, later founding the early German Commist Party. The definitive English history of this is Carl E. Schorske, German Social Democracy 1905-1907: The Development of the Great Schism (New York: Harper \& Row, Publishers, 1972). 
this situation, the first, tentative peace feelers sent out by Germany in Novemberj 1914, were discovered by the rest of the nation. Rumors of the peace conditions asked and offered were discussed, and it was popularly feared that the Chancellor, Bethmann-Hollweg, diplomats, businessmen, particularly Jews, wanted "to conclude a 'cheap' or 'rotten' peace. $" 44$

Thus, the entire problem of the Second Empire's internal divisiveness came to the fore in the first winter of war. England was a symbol of modemity, the example for world-wide corruption, which Germany might follow if drastic measures were not taken. The war itself was seen as a measure ensuring Germany's salvation--except the war had therefore to be victorious to prevent the destruction of the power of the monarchy, the aristocracy, and commercial and industrial groups. In this situation in the winter of 1914-1915, it became increasingly necessary for Germany to find broader reasons, more basic values which justified the entire war effort. Disseminating such views would help prevent worker rebellions-important since now most of the German army was fighting beyond the Reich's borders, not quartered at home to protect the government. Statements were made calling for the annexation of large areas of eastern and western Europe by important men and groups in Germany. The government, as a consequence, found it necessary to attempt to ban the public discussion of war aims; otherwise the nation would be deprived of diplomatic flexibility. Important groups of industrialists, the Pan Germans and argrarian interests were increasingly

44 Fritz Fischer, Germany's Aims In The First World War (New York: W. W. Norton \& Company, Inc., 1961), pp. 164-165. 
dissatisfied with the civilian government's leadership. Instead, they found to their liking the formidable military heroes, generals Paul von Hindenburg (1847-1934) and Erich Ludendorff (1865-1937).

Though Chamberlain was increasingly ill during this time, he asked his correspondents to ascertain the extent of Reichstag opposition to the war. ${ }^{45}$ Confined mainly to Bayreuth, he was informed on the essentials of political news at least during the first half of the war. 46 Chamberlain was in contact with annexationist writers. ${ }^{47}$ He was encouraged in writing for the German cause as well by foreign businessmen and came to believe his own publishing efforts were more successful at influencing neutrals than were some of the German "Aufklyrungskomitees" and even some of the diplomatic service. ${ }^{48}$

${ }^{45}$ He was laid up in bed for four weeks during December and January. Chamberlain to Bllrgermeister Bleicker, January 4, 1915, Briefe I, p.276. 46 Anticipating the nationalist interest in military leadership, he also inveighed against the day's politicians and the absence of "grosse Persbnlichkeiten" in Germany's hour of need. Ibid, p. 277.

${ }^{47}$ He thanked a Dr. Helmolt, who had sent him a copy of his Die geheime Vorgeschichte des Weltkrieges. Chamberlain to Dr. Helmolt, January 7, 1915, Briefe I, p.278. Chamberlain to Bruckmann, February 11, 1915, Briefe I, pp. 279280. He believed that especially in the Low Countries his writings were well received. He was assured by a Dutchman, Herr Landwirth, that his Kriegsaufsutze had made a deep and clear impression. Further, Senator Beveridge from Washington D. C. visited Wahnfried and told Chamberlain that his.Foundations made a great impression among a small but growing, circle of important men in the U. S. A. This, Chamberlain said, was significantly better than the efforts of the German diplomatic missions which frequently made mistakes demonstrating their inability to comprehend reality: "Diese Ieute haben keine Nase, keine Witterung." Chamberlain had found his contemporary heroes: "Gott segne Hindenburg und Ludendorff." Chamberlain to Bruckmann, February 17, Briefe I, p. 282. 
Writing to Prince Max of Baden, Chamberlain noted the disaffection among Germany's Socialists, and repeated the standard rebuke: "Steril ist nur der Geist der stets verneint." Further, he compared the socialists' "eternal nay-saying" to his hated "liberale Bulrgerschaft." 49 But Chamberlain had difficulties with censors in Germany because of his articles' inflammatory tone and their titles. ${ }^{50}$ Further, he complained that the Foreign Office took offense at his articles released in England and America, and asked if this might have been due to the narrow-mindedness of Berlin functionaries and the Jewish influence in general. 51

Chamberlain found himself in the company of a great many likeminded men and interest groups in Germany. He worked in the War Aims Movement, that most annexationist collection of interests who supported Hindenburg and Ludendorff, and over the course of the war became increasingly strident. In 1917 the War Aims Movement founded a journal which continued well into the Nazi era. The title of this perindical

${ }^{49}$ He told the diplomat how he kept a portrait of the Kaiser and Hindenburg in his dressing room so that he might see them and take heart at least twice a day. Chamberlain to Max of Baden, February 21, 1915, Briefe I, p. 285.

\footnotetext{
p. 288.

${ }^{50}$ Chamberlain to Alfred von Bary, February 25, 1915, Briefe I,
}

${ }^{51}$ Chamberlain to Max of Baden, March 19, 1915, Briefe I, p. 291. He, of course, brooked no disagreement with his own views, terming a Swiss who disagreed with him a "Schweinehund." His characteristic closing line was, "Wer nicht mit mir ist, ist wider mich." Chamberlain to Bruckmann, February $25,19 \overline{15}$, Briefe I, p. 291. Chamberlain related that friends had told him he was hated by the Jews, and this appeared to be so whether they were full Jews or Mischlinge. He found additional proof for this in criticisms made of his reprinted works during the war. Chamberlain to Major von Kotze, April 3, 1915, Briefe I, p. 308. 
indicated their interests: Deutschlands Erneuerung. But Chamberlain had been part of this movement from the first winter of the war. In 1915 he published another large number of essays. They included "Bismarck der Deutsche," "Freiheit," "England und Deutschland," "Martin Luther," and "Des Weltkrieges letzte Phase." He also published three collections of essays in book form, the second edition of the war essays, Neue Kriegsaufsätze, Wer hat der Krieg verschuldet? (mentioned in this chapter in its English translation) and Politische Ideale. ${ }^{52}$

The last-mentioned book found special favor with nationalists through the Nazi period. In it Chamberlain looked forward to an organization of the German people which came near to realization only in the last year of total war effort. It clearly anticipated the modern reforms of the Third Reich:

. . Once Germany has achieved power and we may confidently expect her to achieve it-she must immediately begin to carry out a scientific polity of genius. Augustus undertook a systematic transformation of the world, and Germany must do the same . . . Equipped with offensive and defensive weapons, organized as firmly and flawlessly as the Army, superior to all in art, science, technology, industry, commerce, finance, in every field, in short; teacher, helmsman, and pioneer of the world, every man at his post, every man giving his utmost for the holy cause--thus Germany, emanating efficiency, will conquer the world by inner superiority. 53

For Chamberlain this would be the result of combining pre-existing and quite new elements:

52"Houston Stewart Chamberlain: Prophet of Bayreuth." p. 553 and pp. 565-566.

${ }^{53}$ Quoted in Konrad Heiden, Der Fthhrer (Boston: Beacon Press, 1965), p. 239, and "Houston Stewart Chamberlain: Prophet of Bayreuth," p. 506 . 
- . The monarchy represents the age old German heritage; what is new-rising in our midst but an unconscious process--is a second political principle of the German future; the indubitable mission of Germany to organize all political life scientifically - . By 'scientific organisation' I mean application of those scientific principles which have led in Germany to such unprecedented results in the fields of technology, research, and to a great extent, in administration as well; furthermore, I include the most meticulous precision in directing the available means toward the aims to be achieved, and the application of forces in such a way as to obtain the maxinium results with a minimum expenditure, thus multiplying the forces at out disposal a hundredfold; besides, division of labor, whereby every man does the work he understands and for which he is suited by nature-all this presupposes practical systematization; that is to say, planned co-ordination of all the parts of every productive unit.54

Chamberlain was thus one of many prominent spokesmen for the extreme nationalists. In recognition of his publishing work he was awarded the Iron Cross with the white ribbon of the non-combatant on his sixtieth birthday, April 24, 1915.55 Though he continued to struggle with his illness, he kept up a massive correspondence throughout the war's early years. 56 He kept up with such current developments as the 1915 sinking of the Lusitania, but he retained his own particular stabin-the-back interpretation. He believed that the ineffective Geman

54 Ibid., p. 504 .

$55_{\text {Though technically the War Aims Movement and its journal }}$ Deutschlands Erneurung did not begin publication until 1917, this generic term was applied to the publicist efforts of extreme nationalists after 1914. Thus Chamberlain's medal was awarded for this effort in addition to his many popularly-priced republications for the troops. Michael D. Biddiss, "Houston Stewart Chamberlain: Prophet of Teutonism," History Today, 19 (January, 1969), p. 17. He was acclaimed by the Kaiser as "the most important thinker since Kant and Schopenhauer." Louis L. Snyder, German Nationalism: The Tragedy of a People (Port Washington, New York: Kennikat Press, 1969), p, 211.

${ }^{56} \mathrm{He}$ stated that only the urgency of his labors got him out of his sick bed. Chamberlain to Westermanns Monatsheften, May 19, 1915, Briefe I. p. 313 . 
responses to the sinking of the Lusitania were due to there being great numbers of "elégants" among German diplomats, as many of these men had foreign-born wives. This situation he contrasted with the pristine military leadership given by Hindenburg and Ludendorff. 57 While Chamberlain could take heart at the extremism of the Intellectual's Petition of 1915,58 he feared the counter-development of more moderate groups; his own mentality had been prepared for the war-time conspiratorial theorizing which came to fulfillment in the years of World War.

Bayreuth was a continuing symbol of hope and sustenance in the German war effort. Siegfried Wagner as well as Chamberlain kept up a great patriotic correspondence. But the prominence of Wahnfried had brought another development which the reclusive, aristocratic author found perhaps less exciting. Now that his war essays, not his earlier cultural-historical works had made his name known, many people came to visit. Many soldiers came to Bayeruth to see him, many adherents of Wagnerism, editors, writers, and many "Philister" as well who sought to get or to give advice. But Chamberlain endured this busy. environment and the increasing pain in his left arm, and saved his ire for Germany's internal "enemies". These he despised above all others: the "Ledebours

${ }^{57}$ Chamberlain to Prof. J. Kohler, June 6, 1915, Briefe I, p. 314.

58 The Inteilectual's Petition, signed by 1347 prominent Germans including 352 professors endorsed the German drive for victory on July 8, 1915. There was as well an Indeperident Commission for a German Peace which also pressed for radical territorial demands. On July 9, 1915, a small group of moderates around professor Hans Delbrllck and Adolf von Harnack signed a petition, but enlisted only 141 names, including 80 professors. Ringer, The Decline of The German Mandarins, pp. 189-190. 
und Liebknechts," the "Liberalen" and the diplomats. 59 He sought to lay aside all internal German problems of parties, religions and aesthetics: all interests should have been subordinated to winning the war. 60 This was, of course, a common technique of the day. Chamberlain covered his very current political interests with the overall maxim of defense for the German people. Such proclamations were the veneer for his very real prescriptions. 61

Chamberlain continued to meet many prominent Germans. Returning from a trip to Frankfurt where electrical treatments for his paralized left arm had been attempted, Chamberlain met Count Zeppelin. Chamberlain later claimed the Count told him about new aircraft and submarine weapons which would soon aid the war effort. 62 Sporadically during the remainder of the war Chamberlain and the Kaiser continued their correspondence, which was usually hand-delivered by special courier.

${ }^{59}$ Chamberlain to Frdulein Sidonie Peter, August 1, 1915, Briefe I, pp. 318-319.

${ }^{60}$ Chamberlain to the editor of Der Deutschen Gesellschaft fur Bev8lkerungspolitik, October 18, 1915, Briefe I, p. 327.

${ }^{61}$ Chamberlain got into legal troubles during the war period. He was defended by the Pan German Heinrich Class in a suit for racist Iibel. Mosse, The Crisis of German Ideology, p. 222. The attitudes of the Bayreuth Krels were, naturally enough, contested by many former adherents outside Germany. In 1915 the former friend Ashton Ellis defended the non-political interpretation of Wagner against Bayreuth's Deutschtum synthesis in "Richard Wagner contra Militarism," The Musical Times (1915), cited in Herzstein, "The Wagnerian Ethos in German History," p. 240 .

62 He mentioned this in print in 1920, however, and could have meant it more in terms of the post-war revenge motif than in the sense the Count actually gave him any intelligence data in 1915. Chamberlain foreward to the third edition of his Goethe; in Chamberlain, Drei Vorworte (Munich: Bruckmann, 1920), p. 12 . 
The Kaiser dispatched a note thanking him for his contributions after each new Chamberlain publication. He confided to Chamberlain that Lloyd George and Briand had "no Idea of the powerful service you have performed for me and for the German people." 63

Difficulties continued for Chamberlain's articles, some beinf rejected by censors because of their annexationist tone, and some being discussed in the Reichstag. ${ }^{64}$ He was confined to bed for three months in the spring of 1916, during which time his doctors discouraged him from writing. ${ }^{65}$ In May, 1916, the Chamberlains moved from their former house in Bayreuth to a house on Wahnfriedstrasse directly across from Wahnfried proper. ${ }^{66}$ This was made possible by the contributions of the wealthy south German businessman and long-time Chamberlain admirer, August Ludowici. However, during the course of the war, the Wagner clan suffered a decline in income due to the inactivity of the Festspielhaus

63 Wilhelm II to Chamberlain, January 15, 1917, Briefe II, pp. 250-251.

${ }^{64}$ Chamberlain to J. F. Lehmann, February 7, 1916, Briefe II, pp. 5-6; also his "Des Weltkrieges letzte Phase" could at first only be printed privately. Chamberlain to General Matthias Hoch, January 23, 1916, Briefe II, p.2.

${ }^{65}$ Chamberlain to Pastor Karl Schneider, July 23, 1916, Briefe II, p. 24. During this time he intriguingly extended his conspiratorial theorizing to include Freemasonry. He remembered in a letter that his brother Henry had been gradually transformed from an upstanding man into an agnostic, then a political radical, and finally into a German-hater, member of the Naval Defense League. But Houston stated he would not corment on whether there was a causal relationship between Freemasoriry and the corruption of his formerly "pristine" brother. Chamberlain to R. Rickners, January 23, 1916, Briefe II, p. 3.

${ }^{66}$ Schroeder, Houston Stewart Chamberlain: Ein Abriss seines Lebens, p. 93. 
and to inflation. Fuel for heating was scarce and so costly that only Cosima's upstairs room at Wahnfried was heated. The rest of the Wagners moved into Siegfried's former bachelor house next to Wahnfried, from which they returned only in 1922. It was reported the lawns and gardens of Wahnfried were even converted to raising cabbage until 1924. 67

In August, 1916, Chamberlain was finally made a naturalized German citizen. This allowed him to fulfill his long-held wish of joining his friend Heinrich Class' Alldeutsche Verband. ${ }^{68}$ In the late summer of 1916 he rested at Bad Gastein under doctor's orders. ${ }^{69}$ While recuperating he exchanged a series of letters with the publisher J. F. Lehmann who was very interested in annexationist matters. The two discussed exactly how they could combat socialism without hurting the war effort by dividing the German people. Lehmann, like Chamberlain, was influential in linking anti-Catholicism and anti-Semitism, and was

67 Friedelind Wagner and Page Cooper, Heritage of Fire: The Story of Richard Wagner's Granddaughter (New York: Harper \& Brothers Publishers, Inc., 1945), intro., p. xi.

${ }^{68}$ Chamberlain to J. F. Lehmann, August 9, 1916, Briefe II, p. 30. However, Chamberlain delayed another long-held intention because of the war. He had agreed with the single-tax ideal of the vblkische writer Adolf Damaschke (Die Bodenreform, 1902), but believed endorsing it before the war was won might prejudice the national effort. Mosse, The Crisis of German Ideology, p. 109.

${ }^{69}$ At Bad Gastein Chamberlain and Leopold von Schroeder met and discussed the day's issues. Chamberlain told him he would gladly have given his left arm to have been born a German; now this was becoming an increasing reality in view of his being a "war cripple." At this time Chamberlain told Schroeder about plans for the editorial board of Deutschlands Erneuerung and the two discussed Schroeder's upcoming book about Chamberlain. Schroeder; Houston Stewart Chamberlain: Ein Abriss seines Lebens, pp. 94-96. 
to become an early member of the Nazi party. ${ }^{70}$ During World War One, the two men found strictly parliamentary measures inadequate in the face of increasingly serious domestic and military events. Their desires for "neue Standegliederung" replacing the Reichstag party structure found expression briefly with the Vaterlandspartei, founded in $1917 .^{71}$ After completing the series of medical treatments at the Bad Gastein Kur, Chamberlain conferred with Lehmann in Munich. This resulted in Chamberlain becoming an active editorial board member of the War Aims Movement journal published by Lehmann, Deutschlands Erneuerung. 72

Deutschlands Erneuerung was one of many publications attempting to drive the government away from internal reforms and toward simply continuing the war. It expressed a synthesis Chamberlain had come to support since he first began his nationalist metamorphosis. It was expressly published to further vilkische values, and to work for a "spiritual-moral, political and economic regeneration of Germany." It, praised Hindenburg and Ludendorff, claimed the need for huge additions to the Reich, and furthered the idea of race hatred. ${ }^{73}$ It was thus a 412.

70 "Houston Stewart Chamberlain: Prophet of Bayreuth," pp. 4l1p. 37 .

${ }^{71}$ Chamberlain to J. F. Lehmann, September 7,1916 , Briefe II,

${ }^{72}$ Chamberlain to Frylulein Sidonie Peter, October 10-12, 1916, Briefe II, pp. 40-44.

$73_{\text {From the available sources it is not clear how much actual work }}$ Chamberlain did for this magazine. He published only three articles in the journal during the war. Deutschlands Erneuerung: Monatschrift fur das Deutsche Volk, 1. Jahrgang (April to December, 1917). 
propagandistic instrument which allowed full expression to German nationalists. ${ }^{74}$ Chamberlain worked on the editorial board of the journal ${ }^{75}$ and continued to issue his own articles and books. 1916 saw the publication of his Deutsches Wesen, Ideal und Macht, and Harmer oder Amboss. ${ }^{76}$

Chamberlain always considered his correspondence with the Kaiser to be the very pinnacle of his achievement. In these letters the two patriots lauded each other's roles, and found the greatest community of interest. In a long, reflective letter to Wilhelm II early in 1917, Chamberlain recalled how the war had transformed even their relationship.

74 George Mosse Described Chamberlain as willing to use any tool available for furthering his aims; the generalization seems apt for his fellow workers in the prosecution of their quite specific war aims. Mosse, The Crisis of German Ideology, p. 96.

${ }^{75}$ Further information about the magazine is that,

The editorial board consisted of the historian G. von Below and H. St. Chamberlain, Class, Geheimat von Gruber, of Munich, who had also collaborated on the brochures, Generallandschaftsdirektor (ret.) Kapp, one of Bethmann Hollweg's strongest opponents, von Schwerin and the theologian, R. Seeberg, the inftiator of the so-called 'Intellectuals' Address.

Fischer, Germany's Aims in the First World War, fn., p. 340.

76 Listed in "Houston Stewart Chamberlain: Prophet of Bayreuth," p. 544 and p. 567. Chamberlain's already well-developed racial fears were heightened concerning Negroes during the war. He never perceived Blacks as human, and their appearence in Allied armies on the Western front seemed to him proof of his notion of an ultimate race war. As "Aryan" soldiers encountered these territorial troops, many writers saw their formerly nineteenth century racism transformed into quite modem perspective. Conflict for Chamberlain and many observers was thus the last and the only altemative for the very survival of mankind.

"Houston Stewart Chamberlain: Prophet of Bayreuth," pp. 496-497. 
He remembered their earlier letters when the two had been free to discuss primarily art and religion. But now, with America's entrance into the war, Chamberlain enlarged his thesis of Jewish, capitalist, materialistic comption to include specifically the U. S. A. He said that Jewish-dominated America had entered the Entente's struggle against Kultur. This "schrankenlosen Plutokratie" even dared to use the systematic poison of "seine Hauptwaffe" against pure German Idealism. 77 Chamberlain did not point out the German uses of unrestricted submarine warfare, poison gas and bombardment of civilian targets.

With 1917 and early 1918 the German side came close to mastering both its domestic and its intermational enemies. But, just as America's entrance helped tip the battlefield advantage against the increasingly exhausted Central Powers, so too did the home front begin to disintegrate. Even the new Vaterlandspartei was unable to fully co-ordinate a total effort in Germany. Advocating unrestricted submarine warfare, criticising clvilians as hindering the war effort, pressing for a "victorious peace," finding only Hindenburg and Ludendorff adequate symbols for national leadership, this new party foreshadowed many measures of the Nazi Gleichschaltung. ${ }^{78}$ Also in 1.917 such fellow Bayreuthians as Wolzogen, Friedrich Andersen and Adolf Bartels in company with Ernst Katzer published a programatic article, "Deutschchristentum auf reinevangelischer Grundlage 95 Leitsătze zum

${ }^{77}$ Chamberlain to Wilhelm II, January 20, 1917, Briefe II, pp. 251-252:

78 The party advocated unrestricted submarine warfare, harsh treatment of civilian dissenters, a victorious or "Slegfrieden," territorial gains in Belgium, northern France, Western Russia, and large colonies. Ringer, The Decline of the German Mandarins, p. 190. 
Reformationsfest 1917," which advocated the sort of inner unity extreme nationalists desired. Important in the German Christian movement, this article included the total identification of Christianity with Deutschtum, soul, Innerlichkeit and will. This was indeed a logical. furthering of Bayreuth ideas under the wartime pressures. Religion thus became increasingly racist, sealing of t' chances of dialogue, compromise, even toleration. A total ideology was being constructed. ${ }^{79}$

Chamberlain's articles in 1917 included "Der Wille zum Sieg," "Der Deutschgedanke," "Das eine und das andere Deutschland," in addition to the book, Demokratie und Freiheit. ${ }^{80}$ In particular, his essay "Deutsche Weltanschauung" was quoted and reprinted. In it Chamberlain enlisted the "army of German philosophers" and other cultural and national figures into war service. Hans Sachs, Dltrer, Holbein, Bach, Beethoven, Schiller, Goethe, Wagner--all were at stake in the present conflict. He claimed Otto the Great and Friedrich the Great, Luther, Bismarck, Scharnhorst, Moltke, Guttenberg, Gauss, Herder, Lagarde, Treitschke, Leibniz, Kant, Schopenhauer, Stahl, Humboldt, Baer, Bunciten, Helmholtz, List, Savigny, Dahlmann, Eckhart, Bthme, Schleiermacher: all of these men Chamberlain claimed had desired German Regeneration. ${ }^{81}$

${ }^{79}$ Chamberlain continued to produce his characteristic comment; in 1917. "Judaism and its closely related Americanism" was trying, to enslave the world with "boundless plutocracy." The World War was thus "the war of moderm mechanical civilization against the elemental old holy, eternally reborn Kultur of superior races." Viereck, Metapolitics: From The Romantics To Hitler, p. 9.

80 "Houston Stewart Chamberlain; Prophet of Bayreuth," pp. $567-568$.

${ }^{8 .}$ Chamberlain, "Deutsche Weltanschauung, in Rasse Und Peristnlichkeit, Aufsattze von H. St. Chamberlain (Munich: Bruckmann, 1925), pp. $\overline{9}-\overline{10}$. 
"Only Germans really are the represent,atives of the freedom of mankind," he wrote. ${ }^{82}$ The French and the English had lost their legacy of freedom, and had enlisted nearly all the nations of the earth in an unholy war against purest Germany. ${ }^{83}$

In the last year of the war, 1918, Chamberlain's productivity was greatly diminished. He published only the article, "Rasse und Nation" in Deutschlands Ermeuerung. This was principally a reprint of an earlier article he had written about Rumania. ${ }^{84}$ He was attacked frequently by the press in Germany, and had to defend himself in more legal actions. ${ }^{85}$ A particularly intriguing attack on him came from an Austrian professor, Leo Spitzer, who in 1918 published a booklet, "AntiChamberlain: Betrachtungen eines Linguisten Uber Houston Stewart Chamberlains 'Kriegsaufsätze' und die Sprachbewertung im allgemeinen."

${ }^{82}$ Ibid., p. 15 ${ }^{83}$ Ibid., p. 18. 84 The new title was "Rasse und Nation," in Deutschlands Emeuerung, 2. Jahrgang, vol. 7 (July, 1918). This also was printed as a flyer for 40 pfennigs, and distributed to help discredit the peace terms Kthlmenn had made with Rumania. It was reprinted at the behest of the ambituous General Ludendorff, who desired a stronger position in the East, au icl tor discredit his civilian enemies. The article was originally published as "thber die Judenfrage in Roumanien," in Nuova Revista Romana (Bukkarest) vol. $10(\overline{1900})$ and had been issued in Germany with Bruckmann's grreat, reluctance since it was quite anti-Semitic. It discussed the Rumanjar Jewish "problem" in terms of England and France, and was thought of as a far-sighted treatise by extremist contemporaries. Chamberlain stated that only by rooting out the Jewish "menace" could a truly national development exist in Rumania, or in any country. He believed this to be a moderate statement, one far short of the merely crude proposals of many early-century anti-Semites. Sumnary and analysis from "Houston Stewart Chamberlain: Prophet of Bayreuth," pp. 437-438.

${ }^{85}$ Chamberiain mentioned having to defend himself in a law suit: f'rom the Frankfurter Zeitung. His communications to his lawyers steern to indicate he was frequently embroiled in such difficulties. Chamberlain to Alfr. Jacobsen, November 21, 1918, Briefe II, pp. 53-54. 
This criticism claimed to be only Spitzer's protest as a "Fachgelehrter," concerned simply with science and Chamberlain's linguistic mistakes. It was, however, a very sophisticated and remarkably blunt attack not only on Chamberlain's linguistic errors, but on his entire racist methodology, the war and chauvinism. ${ }^{86}$

But with his illness, Chamberlain was confined to Bayreuth and found solace in this last year of war only through revising and

86 While Spitzer termed his comments only those of a "Fachgelehrter," against Chamberlain's scientific and linguistic misunderstandings, he stated that it was "incredibly serious" Chamberlain had mixed truth and falsity so intimately. Particularly, Spitzer stated the relationship between race and linguistics was really a "pseudowissenschaftliche" relationship, in which Chamberlain had confused particularities, psychological and linguistic data in a fruitless search for "origins." Leo Spitzer, "Anti-Chamberlain: Betrachtungen eines Linguisten Uber Houston Stewart Chamberlains 'Kriegsaufs im allgeminen," in whhrend der Milithrdienstzeit, Aufsdtze von Dz. Ir. Leo Spitzer (Leipzig: 0. R. Reisland, 1918), p. 5. He described Chamberlain's method of disecting writers with the hypothesis of a relationship to pure, free, "Aether des Geistes," particularly in the war essays. He noted the Foundations as well had used linguistic data to buttress race theory, and had been followed by many such illogical. constructions in subsequent Chamberlain works. Spitzer cited, for example, one of the war essays in which Chamberlain had tried to contrist French and German linguistic derivations for the words Revanche and Rache. Chamberlain's conclusion that the French war policy was consequently unfair, oriented toward revenge while Germany's interests were pure, was simply meaningless. Anti-Chamberlain, p. 10-12.

Spitzer concluded that based upon these many inconsistencies and errors, Chamberlain's conclusions were without warrant. He damned Chamberlain's circular logic, and stated that speech cannot teach about race, that race changes and language changes were not connected phenomena, and that even similar races speak different languages. Ho stated that the issue of which language was best was being fought out on the battlefields, and Implied that this struggle was absurd. Now that, language had become identified with national characteristics, Wagner'::; music had come to be associated in the popular mind with murdering children, and the sounds " $\mathrm{d}$ " and " $\mathrm{k}$ " had come to mean "Deutschland ther. Alles," and "Kaiser." The further identification of war effort with a delty Spitzer stated "shows a laughable dilettantische Pedanterie" confusing the real issues. Thus Spitzer sumed up much war writing, such as Chamberlain's, as illogical, superfluous, kindred with the pernicious militarization of science. Anti-Chamberlain, pp. 27-47. 
expanding his earlier works. He continued to prepare his theological speculations for publication, and he worked on organizing his autobiographical notes. This last-mertitioned work was intended for' publication in 1918; the war's end delayed its appearance until 191.9. But it needed only minor corrections to fit the changed conditions of' peace. Its pages resounded with proclamations of German fortitude, endorsing the essential rightness of a strong German world power. He defended himself from the charge that he was unacquainted with democratic processes. He recalled that, in his younger years in lenevat and in Dresden he had witnessed "party manipulation." He claimed that his entire life of studying and writing had fitted him to comprehend and evaluate current events. Thus, with the outbreak of war, he had been ready to take up the pen to defend his new homeland. ${ }^{87}$ With

${ }^{87}$ In his memoirs, Chamberlain made an extremely interesting analysis of Rousseau which shed light on his own mature Weltanschauurn: The usual German nationalist position was to read Rousseau as a symbol of alien democracy and foreign French culture. But, as Fritz Stern has noted, many of Rousseau's attacks upon reason, education and civilization were nearly synonomous with many of the more crude German nineteenth century attacks upon "modernity." Here, Chamberlain was an exception. As a student of the English, French, and German cultures, he always defended himself against these anti-Rousseau views. He maintained Rousseau was a psychologist, an analyst of human character beyond any merely ideological consideration. He praised much of Rousseau's Social Contract and Discourse on the Origins of Inequality, and exclaimed he wished one of his writings had won the Dijon prise. Lebenswege, $p$. 323. In Rousseau he recognized a relationship betwef:r "Genie und Wahnsinn" which was illustrated only too clearly in man's encounter with morality and custom. Lebenswege, p. 356. He insisted the French themselves had misunderstond Rousseau, that his failing was: in extending his consideration from art to those of a political and a "sozialen Tendenzschriftstellers." For Chamberlain, Rousseau intonded to fashion a realm rather for man's spiritual development, much as cloes a poet. Thus Chamberlain praised the Rousseau attempting to protect: individuality against modernity, even democracy and socialism. He found an affinity with Rousseau beyond politics, in the innocent realm of pure intention. Lebenswege, pp. 358-360.

The same sort of analysis has more recently been made by Errist 
obvious bitterness at the war's outcome, he emphasized the deepseated nature of his convictions. He ruefully stated the struggle for existence "kennt keine Bethmann-Hollwegischen Bedenklichkeiten. "88

Cassirer and Judith Shklar. But thi.is sort of cosmopolitan sophistication was otherwise quite absent from Chamberlain's wor'd Wiar era publications. I think it displayed his affinities with this notion of Rousseau, with sensibility and affect. He, however, did not evidently comphrehend the damage done to these views by his increasirngrly brutal political fabrications. Another consideration, as mentioned in Chapter VII, was that Chamberlain used this sort of non-political material to enlarge his reputation as a Kulturkritiker and to ease hiv reception as a "moderate." This perhaps should be balanced against, hi.s often pious proclamations of disinterest. It is difficult to separate such propagandistic aims from less pedestrian goals in the entire body of Chamberlain works.

${ }^{88}$ Lebenswege, p. 31. 


\section{CHAPTER IX}

ART AND IDEOLOGY

\section{THE VERRÄTERREPUBLIK}

The defeat and revolution ending 1918 was a catastrophyparticularly for the nationalist Germans. They had been led to belisve victory was within their grasp; now it seemed all the efforts of the past five years had been in vain. The Wagnerian cause shared in this moral collapse with war's end. The changes in Germany's internationiil and domestic situation all rebuked Wilhelmine aspirations: continued blockade, Revolution, Diktat and Republic. Wagnerism partook of this: inglorious transition, as the discrepancy became manifest between the ideals and the contemporary reality, between the hopes and the possibilities for Germany. Disillusionment on a spiritual level thus added to the confusion stemming from a lost war.

During the interwar period of tre 1920's and 1930's, the Krej:;'s social-cultural observations sharpened and intensified in tone. Wapnerians were sympathetic to conservative interests, but not entimily synonomous with them. ${ }^{l}$ They usually favored govermmental insi.itutions: such as law and the military, but the transformation from Monarchy to Republic helped undercut this nominal respect. The vblkische tendercies in Wagnerism helped to disparage the day's leaders, inculcating in their

\footnotetext{
${ }^{1}$ Der Bayreuther Kreis, pp. 75-77.
} 
stead a yearning for trans-political ideals. The cultural reforms which had flourished under the auspices of the Bayreuther Blatter were increasingly politicised. The Kreis became part of the rightist opposition in the Weimar Republic, engaged in the ideological struggles which essentially refought the previous century's battles with modernity. Wagnerians were frequently included within the "conservative revolutionary" wing of critics; they sought to modify the heritage of bourgeois democracy institutionalized in the un-loved Republic.

Characteristically this amorphous group sought a "third force" embracing corporativism and the Rechtstaat. ${ }^{2}$ They wanted a volikische integration, but above all they hoped for the destruction of the liberal and democratic ideologies. The treasured concepts Gesellschaft and St Inde were increasingly important for frustrated aesthetes. 3

Wahnfried shared in the general economic, as well as the spiritual. collapse of the war's end. The Wagner family continued to seek support. for reopening the Festspiele, but unsuccessfully until the mid-1.920's: prosperity. Chamberlain's finances were also chaotic. Allied currency

2 This "conservative revolutionary" movement, was termed by Georpe Mosse to be the "left wing of the volkische movement," which embraced is Hegelian interpretation. Mosse, Germans and Jews, p. 118. This may be: usefully contrasted with Ernst Cassirer who placed them beyond llege 1 , rather as lying with the modern irrationalism of corrupted romanticism. Cassirer, The Myth of the State. Frequently these right wing neoconservatives were closely identified with the writers around the journal Die Tat of Arthur Moeller van den Bruck (1876-1925). Bruck continued the critical traditions dear to Wagnerites, damning the "exhausted" Italians while he praised the potential of Germans if thoy colld resist "materialism." His Das Dritte Reich (1923) was a mystjcal hym to this "third force" of aesthetic striving. It was corrupted into Nazi parlance, making of Bruck a symbol of their quite concrete movemut. The alscussion of this problem is by Stern, The Politics of Cultural. Despair.

3 Der Bayreuther Kreis, p. 245. 
controls prevented all but covert transfers of foreign monies into Germany. His brother, Basil, helped him, as did the rest of the Chamberlain family in England. ${ }^{4}$ Ther was no immediate market for his just-completed memoirs, and his publishing efforts were minimal. Chamberlain already shared in the problem faced by younger sons of the day's aristocracy in being less well provided for than were his older. siblings. But now, with the inflation and the investment losses in the postwar period, perhaps finances contributed to color his usidallyoptimistic spirits. 5

With the November Revolution he wrote, "God's way is not our way; what holds for the individual is true as well for the ration." ${ }^{6}$ He folt isolated when he read the newspaper. An officer from a local soldier': Council visited him and confirmed his worst fears concerning the sentiment in the military. But Chamberlain never abandoned himself' completely to the nihilism many thought was overtaking Germany. He believed he lived "with my times," in keeping his portraits of the Kaiser and Prince Max of Baden before his eyes. He said the Revolutinn nearly caused him to lose his senses. ' Accordingly, he attributed trif: war's loss and the onset of republican govermment to a conspiracy of

"These actions helped Houston and Eva to survive the inflation of. the 1920's. "Houston Stewart Chamberlain: Prophet of Bayreuth," p. 547.

5 Field noted it is not possible to entirely separate financial from less menial considerations in Chamberlain's Weltanschauung, particularly in the deepening hysteria of the interwar period. Ibid., pp. 550-55].

${ }^{6}$ Chamberlain to Alfr. Jacobsen, November 21, 1918. Briet?e II, 0.54. 7 Ibid., pp. 54-55. 
Jews and English agents. He quoted lloyd George that Germany could not be destroyed from without, only from within. And he predicted there would be a long series of fratricidal conflicts in the collapsing; Hapsburg Empire. ${ }^{8}$ Deeply depressed, he considered the possibility that internationally the German language might be replaced by English. He compared himself to the early Christian martyrs, struggling to keep before him a vision of the ideal. But he never lost his tremendous sense of direction and spiritual certainty. In the midst of the dav's "anarchy and terror," he used a pseudonym in letters, "H. S. Grundleger" --he had not entirely given up the struggle for his vision of Germany. 9

Asked by many to write to President Wilson, to the Kaiser, to the German people appealing for help in 1919, Chamberlain refused. His believed any acknowledgement of the Allied victory would sanctify, somehow endorse the republican domestic consequences he despised. Iiver before Christmas, 1918, he maintained he had "the unshakeable faith now as before--that God had selected the Germans to prosper as the most noble representatives of mankind." 10 The activities of a Munjch

${ }^{8}$ Ibid., p. 55.

9 Ibid., pp. 57-60. After the war, and until 1926, Chamberlain attempted to recover his English investments. This occasioned attack: or him in the German press. He was disparaged as a false patriot, because of his concurrent. Teutomaniac publications. He recovered nothing. The English considered him a traitor and his funds to have heen forfeit to England. They were considered part of the reparation payments owed to England, and he was referred to the German governmont. for compensation. He was nearly dependent upon relatives and frierkis: until he died. Upon his death there was no money for his wife Eva, mly his publication revenues until 1935. She was, howevers, aided by Bail Chamberlain and German friends. "Houston Stewart Chamber'lain: Frophet; of Bayreuth," pp. 546-549.

${ }^{10}$ Chamberlain to Vice Admiral a. D. von Seckendorff', December il/, 1914, Briefe II, pp. 60-62. 
"Council of Intellectuals" he was invited to attend were--to him--not in the best interests of Germany. He believed the council spent its time discussing whether students should have the right to help decide the school calendar. 11 This sort of criticism of the brief experiment in council government was rampant on the German right, and was shared by many people hesitant about measures smacking of "Bolshevikism." Chamberlain's feelings of being "on an island" in the midst of such activities were shared by many Germans. He noted the day was seeing: the ephemeral triumph of "the westlyndischen Barbaren." What would arid must prevail would be his cultural linking of the great figures in German history. 12

Realizing that the current generation of Germany's youth was buried in many foreign lands, he placed his faith in the next generation. He dedicated himself to helping instruct that generation so it could realize his hopes. 13 He continued to hate France as a vengeful neigthor who simply desired discord with Germany. The current boundary revisiuns in Europe he believed would only result in "Chaos." He said that now the Balkans started at Hamburg. ${ }^{14}$ But he still hoped for a regenerdion p. 63 .

${ }^{11}$ Chamberlain to Emst von Meyenburg, December 28, 1918, Briefe II, ${ }^{12}$ Chamberlain to Maler Croeber, January 6, 1919, Briefe TI, p. 68. 13 Fortunately for Chamberlain, a libel suit against him in Harntures was dropped as part of a general amnesty. Chamberlain to Arthur. Diriter, March 7, 1919, Briefe II, p. 83.

${ }^{14}$ Chamberlain to Count Manfred Gravina, May 16, 1919, Broiefe II, p. 90. He gratefully acknowledged the receipt of Admiral Tirpitz' memoirs, and praised it as one of the "tragic" documents of world literature, tracing, as it did, the struggle of Germany agairst a hostile moderm world. Chamberlain to Tirpitz, November 16, 1919, Bricie II, pp. 102-104. 
of such concepts as "Mitteleuropa" which might form a strong bulwark from Germany to Damascus, even Teheran, free from "piratical" and "industrial oppressors": i.e., the West. Thus, he hazarded the guess that with the war's loss, perhaps God had not really tested the German people and found them wanting. He felt, and hoped, this experience had simply been a mistake which in the future would yield to a German regeneration. 15

Chamberlain reinforced the day's nationalist interpretation of war guilt and the responsibility for defeat. In his 1920 foreword to a new edition of his Goethe he referred to his wartime essays as still-livirig, documents for Germany. ${ }^{16}$ His publications were largely reissues of his earlier-written material. His Mensch und Gott (1921) was quite important in the evolving German Christ,ian movement, and was the subject of a reflective series of letters between himself and the former Kaistr. Wilhelm, now exiled at Doorn, Holland, praised this theological book. He said it was a revelation, a new Reformation which Chamberlain had fortunately offered to the German people. 17

The two men took pleasure in the publisher J. F. Lehmann's currert distribution of a series of small books supporting the stab-in-the-back

${ }^{15}$ Chamberlain to Czar Ferdinand of Bulgaria, December 11, 1919 , Briefe IT, pp. 107-109.

${ }^{16}$ Chamberlain, Drei Vorworte (Munich: Bruckmann, 1923), pp. 6-7.

17 Wilhelm to Chamberlain, November 17, 1921, Briefe II, p. 260. Chamberlain wrote a letter asking after the Kaiser's health in which he expressed the grateful thanks of "alle aus dem Wahnfrieder Kreise." Chamberlain to General 0 . von Chelius, December 5,1921 , Briefe II, p. 117. 
thesis. ${ }^{18}$ wilhelm was certain the real reason for the revolution and the lost war was an inner, religious collapse. This was personified for the ex-Kaiser and for many Germans by the Jews. He hoped for a "fresh religious nourishing" which would help reconstruct the Reich. Wilhelm proposed a series of educational reforms to Chamberlain common to many nations in recent history. First, schools should stress Heimatsgeschichte, then the German language, then other nation's histories. Geography as well should bie taught first on the local, thich state, then the international level. Such holidays as Christmas should be viewed as an exemplary instructional opportunity, where the holy could be combined with the national. In this religious interpretatiun, Wilhelm was much taken with Chamberlain's thesis and the German Christian movement. He sought to argue the Zoroastrian, not the Jewish origin of Christianity, and believed that through preachirg the divine nature of Jesus, "pessimism" and "atheism" could be banished from Germany. ${ }^{19}$ Wilhelm was quite convinced of the Aryan origin of Christ, and agreed with Chamberlain's accent on religiosity within Deutschturn. ${ }^{20}$

Though Chamberlain was ill and increasingly unable to even keck up his correspondence, he was still a popular figure in the town of Bayreuth. In 1922 he was given the keys to the city. ${ }^{21}$ Also in 1922,

${ }^{18}$ These books bore such titles as Im Felde unbesient and Aur Siee unbesiegt. Chamberlain to Wilhelm. November 30, 1921, Briefe IT, p. 761.

${ }^{19}$ Wilhelm to Chamberlain, November 30, 1921, Briefe II, pp. irjl-273. 20 Wilhelm to Chamberlain, June 3, 1923, Briefe II. p. 274.

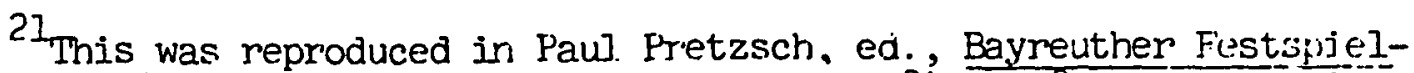
flihrer: 1928 (Bayreuth: Georg. Niehrenheim, 1928), p. 85. Chamber] ain wrote a letter thanking the mayor of Rayreuth, June 2, 1922, Briefe II, 
he dictated a new introduction to an edition of the Foundations. In this he declared that his hope still risided in the noble co-operation of people of Germanic blood. He even hoped for a "Zusammengehen" of Germany and England, but he noted the great incursions made into national life recently by Jews, "crypto Jews," and the press. 22 Decrying Anglo-American co-operation against Germany, he nonetheless believed "Hope is Duty. And we are permitted to hope for a great rebirth." 23 He was sure that if Hinderiburg and Ludendorff had led the war effort from the first day, a different result would have occurred: peace would have surely been "dictated" from Paris in 1914 as it had been from Versailles in 1871. He believed that Germany was robbed of success in 1917 by the Reichstag peace discussions, the "Friedensverhandlung," arguing that continuing unrestricted submarine warfare would have turned the tide of battle. He reiterated the common right ist assertion that the German U-boat effort would have succeeded had it been started earlier, and if it had not been "sabotaged" from within by dissent. 24 He quoted a revisionist war-guilt article by Hindenbure: t.e, the effect that only the enemies within the Reich, most particularly in the Reichstag, had betrayed the war effort. ${ }^{25}$ For Chamberlain, the

pp. 120-121. In this response, Chamberlain warmly recalled it had bren thirty years since he had first come to visit Bayreuth.

${ }^{22}$ Chamberlain, Drei Vorworte, pp. 9-11. $\quad 23$ Tbid., p. 12.

24 This was based on the remarks of an English representative ai, the Washington Marine Conference, Admiral Lee. Ibid., p. 14.

${ }^{25}$ Hindenburg's article was "Wie Deutschland revolutionier.t wurde," Deutschlands Ermeuerung (December, 1921); quoted in Chamberlain, Dpri Vorworte, p. 16 . 
"decline of the west could only be averted by Germans utilizing duty, decisiveness and deeds in the critical hour. 26

Chamberlain was almost entirely paralyzed from the end of the war until his death in 1927. He dictated letters in a hoarse mutter only his loyal wife could interpret. Amid the inflation, the Ruhr occupation, and the various coups during the unsteady early 1920's, Chamberlain was a forlorn observer, unable to command more than token recognition for his efforts on behalf of German greatness. With great personal courage he endured increasing pain, waiting for death. As he said in a 1923 foreword to the reissue of his collected works, all his life he had worked to further his idea of God and Deutschtum. He believed his work as a whole formed a single unity, that this could be best described as the nurturing of personality -- especially racial personality, i.e., the "Nordic race." 27

26 Ibid., p. 19. In the Weimar Republic, a dialogue was carried un between the two opposing interpretations of civilization's "decline": the incurable optimism of Chamberlain and the quite pessimistic view of Oswald Spengler. While both men used the metaphorical image of the Aryan walking sublimely along the precipice of modern life, Chamberlain believed that the very circumstances of modern life could be altered by an invigorated consciousness of rece; for him it was not too late to avert a real Untergang. However, for Spengler it was important to impress contemporaries with the ineradicable nature of decline: only "heroic pessimism" was possible. Several of Spengler's publications in the Weimar perind fueled this dialogue, especially his "Prussianism and Socialism" (1920) and "Pessimism?" (1921) found in Oswald Spengler, Selected Essays, irans. Donald 0. White (Chicagc: Henry Regnery Company, 1967). This vas also discussed in Rudolf Grabs, Paul De Lagarde und H. St. Chamberlain, Wegberester deutschen Crristentums series (Weimar: Verlag Deutsche Christen, 1940), p. 54.

27 He recommended another popular racist book which found approval as well with the Nazis, Hans Gunther's Rassenkunde des deutschen Volkes (Munich: J. F. Lehmann, 1922). Chamberlain he ijeved this to be a work dedicated to the most elevated, free and roble Geistem. Chamberlain, Drei Vorviorte, pp. 32-34. 


\section{APOTHEOSIS}

In the 1020's, as the first and second generations of the Bayreuth Fulturkreis awaited death amid the wreckage of the old orcler, new political forces were rising in Germeny. 28 The National Socialist German Worker's Party was capitalizing on internal conflicts and the Weimar Republic's tolerance, especially in particularistic Bavaria. Despite the limited political significance of the party tr:roughout most of the 1920's, its leader, the young Adolf Hitler (1889-1945) early sought Wahnfried support. In 1921 a letter on his behalf was sent to Siegfrjed Wagner's wife, Winifred. ${ }^{29}$ Winifred Wagner (née Williams) was a particularly apt recipient for such entreaties. She had been an English orphan adopted by the Wahnfried friends Karl Klindworth and his wife. The Klindworths had raised the girl in the German misjcal traditions of the early century, and had brought her to meet the middle aged bachelor Siegfried Wagner at Bayreuth. The match was agreeable to Cosima and her son, and in time led to two male and two female offspring. These children both brightened the old age of the Wahnfried residents and guaranteed continuance of the Wagner line. 30

28The parallel was perhaps not lost on contemporaries between the end of Wagner's Ring where Wotan had ordered the World Ash Tree of wisdom to be cut down and. piled up about Valhalla preparatory for the final destruction of the Gods and this time in the late 1920's. Now Cosima, her son Siegfried, and her son-in-law Chamberlain all waited their deaths. The difference with the operatic scenerio was that the first and second generatiors of Wagners and Wagnerites did not live to see the very real political Nazi Gobterdalmmerming.

29 Der Bayreuther Kreis, pp. 84-85.

30 It was a singular and often-discussed circumstance that many of 
The early 1920's were, however, a difficult time for Bayreuth.

Siegfried Wagner was attempting to secure enough support to reopen the

Festspielhaus. He looked at this effort as imcortant for Germany, and

he sympathized with conservatives in the Republic. He, however, believed

in music, was apolitical like many artists and intellectuals, and thought

that the reopening of the Festspiele would embody a musical regeneration

for Germany. 31 He even disparaged anti-semitism and apparently believed

there was no merit in crude racist slanderings of Jews.32 But Winifred's

the quite strongly affected personalities of both Wagnerism and National Socialism were not native, but convert Germans. That is, Cosima, Chamberlain, Winifred, Rosenberg and Hitler were all for'eign born. While in the cases of Rosenberg and. Hitler it is arguable their Teutomania was partly the result of the tensions of German ethnicity in Eastern Europe, the English-born Chamberlain and Winifred present a more complex problem. Their gravitation to the "causes" of super, trans-nationalism and art. perhaps demonstrate deeper, nearly paranoid fears with the: contradictions of life in the West. As previously noted, their enthusiasm almost invites the usage of psychological terms such as sublimation, compensation, identification and masochistic-sadistic catharsis. p. 145 .

31 Siegfried Wagner, Erinnerungen (Stuttgart: J. Engelhorn, 1923),

${ }^{32} \mathrm{He}$ wrote a famous letter which was published in Germany stating this thesis. However, it was generally believed trat he was, as an artist, dependent upon Jews, and would have been financially throttled had he become known as an anti-Semite. The issue is not clear even today. According to one author,

....Siegfried, for all his liberaljsm, shared the Wahnfried philosophy of Germar supremacy. Hitler, as a close friend of his young wife Winifred, was a frequent guest in his house, and there is no evidence that Siegfried realized exactly what Hitler would eventually become or that he, any more than his father, would have approved in practice what seemed good in theory. One knows from a much-quoted letter written in the Twenties to a fanatical German nationalist that Siegfried vigorously refused to countenance the idea of excluding Jewish artists from Bayreuth, where for him only artistic rules applied. However, this is less a proof of political conscience than an indication of complete indifference towards politics. 
daughter Friedelind clajmed her mother had joined the Nazi party as early as 1920 or 1921.33 Schllier noted this had been really later, in 1926. But this would have been difficult to verify in any case since the early Nazi membership cards, before 1924, were unnumbered. 34 In any event, the enthusiasm of Winifred seems to have caused some friction in the home. 35 The Wagner women were believed to be virulent Nazi supporters.

Political affairs had been observed as well by the invalid Chamberlain. On September 30, 1923, at the Deutscher Tag ceremonies, Hitler himself spoke at a rally in Bayreuth. He had just been at the larger Nuremberg German Day rally, but took the opportunity to follow this with the ceremony at Bayreuth. Winifred Wagner was escorted to the

Geoffrey Skelton, Wagner at Bayreuth, Experiment and Tradition (New York: George Braziller, 1965), p. 113. Siegfried, in any case, did not hesitate to use a common phrose of rightist origin in castigating art he disliked. When Otto Klemperer had the audacity to stage Der Fliegende Hollander in modern costumes, Siegfried called this "Kulturbolschewismus." Otto Friedrich, Before The Deluge: A Portrait of Berlin in the 1920's (New York: Avon Books, 1972), p. 206. Winifred certainly claimed her huskand was sympathetic to Hitler, and believed he refused to join the Nazi narty only to protect the: Festspiele. Der Bayreuther Kreis, pp. 84-85.

33 Friedelind was herself something of an errant child, who fled Nazi Germany to work for the Allies as a propagandist during the Second World War. She was not reconciled to the family uritil 1952. Friedelind Wagner and Page Cooper, Heritage of Fire: The Story of Richard Wagner's Granddaughter (New York: Harper \& Brothers Publishers, Inc., 1945), p. 30.

34 This is stated by Friedelind, who as well claimed that both Chemberlain and Winifred were issued cards in the 80,000 number ranfs: after Hitler was released from Landsberg prison. Ibid., p. 30.

35Ibid., pp. 105-106.

36Pridham, Hitler's Rise to Power, p. 13. 
rally by the Nazi author, Oskar Dbring, who then brought her to a reception given by the wealthy Bechstein family. The Bechsteins lived next to Wahnfried, and their daughter, Helena, was a great Hitler erthusiast. At their reception at the Reitschule, Hitler and Winifred met, and arranged for the Fllhrer to meet Chamberlair. Iater that evening, Hitler was escorted into Chamberlain's sick room, where he found his arm clutched by the ill author. In their short interview, Chamberlain mumbled in a barely audible voice, "Gott segne Sie!"37 A second meeting took place between the two in Wahnfried's gardens the next day, and Chamberlain sat at a window while colums of S.A. trecopers marched past Wahnfried in his honor. ${ }^{38}$ After these meetings, the enthusiastic Chamber]ain drafted a letter endorsing Hitler which began, "Most Esteemed terr Fitler!"

... I have been constantly mulling over the question as to how it was that you, a man who stirs the dorment anci the lazy to their very soul, have recently given me an invigorating; repose such as I have not experienced since that fateful day in August of 1914 when this invidious illness overtook me. Now I think I understand that this result of your visit nirroxs; quite accurately the essence of your character, that which envelops it, so to sireak: the true awakener is at the same time a dispenser of repose.

You are not in ary wise a faratic such as you have often been clescribed to me, rather, I would cs?.l you the exact opposite of a fanatic. The fanatic makes one's head spin, you warm the heart; the fanatic wants to shout you dcwn, you want to convince, ever to convince-arid you succeed in doing this. In addition. I would consider you to be the antithesis of the politician--using this word in the popular sense--since the essence of all politics is party membership while your aim is the dissolution of all parties in a grand imrolaticn drawirg its flames from love for the? Fatherland. It seems to me that it. was the risisfortine of 1 he

37Dbring, Ein Deutscher namens Chamberlain, p. 34. ${ }^{38}$ Ibid., p. 38. 
great Bismarck that he too was drawn, in the course of eventscertainly not because of any personal leanings in this direction-into the vortex of party politics. May you be spared this fate!

You have great things to accomplish, but, in spite of your great strength of will, I do not see you as the mere beast of brute power. . .

The fact that you brought me repose is largely due to your eyes and to the gestures of your hands. Your eyes seize hold of a men and hold him fast, and it is your way to direct your speech to a particular person among your auditors, at any given moment--I noticed that this is characteristic of you, and I may add that it is consonant with the way in which you use your hands, a usage so effective that the hands compete with the eyes in expressiveness. Any man possessing these qualities is truly capable of bringing repose to a poor, anguished soul! This is especially true if he is dedicated to serving the Fatherland.

My faith in Deutschtum has never wavered for a minute, but I must admit that my optimism had ebbed quite a bit. You have transformed the state of $\mathrm{mr}^{r}$ soul with one blow. That Germany in the hour of her greatest need has brought forth a Hitler bears witness tc her basic health; the same may be said of the things which this product will accomplish, for these two factors-individual personality and its effects--belong together . . . After seeing you I could have gone to my final rest without any sense of burden or anxiety. May God stand by you!

\section{Houston Stewart Chamberlain 39}

Witr the failure of Hitler's Munich Putsch later in 1923, Wahnfried became more fervently pro-Nazi. The perhaps apocryphal statemert was even made that Winifred had herself fumished the writing materials Hitler used to assemble his Mein Kamp while he was incarcerated at Iandsberg prison. 40 Though the Hitler movement appeared finished at this

39Chamberlain to Hitler, October E, 1923, Herzstein, "The Wagnerian Ethos in Terman History," pp. 327-32a.

${ }^{40}$ Heritage of Fire, pp. 104-105. 
time, Chamberlain joined the party and on Hitler's birthday, several months later, April 24, 1924, he sent the Fllhrer a congratulatory letter. ${ }^{41}$ Chamberlain sumed up his earlier favorable impressions of Hitler and further termed him a "gift from God" for the German Fatherland. 42 While at this time a rebirth of National Socialism appeared impossible, Chamberlain and Winifred, at least, kept the faith. Again, in Au:gust of 1924, Chamberlain wrote another letter praising. Hitler, pleading for all Germans to unify themselves behind the leader of the vUlkische movement. The Nazi newspaper, VUlikischer Beobachter, honored Chamberlain with a five colum editorial on the occasion of his 70th birthday. The Foundations were termed "the Gospel of tre vblkische movement." And duririe the next month Hitler appeared at a Nazi party meeting in Bayreuth honoring Chamberlain. 43 The letters from Chamberlain were justly termed a "clearly illuminating example of the inner relationship of Adolf Hitler to the Bayreuth Kulturkreis. 44 Nazi "intellectuals" such as Arthur Baeumler and particularly Alfred Rosenberg drank deeply of Chamberlain's wisdom.

When Chamberlain finally died January 9, 1927, he was still convinced Hitler would realize his own hopes for a new Germany. The

41One Nazi source stated Chamberlain joined as early as 1920 . I cannot refute this from the available sources, but I rather suspect Nazi. motives when it came to establishing pedigrees for their precursons. Dippel, Houston Stewart Chamberlain, p. 10.

${ }^{42}$ Chamberlain to Hitler, April 24, 1924, Dobring, Ein Deuteclier. namens Chamberlain, pp. 36-38.

43Biddiss;"Houston Stewart Chamberlain," p. 17.

${ }^{44}$ Faul Blllow, AdoIf Hitler urid der Bayreuther Kulturkreis, Aus Delutschlands Werden series, vol. 9 (Leipzig: Gustav Schloessmann, n.d. late $\left.1930^{\prime} \mathrm{s}\right), \mathrm{p} .5$. 
January 12 funeral was attended by the former King of Bulgaria, by the Crown Prince (representing the exiled Wilhelm), dignitaries of the town of Bayreuth, Siegfried Wagner and Adclf Hitler. S.A. and Stahlhelm troopers carried his bier to the grave, which was dominated by a gravestone inscribed with Runic characters proclaiming Chamberlain's love for the art of Richard Wagner. ${ }^{45}$ He was followed three years later in ceath by both Cosima and Siegfried Wagner. Now the Nazi appropriation of Wagner, Bayreuth and Chamberlain proceeded withcut hindrance. V8lkischer Beobachter devoted a great deal of attention to Chamberlain's demise. The Tuesday, January 11, 1927 issue carried a front page headline of the news of his death in one-inch type. A small article informed the readers that one of Germany's greatest cultural leaders, and the son-in-law of Richard Wagner, was dead. As the "Vorkympfer" of a new cultura]. ideal in a materialistic world, Chamberlajin would be sorely missed in Germany. As a "fanatische" warmior he had encouraged the Nazi party. The next day's issue carried a fill page on Chamberlain, referring to him as the "Bayreuth tr.1nker" who sought a Germany beyond mere parliamentary manifestations. Fxcerpts from Rosenberg's forthcoming book on Chamberlain were given, as were citations from Chamberlain's writings. Many notices of the republication of Chamberlain's books appeared in succeeding issues of the Nazi paper, tied in often with erticles linking wagner to the day's struggeles with parliamentary government. 45

${ }^{45}$ Ein Deutscher namens Chamberlain, p. 38.

${ }^{46}$ The issues of v8lkischer Eeobachter from January to March, 3.927 , referred extensively to Chamberlain and Eiayreuth. Great effort was made 
The institution of the Bayreuth Festsplele had been part of a general nineteenth century development in art and politics which in turn spawned other nationalistic ceremonies in the first half of the 20th century. 47 In 1926 Deutsche Festspiele in Weimar were modeled on the example of Bayreuth. Youth of the day was particularly fascinated with the model of Wagner's word-tone-dramas. Nazi Wagnerites such as Paul Pretzsch and Otto Daube attempted to recreate "Hellenic" traditions in the day's Germanic ceremonies. 48 Many of the grandiose Nazi efforts from Thingspielen to the immense Nuremberg party rallies attempted to coopt Wagnerian-inspired "total art" for the new mass movement. 49 Under the stewardship of the ardent Nazi Winifred, Bayreuth became even more extreme in political identification. Winifred did strive mightily to maintain the Festspiele, a task which had nct been easy even for the Meister and the Meisterin. She and her two sisters-in-law, Daniela and Eva Chamberlain (1867-1942) attempted to carry the burden of the performances, but found help particularly welcome from the new Nazi government.

Winifred appointed Richard Strauss and Wilhelm Furtwăngler

by the Nazis to identify even the town of Bayreuth with their movement. They held "Wagner evenings" and stressed the linkage of Wagnerism and nationalism. Prichard, Hitler's Rise To Power, p. 108. Also, popular books were printed extolling even the town of Bayreuth's identification with the new political movement, eg. Paul Blllow, Bayreuth: Die Stadt der WagnerFestspiele (Leipzig: Bibliographisches Institut, 1936).

${ }^{47} \mathrm{Cf}$., Mosse, The Nationalization of the Masses.

${ }^{48}$ Der Bayreuther Kreis, p. 215.

${ }^{49}$ Even Wagner's music was woven into such propaganda instrument.c as the film, Triumph of the Will. 
conductors, and secured the Intendant of the Prussian State Theatres, Heinz Tietjen, as the Festspiele director. This combination assured the Reich popularity of Bayreuth as well as a supply of talent from the largest state theatre system. While Winifred was able to secure exemptions for Jewish performers at Bayreuth long after they were eliminated in the rest of the Reich, increasingly the ideological position cf Bayreuth made a purely German institution of Wagner's art. ${ }^{50}$ Ironically, this at last seemed to realize the Wagnerian goal of making the Meister's art a national celebration. Hitler himself granted 50,000 marks yearly from his own funds to Bayreuth, and he saw that the enterprise was exempted from Reich taxes. While it is not clear if the Nazi sponsorship was as genercus as it was thought to be by contemporaries, certainly Hitler was only too pleased to be identified with the Wagner name and to occasionally join the family at Wahnfried. ${ }^{51}$ There were speculations the Fllhrer might marry Winifred, but their warni relationship appears to have served its purpose quite independently of any romantic interest. 52 Winifred saw him as the "good uncle from Bayreuth" who could feel at home in the Villa Wahnfried. He was nearly a father to her children, and they retained close ties to him up to

${ }^{50}$ Skelton, Wagner at Bayreuth, p. 16.

$51_{\text {Friedelind Wagner, in her Heritage of Fire and the revisionist }}$ Herzstein in his "The Wagnerian Ethos in German History" botr: maintain that the actual aid received by tre Festspiele was far less than supposed. It is not possible to verify these charges from the available sources.

52 This is maintained in Frledrich, Before the Deluge, p. 228 and in Geoffrey Skelton, Wieland Wagner: The Positive Skeptic (New York: St. Martin's Press, 1971) p. 22. The latter cites a provision in Siegfried's will which made his widow's ownership contingent upon her not remarrying; otherwise the Festsplele ownership would have passed tc the town of Bayreuth. 
December, 1944. Winifred herself last saw Hitler in 1940, but the two continued to exchange letters and telephone calls. In cormon with many other accounts of Hitler, Winifred's account of the Fuhrer was that of a gemlltich bourgeois playing at art, that he "was an entirely different person from the dictator of Germany that the rest of the world knew. In Wahnfrled he could be relaxed and human." 53

National Socialist hagiography portrayed the close identity of Hitler, Wagner and Chamberlain. 54 Dr. Paul Blllow wrote, "Chancellor Adolf Hitler is himself a warm-hearted friend of music and in particular is a deep and true admirer of Richard Wagner. "55 Certainly this inierpretation was the official view for Germany from 1930. However, under Hitler the Nazis in fact were very selective about utilizing both Chamberlain's and Wagner's thoughts. Minor changes were made in inter-

53Der Bayreuther Kreis, pp. 84-85. In common with many other accounts of Hitler, Winifred's is that of him being a quite wonderful man who was led astray by some of his less cultivated associates. Skelton, Wagner at Bayreuth, Experiment and Tradition, p. 140. However, the ubiquitous Friedelind had some remarkable tales in her own book about this subject. She depicted a Hitler who was genuinely concerned with maintaining the Wagner family and institution, even to the point of listening to her lectures on politics. Albert Speer also discussed trese days in his Inside the Third Reich; Memoirs by Albert Speer, trans. by Richard and Clara Winston (New York: Avon Books, 1970), po. 208-209. One does wonder, however, how Hitler's statements about how he was certain any new war would see the immediate destruction of Bayreuth should be interpreted.

${ }^{54}$ George Nosse argued Bayreuth's political orientation combined with art was a rather common pattern in the pre-Nazi period in Germany. Hitler was awed by the Wagner circle, which to so many on the right represented the living of a truly German life. But he was also taken with Wagner's construction of his festivals, with the way in which he presented the "Aryan soul" on the stage and through his music. Though Hitler was to value this dramatic form less than festivals in which the pecple could actively participate, the Wagnerian tradition was kept alive. Mosse, The Nationalization of the Masses, p. 109.

55 Blllow, Adolf Hitler und der Bayreuther Kulturkreis, p. 5. 
preting such figures of history as Charlemagne. While Chamberlain had praised him as a Teutonic hero, for the Nazis he was a detested symbol of the West, a "Saxon Slayer." 56

More significant were the thoughts of the "mature" Hitler about Chamberlain and Wagnerism which were published only after World War Two. Where Chamberlain had been nearly eccentric in his praise for St. Paul, Hitler termed the apostle a "proto-Bolshev1st." Moreover, instead of believing in Chamberlain's maudlin piety, Hitler was a Darwinistic vitalist who loved "struggle." The Fllhrer ridiculed Christianity, and hoped to replace it with merely civil ceremonies which would enshrine a concept not of afterlife, but of life on this earth. He said, . . . In my view, H. S. Chamberlain was mistaken in regarding Christianity as a reality upon the spiritual level. Man judges everything in relation to himself. What is bigger than himself is big, what is smaller is small. Only one thing is certain, that one is part of the spectacle. Everyone finds his own role. Joy exists for everybody. I dream of a state of affairs in which every man would know he lives and dies for the preservation of the species. It's our duty to encourage that idea; let the man who distinguishes himself in the service of the species be thought worthy of the highest honors. 57

While Hitler still fondly remembered his early days when he recelved letters from Chamberlain and was on "Christian-name terms" with Wahnfried, ${ }^{58}$ he himself was a part of the Kreis interpretive problem. 59

56 Snyder, German Nationalism, p. 251.

57Hitler, Hitler's Secret Conversations, \#75, December 13, 1941, pp. 117-119.

58 H1tler believed Siegfried had been his friend, but to avold the wrath of the Jews had had to remain a political neutral. Hitler's Secret Conversations, \#167, 28th February - 1st March, 1942, pp. 283-284.

$59 \mathrm{Hitler}$ had been close to the Wagner family in the 1920's, but by the time of World War Two evidently confused names - or his transcribers did. He recalled how Cosima Wagner had brought him flowers when he 
The Nazi usage of art had diverse practical goals seldom seen by contemiorary Wapnerites.

Praise of Chamberlatn became pro forma in the Third Reich. Goebbels lauded Chamberlain as the "thinker of Bayreuth" and remarked on the close relationship between "the Bayreuth Kulturkreis and Hitler's Feople's Movement." 60 But for most Nazis, Wagner's works of art and even Chamberlain's turgid rhetoric were foreign, little studied artifacts, although many collections of citations were reprinted. On the other hand, the Bayreuth Idea and Chamberlain did exercise a profound influence on the chitef Nazi theoretician, Alfred Rosenberg. ${ }^{61}$

Soon after Chamberlain's death Rosenberg published his Houston Stewart Chamberlain als Verklhder und Bergrilnder einer deutschen Zukunft. Rosenberg freely appropriated Chamberlain. To read this book is to reread a great part of Chamberlain's books. However, Rosenberg really believed in what he quoted and the conclusions which followed. Rosenberg utilized the most reifled, emotional, even paranoic conments of Chamber-

stayed at the Bechstein's next to Wahnfried. He further stated Cosima used to call and write him to attend the Festspiele when he could not attend. Further, he stated "It's Cosima Wagner's merit to have created the Iink between Bayreuth and National Socialism." Ibid., p. 284. However, during the entire period of the 1920 's, Cosima was quite old, sick, and increasingly disoriented. She was kept in her room, and had to be tended constantly. This senile state continued until her death. Schllier stated Cosima never met Hitler, Der Bayreuther Kreis, pp. 84-85. And it was reported. that after Chamberlain's death the 92 year-old Cosima claimed that he still spoke to her "in the quiet of her soul." "Houston Stewart Chamberlain: Prophet of Bayreuth," p. 533, and Houston Stewart Chamberlain, Briefwechsel introduction, p. 12.

${ }^{60}$ Joseph Goebbels, Kampf um Berlin, vol. 1, p. 216, quoted in Blliow, Adolf Hitler und der Bayreuther Kulturkreis, p. 7.

${ }^{61}$ Some authors use the title "philosopher" in regard to kicsenberg; I think "theoretician" perhaps is more accurate. The full history of Rosenberg and particularly his relationship to Chamberlain has not been explored. 
lain in this book, and did a quite admirable job of cataloguing the writer's ideas by genera. His book leaves out only such contrary material as Chamberlain's cosmopolitan views of French literature, and such fetishes as his insistence upon Christianity, and the primacy of individual fatth.

Rosenberg related Chamberlain had been asked by an American during: the World War how long the war could last. Chamberlain, confldent in the German people and the rightness of their cause answered, "A hundred years; perhaps two hundred years."62 Rosenberg noted Chamberlain's opposition to the day's "enerijes" of' Germany: finance capitalism, the "Dawes-Diktat," the Western intent to turn Germany into a "colony of slaves," the destructive talk of "pan-Europe" cooperation, the introduction of "American--Judaic music," prostitution, "pornographic newspapers," "negro dancing." 63

Rosenberg repeated Chamberlain's criticisms of the World War, trat Whille the German front had had a "herrliches Fihrergeschlecht," in the rear, domestic areas, the Volk vias leaderless, without the will to win. He interpreted the "Seher von Bayreuth" as having outlined the German struggle for Soul and for the Ideal. 64 Chamberlain's "Weg zum Deut.schitum" should then be a valuable lesson for the future. ${ }^{65}$ Rosenberg; also

62 Alfred Rosenberg, Houston Stewart Chamberlain als Verklunder und Begrunder einer deutschen 7ukunft, (Munich, Bruckmann, 1927) p. 7.

$6.3_{\text {Ibid. , p. } 13 .}$

64 Ibid., p. 14.

${ }^{65}$ Rosenberg even intimated trat rad Chamberlain been required to go to the colonies as a farmer instead of finding his path to Germany, he mighit have comitted sulcide. Ibid., p. 18. 
continued Chamberlain's attacks on such contemporary "evils," as the Monism of Haeckel and Ostwald, "astrologische 'Wissenschaft" and the pessimistic work of Oswald Spengler. ${ }^{66}$ Rosenberg added a dimension to Chamberlain's formulation of race, includirg Slavs now under the rubic "Aryan." For Rosenberg the Germans were the "Slavokeltogermanen" creators of a future world. 67

For Rosenberg, the Foundations was even more important in 1927 than When it was first written. 68 The "flag of German consciousness" had been passed from Martin Luther to Friedrich the Great, to Bismarck and Moltke, and to Chamberlain. Now Rosenberg, said the inheritor of German tradition would be the "Man with the heart of a Iion": i.e., Adolf Fitler. 69

In criticising America, Rosenberg could not quite decide whether the institution of the Arierican Presidency or the contemporary gangsters of the 1920's were worse. But he was certain that the American Congress was the worse government west of Russia. 70 The Germans, however, for Fosenberg, in times of crisis would turn to "natural" forms of government. This would have to be a strong leadership which alone could protect German freedoms. 71 Rosenberg summarized Chamberlain's oeuvre, stressing, the theme of two Germianies, which consisted of $80 \%$ true Germans and $20 \%$ irrernediably cormpted Germans. Further, Rosenberg stressed not simply

$$
\begin{aligned}
& { }^{66} \text { Ibid., p. } 22 . \\
& 67_{\text {Ibid., p. } 23 .} \\
& 68_{\text {Ibid., p. } 29 .} \\
& 69_{\text {Ibid., p. } 35 .} \\
& 70_{\text {Ibid., p. } 42 .} \\
& 71_{\text {Ibid., p. }} 52 .
\end{aligned}
$$


racial but Volk definitions for delineating true from Jewish-Marxist corrupted fermans. 72 For the proper continuing interpretations of Chamberlain, Rosenberg recommended V8lkischer Beobachter. This would warn readers against Zionism, Freemasonry, Communism, International Finance, etc. 73 He noted with some accuracy that Chamberlain's Fourdations should be read as a work of art, that Chamberlain dealt with ideas just as a painter might wield a brush, by painting around a theme. 74 And Rosenberg looked forward to the time when he hoped Chamberlain's thought would be placed in German textbooks, when history and theology would be interpreted according to Chamberlain, when the existing "urdeutschen demokratischen Systeme" would be replaced by a real German national state headed by a genuine leader. 75 Rosenberg stated that the universal man in 1700 had been Ieibniz, in 1800 it had been Goethe, and in 1900 it surely had been Chamberlain. The totality of Chemberlain's work embodied the Aryan reality, and pointed the way toward a new future. 76 However, in his own Der Mythus des 20. Jahrhunderts (1930) Rosenberg extended Chamberlain's methodology to the present. His murky, nearly unintelligible book sold well in the Third Reich, but was really

$$
\begin{aligned}
& 72 \text { Ibid., pp. } 72-74 . \\
& 73_{\text {Ibid. , p. } 78 .} \\
& 74 \text { Ibid., p. } 96 . \\
& 75_{\text {Ibid. , p. } 98 .}
\end{aligned}
$$

76 Toid., pp. 98-99. The last section of Rosenberg's book was devoted to a quite good selection of Chamberlain citations organized sensibly in these six categories: (1) personality and generalities, (2) race, people and state, (3) art and artists, (4) religion and churches, (5) man and publications, and (6) criticism of consciousness and science. Altogether, Rosenberg's was one of the best summaries of Chamberlain available. It was valuable as well for later writers in the Nazi period. Ibid., pp. 103-128. 
only a coffee-table sort of book even Hitler joked about. 77

In 1934, aiter the Nazi "seizure of power," the authoritative Nazi journal, the Nationalsozialistische Monatshefte, printed an article on Njetzsche and Chamberlain. In it the two men were claimed as great sources for National Socialism, but there was criticism for the efforts of many contemporaries who were approcriating German history in the search for Nazi precursors. With some petulance the article stated that Nazism was on the contrary a new movement, grateful for ger:eral guideljnes handed down by great Germans of the past, but claiming its own distinctive Weltanschauung, its own direction for the future. Thus, National Socialism's way tc the future would be incredibly difficult, without a clear guideline. 78 "Chamberlain and Nietzsche were children of their times" and, as such, made mistakes as well; for an understanding, of the inner, true, relationship of these men to the $1930^{\prime} \mathrm{s}$, one was advised to read Hitler's Mein Kampf and Rosenberg's Mythus. The real message of such great precur'sor's as Nietzsche and Chamberlain was their. injunction: "realize your'self." With this insight, many writers from earlier tines could be, and were, identified with the new Germany. 79 Since the Nazi future had not yet keen complete?y achieved, all such precursing literary influences should be accorded positions in the pantheon of Germanic heroes, but should not be absolutely deified as

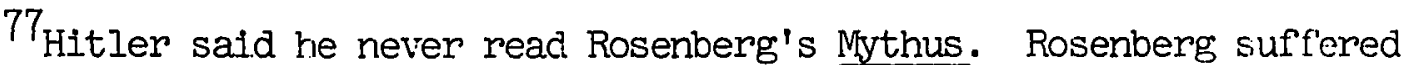
because he never could relate contemporary needs to his various jobs in precise, clear terms. He was thus ineffective as a bureaucrat in the Third Reich, and remained a singular, contradictory Nazi "thinker."

78Fritz Peudert, "Chamberlain und Nietzsche," Nationalsozialistische Monatshefte, vol. 49 (April, 1934), p. 305.

79 Tbid., p. 305. 
National Socialists. Clearly, this final apotheosis was to be entirely reserved for the 20th century's own leaders -- for Hitler and ris cohort.s. Chamberlain's legacy was, of course, useful to the Nazis largely without alteration. For instance, the 1928 publication of his scientific speculations by his friend Uexklli provided an opportunity to update Chamberlain's criticisms. Uexklll noted the current political "confusion" mandated that Germans gain a clear understanding of Chamberlain's "pathfinding ideas" in biology as well as in culture and history. 80 Mere biology, with its counterpart of mere contemporary Weimar republicanism, was simply inadequate: what had Gestalt was life; life was Gestalt. 81 Thus, Chamberlain's views were presented to the laity, which accordingly might then expect to comprehend the deeper meanings of true, German science. 82 As a mixture of Goethean speculations about nature, of Indian and Kantian ideas, it was hoped Cramberlain's notions would enrich the "geistigen Eesitz" of mankind, deal a death-blow to empiricist Evolutionism, and salvage true German metaphysics and art. 83 The result of his scientific reformulations was this view of life as Gestalt within which racism, Wagnerism, and Deutschtum provided the linking mediators. The whole was termed Weltanschauung. 84

${ }^{80}$ Chamberlain, Natur und Leben, p. 80.

${ }^{81}$ Ibid., introduction, p. 9.

82 Ibid., introduction, p. 16.

${ }^{83}$ Ibj.d., section of the book reprinted from a Chamberlain letiter to Baroness Ehrenfels, October 22-23, 1896, p. 103.

${ }^{84}$ Ibid., section of the book reprinted from a. Chamberlain manuscript of 1896 on the Lebenslehre, pp. 118-119. As mentioned in chapter VI, this was one of the basis for the "Gierman science" movement sponsored by the Nazis. 
Less useful for the essentially non-religiods Nazi movement were Chamberlain's theological writings. The German Christian movement under the Third Reich had increasingly to relinquish Chamberlain's personalized God for a collective, racial God. Also, such writers as Rosenberg had to revise Chamberlain's ideas of race "to make them more uncompromising." This hardening of Chamberlain's racist thought pressed on his original aesthetic formulations under National Socialism. 85 Perhaps with Chamberlain's last theological work, the Mensch urd Gott (1921) there was visib].e a reemphasis on simply Christianity. This was the culmination of mysticism in Chamberlain, who paradoxically always had insisted he was not a mystic. In the book he praised an Aryan religion beyond specific individuals, beyond doctrines, oriented simply toward a future purity of Aryan Weltanschauung. He insisted on the divine importance of every hair on the human head. 86 His formulations on theology thus seemed to have increasingly become divorced from the unpleasant republican realities of the 1920's. 87 This interpretation, at least, was expressed by a religious writer in the Nazi era who praised Chamberlain only as a theological writer. It was stated many of the day's Nazi "Religionsphilosophen"

85"Houston Stewart Chamberlain: Prophet of Bayreuth," pp. 352-353.

86 This was mentioned in a revisionist book on Germany which oddly neglects the totality of Chamberlain's works and influence, but does state this theological concern. George Bailey, Germans: Biography of an Obsession (New York: Avon Books, 1972) p. 219.

87 This has been interpreted in numerous ways. For instance, Mosse stated the neo-Kantians separated the "Ding an Sich" from a grouriding in phenomene, resulting in a spiritualization of will. This seems a valid statement particularly about Charnberiain's later theological speculations. Mosse, The Crisis of German Ideology, p. 94. 
could leam from Chamberlain's views on the primacy of faith. ${ }^{88}$

$88_{\text {rinis was the interpretation of at least one writer in the Nazi }}$ era who praised Chamberlain only as a theological writer. Further, it was inferred this limited aspect of Chamberlain's thought should be the main model in the Third Reich. Gertrud Frischmuth, Houston Stewart Chamberlain als Christ (Gltersiloh: C. Bertelsmann, 1937), p. 25. 


\section{CHAPTER X}

APOCALYPSE AND PHOENIX

While Chamberlain and the Bayreuth Idea thus were taken as simplified dogma in the Third Reich, both Wagner's and Chamberlain's criticisms of their times had been complex, not simple. The evolution of their ideas had mirrored the day's aesthetic criticism and partaken of the day's prejudices. Their attacks on bourgeois values were hardly original, and were often less volatile than the views of men such as Gobineau, Renan, Taine, Lagarde and Iangbehn. Their actual output usually remained primarily aesthetic, demonstrating an ambiguous cosmopolitanism and yet provincialism, individualism and yet racism, spiritualism and statism. Their attempts to unite man's disparate views were thus kindred to the phenomenon of alienated intellectuals.

From the diligent work of Wahnfried, Wagner came to be known as; the prophet, and Chamberlain the John the Baptist of the Hitler movement. To many of his contemporaries, Hitler was the Messiah souplnt by these earlier men. Indeed, throughout the twelve year Reich this was the fate of these two men's reputations in Germany. With the letters of Chamberlain to Hitler, the Führer was seen anointed as thit: "Savior" of Germanism.

Outside Germany during the $1930^{\prime}$ 's there was a partial rehabilitation of Chamberlain's reputation. 1 Insofar as Germany's burden for'

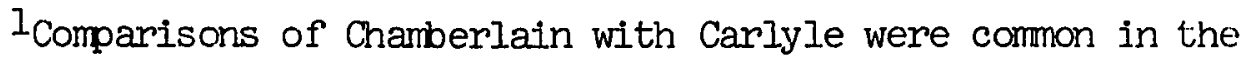
Nazi era. This comparison was made in England. The British 
the World War was concerned, and as regards Chamberlain's anti-Semitism, England, at least, appeared somewhat furgiving. 2 International friends of Wahnfried such as Lord Redesdale again made the "pilgrimage" to Bayreuth, and associated with Hitler and the leadership of the new government. 3

The last year of peace in Europe, 1939, saw the death of the last of the Bayreuth Old-Guard, Hans von Wolzogen. A further indication

professor H. J. C. Grierson delivered a lecture series on this topic in 1930 and his remarks were republished in book form. He noted that mass society in the twentieth century had seemed to fulfill the worst fears of Carlyle, and this was evidenced by Catholic, Communist and Fascist successes. "Freedom of thought and of the Press have a short and precarious history. Men desire to believe: hero-worship is not only an instinct, it is a need of the human spirit." H. J. C. Grierson, Carlyle \& Hitler: The Adamson Lecture at the University of Manchester, December 1930, with additions and modifications by the author

(Cambridge: At The University Press, 1933), p. 27. In a note inserted after the Nazi seizure of power the author defended his earlier enthusiasm for Carly le with the reasonable observation, "If Ruskin led to Oscar Wilde, as a recent French critic declares, Carlyle led direct to Nietzsche." Grierson, Carlyle \& Hitler, p. 47. With a sensibility akin to Chamberlain's aesthetic predilections, Grierson argued the Zeitgeist seen by Carlyle was increasingly manifest in the twentieth century; the failure of men to act on Carlyle's insights had in part led to the dominance of democracy, World War one, and the day's economic and dictatorial events. Further, Grierson suggested parallels existed between Ienin, Stalin, Mussolini, Hitler, and even Roosevelt, Mosley and Cripps in their shared views of democracy, constitutional government and liberty; all for him represented the reaction to moderm decay. Grierson, Carly le \& Hitler, p. 62. This literary abnegation of Realpolitik in the interwar period was as well similar to the spirit. of such earlier Kulturkritiks as Chamberlain.

2Holmes, "Houston Stewart Chamberlain in Great Britain," p. 36.

3Lord Redesdale's family, the Mitfords, had a remarkable recond in political and aesthetic matters. Nancy Mitford, oldest of six daughters of the "eccentric" Lord Redesdale, was a writer. Unity Mitford fell in love with Hitler and shot herself. Heritage of Fire, pp. 91-94. Di ane Mitford married the British fascist Sir Oswald Mosley, Debo Mitford became Duchess of Devonshire, Jessica Mitford turned communist, went to Spain during the Civil War with a cousin of Sir Winston Churchill, and was an active political and publishing figure in America in the 1960 ':.;. "Shrieking all the way," review of Nancy Mitford: A Memoir, by llarolid Acton, Newsweek (May 3, 1976), pp. 91-94. The incidents at Bayreuth in 
of the change in the times was the need for a press release by the Nazl government explaining that the Berlin Chamberlainstrasse was named for Houston Stewart, not for Arthur Neville Chamberlain (18691940). 4 Republications and exegeses of Chamberlain's works continued through the Second World War in Germany, and scholars in Bayreuth continued to deepen the Bayreuth Idea. 5

Though Bayreuth was much more clearly politicised than it had been in the First World War, to many of the participants it seemed far removed from the day's political events. It was decided to keep the Festspielhaus in operation during the war to help strengthen morale. After 1939 Parsifal was dropped from the repertoire (perhaps due to its too-Christian elements), and the Ring was only performed through 1942. Only Die Meistersinger, Wagner's only comic opera, and the ambiguous vehicle for national as well as purely artistic inspiration, was continued until the end of 1944. With the declaration of total war in December, 1944, even this last Bayreuth effort was ended. While many adherents of the Bayreuth Idea and fascism in general had hoped for a truly revolutionary praxis, their hopes were in fact dashed. 'The students, the artists, the intellectuals who had sought an aesthetic rebirth in National Socialism met quite conservative Nazi policies as

the 1930's are further discussed in Friedelind Wagner, Heritage of Fire, pp. 205-206.

4Viereck, Metapolitics, p. 38.

5Publications about Wagnerism continued to be issued from Bayreuth during the war, and in 1943 there was a large festival celebrating Wagner's Meistersinger. The opera was given 16 times for Hitler, other top NazIs, and nearly 300,000 soldiers and workers. 
Hitler consolidated his hold. Alfred Baeumler stated that with the completion of Gleichschaltung the era of "Hegelian striving" was at an end. ${ }^{6}$ Leadership by an elite and rigid insistence on social conformity stamped out the leftwing aspirations of many "third force" intellectuals. National Socialism replaced these yearnings with saccharine, nearly bourgeois sentimentality and social conservatism under the guise of revolutionary anti-Bolshevism.7 Even the cultural underpinnings for which aesthetes had worked were quite harshly treated under the Nazis. Ironically, Wagner and even Chamberlain had both shared affinities with this leftist, revolutionary aestheticism; but with apotheosis under the Nazis they themselves became all-encompassing symbols under which dissent was quashed.

Bayreuth did survive 1945 as a focal point for art. The Bayreuth Idea was, to be sure, militarily defeated, and exists as a problem only to be debated, with few remaining adherents. Winifred Wagner's close association with Hitler was a major difficulty, however. Having, been named a war criminal, she was placed with a group of major collaborators by a Denazification court. She was convicted of "turning the Wagner music festivals at Bayreuth into a 'mecca for Nazi propaganda.'"

This "War Festival" was described in a specially-printed booklet, Rifchard Wagner und seine Meistersinger (1943), unavailable in America through Inter-library loan. Quoted from Raphael, Richard Wagner, p. 133.

6 Der Bayreuther Kreis, pp. 116-119.

7Music education as well as other academic pursuits suffered a dramatic decline in the Third Reich. More useful to the new ruler's were physical training and group activities stressing leader-follower relationships. An excellent short summary of the problems of music in the Nazi era is Richard Grunberger, The 12-Year Reich: A Social History of Nazi Germany, 1933-1945 (New York: Ballantine Books, 1971), pp. $449-465$. 
Her sentence by a tribunal at Bayreuth was for 450 days hard labor, and the confiscation of $60 \%$ of her property. ${ }^{8}$ Penalties were somewhat lessened on appeal, and Winifred worked out her sentence unflinchingly, earning the respect of many Germans. She remained Führertreu and only by releasing her personal ownership of the Festspielhaus to her sons Wieland (1917-1966) and Wolfgang (b.1919) was a reopening of the Festspiele possible. She remains prominent among the old-guard Wagnerites, and has yielded none of her devotion to the Bayreuth Idea and to Adolf Hitler.9 In postwar intervlews she affirmed her prewar views and wished she could yet again see the "good uncle from Bayreuth" visit Wahnfried. After all, Hitler had been kind to her. ${ }^{10}$

When the first postwar performances were finally to be given in 1951, Winifred's sons made a difficult choice in breaking new artistic ground. They could have opted for the traditional Wagnerian schema of Cosima's era, before the Hitlerzeit. However, they took seriously

OWinifred Wagner: Guilty," Newsweek, vol. 30 (July 14, 1947),
p. 44.

9 After nearly 30 years of silence, Winifred allowed a film to be made of her, which defended her views on Hitler. This amazing artif'act. was produced in 1975, entitled "Winifred Wagner and the History of Hau:3 Wannfried, 1914-1975" which has perhaps not made its way yet to America. Quoted in "Good Old Adolf," Newsweek (August 18, 1975), p. 33. More detail about this quite odd work is Wolf Donner, "Winifred, Waknfried, Wagner; A Silence is Broken in Bayreuth," Encounter (December, 1975), pp. 32-37.

10This has been a consistent aspect of Winifred's Weltanschaluune, cited and commented on in Herzstein, "The Wagnerian Ethos in Cerman History," p. 362. 
Wagner's famous injunction, "Kinder schafft neues!"ll They utilized the stage theory of a friend of Chamberlain, Adolph Appia, whose original notions had been quite rudely rejected by Cosima Wagner in 1896.12

Postwar Bayreuth has continued to be most "revolutionary" in interpreting the Meister's works. The great revival of interest in discredited Bayreuth owes much to an emphasis on psychological inter pretations of Wagner, and to the down-playing of his racism. 13 The performances have utilized laser beams, sparse sets, and some revision of Wagner's librettos. Much of what Wagner had originally desired was not technically feasible in his century, and in a quite credible

11This has been the subject of several books already cited, and is present as well in the booklet printed for the 1976 Seattle Opera Association's Ring presentation, "Program for 'Der Ring des Niebelungen, '" special issue published by Encore Magazine of the Arts (July 1976) which featured a laudatory article by William Curren, "Bayreuth - The First Hundred Years," pp. 6-8, 23 and 29.

12 Appia had written an article, "Notes zur L'Anneau du Nibelungen," in which he advocated a quite useful combination of lighting and stage effects. This entire question was taken up only after World War Two by Bayreuth, although Siegfried and his son Wleland had experimented with Appia's innovations. Cosima's original comment, however, was illustrative of her entire rule at Bayreuth. She said that Appia did not realize the Ring had been performed in 1876 by the Meister himself with her in attendance-as a result only replication, not innovation, was possible. Cosima to Chamberlain, May 13, 1896, Briefwechsel, pp. 46t466. Appla remains an important authority in modern stage craft today even beyond Wagnerian opera productions. His relationship with Chamberlain was the subject of a recent article, Walther R. Vollbach, "Adolph, Appia und Houston Stewart Chamberlain," Die Musik Forschung, No. $4(1966)$, unavailable through University Inter-Iibrary Loan. fn., p. 359.

13Gutman, Richard Wagner: The Man, His Mind, and His Music, 
fashion has been realized only with the 'new,' postwar Bayreuth. Particularly, Wagner's drive toward the invisible stage as well as the invisible orchestra have been today achieved. Wagner's other works such as Parsifal have been less reworked, and the favorite Die Meistersinger has been presented almost as it was a century ago. Through emphasizing the humanistic aspects of Wagner it appears likely the Meister's works will continue to enjoy a great popularity--shorn as they are of the Bayreuth Idea. 14

But Richard Wagner was above all an artist. His evolution needs to be viewed through his orientation to aesthetics. Chamberlain, by contrast, instead of being an original thinker or even an innovative interpreter of art, was first a commentator in his own day. His concern was in a very real sense (despite his occasional disclaimers) to direct his contemporaries toward concrete goals. Though he never was clear on the division between his cultural aspirations and his practical values, he primarily viewed himself as a man for his own times. As Herzstein

14 Other interpretations of Wagner's works have ranged from recent performances in Cassel where the Walkuries wore leather tights and rexle motorcycles, to the 1976 Bayreuth Ring. This latter event featured Wotan as a Victorian dandy, the Rhine maidens as Soho tarts, and a backdrop of modern industrial blight. Fred Calland, "All Things Considered," National Public Radio (August 13, 1976). More traditional performances have been given in places such as Seattle, Washington which have stressed Wagner's literary and psychological talents. Along these lines, a translator of an English version of the Ring, Andrew Porter, wrote "Wagner And 'The Fing'" in the Seattle Opera Association's program, Wagner's The Ring of the Nibelung (July 1975), pp. 18-19. Additionally, this organization sponsored the distribution of a Jungian psychologist's interpretation of Wagner, Franz E. Winckler, For Freedom Destined: Mysteries of Man's Evolution in Wagner's Rine: Geeras and Parsifal (Garden City, New York: Waldorff Press, 1974). 
asserted, Chamberlain was essentially an optimist who needed great symbols to sustain his faith. After 1870 he found Germanic culture, after 1914 the German army, and after 1923 Hitler. While he was "basically a good if confused man, Houston Stewart Chamberlain symbolized a century which had been forced to choose between Kant and Bismarck." I5 Chamberlain was one of the first men of thought to be taken with National Socialism, but it was not with the vitality of a young man--as when he had earlier hailed Wilhelmine Germany and Bayreuth-but as an old, quite ill and tired man, that he embraced Hitler. 16

Schüler concluded that where the Bayreuth Kreis went wrong was with the conglomeration of all ideas under the totalitarian Bayreuth symbol. This tight, national scheme was easily manipulated by men less artistic, less idealistic. Thus where the ideology erred was with an

. . unrestrained boistrous speculative drive, an uncontrolled drive toward romanticization and mystification. Artistic endeavors belong to the great and indivisible entirety of mankind. As a foundation of metaphysical theories and political doctrines it is unsuitable. 17

This tentative conclusion, however, defending as it does the transcendental nature of art, ignores the interaction of aesthetic and social values. There remain considerable quantities of evidence, as shown in this study, which may lead to quite contradictory conclusions about the lives and works of such great artists as Richard Wagner and even about such notorious popularizers as Houston Stewart Chamberlain. The very existence of the Bayreuth KuIturkreis for a century presents a ${ }^{15}$ Herzstein, "The Wagnerian Ethos in German History," p. 362. ${ }^{16}$ Ibid., p. $323 . \quad 17$ Der Bayreuther Kreis, p. 278. 
focal point for an ongoing investigation of society. This heavily documented institution implicitly denied any "Kantian" respect for human variation.

George Mosse concluded one of his books with the observation that the predicament of intellectuals in the modern age has led to a defensive separation of aesthetic from practical concerns. He noted the linking-as did Schtllermof the ldeal and the real by twentieth century intellectuals to be in general a failure. The Bayreuth KulturKreis may be sald to be such a fallure. But the Krels attempted in general to set boundaries for art, to establish rational goals for man (as they percelved them), to make sense of the human condition. This drive toward wholeness, toward integration of allenated interests, Itself became Increasingly divorced, not synonomous, with rationality and many accepted human values. As Mosse concluded, other intellectuals not of Chamberlain's particular political orientation may have been equally "rootless" but seem to have made wiser Judgments. Thomas Mann, Andre Glde, Romain Rolland and Julien Benda did indeed work for realizable political goals opposed to Nazism and the Bayreuth Idea. However, In order to do this, these "good Europeans" tended to separate their aesthetics from their politics: the integrative function of art, religion, of philosophy itself was sacrificed. ${ }^{18}$

Even with our own day, man's yearning for overcoming alienation via quite demonstrable symbolism has not ended. In a less "total" fashion this continues in the largely aesthetic vogue with the Meister's operas: on a more concrete level it may be central to the goals of many

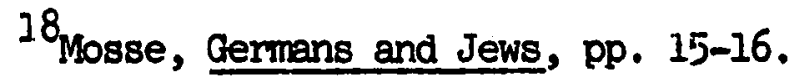


conternorary sccial and political movements. The unifying function of Bayreuth has found many imitators, since it was itself not totally original, but shared in the reification of ideas in modern historical settings. It may reasonably be anticipated that even the failure of the Bayreuth Idea may be co-opted in future drives toward spiritual and social unity. The great power of such notions continues in a fascinating parallel to the most central Western problems of philosophy, religion and art in a veritable ewige wiederkehr. On this level it is ironic that 1976 begins the second hundred years of artistic ceremony on the Bayreuth Festspielhugel. Bereft of the Kreis ideology, the centenary of Wagner's Festspiele continues to raise, not to resolve, questions of enduring human interest. 


\section{A SELECTED BIBLTOGRAPHY}

Baeumler, Alfred. Weltdemokratie und Nationalsozialismus: Dié Neue Ordinung Europas Als Geschichtsphilosophisches Problem. Berlin: Duncker und Humblot, 1943.

Barzun, Jacques. Darwin, Marx, Wagner: Critique of A Heritage. New York: Anchor Books, 1941; reprint ed., New York: Anchor Books, 1958.

- Race: A Study in Superstition. New York: Harper \& Row, 1937; revised ed., New York: Harper Torchbooks, 1965.

Bein, Alexander. "Der Moderne Antisemitisrmus und seine Bedeutung für die Judenfrage": "Antisemitismus" a la Wort und Begriff." Vierteljahrshefte fur Zeitgeschichte 6 jahrg. (1958): 340-360.

Biddiss, Michael D. "Houston Stewart Chamberlain: Prophet of Teutonism." History Today (London) January 1969. pp. 10-1.7.

Blissett, W. "D. H. Lawrence, D'Annunzio, Wagner." "Wisconsin Studies in Contemporary Literature 7 (Winter 1966): 21-46.

Bluel, Hans Peter and Klinnert, Frnst. Deutsche Studenten auf dem Weg ins Dritte Reich. Ideologien, Programme, Akt1onen 1918-1935. Gutersloh: Siegoert Mohn, 1967.

Breitenstein, Desiderius. Houston Stewart Chamberlain: Ein Wegbereiter Des Rassischen Weltbildes. Warendorf: J. Schnellsche, 1936.

Brockway, Wallace and Weinstock, Herbert. Men of Music: Their Lives;, Times, and Achievements. New York: Simon and Schuster, 1950.

Billow, Paul. Adolf Hitler und der Bayruether Kulturkreis. Aus Deutschlands Werden Series, Heft 9. Leipzig: Gustav Schloessmann, n.d. late $1930^{\top} \mathrm{s}$.

- Bayreuth: Die Stadt der Wagner-Festspiele. Leipzig: Bibllographisches Institut, 1936.

Carmpbe11, 'T. Moody. "Nietzsche-Wagner to January, 1872." Modern: Language Quarterly 56 (January 1941): 544-577. 
Cassirer, Ernst. The Myth of The State. New Haven: Yale University

Press, 1946; reprint ed., New Haven: Yale University Press, 1961.

Chamberlain (Horst), Anna. Meine Erinnerungen an Houston Stewart Chamberlain. Munich: Oskar Beck, 1923.

Chamberlain, Basil Hall ard Hearn, Lafcadio. Letters From Basil Hall Chamberlain to Lafcadio Hearn. Compiled by Koizumi, Dazuo. Tokyo: The Hokuseido Press, 1936.

- More Letters From Basil Hall Chamberlain to Lafcadio Hearn. Complied by Koizumi, Dazuo. Tokyo: The Hokuseido Press, 1937.

Chamkerlain, Houston Stewart. Eine Auswahl aus seinen Briefen. Edited by Hardy L. Schmidt. Delhagen and Klaffing's Deutsche Iesebogen series, no. 220. Bielefeld: Delhagen and Klafing, 1937.

- "Brief llber Heinrich ileine." Deutschlands Emeuerung: Monatschrift fur das Deutsche Volk. Vol. 9, December, 1917. pp. 819-824.

- Briefe 1882-1925 und Briefwechsel mit Kaiser Wilhelm II. Ed. Paul Pretzsch, 2 Vols. Munich: Bruckmann, 1928.

- Chamberlain der Seher des Dritten Reiches: das Vermähchtnis Houston Stewart Chamberlain an das Deutsche Volk. Ed. Georg Schott. 4th Ed. Munich: Bruckmann, 1933; Munich: Bruckmann, 1941.

and Wagner, Cosima. Cosima Wagner und Houston Stewart Chamberlain im Briefwechsel 1888-1908. Ed. Paul Pretzsch. Leipzig: Reclam, 1934.

- "Deutsche Weltanschauung." Deutschlands Emelerung: Monatschrift fulr das Deutsche Volk. Vol. 1, April, 1917. pp. 6-20.

- Deutsches Wesen. Munich: Bruckmann, 1916.

- Deutschland-England, aus den Schriften zum Weltkrieg. 4th. Ed. Munich: Bruckmann, 1939; Munich: Bruckmann, 1943.

- Drei Vorworte. Munich: Bruckmann, 1923.

- England and Germany. With "Prefatory remarks for reiders in neutral countries," [ no location or publisher ] 1915. 
- Die Ersten Zwanzig Jahre Der Bayreuther Bulhnenfestspiele. Bayreuth: Lorenz Elwanger, 1896 [ repr. of "1876-1896. Dle ersten zwanzig Jahre der Bayreuther Bllhnenfestspiele." Bayreuther Blthter, 19 Jahrg. 1896 ].

and Poske, Fredrich. Heinrich von Stein und seine Weltanschauung; Nebst Heinrich von Steins "Vermachtnis". 2nd. ed. Munich and Letpzig: Milizex, 1905.

- Goethe, 4th ed. Munich: Bruckmann, 1912; Munich: Bruckmann, 1923.

. "H. St. Chamberlains Briefe an Schemann." Letters from the years 1888, 1893 and 1894. Introduction by Bertha Schemann. Deutschlands Erneuerung: Monatschrift filr das deutsche Volk. Heft 6, June, 1938. pp. 281-287.

- "How Richard Wagner wrote his operas." The Ladies Home Journal (Philadelphia) November, 1898.

- Immanuel Kant: A Study And A Comparison With Goethe, Ieonardo Da Vinci, Bmuno, Plato and Descarte. Translated by Lord Redesdale, G. C. V. O., K. B. C. Introduction by Lord Redesdale. Munich: Bruckmann, 1905; English ed. London: John Lane, The Bodley Head, 1914.

1902 "'Katholische' Universitaten." Die Fackel (Vienna) Januar'y,

- Lebenswege meines Denkens. Munich: Bruckmann, 1919.

- Mein Weg Nach Bayreuth. Introduction by Paul Blllow, "Houston Stewart Chamberlain und der Bayreuther Kulturkreis". [repr. from his Lebenswege meines Denkens; no location or publisher ] 1937.

- Mensch und Gott. Betrachtungen tber Religion und. Christentum. Munich: Bruckmann, 1922.

- Natur und Leben. Ed. Jacob von Uexkllil. Munich: Bruckmann, 1928.

- "The personal side of Richard Wagner." The Ladies Home Journal (Philadelphia) October, 1898.

- Rasse und Personlichkei.t. 3rd. ed. Munich: Bruckmenn, 1925; Munich: Bruckmann, 1937.

- Richard Wagner. Translated by G. Ainslie Hight. Revised by the author. Munich: Bruckmann, 1896; English ed. Munics: Bruckmann, 1897. 
"Der voraussetzunglose Mommsen." Die Fackel (Vienna) 87, November, 1901. pp. 1-13.

- The Wagnerian Drama: An Attempt to Inspire a Better Appreciation of Wagner as a Dramatic Poet. Leipzig: Breitkopf und Hirrte1, 1892; English ed. London: John Lane, The Bodley Head, 1915.

Charlton, D. G. Secular Religions in France 1815-1870. London: Oxford University Press, 1963.

"The Christianization of Nietzsche's 'Blond Beast."" Current Literature, September 1911, pp. 289-294.

Clark, Kenneth. The Romantic Rebellion; Romantic versus Classic Art. New York: Harper \& Row, Publishers, 1973.

Comas, Juan. Racial Myths, The Race Question In Modern Science. 2nd. ed. Paris: UNESCO, 1951.

Conkin, Paul K. and Stromberg, Roland N. The Heritage And Challenge Of History. New York: Dodd, Mead \& Company, 1972.

"Coppernicus, Kant, Rosenburg." The Spectator, 3 March, 1939, p. 35.

Curren, William. "Bayreuth - The First Hundred Years." In "Program tor 'Der Ring des Niebelungen, ' Encore Magazine of the Arts (July 1976) pp. 6-8, 23 and 29.

Daim, Wilfred. Der Mann, Der Hitler Die Ideen Gab; Von den religiüsen Verirmungen eines Sektierers zum Rassenwahn des Diktators. Munich: Isar, 1958.

Deverall, Richard. "Racism." Catholic World, January 1939, pp. 398-404.

Dippel, Martin. Houston Stewart Chamberlain. Reihe Kllnder und KḦmpfer series. Munich: Deutscher Volksverlag, 1938.

Donner, Wolf. "Winifred, Wahnfried, Wagner; A Silence is Broken in Bayreuth." Encounter, December, 1975, pp. 32-37.

Dorring, Dskar. Ein Deutscher namens Chamberlain: sein Lebensbild nach seinen ej.genen Worten. Aus deutschen Schriftum und deutscher Kultur series 549. Langensalza: J. Beltz, 1937.

Fackenheim, Emil L. "Kant and Judaism." Commentary, December, 1973, pp. $460-467$. 
Fleld, Geoffrey G. "Antisemitism and Weltpolitik." Yearbook XVII: Publications of the Leo Baeck Institute. London: Secker \& Warburg, 1973. pp. 65-91.

- "Houston Stewart Chamberlain: Prophet of Bayreuth." Ph.D. dissertation, Columbia University, 1972.

Fischer, Fritz. Germany's Aims in the First World War. Introduction by Hajo Holborm and James Joll. Dusseldorf: Droste Verlag, 1961; New York: W. W. Norton \& Co., Inc., 1967.

Forrest, G. W., C. I. E. Life of Field-Marshal Sir Neville Chamberlain, G. C. B., G. C. S. I. Edinburgh and London: William Blackwood and Sons, 1909.

Frischmuth, Gertrud. Houston Stewart Chamberlain als Christ. Gutersloh: C. Bertelsmann, 1937.

Freed, Ian. "The end of the Tether." The Twentieth Century, January, 1952, pp. 71-81.

Geismar, Berta. The Baton And The Jackboot: Recollections of Musical Iife. Iondon: Hamish Hamilton, 1944.

Geprdgss, Adolf. Germanentum und Christentum bei Houston Stewart Chamberlain. Gobttingen: Bandenhoeck and Ruprecht, 1938.

Giddings, Robert. "Wagner and the Revolutionaries." Music and Letters 45 \#4 (October 1964): 348-358.

Gobineau, Comte Arthur de. Versuch Uber die Ungleichheit der Menschenracen. Translated by Ludwig Schemann. 4 vols., 2nd ed. Stuttgart: Fr. Fromann, 1902.

Goldmann, Iucien. Immanuel Kant. Zulrich: Europa-Verlag, 1945; enlarged and revised ed. Iondon: NLB, 1971.

"Good Old Adolf." Review of film "Winifred Wagner and the History of Haus Wahnfried, 1914-1975." Newsweek, 18 August, 1975, p. 33.

Grabs, Rudolf. Paul de Lagarde und H. St. Chamberlain. Wegbereiter Deutschen Christentums series. Weimar: Verlag Deutsche Christen, 1940 .

Grace, James. "Basil Hall Chamberlain; Born 1850, died February 15, 1935." Japan Society, Transactions and Proceedings. [Loridon] (1935): 46.

Grierson, H. J. C. Carlyle \& Hitler: The Adamson Lecture in the University of Manchester December 1930 with some additions and modifications. Cambridge: Cambridge University Press, 1933. 
Gurney, Edmund. "Wagner and Wagnerism." The Nineteenth Century, XIII, March 1883, pp. 434-452.

Gutman, Robert W. Richard Wagner: The Man, His Mind, and His Music. New York: Harcourt, Brace \& World, Inc., 1968.

Hall, Basil. "The First Englishman Napoleon Ever Saw." Introduction by Sophy Hall. The Nineteenth Century. October, 1912. pp. 718-731.

Hampson, Norman. The Enlightenment. The Pelican History of European Thuight, vol. 4. Baltimore: Penguin Books, 1968.

- The First European Revolution 1776-1815. New York: Harcourt, Brace \& World, Inc., 1969.

Heer, Friedrich. Gottes Erste Liebe: 2000 Jahre Judentum Und Christentum Genesis Des Oesterreichischen Katholiken Adolf Hitler. Munich and Esslingen: Bechtle, 1967.

Heller, Erich. The Disinherited Mind. 4th ed. Cleveland \& New York: The World Publishing Company, 1959; reprint ed. Cleveland \& New York: The World Publishing Company, 1965.

Herzstein, Robert Edwin. "Richard Wagner at the Crossroads of German Anti-Semitism 1848-1933. A Re-Interpretation." Zeitschrift fllr. die Geschichte der Juden IV Jahrgang Nr. 2/3 (1967): 119-140.

. "The Tragedy of Richard Wagner." Arts and Sciences [New York University ] (Winter 1965): 25-28.

- "The Wagnerian Ethos In German History, 1848-1933: A Reinterpretation of Richard Wagner's Mistorical Significance." Ph.D. dissertation, New York University, 1964.

Hess, M. Whitcomb. "Houston Stewart Chamberlain: Prophet of Nazisn." Cormonweal, 5 May, 1939, pp. 37-39.

Hitler, Adolf. H1tler's Secret Conversations, 1941-1944. Translated by Norman Cameron. 1953; New York: Octagon Books, 1972.

- Secret Conversations with Hitler; The Two Newly-Discovered 1931 Interviews. Edited by Edouard Callc. Translated by Richard Barry. New York: The John Day Company, 1971.

Hollinrake, Roger. "Nietzsche, Wagner and Ernest Newman." Music and Letters 41 \#3 (July 1960): 245-256.

Holmes, Colin. "Houston Stewart Chanberlain in Great Britain." Wiener Library Bulletin 24 \#2 (1970): 31-36. 
Humboldt, Wilhelm von. Humanist Without Portfolio: An Anthology of The Hitings of Wilhelm von Humboldt. Edited by Marlanne Cowan. Detroit: Wayne State University Press, 1963.

Jacobs, Robert I. Wagner. Iondon: Alan Ross, 1966.

Joll, James, Three Intellectuals In Polit1cs; Blum, Rathenau, Marinetti. New York: Harper Colophon Books, 1960.

Kaltenbrumer, Gerd-Klaus. "Houston Stewart Chamberlain - the Most Germanic of Germans." Wiener Iibrary Bulletin (Winter 67/68): 6-12.

Keyserling, Hermann Graf. Reise Durch die Zeit. Innsbruck: Verlag Der Palme, 1948.

Kniese, Julius. Der Kampf zweier Welten um das Bayreuther Erbe: Julius Knieses Tagebuchblutter aus dem Jahre 1883. Edited by Julle Kniese. Leipzig: Theodor Weicher, 1931.

Kohn, Hans. "The eve of German Nationalism." Journal of the History of Ideas XII \#I (January 1951): 256-274.

- The Mind of Germany; The Education of a Nation. New York: Charles Scribner's Sons, 1960.

Kraft, Zdenko von. Der Sohn: Slegfried Wagners Leben und Umwelt. Graz and Stuttgart: Ieopold Stocker, 1969.

Krieger, Leonard. The German idea of freedom: history of a political tradition. 1957; Chicago: University of Chicago Press, 1972.

- Kings And Philosophers 1689-1789. New York: W. W. Norton \& Company, Inc., 1970.

Kuehnelt-Leddihn, Erik R. von. "The Bohemian Background of German National Socialism: The D. A. P., D. N. S. A. P., and the N. S. D. A. P." Journal of the History of Ideas IX \#I (January 1948): 339-371.

Lange, Frederick Albert. The History of Materialism: And Criticism of Its Present Importance. Translated by Ernest Chester Thomas. Introduction by Bertrand Russell. Iondon: Routledge \& Kegan Paul Ltd, 1950.

Lebovics, Herman. Social Conservatism and the Middle Classes in Germany, 1914-1933. Princeton, New Jersey : Princeton University Press, 1969.

Levin, Gerald. "Shaw, Butler and Kant." Philological Quarterly. (Apri1 1973): 142-197. 
I11ge, Frederic. The Abuse of Learning; The failure of the German University. New York: The Macmillan Company, 1948.

Magee, Bryan. Aspects of Wagner. Iondon: Alan Ross, 1966.

Mann, Thomas. "Sufferings and greatness of Richard Wagner." Essays of Three Decades. Translated by H. T. Lowe-Porter. New York: Alfred A. Knopf, 1948. pp. 307-352.

McGrath, William J. Dionysian Art and Populist Politics in Austria. New Haven: Yale University Press, 1974.

Meyer, Hugo. Houston Stewart Chamberlain als vblkischer Denker. Munich: Bruckmann, 1939.

Mosse, George L. The Crisis of German Ideology: Origins of The Third Reich. New York: Grosset \& Dunlap, 1964.

- Germans And Jews: The Right, The Left, And The Search For A "ThIrd Force" In PreNazi Germany. New York: Howard Fertig, 1970 .

- The Nationalization of the Masses: Political Symbolism and Mass Movements in Germany from the Napoleonic Wars Through The Third Reich. New York: Howard Fertig, 1975.

Muller-Sturmheim, E. "From Kant to Hitler." Quarterly Review, January 1941, pp. 80-89.

Musil, Robert. Der Mann Ohne Eigenschaften. Hamburg: Rohwohlt, 1952.

Neue Deutsche Biographie; Herausgegeben von der Historischen Kommission bei der Bayrischen Akademie der Wissenschaften, 3rd. vol. Berlin: Duncker \& Humblot, 1957. "Chamberlain, Houston Stewart, Schriftsteller," by Otto Graf zu Stolberg-Warnigerode.

Neumann, Alfred. "The earliest use of the term Gesamtkunstwerk." Philological Quarterly Vol. XXXV 2 (April 1956): 191-193.

"A New View Of Kant." The Spectator, August 22, 1914, pp. 269-270.

Newman, Ernest. The Life of Richard Wagner. 4 vols. New York: Alfred A. Knopf, 1933-1946.

Nielsen, Willi. Der Lebens- und Gestaltbegriff bei Houston Stewart, Chamberlain: Eine Untersuchung seiner Lebenslehre unter besonderer Bertlcksichtigung ihre geisteswissenscharttichen Grundlagen und Beziehungen. Inaugural Dissertation for KIel University in Philosophy. Kiel: Schmidt and Klaunig, 1938. 
Nietzsche, Friedrich. The Birth of Tragedy and The Case of Wagner. Translated by Walter Kaufmann. New York: Vintage Books, 1967.

- The Portable Nietzsche. Selected works translated by Walter Kaufmann. New York: Viking Press, 1954.

Nolte, Ernst. Three Faces of Fascism: Action Francaise, Italian Fascism, National Socialism. Translated by Leila Vennewitz. Munich: Piper, 1963; New York: Mentor Books, 1969.

Nordau, Max. Degeneration. 2nd ed. London: William Heinemann, 1920.

Payne, William Morton. "Richard Wagner and the Bayreuth Idea." Dial, I November, 1897, pp. 242-247.

Peudert, Fritz. "Chamberlain und Nietzsche." Nationalsozialistische Monatshefte vol. 49, April 1934, pp. 299-305.

Porter, Andrew. "Wagner And 'The Ring. '" Seattle, Washington Opera Association program Wagner's "The Ring of the Nibelung" (July 1975) pp. 18-19.

Pretzsch, Paul, ed. Bayreuther Festspielfuhrer: 1928. Bayreuth: Georg Niehrenheim, 1928.

Raphael, Robert. Richard Wagner. New York: Trayne Publishers, Inc., 1969.

Redesdale (Mitford), Lord. Review of The Foundations of the Nineteenth Century, by Houston Stewart Chamberlain. Edinburgh Review, January 1914, pp. 81 and 90.

Review of Richard Wagner, by Houston Stewart Chamberlain. The Critic, 8 January 1898, p. 23.

Review of Richard Wagner, by Houston Stewart Chamberlain. The Spectator, 26 March 1898, p. 453.

Rie, Robert. "Nietzsche and After." Journal of the History of Ideas 13 (June 1952): 349-370.

Ringer, Fritz K. The Decline of The German Mandarins: The German Academic Community, 1890-1933. Cambridge, Massachusetts: Harvard University Press, 1969.

Robertson, J. M. "Herr Chamberlain and the War." Contemporary Review, September 1915, pp. 296-308.

Roosevelt, Theodore and Abbott, Lyman. Review of The Foundations of the Nineteenth Century, by Houston Stewart Chamberlain. The out look, 29 July 1911, pp. 728-734. 
Rosenberg, Alfred. Houston Stewart Chamberlain als Verkdlnder und Begrunder einer deutschen Zukunft. Munich: Bruckmann, 1927.

Schmidt, Ferdinand Jakob. Review of Immanuel Kant, by Houston Stewart Chamberlain. Preussische Jahrbucher, September 1906, pp. 531-537.

Schroeder, Leopold von. Houston Stewart Chamberlain: Ein Abriss seines Lebens, auf Grund eigener Mitteilungen. Munich: J. F. Lehmann, 1918.

- Die Vollendung des arischen Mysteriums in Bayreuth. Munich: J. F. Iehmann, 1911 .

Schller, Winifred. Der Bayreuther Kreis Von Seiner Entstehung Bis Zum Ausgang Der Wilhelminischen Ara: Wagnerkult Und Kulturreform Im Geiste VBIkischer Weltanschauung. Minster: Aschendorff, 1971.

Seilliere, Ernest. Houston-Stewart Chamberlain: Le plus récent philosophe du Pangermanisme mystique. Paris: La Renaissance du Livre, 1917.

Shanahan, E. T. "Completing the Reformation." Catholic World, I May 1914, pp. 433-445.

"Shrieking all the way." Review of Nancy Mitford: A Memoir, by Harold Acton. Newsweek, 3 May 1976, pp. 91-94.

Skeiton, Geoffrey. Wagner Ai Bayreuth, Experiment And Tradition. New York: George Braziller, 1965.

- Wieland Wagner: The Positive Skeptic. New York: St. Mart in's Press, 197.

Siegfried, Walther. Frau Cosima Wagner; Studie eines Lebens. Stuttgart: Union Deutsche Verlagsgeselischaft, 1930.

Snyder, Louis L. The Idea of Racialism; Its Meaning And History. New York: Van Nostrand Rheinhold Company, 1962.

Sokoloff, Alice Hunt. Cosima Wagner: An Extraordinary Daughter of Franz Liszt. New York: Dodd, Mead \& Co., 1969.

Spengler, Oswald. Selected Essays, edted by Donald 0. White. Chicago: Henry Regnery Company, 1967.

Spitzer, Leo. "Anti-Chamberlain: Betrachtungen eines Linguisten Uber Houston stewart Chamberlains "Kriegsaufshtze" und die Sprachbewertung im allgemeinen." Wahrend der Militardienstzeit, Aufsatze von Dz. Dr. Leo Spitzer. Le1pzig: 0. R. Risland, 1918. 
Steed, Wickham. "The Iegend Behind Hitlerism." Goldenbook Magazine, August 1934, pp. 186-191.

Stewart, William Kilbourne. "A Humanized Kant." Dial, I November 1914, pp. 333-335

Tolischus, Otto D. "Wagner: Clue to Hitler." New York Times Magazine, 25 February 1940, pp. 6-7.

Tolstoy, Lyof. The Novels And Works Of Tolstoy. Vol. XIX: The Kingdom Of God Is Within You. New York; Charles Scribner's Sons, 1899.

- The Novels And Works Of Tolstoy. Vol. XIX: What Is Art? New York: Charles Scribner's Sons, 1899.

Tuchman, Barbara W. The Proud Tower: A Portrait of the World Before the War 1890-1914. New York: The Macmilian Company, 1962.

Vier’ck, Peter. Metapolitics: The Roots of the Nazi Mind. New York: Aifred A. Knopf, Inc, 1941; revised and enlarged edition [of Metapolitics: From The Romantics To Hitler] New York: Capricorn Books, 1961.

V81kischer Beobachter. Issues January-March, 1927.

Vollrath, Wilhelm. Th. Carlyle und H. St. Chamberlain, zwei freunde Deutschlands. Munich: J. F. Lehmann, 1935.

- Vom Rittertum der Theologie; Hart am Wort. Leipzig: Dorffrling and Franke, 1934.

Wagner, Friedelind and Cooper, Page. Heritage of Fire: The Story of Richard Wagner's Granddaughter. New York: Harper \& Brothers Publishers, 1945.

Wagner, Richard: "Ausfthrungen zu 'Religion und Kunst:' Heldenthum und . Christenthum." Bayreuther Bld dtter; Monatschrift des Bayreuther. Patronatvereines, Neuntes Stllch, 1881.

- Judaism In Music, Being The Original Essay Together With The Later Supplement. Translated by Edwin Evans. New York: Charles Scribner's Sons, 1940.

- Richard Wagner's Letters to August Roeckel. Translated by Eleanor C. Sellar. Introductory essay ig Houston Stewart Chamberlain. Bristol: J. W. Arrowsmith, n.d. [before 1900].

- Wagner: On Music And Drama: A Compendium of Richard Wagner's Prose Works, Arranged by Albert Goldman. Translated by Ashton Ellis. New York: E. P. Dutton \& Co., Inc., 1964. 
Wagner, Siegfried. Erinnerungen. Stuttgart: J. Engelhorn, 1923.

Weigand, Hermann J. "Nietzsche's Dionysus-Ariadne Fixation." Germanic Review (March 1973): 99-116.

Willey, Thomas Edrmund, "Back to Kant: The Revival Of Kantian Idealism in Germany 1870-1914." Ph.D. dissertation, Yale University, 1965.

"Winifred Wagner: Guilty." Newsweek, 14 July 1947, p. 44.

White, Hayden. Metahistory: The Historical Imagination in NineteenthCentury Europe. Baltimore \& London: The Johns Hopkins University Press, 1973.

Zuckermann, Elliott. The First Hundred Years of Wagner's Tristan. New York: Columbia University Press, 1964. 